
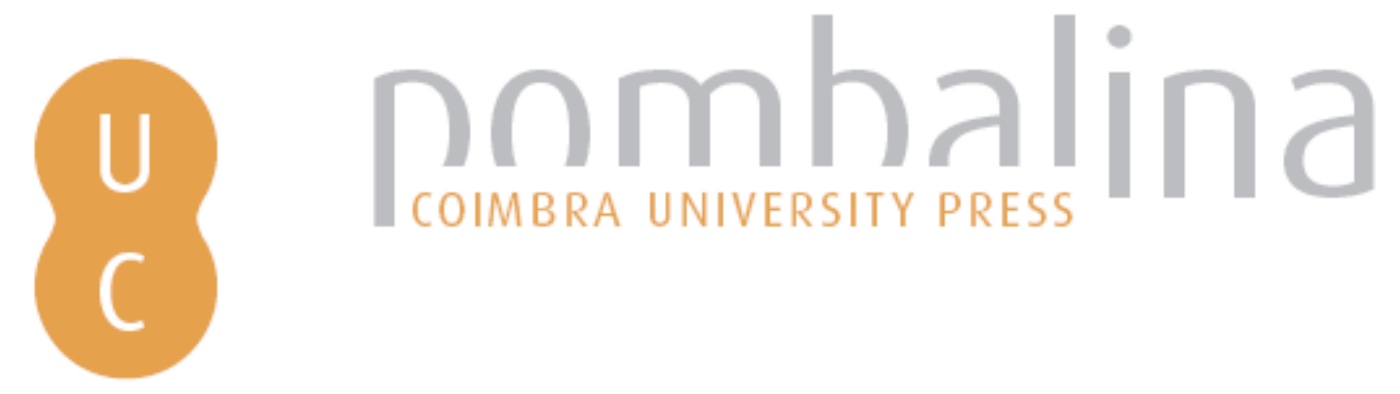

\title{
Relato de discurso e fantasias do Portugal contemporâneo
}

Autor(es): $\quad$ Figueiredo, Paula Eduarda Moreira

Publicado por: Imprensa da Universidade de Coimbra

URL

persistente: URI:http://hdl.handle.net/10316.2/32867

DOI: $\quad$ DOI:http://dx.doi.org/10.14195/978-989-26-0707-8

Accessed : $\quad$ 26-Apr-2023 10:52:52

A navegação consulta e descarregamento dos títulos inseridos nas Bibliotecas Digitais UC Digitalis, UC Pombalina e UC Impactum, pressupõem a aceitação plena e sem reservas dos Termos e Condições de Uso destas Bibliotecas Digitais, disponíveis em https://digitalis.uc.pt/pt-pt/termos.

Conforme exposto nos referidos Termos e Condições de Uso, o descarregamento de títulos de acesso restrito requer uma licença válida de autorização devendo o utilizador aceder ao(s) documento(s) a partir de um endereço de IP da instituição detentora da supramencionada licença.

Ao utilizador é apenas permitido o descarregamento para uso pessoal, pelo que o emprego do(s) título(s) descarregado(s) para outro fim, designadamente comercial, carece de autorização do respetivo autor ou editor da obra.

Na medida em que todas as obras da UC Digitalis se encontram protegidas pelo Código do Direito de Autor e Direitos Conexos e demais legislação aplicável, toda a cópia, parcial ou total, deste documento, nos casos em que é legalmente admitida, deverá conter ou fazer-se acompanhar por este aviso. 
RELATO

DE DISCURSO

E FANTASIAS

DO PORTUGAL

CONTEMPORÂNEO
IMPRENSA DA

UNIVERSIDADE

DE COIMBRA

COIMBRA

UNIVERSITY

PRESS

PAULA

EDUARDA

MOREIRA

FIGUEIREDO 
(Página deixada propositadamente em branco) 
竞

$\frac{\mathrm{I}}{\mathrm{U}}$ 
EDIÇÃo

Imprensa da Universidade de Coimbra Email: imprensa@uc.pt

URL: http//www.uc.pt/imprensa_uc

Vendas online: http://livrariadaimprensa.uc.pt

COORDENAÇÃO EDITORIAL

Imprensa da Universidade de Coimbra

CONCEÇÃO GRÁFICA

António Barros

IMAGEM DA CAPA

António Barros

PRÉ-IMPRESS ÃO

Nelson Ferreira

DOI

http://dx.doi.org/10.14195/978-989-26-0707-8

ISBN DIGITAL

978-989-26-0707-8 

RELATO
IMPRENSA DA
UNIVERSIDADE
DE COIMBRA
DE DISCURSO
UNIVERSITY
PRESS
E FANTASIAS
DO PORTUGAL
CONTEMPORÂNEO

PAULA

EDUARDA

MOREIRA

FIGUEIREDO 
(Página deixada propositadamente em branco) 


\section{S U M Á R I O}

INTRODUÇÃO

1. HETEROgENEIDAdE ENUNCIATIVA NA LÍNGUA E NO DISCURSO 23

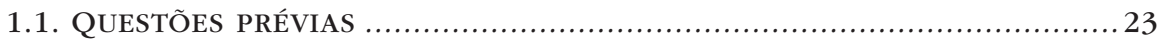

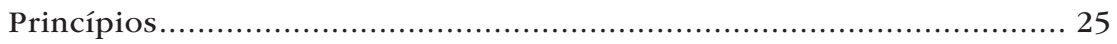

Conceitos. ....................................................................... 30

Interrogações. .............................................................. 34

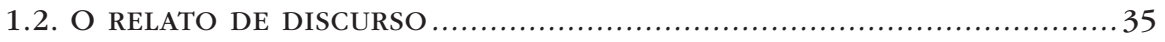

1.2.1. Perspetivas de análise .............................................. 35

1.2.2. Formas prototípicas de relato de discurso ......................... 40

1.2.3. Outras formas de citar palavras .................................. 54

1.3. O RElato de discurso nos PRogramas de ENSINO DE PORTUguês E NAS GRAMÁTICAS ................................................... 58

2. LITERATURA E CONSTRUÇÃO DE IMAGENS IDENTITÁRIAS ....................... 69

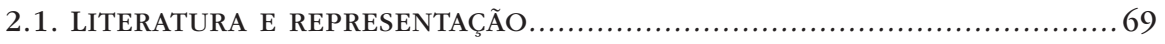

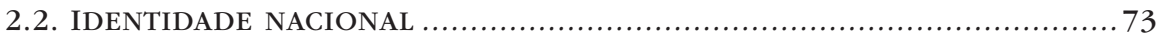

2.3. ESTEREÓTIPO E REPRESENTAÇÃO SOCIAL .................................76

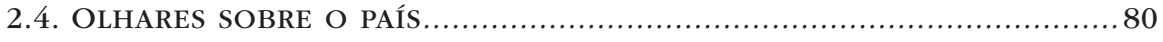

Imagens do Portugal contemporâneo ..................................... 80

Mário de Carvalho em discurso direto................................... 90 
3. MOdulações de portugal em fantasia para doIs Coronéis e Uma

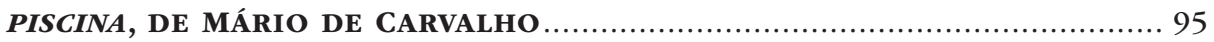

3.1. OCORRÊNCIAS E FUNCIONALIDADES DO RD NO ROMANCE ................ 102

Tipos de relato de discurso .................................................... 102

Vozes que predominam................................................. 103

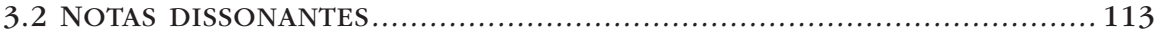

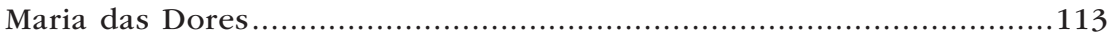

Januário... ........................................................................ 116

Os claquistas................................................................... 120

3.3. VARIAÇÕES SOBRE MOFINA MENDES ..................................... 122

3.4. ACORDES DE UM PAÍ́S TAGARELA ............................................. 125

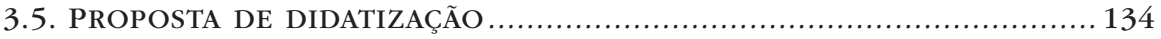

3.5.1. Alguns pressupostos teóricos .......................................134

3.5.2. Abordagem do RD na aula de PLE de nível C1 ......................140

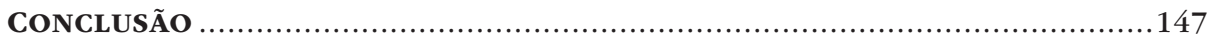

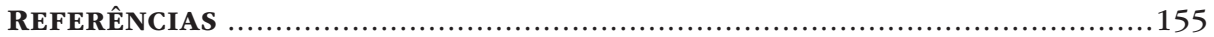

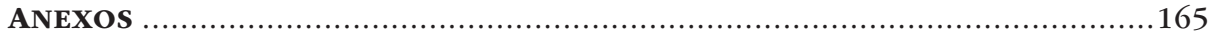

ANEXO 1 - TEIA de PERSONAgENS - FANTASIA PARA DOIS CORONÉIS E UMA PISCINA, DE MÁRIO DE CARVALHO (2003)................................ 167

ANEXO 2 - O RELATO DE DISCURSO NOS PROGRAMAS OFICIAIS DE LÍNGUA PORTUGUESA/PORTUGUÊS ....................................................... 168

ANEXo 3 - O RElato de Discurso nos programas do CURSO ANUAL DE PORTUGUÊS PARA ESTRANGEIROS (2010/2011).......................... 172

ANEXO 4 - O RELATO DE DISCURSO EM FANTASIA PARA DOIS CORONÉIS E UMA PISCINA, DE MÁRIO DE CARVALHO.......................................... 174

Tabela 1 - Tipo de relato de discurso ....................................174

Tabela 2 - Número de vozes diferentes por tipo de RD .................174

Tabela 3 - Vozes que predominam no romance ............................174

Tabela 4 - Discurso direto...................................................175

Tabela 5 - Discurso indireto livre....................................... 175 
Tabela 6 - Reprodução de palavras no discurso do narrador.............176

Tabela 7 - Discurso indireto..................................................176

Tabela 8 - Modo híbrido ........................................................176

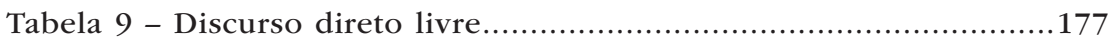

ANEXO 5 - O MODO HÍBRIDO EM FANTASIA PARA DOIS CORONÉIS E UMA

PISCINA, DE MÁRIO DE CARVALHO (2003)................................. 178

Tabela 1 - Ocorrências em modo híbrido ...................................178

Tabela 2 - Ocorrências e características do modo híbrido no romance .....178 ANEXO 6 -VERBOS INTRODUTORES POR TIPO DE RD EM FANTASIA PARA DOIS CORONÉIS E UMA PISCINA, DE MÁRIO DE CARVALHO (2003) .................. 182

Tabela 1 - Verbos introdutores de discurso direto .........................182

Tabela 2 - Verbos introdutores de discurso indireto livre .................183

Tabela 3 - Verbos introdutores na reprodução de palavras no discurso do narrador ........................................................ 183

Tabela 4 - Verbos introdutores de discurso indireto .........................183

Tabela 5 - Verbos introdutores de modo híbrido ...........................184

Tabela 6 - Verbos introdutores de discurso direto livre ....................184

ANEXO 7 - VERBOS INTRODUTORES POR PERSONAGEM EM FANTASIA PARA

DOIS CORONÉIS E UMA PISCINA, DE MÁRIO DE CARVALHO (2003) .......... 185

Tabela 1 - Verbos introdutores de RD, por personagem ....................185

Tabela 2 - Verbos/combinatórias da isotopia do ruído, por personagem ..... 185

ANEXO 8 - FALAS DE MARIA DAS DORES .................................... 187

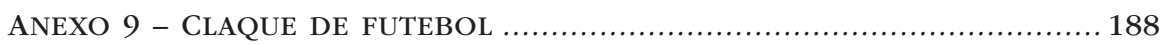

Tabela 1 - Transcrições do romance........................................... 188

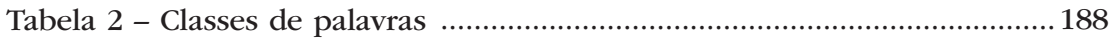

ANEXO 10 - AS COMPETÊNCIAS DO NÍVEL C1 DE PROFICIÊNCIA NO QUADRO

EUROPEU COMUM DE REFERÊNCIA PARA AS LÍNGUAS ....................... 190

Tabela 1 - Grelha para autoavaliação ....................................... 190

Tabela 2 - Aspectos qualitativos do uso oral da linguagem ..............191

Tabela 3 - Produção escrita .................................................. 191

Tabela 4 - Compreensão oral ................................................... 192

Tabela 5 - Compreensão escrita (leitura) ................................... 192

Tabela 6 - Competências linguísticas ...................................... 193 
Tabela 7 - Receção de audiovisual .........................................194

Tabela 8 - Estratégias gerais de receção .....................................194

ANEXO 11 - ROTEIRO DE UNIDADE DIDÁTICA ................................... 195

ANEXO 12 - FICHA DE TRABALHO 1 - RELATO DE DISCURSO ................... 198 ANEXo 13 - Ficha de TRABAlho 2 - Verbos introdutores de RElATO DE

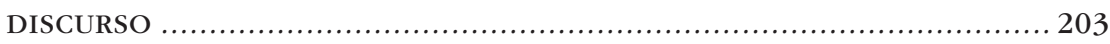


À memória de meu pai.

À minha mãe e ao Ricardo, meus pilares. 
(Página deixada propositadamente em branco) 


\section{R E S U M O}

Este trabalho ${ }^{1}$ tem como base teórica a Linguística da enunciação/ textual e ancora-se em instrumentos de análise literária que relevam da construção de imagens identitárias. O seu objetivo foi estudar o papel que os mecanismos de reprodução de discurso no discurso desempenham na textualização da tese que o narrador de Fantasia para dois coronéis e uma piscina, de Mário de Carvalho, enuncia nas primeiras páginas desta obra de 2003: Portugal «fala, fala, desunha-se a falar» (p. 11), esgota-se numa vozearia omnipresente e inconsequente.

Numa primeira fase, é feita a descrição enunciativo-pragmática das formas prototípicas de relato de discurso (discurso direto, discurso indireto e discurso indireto livre), havendo ainda lugar para uma referência sucinta ao discurso direto livre e a formas periféricas. Após a dilucidação dos conceitos operativos essenciais para o estudo das questões identitárias, são analisados a presença, o peso e as características das vozes das personagens mais significativas do romance. Finalmente, é apresentada uma proposta de didatização, tendo como público-alvo estudantes universitários de Português Língua Estrangeira de nível C1 de proficiência.

A pesquisa permitiu concluir que, neste “cronovelema» (p. 34), se verifica uma homologia entre forma e conteúdo: a explosão de vozes que satura, em discurso direto, um romance estruturalmente estilhaçado

\footnotetext{
1 Trabalho apresentado como requisito parcial à obtenção do grau de Mestre em Letras - Área de Português como Língua Estrangeira e Língua Segunda: Linguística Aplicada, sob a orientação das Professoras Doutoras Ana Cristina Macário Lopes e Ana Maria Machado, na Faculdade de Letras da Universidade de Coimbra, em 2011.
} 
ilustra o aturdimento em que se compraz um país verborreico e néscio - e nada preocupado por sê-lo.

Palavras-chave: Relato de discurso, imagens identitárias, texto literário, Mário de Carvalho, Português Língua Estrangeira. 


\section{A B R E VIATURAS}

CAPE - Curso Anual de Português para Estrangeiros

DD - Discurso direto

DDL - Discurso direto livre

DI - Discurso indireto

DIL - Discurso indireto livre

DT - Dicionário Terminológico

EB - Ensino Básico

ES - Ensino Secundário

FLUC - Faculdade de Letras da Universidade de Coimbra

L1 - Língua 1

L2 - Língua 2

LE - Língua Estrangeira

LM - Língua Materna

LP - Língua Portuguesa

LS - Língua Segunda

MC - Mário de Carvalho

ME - Ministério da Educação

NPPEB - Novos Programas de Português do Ensino Básico

PLE - Português Língua Estrangeira

PLM - Português Língua Materna

PLNM - Português Língua Não Materna

QECRL - Quadro europeu comum de referência para as línguas

RD - Relato de discurso

UC - Universidade de Coimbra 
(Página deixada propositadamente em branco) 


\section{N T R O D U Ç Ã O}

As palavras, como os seres vivos, nascem de vocábulos anteriores, desenvolvem-se e fatalmente morrem. As mais afortunadas reproduzem-se.

José Eduardo Agualusa, Milagrário pessoal

Inserir palavras de outrem no nosso discurso ou reconhecer, num texto oral ou escrito, proferido ou redigido por alguém, o que outros disseram/escreveram anteriormente é uma prática a que todos - como falantes/ouvintes/leitores - recorremos, natural e frequentemente, sem nos apercebermos nem da pluralidade nem da complexidade das questões que relevam desses mecanismos de citação. Sempre que isso acontece, multiplica-se a origo enunciadora e, consequentemente, ecoa(m) outra(s) voz(es) no discurso, plasmando-se no texto aquilo a que se chama relato de discurso (RD).

A constatação da possibilidade dessa heterogeneidade enunciativa abre caminho a várias interrogações: de que forma reconhecer e delimitar os diferentes enunciadores? Qual a relevância do contexto de comunicação para interpretar o que é dito? De que modo é concretizada a reutilização dos recursos linguísticos? Trata-se de práticas involuntárias ou de opções ponderadas? Neste último caso, que intenção preside a essas escolhas e quais as (eventuais) implicações na interação com o(s) outro(s)? Equacionando esta problemática num outro patamar, tendo em conta a minha formação inicial e a minha atividade profissional, qual a relevância do relato de palavras nos textos estudados e produzidos em contexto 
de aula, no âmbito do ensino e da aprendizagem de uma língua viva? Ainda tendo como referente a prática pedagógica, como abordar essa estratégia discursiva quando se leciona uma língua a discentes não-nativos? Conseguirão esses aprendentes identificar nos textos os diferentes enunciadores e compreender as implicações dessa presença múltipla? Como ensinar o RD se o professor não conhecer as línguas maternas dos alunos ou o domínio que delas possuir for manifestamente insuficiente? As línguas naturais, sobretudo as de famílias distintas, funcionam de forma diversa e o estudo comparativo das respetivas estruturas linguísticas e pragmáticas - metodologia muito produtiva no ensino formal de uma língua estrangeira (LE) - pode revelar-se inexequível. Que recursos pedagógico-didáticos podem e devem ser mobilizados pelo docente para orientar os seus alunos, nativos ou estrangeiros, na identificação, compreensão, interpretação e apropriação dessa ferramenta comunicativa, para que dela consigam fazer uso de forma linguística e pragmaticamente adequada, quer como recetores quer como produtores de discurso?

Enquanto professora de Português Língua Materna (PLM) do Ensino Básico (EB), nestes últimos anos da minha prática docente e dando cumprimento às orientações programáticas emanadas do Ministério da Educação (ME), lecionei o discurso direto (DD) e o discurso indireto (DI) - a partir do $9^{\circ}$ ano, também o discurso indireto livre (DIL) -, bem como as regras de citação. Ensinei aos meus alunos a distinguir essas diferentes formas de integrar num discurso palavras de outro(s), a interpretá-las e a produzir frases corretas e apropriadas, onde estivessem presentes quer o DD quer o DI, aplicando as regras comummente explanadas nas gramáticas e nos manuais escolares e resolvendo exercícios essencialmente de natureza transformacional. Pude constatar, com frequência, que muitos discentes têm mais dificuldade em aplicar as regras gramaticais tornadas explícitas do que em utilizar o RD nas suas interações verbais quotidianas.

Foi apenas ao elaborar este trabalho, quando me imaginei a assumir o papel de professora de Português Língua Estrangeira (PLE), durante a pesquisa teórica e perante o desafio inerente de conceber estratégias e materiais pedagógicos para a abordagem do RD com alunos não-nativos, que me confrontei com dificuldades insuspeitadas e com a necessidade 
de perspetivar de forma diversa este conteúdo programático - simples apenas na aparência -, sob pena de perpetuar o que percebi ser um tratamento redutor e de escassa produtividade pedagógica. Não obstante a complexidade da questão - que tem de ser filtrada antes de apresentada nas aulas, uma vez que o estudo de cada matéria deve sempre adequar-se ao público-alvo -, considero agora que uma reflexão rigorosa sobre o RD é uma etapa essencial na formação metalinguística de qualquer docente de Português, L1 ou L2².

Para o estudo do(s) discurso(s) no(s) discurso(s), assumi sem hesitação como ponto de partida da minha investigação a conciliação entre Linguística e Literatura. Não apenas por gosto pessoal, mas igualmente pela convicção de que as virtualidades expressivas dos textos literários rasgam horizontes e, graças ao jogo mutualista que implicam na construção de sentidos (Simões, 2006: 80), constituem ganhos inestimáveis quando se estuda uma língua, seja como falante nativo seja como aprendente estrangeiro. Para além do mais, o relato de palavras tem sido uma área de investigação onde esses dois campos de estudo se têm intersetado. Por isso, a plurivocalidade discursiva do texto literário e o consequente desafio interpretativo que ele lança são aspetos que me seduzem, quer enquanto leitora quer como docente.

Perspetivando como público-alvo virtual jovens estudantes não portugueses a frequentar a Universidade de Coimbra (UC), considerei relevante, como contributo para a compreensão do mundo em que estão temporariamente integrados, vivendo e estudando, procurar em textos de autores portugueses atuais modos de representação identitária construídos através da reprodução de discurso. Propus-me, assim, conjugar a abordagem linguística com a literária, estudando os mecanismos de configuração

\footnotetext{
2 Trata-se de designações que dizem respeito à aquisição e aprendizagem de línguas por um indivíduo. L1 é a língua que se adquire na infância (habitualmente designada como Língua Materna - LM); L2 é uma língua que é aprendida depois e que pode ser uma LS Língua Segunda, aquela que um não-nativo aprende no território onde ela tem uma função política, social e cultural e cujo domínio é essencial para que, aí vivendo, se possa integrar e ter um papel ativo como cidadão - ou uma LE - aquela que é objeto de ensino formal, seja no território onde é usada como língua oficial seja noutro espaço físico (Leiria, 2004; Galisson \& Coste, 1983: 442-3). Em Portugal, nas escolas básicas e secundárias, adotou-se a designação de Português Língua Não Materna (PLNM) para o ensino formal de português LS a alunos não-nativos. Neste trabalho, o campo de referência é o de Português L2 como LE.
} 
de imagens nacionais através das vozes que se entrelaçam numa trama ficcional, relevando o seu papel na construção de uma determinada imagem do Portugal contemporâneo. Como horizonte sempre presente, uma abordagem pedagógica destinada a esses alunos universitários de PLE.

Foram duas as questões que espoletaram a pesquisa e me conduziram à escolha do corpus a analisar: (1) a que estruturas linguístico-pragmáticas do RD o narrador da obra literária lança mão para caracterizar as suas personagens? (2) se a reprodução de palavras e/ou pensamentos assume particular relevância na configuração dos carateres ficcionais e traduz a empatia ou o distanciamento do narrador em relação a elas (Reis \& Lopes, 2002: 320-1), em que medida pode o leitor, no processo de construção de sentidos que o ato de ler convoca, reconstruir uma determinada cosmovisão do narrador, a partir do microcosmos que ele recria?

Fantasia para dois coronéis e uma piscina ${ }^{3}$ foi o ponto de partida para a reflexão, análise textual e posterior proposta de didatização. Nesse texto de Mário de Carvalho (n. Lisboa, 1944), a explosão de loquacidade anunciada/denunciada logo nas primeiras linhas - «Assola o país uma pulsão coloquial que põe toda a gente em estado frenético de tagarelice, numa multiplicação ansiosa de duos, trios, ensembles, coros» (11) - é o esteio do puzzle social português que o narrador se propõe construir nas duzentas e vinte e sete páginas deste "cronovelema", subgénero narrativo gizado pelo escritor, polifónico quer na forma quer no conteúdo ${ }^{4}$. Para além da imediata homologia entre o romance e Portugal, sugerida pela capa da edição de 2003 da Caminho - uma piscina retangular, cujos contornos são os do país 5

3 Mário de Carvalho (2003). Fantasia para dois coronéis e uma piscina. Lisboa: Caminho. Todas as referências à obra, que será abreviada como Fantasia..., remeterão para esta edição. As páginas das citações serão indicadas entre parênteses.

4 Cf. infra ponto 3.

5 Imagem da capa disponível no site de Mário de Carvalho: http://www.mariodecarvalho. com/obras. Desconheço se a instalação "Portugal a Banhos», concebida pela artista plástica Joana Vasconcelos no âmbito das comemorações do centenário da República Portuguesa e exposta na Praça do Comércio, em Lisboa, se inspirou na capa da Caminho, cujo design gráfico foi da responsabilidade de José Serrão. Todavia, quem conhece essa edição do romance não pode deixar de aproximar estas duas obras de áreas criativas tão diversas. A imagem de "Portugal a Banhos» está disponível em http://www.flickr.com/photos/miguelmalaquias/sets/72157625385878206/detail/. 
-, concerta-se, logo na abertura, uma espécie de tese ${ }^{6}$ : no início do novo milénio, Portugal tornou-se uma nação em que a vozearia ensurdecedora se disseminou, multiplicando a vacuidade e paralisando a criatividade. Essa prolixidade - «Fala-se, fala-se, fala-se, em todos os sotaques, em todos os sons e decibéis, em todos os azimutes. O país fala, fala, desunha-se a falar, e pouco do que diz tem o menor interesse. [...] O país quer é aturdir-se. E a tagarelice é o meio de aturdimento mais à mão" (11) - é materializada através da avalanche verborreica de uma plêiade de personagens que, protagonizando inesperadas interseções, urdem no romance a tessitura humana de um certo Portugal dos começos do século XXI. Os discursos torrenciais que escoram Fantasia... incitaram-me a tentar perceber se e de que modo o RD é uma estratégia discursiva que ilustra um axioma e como se posiciona o narrador face a esse novo traço que parece estar a reconfigurar a nossa identidade nacional.

Não sendo de todo um texto fácil, é um romance desafiante, que abre um campo de análise que reputo de grande relevância para jovens estrangeiros que escolheram Portugal para estudar a sua língua e cultura; simultaneamente, é uma obra muito divertida, graças à qual os alunos poderão experimentar o prazer de descobrir um dos grandes escritores vivos da nossa literatura contemporânea; tratando-se de um texto relativamente recente, permite ainda ter uma visão atual do país e, ao mesmo tempo, aferir o grau de fidelidade de Mário de Carvalho (MC) às normas da reprodução do discurso no discurso, uma vez que uma das prerrogativas de que se reclama o romance pós-moderno - qualificativo atribuído a Fantasia... por vários críticos ${ }^{7}$ - é a da implosão das regras.

Não posso deixar de referir a pluralidade de discursos que ressoam no romance, para além do "falajar» instrínseco dos portugueses (Fantasia... 12), cujas idiossincrasias o romancista vai modelando no seu texto. Nele dialogam inúmeras vozes e multiplicam-se as referências

$6 \mathrm{Na}$ véspera da colocação à venda do romance, o escritor reconhece o seguinte: «O número de páginas do livro dedicadas à tagarelice nacional era originalmente muito superior (na verdade, era quase um ensaio), mas acabei por o encurtar por uma questão de economia do romance» (M. João Martins, 2003: 10).

${ }^{7}$ Cf. infra ponto 3. 
de diversa índole, orquestrando uma inesgotável fantasia (no sentido musical do termo), ostensivamente anunciada no título e muitas vezes autorreferencial, tão ao gosto de $\mathrm{MC}^{8}$. Ainda que os conceitos de polifonia e dialogismo estejam intrinsecamente ligados à área de pesquisa de que me ocupei, como será referido já no ponto 1., não vai ser estudado este filão de intertextualidade - cuja plena fruição depende da competência literária e cultural e da capacidade de construir sentidos de quem lê -, uma vez que não está diretamente relacionado com o objeto de análise deste trabalho.

O resultado da investigação, que se enquadrou nos princípios e orientações do Quadro europeu comum de referência para as línguas (QECRL) ${ }^{9}$, vai ser apresentado em três etapas:

- em 1., será feita uma reflexão sobre a problemática da heterogeneidade enunciativa na língua e no discurso; em seguida, serão definidos conceitos operatórios essenciais, tendo em conta os princípios teóricos que subjazem ao meu estudo - Linguística da enunciação/ textual - e analisadas as formas prototípicas do $\mathrm{RD}$, focando algumas questões prementes por elas suscitadas; uma breve referência às recomendações dos programas oficiais nacionais e aos da Faculdade de Letras da Universidade de Coimbra (FLUC) precede a análise do modo como este conteúdo linguístico é tratado no Dicionário Terminológico (DT) e em algumas das gramáticas de português a que habitualmente recorrem os docentes;

- em 2., serão dilucidados conceitos relativos à representação literária e à problemática da identidade nacional e apresentadas algumas das linhas de força mais fecundas do pensamento português contemporâneo sobre os nossos traços identitários, concedendo também lugar à voz crítica de Mário de Carvalho sobre estas matérias;

- em 3., depois de equacionar brevemente algumas das questões pedagógico-didáticas inelidíveis quando se fala sobre ensino-aprendizagem

\footnotetext{
8 Esta questão será abordada em 2.4 .

9 Cf. infra 3.5.1. O QECRL pode ser também referido apenas como Quadro.
} 
de PLE - nomeadamente no que diz respeito à leitura de textos literários e à sua articulação com o estudo da gramática - será feita a análise de Fantasia..., à luz dos conceitos anteriormente explanados, e apresentada uma proposta de didatização, pensada para alunos estrangeiros do ensino superior, com nível C1 de proficiência em português.

Uma derradeira observação justificativa das epígrafes que escolhi: quando li as primeiras linhas do romance Milagrário pessoal, de José Eduardo Agualusa, ocorreram-me de imediato as questões de que me ocupo: cada palavra carrega, no seu ADN, o peso, a história, a força criativa, as vozes de todas as que a precederam. Mesmo as que, desditosas, parecem definhar sem deixar descendência são parte inegável desse espesso e precioso legado linguístico e cultural que é cada língua, recebida como herança e revivificada pelos seus falantes; Aristóteles e Horácio surgem como tributo aos coronéis Maciel Bernardes e Amílcar Lencastre, personagens chamadas ao título de Fantasia...; Mário de Carvalho não podia, ele próprio, deixar de ser convocado em discurso direto, na abertura do último ponto do trabalho. Todas estas vozes são, no fundo, uma dupla assunção da heterogeneidade discursiva do meu trabalho sobre RD e algumas das fantasias do nosso Portugal contemporâneo declinadas no romance: por um lado, deixando antever as palavras de alguns dos especialistas que têm consagrado o seu labor académico a estudar estas matérias e que se repercutem nestas páginas; por outro, emulando Mário de Carvalho, que recorre habitualmente, nas suas obras, a essa estratégia de citação, como mote anunciador ou iluminador. Faço-o sem pretensiosismo, tão-só como forma de me colocar sob os auspícios de um dos grandes vultos das nossas Letras que completou, em 2011, trinta anos de escrita literária, partilha com os seus leitores uma cultura inaudita, não receia fazer ouvir a sua voz crítica e maneja, como poucos, a língua portuguesa.

O que agora apresento é o resultado de uma pesquisa que mergulhou em complexos problemas linguísticos, literários e pedagógico-didáticos, como aliás acontece com tudo o que diz respeito à Ciência e ao Homem, 
ser pensante, falante e atuante, criador e criativo, irredutível às fronteiras que qualquer investigação acaba por ter de traçar.

No final, serão aduzidas algumas das conclusões possíveis e equacionadas novas questões para as quais não encontrei resposta ou que não couberam no âmbito deste projeto. Por isso, apesar de produto, este texto assume-se desde já, simultânea e principalmente, como possível novo ponto de partida. 


\title{
1. HETEROGENEIDADE ENUNCIATIVA NA LÍNGUA E NODISCURS
}

\author{
Qual seria, na verdade, o papel de quem fala, se o efeito \\ pretendido já fosse evidente sem as palavras?
}

Aristóteles, Poética

\subsection{Questões prévias}

Usamos as línguas naturais para comunicar e para nos comunicarmos, em situações de interação que estão ancoradas num determinado contexto espácio-temporal e relacional, apropriando-nos portanto, de forma única, dos recursos que cada uma delas coloca à nossa disposição e que materializamos em atos de fala. No uso oral ou escrito da língua, mesmo que se trate de um monólogo interior ou explicitado, está sempre subjacente a noção de alteridade, ainda que o "tu» seja um outro «eu»10.

10 Cf. Goffmann: "(...) Le locuteur a tendance à créer "l'effectif complet des deux rôles de la communication - le locuteur et l'auditeur - en l'absence d'un effectif complet d'acteurs pour ses deux rôles" (Goffman apud Vincent). Acrescenta D. Vincent que frequentemente o locutor, querendo transformar um pensamento em ato de fala, utiliza a estrutura «je me suis dit" (Vincent, 2006: 131). Em Português, recorremos muitas vezes à expressão "falar com os seus botões» que, aliás, surge no discurso do narrador, em Fantasia..., relativa à personagem Eleutério: "Pois ainda que vagando sozinho, também faz conversa. Fala com os seus botões. Nem os solitários escapam ao afã elocutório, porque a abotoadura, desde que foi inventada, tem o condão mágico e tradicional de nutrir o paleio» (12). 
Além disso, pode tratar-se de enunciados imaginários, em situações reais ou ficcionadas, relativos a atos de fala (ainda) não concretizados ou não concretizáveis.

Essa atualização de palavras é de facto uma reutilização, onde ecoam, de forma mais ou menos percetível, consciente e intencional, usos prévios que outros falantes delas fizeram. Falar e escrever são, em consequência, atividades que incorporam sempre operações de reprodução de discurso. Ouvir e ler implicam competências de descodificação desses mesmos dispositivos linguísticos.

Neste primeiro ponto, o objeto de análise é aquilo que habitualmente se designa como relato de discurso, que se integra no amplo e complexo domínio dos mecanismos de heterogeneidade enunciativa que a língua nos oferece e que levanta, ele próprio, intrincadas e infindáveis questões. Sendo imperativo delimitar o campo de estudo, e tendo em conta o público-alvo visado em 3. - que é consagrado ao estudo do papel do RD na construção de imagens identitárias em Fantasia... e a uma proposta de didatização para alunos de PLE de nível superior de proficiência -, optei por me restringir às estruturas linguístico-pragmáticas cujas características suscitam menos divergências entre os especialistas, sendo mais consensualmente incorporadas no RD.

Tomo como princípios orientadores da pesquisa a assunção da heterogeneidade enunciativa da língua e do discurso - com os correlatos princípios do dialogismo e da polifonia -, bem como uma matriz de análise ancorada na Linguística da enunciação/textual.

O fim último de uma língua é permitir que os falantes que partilham o mesmo código linguístico comuniquem entre si. Se, numa comunicação interpessoal, um par único («eu»/«tu»), numa situação irrepetível de interação, concretiza, num ato de fala, uma troca bem sucedida de mensagens codificadas, pode perguntar-se o seguinte: por um lado, em que consiste, para além desse processo dual, a heterogeneidade da língua e do discurso e quais as consequências de uma eventual multiplicação de vozes no laço que se estabelece entre os interlocutores; por outro, qual o alcance pragmático das escolhas linguísticas de cada um deles, nesse singular ato de fala. 


\section{Princípios}

Segundo J. Fonseca (1991) ${ }^{11}$, a heterogeneidade da linguagem verbal - que existe tanto na língua como no discurso - deve ser analisada em dois níveis e resulta da sua natureza diassistémica, bem como do facto de estar intrinsecamente orientada para a comunicação intersubjetiva.

Num primeiro patamar, aplicando às línguas o que J. Fonseca designa como "heterogeneidade 1" - isto é, a que decorre da variabilidade e da complexidade de funcionamento dos códigos que integram qualquer sistema semiótico -, consideram-se as diferentes estruturas internas da língua, o seu funcionamento diverso, a interação com variáveis que lhe são externas e a dimensão pragmática que resulta da sua atualização pelos falantes em situações particulares de comunicação, afirmando o linguista que «as condições básicas do uso da língua estão compendiadas na enunciação" (265). Constata-se, assim, que algo exterior à língua - a enunciação - é fulcral na sua organização, sendo um contributo essencial para a sua heterogeneidade, pois inscreve «na língua uma matriz dialogal» $(266,271)$.

Num segundo nível, apelidado de "heterogeneidade 2" - a orientação para a comunicação e para a interação desse mesmo sistema semiótico -, «a língua representa a cristalização de múltiplas vozes que se congregam virtualmente nos signos e nas outras entidades e recursos linguísticos e que estão prontas a ressoar nos discursos", graças à "iterabilidade das entidades linguísticas», constituindo-se, em suma, "complexo depositário e mediador de intersubjectividade" (276)12. Além do mais, "a organização interna da língua tem uma matriz dialógica ou dialogal»(277), de que é paradigma o eixo enunciativo «eu»/«tu» e que introduz a dimensão argumentativa no discurso (278-9). J. Fonseca refere também como exemplos

11 Os princípios que agora vou enunciar seguem o artigo de 1991 de J. Fonseca. Por esse motivo, limitar-me-ei a indicar, entre parênteses, as páginas das citações que faço desse texto.

12 Diz ainda J. Fonseca, na mesma página: "Interessa aqui evocar também, e de novo, a condição diassistemática da língua, agora para destacar que o complexo multilectal que a língua constitui dá testemunho de micromundos, quadros e cenários - culturais, sociais, religiosos, regionais, ideológicos, profissionais, etários e outros - que ficam plasmados e memorizados nas unidades linguísticas». 
desta virtualidade da língua "os mecanismos e instrumentos citacionais», que são "recursos variados, de natureza lexical, semântico-sintáctica, metalinguística e até entoacional, permitindo de modo explícito e segundo modalidades diferenciadas (abarcadas no discurso relatado) projectar num dado discurso outras enunciações» (279). Consequentemente, polifonia e dialogismo são dois vetores intrinsecamente inscritos nas línguas naturais, forjando-se entre a língua e a sua atualização discursiva uma relação de mútua dependência: "A estrutura da língua consagra, na verdade, a preocupação dos virtuais locutores com o Outro, desenhando nós e laços que os interligam e que suportam o consenso e o dissenso, a convergência e a divergência, a harmonia e a conflitualidade, a concórdia e a discórdia” (281).

No que diz respeito à heterogeneidade discursiva, J. Fonseca afirma que é no discurso que "se congregam indissoluvelmente o falar do/sobre o mundo e o falar da/sobre a enunciação", exemplificando o seu caráter múltiplo com a articulação "discurso-metadiscurso", "a construção simultânea de uma multímoda instanciação enunciativa, de uma estruturação local, de organização sequencial e configuracional, de um rumo ou orientação global»(290). Acrescenta que a "heterogeneidade 2» no discurso se encontra primeiro na "identificação de quem fala e a quem...." (290) e que a "beterogeneidade enunciativa", que introduz outras vozes no discurso, se pode desdobrar quer numa "conjugação de vozes que se dão a ouvir ou se fazem ouvir», quer numa "conjunção ou junção de vozes no discurso" - sejam as do locutor e do seu alocutário, sejam a reprodução do discurso de outro (de forma explícita ou implícita, estabelecendo relações de proximidade/distanciamento em relação às palavras relatadas) -, quer na presença de outras vozes (decorrente da já referida polifonia que está inscrita na língua ou do diálogo intertextual que inevitavelmente cada texto estabelece com todos os que foram produzidos/ lidos anteriormente) (291-3). Sustenta ainda J. Fonseca que a capacidade de produzir/interpretar a polifonia e o dialogismo discursivos depende da enciclopédia do emissor/recetor, salientando o desdobramento que muitas vezes ocorre no discurso, de forma mais ou menos evidente, entre "quem diz» e "quem fala» (296). Na sua opinião, é no discurso literário 
que a polifonia e o dialogismo atingem o mais elevado grau de revelação, explorando-se aí uma pluralidade de códigos e oferecendo-se ao leitor "múltiplos efeitos de sentido» (293-4). O linguista realça igualmente o facto de o discurso se instituir simultaneamente como lugar de interlocução e de interação, onde se estabelece um jogo negocial de responsabilidade e influência recíprocas entre os interlocutores. Por isso, deve falar-se de «intersubjectividade no discurso" (302).

Em síntese, a heterogeneidade dos mecanismos que regulam a organização e o funcionamento dos recursos linguísticos é um traço constitutivo da língua e do discurso, o que autoriza e amplia o leque de codificações/ descodificações que se entretece nas relações comunicativas intersubjetivas dos usuários de cada língua natural, onde a enunciação é a pedra de toque.

Assim, o RD é uma das formas de concretização dessa heterogeneidade enunciativa. Aí reportamos/interpretamos as palavras de outro(s) com palavras já usadas por outro(s), tendo sempre em linha de conta a orientação comunicativa para o(s) outro(s). Em suma, o RD é «dizer o outro» (Rosier, 1999: 57, 277), dizendo-se, simultaneamente ${ }^{13}$.

Os conceitos de dialogismo e polifonia merecem mais alguma atenção, uma vez que fecundaram tanto os estudos literários como os linguísticos. O primeiro deve a paternidade a Bakhtine, que defendia «uma concepção interactiva do processo discursivo", pois antecipa sempre uma réplica discursiva que lhe é indissociável (Bakhtine apud Peytard, 1995: 75)14. Esse processo discursivo está intimamente ancorado num contexto, no qual

13 Cf. Volochinov: «Le discours rapporté, c'est le discours dans le discours, l'énonciation dans l'énonciation, mais c'est en même temps un discours SUR le discours, une énonciation SUR l'énonciation" (Volochinov apud Peytard, 1995: 38). Num texto literário, a configuração desse Outro é produto de uma estratégia delineada pelo narrador, que pode comprazer-se na derrogação das regras ficcionais. Isso acontece em Fantasia..., com a personagem Maria das Dores, que diz o seguinte ao narrador: "Você está com má consciência e quer aproveitar-se de mim como passa-culpas. É evidente que sempre me tratou às três pancadas. [...] Agora está a dar-me tempo de antena a ver se se desresponsabiliza” (186).

${ }^{14}$ A este propósito, escreveu Bakhtine: "Le discours de notre vie pratique est plein de mots appartenant à d'autres: il en est dans lesquels nous fondons notre voix, oubliant à qui ils sont, il en est dont nous nous servons pour renforcer nos mots à nous, considérant qu'ils font pour nous autorité, il en est enfin que nous peuplons de nos propres aspirations qui leur sont étrangères ou hostiles» (apud Peytard, 1995: 71). 
se entrecruzam múltiplos discursos de variados sujeitos que participam na interação comunicativa e que veiculam os seus pontos de vista e os seus valores, tendo sempre em linha de conta o recetor (Reis \& Lopes, 2002: 101). Polifónico foi o adjetivo com o qual o linguista russo qualificou um espaço textual caracterizado pela plurivocidade, como é o caso do romance. De facto, a polifonia romanesca, indissociável da noção de pluridiscursividade e de dialogismo, traduz a multiplicidade de pontos de vista e de ideologias que se entretecem no romance, de que é exemplo, ainda que não exclusivo, a relação dialógica entre o narrador e as suas personagens (Reis \& Lopes, 2002: 333-4) ${ }^{15}$. São dois conceitos resultantes da apreensão semântica da subjetividade na linguagem (Perrin, 2006: 5) e indissociáveis da assunção da pluralidade que conforma cada sujeito falante (postulado hoje consensual também na Linguística) ${ }^{16}$. Multiplicaram-se em correntes de estudo que necessariamente propõem abordagens diversas e diversidade de recortes conceptuais e terminológicos ${ }^{17}$.

Em grandes linhas, no domínio linguístico e no que concerne o RD, quer o "dito" quer o "dizer» continuam a ser objeto de interesse: alguns

15 Como já foi referido, em Fantasia..., essa relação é ostensivamente apresentada e estabelece-se mesmo uma espécie de "triangulação" (165) entre personagens e narrador, uma vez que Maria das Dores revela ter conhecimento da concretização e do teor de um diálogo prévio entre o demiurgo ficcional e outra personagem: "Eu sei que chamou a Maria José e que ela se fartou de dizer mal de mim»(186).

16 Os conceitos de heterogeneidade representada - a representação de um discurso outro, produto da representação e da intencionalidade - e de heterogeneidade constitutiva - aquela que, não podendo ser representada pelo sujeito falante, determina o que ele diz - são de J. Authier (Authier-Revuz, 2004: 51-2). Também R. Vion fala de "dialogisme constitutif»: "(...) Cette disposition générale selon laquelle, en l'absence de marques explicites d'autres voix, toute parole résulte d'un ensemble de dialogues avec des opinions et des discours" (Vion, 2006: 105-6).

17 Segundo L. Rosier, apesar das diferenças de enquadramento teórico e dos corpora analisados, a referência comum desses estudos é o termo bakhtiniano "polifonia", que reativou a noção já existente de que os textos "falam»: polifonia do enunciado, da enunciação, da interação, tendo em comum, por exemplo, a reflexão sobre o RD, nomeadamente através do discurso indireto livre (Rosier, 2006: 203-5). A. Rabatel considera persistirem abordagens dicotómicas que acabam por separar, na análise, não apenas marcas formais como também campos de interpretação (2006: 166-7). O n 28 da revista Recherches Linguistiques (2006), onde foram publicados os artigos referidos nesta nota, apresenta um conjunto relevante de estudos sobre dialogismo e polifonia, a nível da língua e do discurso. A análise da pluralidade de perspetivas atuais do RD, nos estudos linguísticos e nos literários, não cabe no âmbito deste trabalho. Fica a referência como testemunho de uma descoberta a explorar em eventuais investigações futuras. 
estudos orientam-se para a análise do enunciado, na senda dos trabalhos de Ducrot sobre a teoria linguística da polifonia, que visa revelar a pluralidade de vozes e de pontos de vista que coexistem no enunciado ${ }^{18}$. Outros redefinem o conceito de dialogismo e privilegiam a análise dos diálogos (por exemplo, Jacques Bres e Aleksandra Nowakowska) ou procuram articular a noção de polifonia com a teoria dos estereótipos ${ }^{19}$. Uma outra via de pesquisa, na senda dos estudos literários, é seguida por A. Rabatel, que estuda a relação entre relato de palavras/pensamentos, acontecimentos e pontos de vista que traduzem o dialogismo e a subjetividade das perceções nos textos narrativos (2004: 81-2) ${ }^{20}$.

Núcleo de convergência neste "oceano do dialogismo e da polifonia" (Rabatel, 2006: 165) - universo desmesurado onde é impossível traçar fronteiras rígidas e onde o pensamento continua a desbravar caminhos e a descobrir profícuas relações interdisciplinares (Rosier, 2006: 65) - é a perspetivação do RD como fenómeno polifónico/dialógico (Anscombre, 2006: 295), a assunção de que a citação é um modo de coexistência da heterogeneidade explícita, marcada, facilmente delimitável e identificável com a heterogeneidade constitutiva de qualquer discurso: «O relato de discurso é uma forma de dizer que o outro não está, no discurso, em todo o lado, mas apenas em certas zonas delimitadas, circunscritas» (Duarte, 2003: 38, que sintetiza o postulado de Authier-Revuz, já referido) ${ }^{21}$.

Estas referências, necessariamente sucintas, a nomes e pistas de investigação atuais estão longe de esgotar o fértil campo de pesquisa dos

18 O. Ducrot ter-se-á inspirado em C. Bally, não em Bakhtine (Dendale \& Coltier, 2006: 273-4). Um exemplo é a ScaPoLine - teoria escandinava da polifonia linguística, de Nølke e Fløttum, que se assume como "théorie énonciative, sémantique, discursive, structuraliste et instructionnelle» (Nølke apud Dendale \& Coltier, 2006 : 279).

19 J.-C. Anscombre defende que cada locutor pertence a várias comunidades linguísticas atrás das quais se esconde quando enuncia princípios gerais que nelas encontram a sua fonte (2006 : 362-5).

20 Num texto de 2004, A. Rabatel afirma preferir "discours représenté» a "discours rapporté»: trata-se de uma expressão que "renvoie à la scénographie énonciative au coeur du DR [...]. Elle laisse mieux entendre les calculs pragmatiques du locuteur/énonciateur du discours citant pour rendre compte des dires et/ou des pensées et/ou des perceptions d'autrui selon l'usage qu'il en a dans le bic et nunc de son énonciation" (2004: 93). "Representação do discurso outro" tinha sido expressão proposta por J. Authier-Revuz (2004: 35 ).

21 Cf. supra nota 16. 
fenómenos de reprodução de palavras no discurso e servem somente de breve enquadramento para o meu trabalho sobre as formas canónicas de RD.

Em síntese, e respondendo já à interpelação aristotélica que abre este ponto 1., assume-se, neste texto, que cada falante, na interação única e ancorada contextualmente que estabelece com o(s) outro(s) no ato enunciativo, seleciona, de entre os instrumentos linguísticos de que dispõe, aqueles que respondem em cada momento às suas necessidades comunicativas e intenções pragmáticas e que devem, depois, ser interpretados pelo(s) interlocutor(es). Esses instrumentos linguísticos são intrinsecamente dialógicos e estão polifonicamente saturados. Assim, a subjetividade e a intersubjetividade inerentes à comunicação verbal manifestam-se discursiva e textualmente, não podendo ser esquecido o papel fulcral dos fatores de natureza extralinguística, seja na construção seja na interpretação desses enunciados. Por isso, para a análise do RD, a orientação metodológica que se impõe é a da Linguística da enunciação/textual, no âmbito da qual passo agora à definição dos conceitos operativos para este trabalho.

\section{Conceitos}

Começo naturalmente pelo de relato de discurso ${ }^{22}$ : trata-se de um processo de citação ${ }^{23}$, que visa reproduzir, oralmente ou por escrito,

22 O DT consagra a terminologia oficial e, por isso, foi uma referência para a minha investigação. O RD está integrado no domínio C. - "Análise do discurso. Retórica. Pragmática e Linguística textual" -, sendo identificado sob a designação de "Reprodução do discurso no discurso" que, neste trabalho, será considerada sinónima de "relato de discurso». O DT está disponível em http://dt.dgidc.min-edu.pt/.

23 Segundo o DT, "citação" é a "Reprodução de um texto ou de um fragmento de texto noutro texto, assinalada com referência ao autor e/ou à obra aos quais pertencem e graficamente demarcada com aspas ou com um tipo de letra diferente». G. Reyes apresenta a etimologia do verbo latino "citare" - que remete precisamente para "chamar, convocar" - e apelida de "citação" a operação que consiste em pôr em contacto, num texto, dois acontecimentos linguísticos, i.e., o processo de representação de um enunciado por outro enunciado, devendo existir marcas formais que o atestem (Reyes, 1984: 58, nota 15). A linguista admite a existência de citação a partir do momento em que o ouvinte reconheça a intenção do falante de evocar um enunciado ou um pensamento alheios, ainda que não esteja presente a reconstrução literal do enunciado daquele que é evocado (Reyes, 1994: 9). Em português, "citação" tanto significa o processo de citar como o seu produto. Neste 
palavras proferidas, pensadas ou antecipadas num contexto enunciativo diferente daquele em que o relato de palavras se atualiza. Este mecanismo de evocação de outra(s) voz(es) - cujas formas prototípicas vão ser analisadas no ponto 1.2.2. - põe sempre em presença duas situações de enunciação e dois sujeitos: ainda que se trate de autocitação, está-se perante um desdobramento enunciativo do sujeito falante ${ }^{24}$. Por isso, em situações de reprodução do discurso no discurso, temos de atender a quem fala, a quem cita, ao ato de fala e ao seu produto, bem como aos contextos em que ocorrem as interações comunicativas.

O Dicionário Terminológico (DT) define "enunciação» como o «acto individual mediante o qual um emissor utiliza e actualiza um sistema linguístico, para produzir enunciados numa determinada situação comunicativa», apresentando "enunciador» como o "sujeito linguístico, com uma determinada identidade psicossocial, que inscreve no discurso a sua subjectividade». Tendo em conta a matriz dialógica dos processos comunicativos, acima explanada, o enunciador inscreve também no seu discurso "O outro, a segunda pessoa do singular ou do plural». No RD, coexistem dois enunciadores, que vão lançar mão de diferentes marcos referenciais, consoante a situação de comunicação que é convocada: a do produtor do discurso que é relatado e a de quem o cita. No primeiro caso, em que está em causa a voz de onde emana o discurso, temos o enunciador primeiro - isto é, aquele que vai ser objeto de citação (Duarte, 2003: 61, nota 2) - ou enunciador citado, locutor primeiro ou locutor-enunciador; no segundo, que diz respeito à voz que materializa o RD, temos o enunciador-relator (ou emissor-relator, emissor-narrador, relator, locutor-relator ou citador). O "alocutário" é aquele a quem se dirige um ato de produção verbal e o «interlocutor» é o recetor de um discurso, podendo assumir, ele próprio, o papel de locutor - quer o

trabalho, tendo em conta que o corpus analisado é uma narrativa ficcional, considera-se existir RD apenas em excertos discursivos onde se reconheça relato de palavras ou de pensamentos de personagens e do narrador.

24 Cf. supra nota 10. 
que produz quer o que relata discurso, uma vez que se trata de papéis constantemente reversíveis (Reis \& Lopes, 2002: 103).

Neste trabalho, por questões de ordem prática, "discurso" é considerado, simultaneamente, como processo enunciativo e como produto desse processo. Também "enunciado" e "texto" podem ser usados como sinónimos, na mesma aceção, tanto na análise linguística como literária.

Vão ser considerados, como verbos introdutores de RD, verbos dicendi - "que significam a realização por um sujeito de um acto de comunicação verbal», segundo o DT - e verbos sentiendi - aqueles que, deixando pressupor a existência de um verbo de elocução, transportam grande valor afetivo e expressivo, contribuindo para o desenho das personagens. Considerei ainda os verbos que fazem parte de expressões cristalizadas da língua - que classifiquei como combinatórias fixas - e os que integram expressões que sinalizam o poder criativo de MC - designadas combinatórias livres.

A classificação dicotómica - dicendi/sentiendi - dos verbos convocados pelo relato de palavras não permite contemplar a ampla escala semântica que o RD pode repercutir e que singulariza cada obra literária, mas a minha escolha fundamenta-se em dois argumentos: por um lado, atendendo a que a análise literária visa perceber como são verbalmente configuradas, no romance, as vozes que sustentam a tese do país verborreico, quis avaliar o peso e o valor expressivo dos verbos de elocução; por outro, considerando que é estrangeiro o público virtual para quem foram pensadas as atividades pedagógicas que vão ser apresentadas no ponto 3. - ainda que se trate de discentes de nível superior de proficiência -, pareceu-me preferível ater-me a uma distinção elementar desses verbos, o que não interditaria, em contexto real de sala de aula, ulteriores e mais aprofundadas classificações dos verbos introdutores de RD e o desenvolvimento de outras pistas de leitura de um romance tão fértil como Fantasia...

Uma vez que vou trabalhar com o RD a nível escrito e o corpus textual que selecionei é um texto narrativo literário, entram em jogo conceitos que apelam a dimensões ontológicas e funcionais distintas das que se consideram nas interações verbais quotidianas, como as díades autor-leitor e narrador-narratário, entidades ficcionais que são, 
elas próprias, testemunhos da relação dialógica constitutiva do uso da linguagem, juntamente com a «bivocalidade dialógica» que o narrador e as suas personagens constituem (Reis \& Lopes, 2002: 330)25. Enquanto o autor/escritor é o sujeito histórico responsável pela criação literária, o narrador é o "autor textual concebido e activado pelo escritor", mais ou menos subjetivamente implicado no enunciado que cria (41). Não só dá voz às suas personagens como assume, com frequência, a função de narrador-locutor: é "o sujeito do discurso" (317) que "configura o universo diegético que modeliza» (259). As palavras das personagens que cria podem revelar maior ou menor autonomia em relação ao seu próprio discurso $(318)^{26}$. O leitor é o recetor empírico do texto escrito pelo autor (217), que este visa na conceção e concretização da sua obra narrativa. Já o narratário é o "destinatário intratextual»(218), i.e., o leitor fictício convocado pela entidade narradora.

Finalmente, e tendo em conta o alcance pedagógico deste trabalho, cumpre explicitar que o QECRL ${ }^{27}$ apresenta uma abordagem "orientada para a acção» e define "competências" como "o conjunto dos conhecimentos,

25 Os conceitos de Narratologia definidos a seguir têm a mesma fonte bibliográfica. Por isso, são apenas indicadas as páginas das citações, entre parênteses.

${ }^{26}$ A já referida diluição das fronteiras entre o criador e as suas criaturas, em Fantasia..., é atestada pela afirmação de poder do narrador, no também já evocado diálogo com Maria das Dores, numa réplica à pergunta da personagem sobre a possibilidade de se ir embora: "Com certeza, por quem é. Até não é impossível que aconteça outra coisa. Imagine que eu a suprimo de todo desta história. [...] E duvido muito de que outro autor se interesse por si» (183). Também a assumida omnisciência do narrador é questionada no romance: Maria José tinha-o corrigido, informando-o de que o filho Nelson ia celebrar apenas o quadragésimo primeiro aniversário (177).

${ }^{27}$ Elaborado pelo Conselho da Europa (CE), em 2001, no âmbito do Projeto "Políticas Linguísticas para uma Europa Multilingue e Multicultural», constitui, juntamente com o Portfolio Europeu de Línguas, um instrumento indispensável para a definição de competências e níveis de proficiência, bem como para a harmonização de práticas no ensino-aprendizagem de línguas vivas, na Europa. Apresenta três níveis de proficiência: elementar (A1 e A2), independente (B1 e B2) e proficiente (C1 e C2). Segundo as recomendações do CE, cada cidadão europeu deve dominar pelo menos duas LE. O Quadro apresenta linhas orientadoras, cuja finalidade última é formar usuários competentes e proficientes nas línguas estrangeiras que estudam, capazes de interagir com os outros e de intervir ativa e positivamente num mundo global, progressivamente plurilingue e pluricultural. Apesar das limitações teóricas, metodológicas e pedagógico-didáticas que têm sido assinaladas por vários especialistas (e.g., C. Puren), que não cumpre debater aqui, é um documento de consulta obrigatória para todos os que ensinam línguas vivas. 
capacidades e características que permitem a realização de acções»28. As competências gerais são «aquelas a que se recorre para realizar actividades de todo o tipo, incluindo as actividades linguísticas", sendo as competências comunicativas, numa língua, "aquelas que permitem a um indivíduo agir utilizando especificamente meios linguísticos»(QECRL, 2001: 29) e que compreendem componentes linguísticas, sociolinguísticas e pragmáticas (QECRL, 2001: 34; Galisson \& Coste, 1983: 134-5).

\section{Interrogações}

Enunciados os princípios teóricos que enformam este trabalho e definidos os principais conceitos que vão ser convocados, justifica-se que sejam equacionados alguns dos problemas suscitados pela assunção da presença de outras vozes no discurso, nomeadamente quando está em causa um texto de ficção, e que surgem logo a partir da definição de RD: as palavras reproduzidas têm todas o mesmo valor ontológico? Há diferenças entre as vozes a que, por exemplo, um jornalista ou um académico dão protagonismo, as que circulam num texto autobiográfico ou as que fazem asserções em textos de natureza judicial? Encontram-se no mesmo plano o RD que surge quando um falante pretende antecipar uma resposta verbal e o que encontramos em textos ficcionais, onde uma entidade narrativa nos dá conta do que dizem e pensam personagens que vivem em mundos imaginários? Pode falar-se de RD quando o que está em causa são pensamentos de personagens que um narrador omnisciente verte em textos literários, muitas vezes sob a forma de monólogo interior ${ }^{29}$ ? Um RD assegura a veracidade e a fidelidade das palavras que reproduz? É exequível - e qual o objetivo que se pretende alcançar com essa estratégia

$28 \mathrm{O}$ conceito de "competência comunicativa" deve-se a Hymes, que a define do seguinte modo: "(...) O conhecimento (prático e não necessariamente explicitado) das regras psicológicas, culturais e sociais que comandam a utilização da fala num enquadramento social" (apud Galisson \& Coste, 1983: 134).

29 O monólogo interior é a representação da corrente de consciência da personagem, que se traduz num discurso formalmente elítico, sincopado, até mesmo caótico (Reis \& Lopes, 2002: 237-8). 
- assegurar a integridade, formal e de conteúdo, das palavras citadas? É possível reproduzir palavras de outrem de forma neutra ou cada discurso é indelevelmente marcado pelo sujeito que o relata? A resposta afirmativa a esta última questão conduz de imediato a outras: no texto, quais são as marcas do sujeito falante e como se delimitam fronteiras? De que funcionalidade(s) se revestem, umas e outras? Quais as consequências pragmáticas da dupla enunciação que o RD exige e corporiza? Qual é a relevância do contexto quando está em jogo a reprodução de palavras? Que recursos linguísticos e paralinguísticos podem ser convocados no relato de palavras, num discurso oral ou escrito? Devemos colocar esta problemática separando inequivocamente textos «reais» de produções ficcionais? E como distinguir, nos textos literários, quem fala de quem vê, i.e., como diferenciar relato de palavras de perspetiva narrativa? Como discernir atribuição de apropriação de discurso?

A todas estas questões de índole ontológica, axiológica, epistemológica e enunciativo-pragmática pode somar-se uma pergunta relevante, tendo em conta os propósitos pedagógico-didáticos deste trabalho: que ilações se devem extrair das respostas às questões apresentadas e que alterações urge desencadear, na sala de aula, quando se estuda com os alunos o RD ${ }^{30}$ ?

\subsection{O relato de discurso}

\subsubsection{Perspetivas de análise}

No domínio dos estudos da língua, a reflexão sobre a alteridade no discurso tem vindo a trilhar um caminho que já é longo, sendo assinaláveis

\footnotetext{
30 Recorro intencionalmente ao vocábulo "alterações», deixando antever a indispensabilidade de modificar as estratégias de abordagem deste conteúdo linguístico sugeridas em grande parte dos materiais pedagógicos que analisei e que, é preciso que se diga, são atualizadas por muitos docentes. Assumo desde já que eu própria tenho reproduzido alguns desses modelos tradicionais que, apercebo-me agora, são geralmente redutores e pedagogicamente pouco profícuos.
} 
as transformações no modo como é encarada a reprodução de palavras nos textos, mercê dos aportes concetuais que diferentes perspetivas teóricas foram introduzindo nesta matéria.

Platão distinguia diegese de representação mimética e de representação mista (2007:392d). A primeira era narração pura, verdadeira, feita pelo poeta e digna de referência encomiástica (2007: 393d-394b). As outras que imitavam na totalidade as falas das personagens ou as combinavam com palavras do próprio poeta - eram objeto de condenação ética porque veículo de deformação moral pela ilusão criada, passível de convidar à emulação ${ }^{31}$.

Pelo contrário, Aristóteles olhava a mimese como traço distintivo dos seres humanos e fundamento de toda a criação artística. Para este filósofo grego, relatar palavras de personagens em ação, no universo da arte da linguagem, era uma das possíveis estratégias de imitação do real, visando o efeito de verosimilhança que estabelece, entre quem cria e quem usufrui da obra criada, um pacto de ilusão que se revela benigno, na conceção aristotélica, desde que respeitadas as regras de conveniência ${ }^{32}$.

A distinção entre oratio recta - estilo direto - e oratio obliqua - estilo indireto - deriva, inicialmente, de diferentes atitudes valorativas sobre a reprodução de palavras. Os postulados dos dois pensadores gregos citados influenciaram a posterior tripartição dos géneros - narrativo, lírico e dramático -, assistindo-se, mais tarde, à assimilação entre mimese e DD, no texto dramático, bem como à translação da perspetiva de análise - da retórica deslizou-se para a gramática. Verifica-se, portanto, que conceção

31 Cf. Platão: "(...) O poeta imitador instaura na alma de cada indivíduo um mau governo, lisonjeando a parte irracional, que não distingue entre o que é maior e o que é menor, [...] a uma enorme distância da verdade» (2007: 605b,c).

32 Cf. Aristóteles: "(...) Imitar é natural nos homens desde a infância e nisto diferem dos outros animais, pois o homem é o que tem mais capacidade de imitar e é pela imitação que adquire os seus primeiros conhecimentos» (2008: 1448b-4). E ainda: "Pelo exposto se torna óbvio que a função do poeta não é contar o que aconteceu mas aquilo que poderia acontecer, o que é possível, de acordo com o princípio da verosimilhança e da necessidade. [...] O poeta é um imitador, como um pintor ou qualquer outro criador de imagens [...]. No que respeita à poesia, mais vale o impossível convincente do que o possível que não convence [...]: realmente, a arte deve superar o modelo" (2008: 1451a; 1460b; 1461b). Em Fantasia..., é o coronel Lencastre que advoga princípios aristotélicos, na discussão sobre literatura que mantém com o vizinho Bernardes (16). 
gramatical do relato de palavras e reflexão sobre narração literária estiveram indissociavelmente ligadas (Reyes, 1984: 77-8).

A tradição escolar acabou por eleger a frase como unidade de estudo e consagrar o princípio transformacional, em que o DD surge como discurso primordial da verdade e o DI é assimilado a algo que foi transposto, modificado e, consequentemente, remetendo para a esfera do falso, do fictício (Reyes, 1984: 14-32). A recuperação integral desse discurso primeiro (aqui, no sentido cronológico do termo, i.e., aquele que foi produzido em primeiro lugar) não só era considerada possível como mesmo sugerida pelos exercícios gramaticais, à semelhança, aliás, do que ainda se verifica atualmente, em muitos materiais pedagógicos. O par DD-DI cristalizou-se no âmbito da gramática da frase, em grande parte devido ao interesse crescente que o DIL suscitou, como forma híbrida e transgressora (Rosier, 1999: 41), a partir dos estudos da narrativa literária no século XIX. Estabeleceu-se, desse modo, um esquema triangular nos processos de reprodução de palavras, em que um dos vértices era olhado como marginal (o DIL), contrapondo-se aos canónicos DD e DI.

Desde a segunda metade do século XX - e a partir dos estudos precursores de Bally, das investigações de Benveniste e da revelação do pensamento seminal do grupo bakhtiniano (graças às traduções das suas obras, escritas em russo), entre outros -, com o desenvolvimento da Teoria da enunciação e da Linguística textual, a abordagem começou a pautar-se, essencialmente, por critérios enunciativo-pragmáticos e semânticos. Ao enquadrar o RD nessas duas correntes linguísticas, assume-se que a análise do modo de reproduzir palavras é indissociável da tríade fundadora da enunciação - enunciador, contexto e destinatário da mensagem -, que marca indelevelmente o enunciado onde, por isso, subjetividade e intersubjetividade são elementos fulcrais. Como consequência, o leque de formas reconhecidas de citação de discurso ampliou-se e complexificou-se.

Se tivermos em conta o binómio diegese-mimese da Antiguidade Clássica - praxis política vs prática poética/retórica (Rosier, 1999: 20-1) e verdade/legitimidade vs verosimilhança -, apercebemo-nos da considerável deslocação do eixo de análise na abordagem da reprodução de palavras: dos âmbitos institucional e retórico-narrativo dos latinos e gregos para 
o nível estilístico-gramatical, em meados do século passado, cuja "visão redutora» (Duarte, 2003: 51) postulava o DD como discurso primordial e verdadeiro, com o correlato DI, dele derivado e subordinado sintaticamente; e, de há mais de três décadas até aos nossos dias, sob a ótica da Enunciação, da Pragmática e da Semântica, para o nível de análise discursiva e textual. A este longo e plurifacetado percurso conceptual correspondeu uma expectável pulverização terminológica.

Outra questão que tem de ser analisada, pela especificidade de problemas que concita, é a do relato de palavras no texto literário. Segundo G. Reyes $^{33}$, a peculiaridade do discurso literário advém do seu estatuto ontológico: ao contrário dos atos discursivos, que são estruturas comunicativas porque estão enraizados no tempo e no espaço, são protagonizados por um locutor e um interlocutor com existência real e têm como referentes entidades do mundo empírico, a literatura, enquanto objeto estético, cria estruturas linguísticas portadoras de sentido fora do seu contexto de produção, uma vez que o universo da ação, as personagens e as suas falas são inventados, i.e., ficção ${ }^{34}$. Sendo imaginário o mundo criado - a literatura é um "simulacro" -, na totalidade ou em parte, é igualmente imaginária a representação discursiva que o escritor dele faz - ou seja, é um simulacro do simulacro (9) ${ }^{35}$. Todavia, pode-se falar de relato de palavras nos textos de ficção: apesar de ser "um simulacro do acto de enunciação, no interior do próprio discurso narrativo" (Reis \& Lopes, 2002: 124), cada ato de fala de uma personagem não é mais do que «um acto pelo qual se mimetiza linguagem com linguagem»(Reyes, 1984: 30). Esses atos de fala remetem para um campo mostrativo que, sendo constituído no texto e pelo texto, é simultaneamente, referencial e textual (F. I. Fonseca, 1994: 229-32), pelo que o estudo dos marcadores deíticos e

33 Para este tópico, segui sobretudo o seu texto Polifonía textual, de 1984, pelo que procederei apenas à indicação das páginas, entre parênteses, sempre que fizer referência a essa obra.

${ }^{34}$ Cf. G. Reyes: «Llamo ficción a la transposición de la actividad lingüística a un contexto imaginario, contexto que hay que reconstruir a partir de su réplica» (1984: 14).

35 Também Bakhtine escreveu: «Le projet de l'auteur sur le héros est projet sur la parole. L'auteur, de par toute la construction de son roman, ne parle pas du héros, mais avec le héros» (apud Peytard, 1995: 62). 
anafóricos exige, de quem lê, a aceitação do jogo ficcional nas operações de transposição enunciativa requeridas pelo estudo do $\mathrm{RD}^{36}$.

Se o material linguístico usado nas estratégias de citação é ontologicamente diverso - as palavras ficcionais não têm o mesmo estatuto comunicativo das palavras reais, como foi dito -, em ambos os casos pode falar-se de polifonia e RD: aceite o jogo ficcional, podem ser idênticos os mecanismos de que o narrador lança mão para a reprodução de palavras das suas personagens, bem como os problemas que eles revelam. Ou então pode haver lugar a subversões mais ou menos criativas, de acordo com o estilo de cada escritor e com a expressividade que pretende alcançar ${ }^{37}$.

Impõe-se então uma pergunta: no momento de escolher o material linguístico para analisar em contexto de aula, quais os argumentos que poderão justificar a escolha de textos ficcionais? Deixando para o ponto 3 . uma sucinta reflexão sobre as virtualidades do estudo de textos literários na aula de LE, pode adiantar-se desde já que, ao contrário do que acontece na por vezes caótica reprodução de palavras das interações quotidianas ou na maioria dos exemplos asseptizados apresentados pelos livros e pelos professores para estudo, os textos literários permitem recuperar o enquadramento das trocas verbais. Tendo em conta a relevância dos vetores contextuais para os mecanismos de reprodução de palavras, não é vantagem despicienda (Reyes, 1984: 193; Duarte, 2003: 25).

Como se deduz do que foi dito até agora, o RD não cabe em definições simples nem em exemplos inquestionáveis. Pelo contrário, exige do professor de Língua Portuguesa (LP)/PLE um esforço de escolha, sistematização e adequação dos conceitos teóricos e das práticas pedagógicas a propor aos seus alunos.

Por isso, pensando na articulação entre abordagem linguística e leitura literária para discentes de PLE, concentrei a minha análise nos modos mais comuns de relato de discurso - DD, DI e DIL -, partindo de exemplos

${ }^{36}$ F. I. Fonseca considera que os anafóricos relevam do que ela classifica como deixis indireta: pressupõem sempre uma referência às coordenadas da instância enunciadora (1994: 293).

37 Algumas das peculiaridades do RD em Mário de Carvalho serão analisadas em 3. O exemplo (6) de 1.2.2. (cf. infra) apresenta uma alteração do DD canónico. 
claros e simples retirados da obra selecionada ${ }^{38}$. Para a ilustração do RD neste trabalho, escolhi preferencialmente as falas de Emanuel Elói, o jovem "trotamundos" (Fantasia..., 14) bem-fadado de nome e de caráter, graças ao qual se tecem as mais inusitadas pontes entre as personagens do romance ${ }^{39}$. Sempre que se revelou impossível encontrar excertos canónicos relativos ao mestre de xadrez/vedor de águas, optei por falas de outras personagens ou do narrador omnisciente. São exemplos de RD apresentados primeiro de forma algo descontextualizada (forneço apenas, em nota, as indicações essenciais para a compreensão mínima dessas falas), convocados para atestar modos de reprodução de palavras presentes no romance, numa etapa do trabalho em que se impõe uma tarefa de descrição e sistematização das marcas linguísticas da heterogeneidade enunciativa. A análise discursiva e textual, fulcral para compreender as virtualidades do RD em Fantasia..., terá lugar em 3., como já foi dito.

Intencionalmente afastados ficam casos-fronteira e situações ambíguas, pois mesmo entre especialistas nesta matéria continuam a existir questões não consensuais, cuja discussão não pode ter lugar numa sala de aula ${ }^{40}$.

\subsubsection{Formas prototípicas de relato de discurso}

No RD, entre o discurso citador e o discurso citado, estabelecem-se relações a vários níveis - morfossintático, enunciativo, semântico-lógico - e o contexto, como já foi referido, torna-se fundamental para a interpretação dos seus efeitos discursivos e pragmáticos (Rosier, 1999: 126-7, 199, 231-2).

38 Assumo o ónus de optar por uma estratégia arriscada, a de ilustrar fenómenos gramaticais com exemplos literários (Reyes, 1984: 193). Todavia, neste trabalho, não seria possível fazê-lo de outro modo.

39 Cf. Anexo 1.

40 No contexto de PLE em que se insere a minha pesquisa e com o objetivo que pretendo alcançar (analisar o papel do RD na construção de imagens identitárias, num romance contemporâneo), creio ser legítimo seguir o que preconiza Rosier para a prática pedagógica: que se parta do canónico para a subversão das regras (1999: 82). No meu trabalho, o objetivo é ater-me ao canónico, embora assinale e comente o valor expressivo das derrogações da norma. 
Aquelas formas de RD a que se costuma chamar canónicas são as que, graças a marcadores formais usuais e geralmente reconhecíveis, permitem mais facilmente definir fronteiras e identificar o duplo movimento de distanciação e de apropriação ativa das palavras citadas (Rosier, 1999: 300): discurso direto, discurso indireto e discurso indireto livre. Devem ser perspetivadas tendo em conta as situações de enunciação, as formas que assumem, as funções de que se revestem, o posicionamento do relator em relação ao que cita, a sua organização discursiva e o grau de verosimilhança pretendido nos textos de ficção (Duarte, 2003: 28-9).

No entanto, a tarefa afigura-se bastante mais complexa do que à primeira vista as formas tradicionais de RD descritas nas gramáticas deixam supor.

\section{Discurso direto (DD)}

O DD é talvez a forma de reproduzir palavras que, à partida, na sua forma prototípica, oferece menos dificuldades aos discentes (quer de LM quer de PLE), pelo tipo de marcação formal que o delimita e fortifica (Reyes, 1984: 204) - dois pontos, parágrafo, travessão, aspas, recurso ao itálico ou a letra maiúscula - e pela aparente facilidade de construção, justapondo falas de personagens:

$$
\begin{aligned}
& \text { (1) - Reponde o jovem: } \\
& \text { - Análises, medições, e coisas assim. Vai-se vivendo. } \\
& \text { - É o que é preciso. }(14-5)^{41}
\end{aligned}
$$

Nesta forma de $\mathrm{RD}$, encontra-se um locutor-relator que introduz o discurso objeto de citação - e que em (1) é o narrador do romance -, pressupondo-se a transcrição ipsis verbis que convida a uma leitura de dicto do DD.

Duas observações se impõem, sobre a atribuição e a fidelidade do DD. Por um lado, a atribuição do discurso pode ser prospetiva (é o caso do exemplo

${ }^{41} \mathrm{O}$ «jovem» é Emanuel, que responde a Eleutério, o seu interlocutor, quando este aceita boleia, na Renault Quatro, depois de ter entornado os frascos de mel. Os exemplos serão apresentados numerados, a partir de agora, com indicação, entre parênteses, das páginas do romance que são citadas. 
transcrito), mediana (2), retrospetiva (3), não existir (4) (Rosier, 1999: 141) - situação em que é o contexto que pode permitir a identificação do(s) locutor(es) ${ }^{42}$ - ou dizer respeito a palavras não verbalizadas (5):

(2) - Pois eu - disse o moço - fico esta noite em Reguengos, falo com a sua rapariga e amanhã, ala, para o Grudemil. (34) 43

(3) - Ah - respondeu Emanuel. (36) $)^{44}$

(4) - (...) Deve ser um deus. O amigo sabe o que é um deus? - Eu só conheço o Deus-pai-todo-poderoso, alto está, alto mora, ninguém o vê, todos o adoram.

- Ná, estes são deuses diferentes. No plural: deuses, está a ver? - Ah, pois, manipansos.

- Sim, mais ou menos isso.

E ficou por ali a conversa. (36) 45

(5) - Pensou o rapaz [Emanuel]: "Por mais que a dita o descreia, senhora, não lhe deis mágoa. Que a humanal verborreia, como o camião de areia, há-de dar consigo n’água.» (37)

Note-se que a preceder o DD é possível surgir uma ampla e significativa gama enunciativa, do discurso narrativizado a um verbo introdutor (Rosier, 1999: 282), cuja função na tessitura narrativa ou na caracterização das personagens pode ser determinante.

Por outro, há que ter em conta aquilo a que I. M. Duarte chama «falácia da fidelidade» do DD, pois a tradicional convicção de que existe

42 Esta ausência da qualificação metadiscursiva do RD favorece o contacto imediato com a interação que é relatada, como se de uma representação teatral se tratasse (Kuyumcuyan, 2006: 148). Como se verá em 3., esta é uma opção numericamente considerável em Fantasia...: o narrador coloca as personagens sozinhas, à boca de cena, o que sobreleva o caráter operático das interações entre elas.

43 Emanuel Elói continua a dialogar com o desafortunado apicultor (cf. supra nota 41).

44 Em Grudemil, antes da simultânea de xadrez, Emanuel responde a Sandra.

45 Cf. supra nota 41. 
uma reprodução literal mais não é do que uma idealização (2003: 61-3) ${ }^{46}$. Também G. Reyes considera que, sendo sempre obrigatória a recontextualização do texto citado, a imagem verbal que é dada nunca pode ser completa nem fiel (1984: 59). O mesmo se verifica nas trocas verbais do quotidiano, devido a limitações da memória ou a finalidades pragmáticas do locutor (1984: 144). Excetuam-se, naturalmente, situações específicas, como as académicas, judiciais ou jornalísticas, onde é determinante a reprodução literal, que deve obedecer às regras específicas de cada um desses contextos ${ }^{47}$.

No DD - em textos ficcionais ou em outras interações verbais, orais ou escritas - existem dois discursos, independentes a nível sintático e correspondentes a duas situações de enunciação distintas, a que cita e a que é citada, ainda que se trate de autocitação. Nos cinco exemplos já aduzidos, estão presentes a enunciação do narrador e a das personagens a quem ele escolhe dar voz ${ }^{48}$.

46 R. Vion postula o seguinte: "La stratégie de discours direct vise à créer un effet de réel, à donner l'impression que les paroles rapportées sont authentiques et que le locuteur s'efface devant elles. Il convient, bien entendu, de ne pas confondre cet effet de réel avec une reproduction fidèle de la réalité». Na verdade, no relato de palavras, trata-se de uma "mise en scène énonciative", indissociável do conceito de polifonia, que revela diferentes graus de adesão ou de distanciamento do locutor (Vion, 2006: 109-11, 119).

${ }^{47}$ As regras de estilo da escrita jornalística podem originar textos imprevistos, como o que foi comentado por Rui Bebiano, a propósito de um, publicado no Diário de Notícias, em Dezembro de 2009: dois militares perdidos na serra do Alvão interpelaram um pastor e foram salvos por ele. Bebiano transcreve, da notícia sobre o sucedido, o DD desse pastor e comenta, em seguida, o texto do jornalista: "Cerca da meia-noite fui acordado por dois elementos da GNR, solicitando a minha ajuda para encontrar dois militares que estariam perdidos junto da queda das Fisgas", contou Sérgio Alves. "Munido de uma pequena lanterna, acompanhado de dois bombeiros, fui de imediato para a ravina seguinte à queda de água e cerca das 02.30 consegui ir até meio do declive. Tinha a certeza de que só poderiam estar ali. Fiz sinais, chamei e ouvi uma voz." Ou os pastores já não são o que eram, ou o convívio com o português-padrão usado pelos jornalistas deste país está nos píncaros lá pelas margens do Olo, ou então estamos perante um fenómeno do Entroncamento deslocado do seu lugar onde" (Bebiano, 2009). Como se constata neste exemplo risível, a presunção de fidelidade relatora nos textos dos mass media informativos pode não se confirmar.

${ }^{48}$ A este respeito, e reportando-se a uma gramática de língua francesa, R. Vion assinala a incoerência da afirmação de que, no DD, existe um apagamento do narrador por detrás da personagem cujo enunciado reporta. As abordagens enunciativas têm em conta a polifonia do DD, na senda do preconizado por Bakhtine, e postulam a subjetividade de todo o RD (2006: 106-7). A. Kuyumcuyan fala de logro acerca do desaparecimento do narrador nos diálogos romanescos (2006: 148). É uma estratégia calculada, inerente ao jogo ficcional, que resulta de escolhas do narrador e solicita a adesão cúmplice do leitor. 
Na literatura contemporânea, a ortodoxia tende a ser recriada, como acontece em Fantasia..., quando, por exemplo, o narrador dialoga com a personagem Maria das Dores:

(6) - Podemos falar agora?

- Agora cá!

Brincamos?

- Não às mesmas coisas.

Eu estava a sugerir que conversássemos um bocadinho.

- Sirva-se. É um momento tão bom como outro qualquer... (182)

Neste excerto da conversa metalética que entabula com a mulher de Bernardes, o narrador opta por não fazer preceder as suas próprias falas do habitual travessão. Para além da marcação da diferença de estatuto entre a criatura e o seu criador, a intenção poderá ser facilitar a distinção entre as duas vozes: a que não se subjuga às exigências formais do RD (narrador) e a da personagem que fala (Maria das Dores).

A presumível simplicidade do DD revela-se afinal ilusória, devido à heterogeneidade das vozes em presença. Com efeito, para além da descrição dos traços tipográficos e das marcas morfossintáticas específicas, esta forma de citar discurso exige que se proceda a uma caracterização enunciativo-pragmática. Afirma I. M. Duarte que o DD - que geralmente surge como complemento direto do verbo que introduz o discurso relatado - cf. supra exemplo (5) - respeita o sistema de referências do locutor citado, o ego-bic-nunc da sua enunciação: pessoa gramatical, expressões adverbiais deíticas, tempos verbais que remetem para o «agora-hoje-ontem-amanhã» (F. I. Fonseca, 1994: 294), como o Presente, o Pretérito perfeito simples e o Futuro do Modo Indicativo. Todavia, sendo a heterogeneidade uma característica intrínseca do discurso (como foi dito em 1.1.), a reprodução de palavras em DD decorre de escolhas feitas pelo relator, da sua intenção comunicativa e, por isso, não é enunciativamente neutra, ao contrário do que a gramática tradicional ensina (Duarte, 1999: 114; 2003: 61-2). A improbabilidade de se conseguir reconstituir o contexto em que o ato de enunciação ocorreu - ou de prever aquele 
em que ocorrerá ou poderia ocorrer - pode conduzir a que a intenção comunicativa do locutor citado seja desvirtuada ${ }^{49}$. Também o verbo introdutor do RD e/ou o discurso atributivo (aquele que introduz o DD) ou ainda o que se lhe segue estão muitas vezes eivados da subjetividade do locutor-citador e podem assumir um papel relevante quer na descrição de ambientes quer na caracterização das personagens, como se constata no exemplo seguinte:

(7) - Emanuel aplica-se a prestar consolação ao disfórico apicultor: - O meu amigo deixe lá, prò ano há mais abelhas, mais mel, pode ser até que a cotação do mel suba.» $(34)^{50}$

O uso da língua em DD é predominantemente expressivo e nele abundam, frequentemente, frases exclamativas, interjeições, partículas modais, registos menos vigiados, traços que visam sugerir pronúncias típicas, construções clivadas, expressões oralizantes, topicalizações, entre outras possibilidades (Duarte, 2003: 73-5). Esses traços de verosimilhança, num enunciado que assume um caráter "histriónico" (Reyes, 1993: 15) e que se pretende o mais próximo possível do que foi, será ou teria sido dito pelo locutor primeiro, colocam entraves a uma eventual transformação DD-DI (Duarte, 2003: 51):

(8) - Meu Deus, os cães! (60) 51

Exemplos como este não costumam surgir nos materiais pedagógicos, pela evidente perturbação das regras canónicas que configuram. Em

49 Óscar Lopes considera que para cada DD há tantos DI quantas as possibilidades combinatórias das coordenadas de espaço e de tempo do relator (1971: 258), ou seja, os habituais exercícios derivacionais das gramáticas tradicionais enfermam de falta de rigor e coartam a reflexão linguística.

50 Cf. supra nota 41. O narrador realça a boa índole de Emanuel Elói, numa manifestação de empatia que se vai multiplicar no romance.

${ }^{51}$ Emanuel tenta escapar da casa de Januário, depois de um serão e de uma partida de xadrez que correram mal. 
contexto de aula, enunciados que derrogam as normas podem ser um frutuoso ponto de partida para uma reflexão metalinguística.

$\mathrm{O}$ alcance pragmático do DD varia num amplo espectro, que pode ir da validação de uma perspetiva (o argumento de autoridade, que sugere a proximidade do citador com as palavras relatadas) ao distanciamento crítico de quem reproduz o discurso do outro e o deixa expor-se para melhor o submeter a uma reprovação impiedosa:

(9) - Olha, mas é o nosso professor. Sandra, trá-lo cá!

Mas porque é que eu estou a mentir? Que impulso entranhado me faz desviar da verdade dos factos e optar por uma elevação de linguagem algo aristotélica, embelezada, mas totalmente incompatível com a opaca e endurecida realidade que há? O que o homem disse não foi "trá-lo", de acordo com a gramática, mas "trázio", de acordo com os seus hábitos. (54-5) ${ }^{52}$

Este excerto revela o paradoxo entre os bastidores da ficção (a «artesania da escrita" de que fala o narrador na página 216) e a pretensa "verdade dos factos": a corruptela "trázio" é um traço caracterizador do enunciador primeiro (Januário), confere verosimilhança ao discurso e revela ainda que a entidade narradora se demarca criticamente dele.

\section{Discurso indireto (DI)}

Apresentado comummente como contraponto do DD, o relato de palavras em DI convoca em geral as ideias de complexidade - devido à estrutura sintática de subordinação que exige - e de alteração - transposição de palavras de um locutor primeiro para as de um relator.

52 Em Grudemil, Januário encontra Emanuel, na rua, depois da simultânea de xadrez, e decide levá-lo para sua casa, para jantar. O exemplo (8) é relativo à situação perigosa em que Emanuel se encontrou depois desse serão. 
Para além da dependência estrutural - este modo de relatar palavras apresenta-se como oração subordinada integrante ou completiva com função de complemento direto da oração principal, onde se inicia o RD com um verbo de comunicação -, o DI exige, geralmente, uma leitura de re, i.e., dando primazia ao conteúdo, pois cabe ao locutor-relator parafrasear o discurso tido pelo locutor primeiro, o que resulta muitas vezes num relato de palavras contaminado pela perspetiva do relator: este pode transmitir a força ilocutória do enunciado sem manter intocado o seu conteúdo proposicional (Duarte, 2003: 86)53.

Não é isso que se verifica no seguinte exemplo:

(10) - Perguntei-lhe onde estávamos e ele respondeu-me que na escuna do capitão António de Faria. (118) ${ }^{54}$

Atente-se, agora, no modo como o narrador transmite a seguinte fala de Januário:

(11) - Chamava-se Januário e assim declarou com um rijo aperto de mão, por cima do banco (...). (55) 55

Uma citação ortodoxa das palavras da personagem resultaria no seguinte enunciado: «Ele declarou que se chamava Januário».

A alteração formal levada a cabo pelo narrador (supressão da conjunção subordinativa e alteração da ordem dos elementos da frase), juntamente com a escolha do verbo dicendi ("declarou»), tem um alcance expressivo superior ao de uma reprodução de dicto, uma vez que permite pôr em evidência o caráter enfatuado da personagem. Esta subversão das regras do DI prototípico levou-me a classificar o exemplo (11) como modo híbrido ${ }^{56}$.

53 Volochinov afirma: «L'analyse est l'âme du discours indirect [...]. Qui intègre la parole d'autrui à son propre discours se fait adaptateur-traducteur» (apud Peytard, 1995: 40).

${ }^{54}$ Emanuel relata a Angelina, a empregada da estação de serviço, algumas das suas aventuras imaginárias com ressonâncias de O Livro Grande de Tebas, Navio e Mariana (MC, $1^{\mathrm{a}}$ ed. 1982).

$55 \mathrm{Em}$ Grudemil, Januário apresenta-se a Emanuel, que tinha sido inesperadamente levado por Sandra para dentro do Saab.

56 Cf. infra ponto 3. 
Como irei referir em 3., o DI ocupa um lugar pouco significativo em Fantasia... (3,4\% das ocorrências de RD), não se registando situações em que inequivocamente se constate a referida contaminação do DI pela subjetividade do relator.

A tradução que se opera ao relatar palavras em DI pode ser mais ou menos fiel ao discurso primeiro - o locutor-citador pode optar por assinalar, no seu discurso, a presença do locutor-citado, nomeadamente através daquilo a que J. Authier-Revuz chama "îlots textuels»57 e que traduzem uma escolha de quem reproduz o discurso -, mas o seu valor mimético, se comparado com o do DD, é consideravelmente reduzido. Curiosamente, segundo Reyes, no que diz respeito à exigência de fidelidade no RD, somos mais exigentes com o valor de verdade do "estilo indirecto" (para G. Reyes, o equivalente ao DI), pois o "estilo directo» (o DD) beneficia da complacência de quem sabe que a memória é falível (1993: 26).

Em termos enunciativo-pragmáticos, o DI pode considerar-se mais simples, uma vez que existe apenas um sistema enunciativo: o do relator (Duarte, 2003: 78). Por isso, se no DD se recorre a deíticos, no DI podem ser convocados os anafóricos. Se estiver em causa o «então - nesse dia - na véspera - no dia seguinte - nessas circunstâncias» (F. I. Fonseca, 1994: 294, 312), o tempo verbal principal será o Imperfeito, a que se associam o Condicional58 e o Mais-que-perfeito (simples ou composto), havendo que respeitar a consecutio temporum na oração subordinada (Fonseca, 1994: 78).

Em (12), dois exemplos ilustrativos de interrogativas indiretas, no discurso do narrador:

57 I. M. Duarte apresenta o conceito de J. Authier: ilhotas textuais são as palavras do discurso primeiro citadas entre aspas (2003: 93). Este processo é recorrente no discurso do narrador de Fantasia... - e.g., nas páginas 53, "chamada "estacionamento em segunda fila" ", 104, "chamadas "grandes superfícies" ou 55, enunciado reproduzido no exemplo (9), com o objetivo de caracterizar uma personagem representativa de um determinado espaço social e cultural ("mas "trázio!"»).

58 Também chamado Futuro do Pretérito, sendo frequentemente substituído pelo Pretérito imperfeito do Indicativo (Cunha \& Cintra, 1984: 451, 634). 
(12) - Ao café, e aos brandies, a conversa acabou por recair sobre pesquisa de águas. Maria José inquiriu se era um dom, o coronel Bernardes perguntou se ele por fotografias também lá ia [...]. (219) 59

A homogeneidade enunciativa do DI pode revelar maior ou menor grau de expressividade. Na transcrição anterior, onde se encontra RD traduzido em duas interrogativas indiretas, podemos constatar que a segunda - a reprodução da pergunta de Maciel Bernardes, «também lá ia" - é mais sugestiva, pois evoca traços de oralidade da personagem. É mais "impressionista», para usar a designação de I. M. Duarte, que retoma uma distinção bakhtiniana e postula a existência de dois tipos de DI: um mais "pictórico" ou "impressionista", onde são retomados traços expressivos do enunciador citado, e outro que se restringe à reprodução do conteúdo proposicional. A citação de palavras relativa a Maria José ( inquiriu se era um dom») corresponde a um DI que se atém ao conteúdo referencial do discurso da personagem. Esta diferença revela os matizes de que o DI se pode revestir e atesta a possibilidade de esta forma de $\mathrm{RD}$, que introduz alguma sobriedade no discurso e permite acelerar o tempo narrativo, apresentar também algum grau de mimetismo e de expressividade (Duarte, 2003: 91-7, 105, 194).

Por vezes, torna-se difícil circunscrever o DI - pode confundir-se com discurso narrativizado -, bem como discernir quem cita de quem é citado (Reyes, 1984: 44). Neste trabalho, e à semelhança do que propôs G. Reyes (1984: 32), só considero relato indireto de palavras quando, de facto, ocorrer reprodução de discurso. Atente-se ainda que, se pode haver DD relativo a reprodução de pensamentos, situação semelhante raramente ocorre em DI (Duarte, 2003: 118). Finalmente, cumpre reiterar que o DI não deve ser considerado como produto derivado do $\mathrm{DD}$, como se afirma em grande parte das gramáticas normativas, cujos exercícios transformacionais DI-DD supõem a possibilidade de recuperação da fala

59 Emanuel janta com os dois casais, no monte de Bernardes, depois de detetar um lençol freático na propriedade de Maria José e de Lencastre. 
original, mesmo sem apresentarem as coordenadas enunciativas do discurso reproduzido.

\section{Discurso indireto livre (DIL)}

Se, apesar das gradações já referidas, DD e DI são passíveis de caracterização mais ou menos consensual, o DIL suscita as mais díspares análises, que resultam da dificuldade não só de o circunscrever como de o definir. Alguns linguistas defendem uma noção estrita de DIL, outros postulam um conceito abrangente. Alguns vêem-no como fenómeno exclusivo de textos literários, outros entendem que o DIL pode ocorrer em interações orais quotidianas.

Em suma, entre os estudiosos do RD subsistem divergências quanto aos critérios de identificação e de delimitação do DIL, porque o único aspeto que de facto não levanta celeuma é a problematização que essa forma de reproduzir palavras suscita ${ }^{60}$.

Neste trabalho, adoto a perspetiva de I. M. Duarte, que considera o DIL como uma forma de RD prevalente em textos literários e operativo se analisado em termos discursivos e textuais. Defende a linguista que o DIL é uma forma inequívoca de relato de palavras ou pensamentos, em determinadas ocorrências discursivas, sendo difícil atestar a sua presença fora de textos narrativos literários ou em enunciados orais. No DIL, coexistem duas vozes, a do narrador e a da personagem, que podem estar unidas por laços de cumplicidade ou em pólos diametralmente opostos, ao serviço de uma intenção crítica (Duarte, 1999: 118; 2003: 125-6). Quando este tipo de RD se encontra plasmado num excerto textual, verifica-se o apagamento da subordinação sintática (daí a designação de «livre»), abrindo caminho à presença de marcas linguísticas incompatíveis, por exemplo, com o DI. A propósito do exemplo (8), salientei a impossibilidade de reproduzir a fala de Emanuel em DI, preservando todas as palavras proferidas. Se se tratasse de um DIL, esse constrangimento desapareceria e

60 Para esta questão, veja-se, por exemplo, I. M. Duarte (2003: 123-79). 
o discurso poderia incorporar todos os traços expressivos do enunciado que surge, no romance, em $\mathrm{DD}^{61}$.

Em termos enunciativos, no DIL, atesta-se a presença simultânea de dois sistemas de referência, "fazendo de conta que é possível essa fusão de mundos e de vozes" (F.I. Fonseca, 1994: 315): o "antes» do locutor-relator - no que diz respeito à pessoa gramatical e aos tempos verbais, sendo o Pretérito imperfeito do Indicativo um dos seus traços distintivos - e o "aqui» e "agora" do locutor-enunciador - presente nos deíticos temporais/espaciais e nas marcas formais de expressividade, muitas vezes de oralidade, abundantes neste tipo de RD. Por isso, o DIL congrega subjetividade da personagem e efeito mimético, resultantes em grande medida de afinidades com o discurso oral (Duarte, 2003: 145-7, 241)62.

Esta forma de citar pode traduzir palavras verbalizadas, estando eventualmente presentes no enunciado verbos ou expressões que reenviam para/sugerem RD. É o que acontece no exemplo seguinte, em que o DIL de Emanuel surge na sequência de uma pergunta de Bernardes («inquiriu o coronel»):

(13) - Se trazia uma varinha de freixo, inquiriu o coronel [...]. Não, senhor, ele usava antes uma tira de metal. Era mais eficaz. E exibiu uma folha de aço flexível e barulhento (...). (66)63

O DIL pode ainda revelar pensamentos, materializando aquilo que G. Reyes designa como "fantasia epistemológica» (1984: 75), autorizada pela ficção narrativa graças à produtividade de que se reveste, pois permite "dissecar [...] o interior da personagem» (Duarte, 2003: 168):

61 Por exemplo: «Sem saber como, por escadas e portas desconhecidas, acabou por se encontrar em frente do portão. Ouviu-se um rosnar de tipo escavadora caterpillar e Emanuel estremeceu. Meu Deus, os cães, que seria dele agora?».

62 I. M. Duarte crê que o fenómeno oral que mais se aproxima do DIL é o discurso infantil do "faz de conta" (2003: 243).

63 Emanuel Elói apresenta-se no monte de Bernardes com o objetivo de procurar água para a futura piscina do coronel. Nos exemplos que vão ser aduzidos, o DIL surge sempre sublinhado. 
(14) - Emanuel vai configurando na cabeça o que poderá sair em cada tabuleiro. O bigodaças sisudo fez deslizar o peão de torre para quatro. Mau! Perda de tempo. Um que não devia estar ali. Na terceira passagem, quando já havia duas aceitações do gambito, olhou pela janela, que era dum primeiro andar. (212) ${ }^{64}$

No DIL, os tempos/modos verbais utilizados são anafóricos: os Pretéritos mais-que-perfeito e imperfeito e o Condicional (Duarte, 2003: 150)65.

A sobreposição de vozes e a diluição ou elisão de marcas sintáticas contribuem para tornar o DIL refratário a regras inequívocas. Não raras vezes são ambíguas as vozes que protagonizam a enunciação e, em consequência, o estudo do DIL - forma de RD particularmente polifónica - entronca na problemática da focalização narrativa. Cabe ao leitor atento e competente um papel incontornável na sua identificação e na apreciação das funcionalidades estéticas e críticas de que se reveste nos textos em que se plasma (Duarte, 2003:160, 163-6, 235).

Antes de concluir a apresentação das três formas prototípicas de RD, creio ser pertinente reiterar que, sobretudo em textos literários contemporâneos, podem encontrar-se enunciados que escapam ao cânone, subvertendo regras definidas, nomeadamente gramaticais e tipográficas, como aliás já foi ilustrado com os exemplos (6) e (11). Veja-se o seguinte excerto de uma fala de Tiago, o jovem com aspirações a um lugar no panteão da $7^{\mathrm{a}}$ arte nacional:

(15) - Então é assim... - e foi relatando.

Sem aceitar responsabilidades, eu tentarei sintetizar:

Um serial killer esfaqueia uma vítima, na Mouraria. O inspector que o persegue há anos intriga-se com um objecto que encontra perto. É uma fotografia emoldurada dos pais do inspector. Há várias

\footnotetext{
${ }^{64}$ Emanuel está a disputar uma simultânea de xadrez, em Beja.

65 Sobre o Condicional, cf. supra nota 58.
} 
perseguições de carro e múltiplos flash-backs a mostrar a vida do polícia em jovem. [...] (163) ${ }^{66}$

$\mathrm{O}$ «eu» da frase introdutora do segundo segmento de citação de palavras ("eu tentarei sintetizar») é o do narrador que, tendo identificado o enunciador primeiro (Tiago, no DD de "- Então é assim...»), se assume como mera caixa de ressonância do discurso da personagem. O distanciamento irónico da afirmação "eu tentarei sintetizar» sublinha a verborreia da personagem - o que vai ser oferecido ao leitor é uma ladainha de lugares-comuns - e instaura a infração às regras de reprodução de palavras: não é um relato de palavras em $\mathrm{DD}$, mas também não se trata de DI, nem sequer de uma opção discursiva que se possa enquadrar no que qualifiquei como modo híbrido ${ }^{67}$. É um exemplo formalmente marginal, se tomarmos como referência o cânone do $\mathrm{RD}$, mas que, desnudando implacavelmente a presunção, a verbosidade e a vacuidade de Tiago, atesta a vitalidade criativa de MC e confirma o texto literário como espaço de plena realização de todas as possibilidades da língua ${ }^{68}$. Pela sua relevância na construção de imagens nacionais em Fantasia..., vou retomar este exemplo em 3.

Em contexto pedagógico, tendo sempre presente a especificidade do público-alvo, pode ser muito fecundo iniciar e orientar os alunos na leitura de textos com exemplos menos ortodoxos de discursos polifónicos, contribuindo dessa forma para a ampliação das suas competências comunicativas, literárias e culturais.

Como síntese, pode afirmar-se que, para além das formas prototípicas que à partida colocam menos dificuldades em determinar «quem disse o quê» (Rosier, 1999: 65), a reprodução de palavras surge com

66 Tiago conta a Neusa e a Nelson as suas ideias para filmes de ação, numa fala que se estende por quase trinta linhas do romance (163-4).

67 Cf. infra ponto 3.

68 Cf. infra ponto 2 . A propósito do conceito de "cronovelema", afirmou o escritor: «E tudo isto tem que ver com o decorrer dos tempos. Hoje já não podemos escrever como se fazia no séc. XX. Há outras experiências e realidades» (L. Duarte, 2010: 11). O RD revela ser um dos mecanismos discursivos contaminados por essa subversão das regras. 
frequência em enunciados marcados de tal forma pelo hibridismo que suscitam dúvidas quanto à circunscrição e atribuição de relato. Muitos teóricos, conscientes da impossibilidade de classificar inequivocamente todas as ocorrências discursivas de $\mathrm{RD}$, abandonaram os modelos rígidos de classificação e postulam um continuum de formas que traduzem diferentes intenções comunicativas e expressivas e provocam variados efeitos de sentido quando lidas na sua dimensão textual (Rosier, 1999: 125; Duarte, 2033: 174).

\subsubsection{Outras formas de citar palavras}

Das formas que integram alguns modelos escalares de heterogeneidade enunciativa propostos por vários especialistas do $\mathrm{RD}$, destaco apenas duas que, em situação de aula de PLE, podem ser produtivas, pelas virtualidades expressivas de que se revestem: a ironia e o Discurso direto livre (DDL) ${ }^{69}$.

A ironia - referida a propósito do exemplo (15) - pode ser uma das formas de polifonia que os alunos mais facilmente reconheçam e interpretem nos textos. Todavia, pode igualmente verificar-se que, atendendo ao seu inexorável enraizamento histórico e cultural, se torne obscura, sobretudo para alunos estrangeiros. Evoco-a aqui pela sua funcionalidade no romance de $\mathrm{MC}$, tendo como referência a análise de G. Reyes: o enunciado irónico funciona em dois níveis de significação - o literal, de que o locutor se distancia, e o subentendido, que é dele próprio. Esta duplicidade exige do interlocutor/leitor capacidade de compreender o alcance crítico do enunciado irónico (1984: 154-69)70.

69 Há uma outra questão que releva da problemática da heterodiscursividade - os provérbios - que pode tornar-se muito operativa na aula de LE, pelo substrato linguístico, pragmático e cultural que transporta. Em Fantasia..., Maria das Dores recorre a essas máximas anónimas que condensam um saber coletivo e essa caraterística da personagem vai ser comentada no ponto 3. MC, aliás, considera que "Os provérbios fazem parte da versão culta da língua” (Santos, 2009: 268).

${ }^{70} \mathrm{~A}$ ironia pode também ser perspetivada, por exemplo, como derrogação da máxima de qualidade, numa estratégia deliberada de desrespeito pelo princípio da cooperação que, 
Se o interlocutor conseguir descodificar a intenção crítica, estabelece-se entre os dois um jogo de cumplicidades revelador do sucesso pragmático visado pelo locutor.

Demarcando-se à partida do discurso que vai resumir, o narrador do exemplo (15), pela escolha do verbo e emprego do Futuro ("tentarei»), expõe a impossibilidade de sintetizar a avalanche discursiva redundante e oca a que pretende poupar o leitor ${ }^{71}$.

Veja-se ainda o seguinte exemplo:

(15) - Caso este Emanuel fosse um jovem interessado em si próprio encontraria maneira de ler nas semanas próximas os periódicos contendo as entrevistas. Ficaria a saber coisas dignas de registo. Com a rapariga, que aliás desperdiçara toda uma noite abraçada ao interessado, em actividade alheia ao tabuleiro, sem lhe ocorrer, sequer, confirmar as respostas, aprenderia o seguinte: que a dificuldade do xadrez era um mito clássico, que tinha sido inventado por um sujeito chamado Filho Deodoro que geralmente punha umas vendas nos olhos dos seus adversários e assim ganhava muitos jogos, e que um desafio que ficara na memória do entrevistado era a simultânea entre Kasparov e Napoleão. $(209-10)^{72}$

Ao optar pela reprodução literal de um excerto do texto que teria sido redigido pela jovem jornalista de Beja e publicado no seu jornal, o narrador evidencia uma sequência de dislates risíveis, reveladores da falta de profissionalismo e de cultura de Tânia, lacunas aliás extensíveis à sua classe profissional, pois nem os colegas nem o editor se aperceberam da incoerência das afirmações produzidas

\footnotetext{
segundo Grice, regula as trocas comunicacionais entre os falantes (Reyes, 1995: 38-40). O recetor da mensagem percebe "que se diz algo e se implicita o contrário do que se diz" (Lima, 2007: 63).

${ }^{71}$ Sobre os valores do futuro, veja-se Cunha \& Cintra (1984: 457-8).

72 Emanuel foi entrevistado, em Beja, por Tânia, uma jornalista estagiária. O narrador resume o texto jornalístico que resultou dessa entrevista.
} 
pela estagiária. Obviamente, Emanuel não aprenderia nada com esta leitura, caso a tivesse feito. Por isso, o registo do narrador é irónico, porquanto lhe subjaz uma opinião diferente da que é declarada, já que ele se demarca criticamente daquilo que transcreve. O desconchavo das afirmações de Tânia é por demais evidente, pelo que me parece que mesmo alunos não-nativos perceberiam sem dificuldade a polifonia do exemplo.

G. Reyes considera que a ironia de um texto literário é um reflexo do sistema de valores do autor, sendo por isso fundamental que o narratário, no processo de construção de sentidos, seja capaz de recuperar as informações implícitas (1994: 56). Em (16), é a imagem de um grupo profissional - nos dias que correm, detentor de enorme visibilidade e, consequentemente, de grande responsabilidade social - que é posta em causa pelo escritor. Creio ser legítima esta ilação sobre a opinião que MC tem sobre um certo jornalismo medíocre, sobretudo se pensarmos numa personagem do romance Era bom que trocássemos umas ideias sobre o assunto: a jornalista Eduarda Galvão ${ }^{73}$. Os dois últimos exemplos de Fantasia... manifestam o distanciamento do narrador em relação à mundividência das suas personagens, pelo que a reprodução de discurso marcada pela ironia crítica cumpre um papel essencial na configuração identitária plasmada no romance.

Relativamente ao DDL, que se libertou dos constrangimentos sintáticos e tipográficos próprios do DD (Duarte, 2003: 202), também se coloca, com frequência, o problema da delimitação de vozes, o que pode aumentar o grau de ambiguidade enunciativa no discurso. Como se trata de uma modalidade de RD com considerável expressão na literatura contemporânea ${ }^{74}$, poderá ser fecundo estudá-la com alunos estrangeiros, a partir de um certo grau de proficiência em LP.

73 Cf. Era bom que trocássemos umas ideias sobre o assunto (1 ${ }^{\mathrm{a}}$ ed., 1995). MC explicou, numa entrevista, que Eduarda representa um "certo jornalismo juvenil despachado que por aí existe" (Cotrim, 1996: 46). No referido romance, leiam-se, por exemplo, as páginas 85-8 (ed. de 1996).

74 Como se verá em 1.3., o DDL já está recenseado em gramáticas pedagógicas. 
O DDL está presente em Fantasia..., como se pode constatar no exemplo seguinte:

(16) - Emanuel optou alegremente por uma aula muito básica e preliminar. Quem é que sabe como é que o peão se mexe? Grande alarido, bom convívio e divertimento. (51) 75

A frase sublinhada reproduz uma pergunta do jovem mestre de xadrez sem a mediação formal do narrador, tratando-se, por isso, de um exemplo de DDL.

Para além da materialização do RD sob formas não atestadas nas gramáticas normativas, encontramos em romances atuais um peculiar encadeamento entre diferentes modalidades de reprodução de palavras, ampliando a ressonância polifónica dos textos literários ${ }^{76}$ e desafiando uma capacidade a que G. Reyes chama "poliaudición» (1984:40), i.e., a capacidade de resposta ativa do recetor para pôr em marcha processos de descodificação que cruzem, também eles, múltiplas vozes, construindo sentidos a partir do diálogo entre a sua enciclopédia própria e as escolhas linguísticas e enunciativo-pragmáticas que modelam os discursos.

Em contexto pedagógico, cabe aos professores a tarefa de auxiliar os alunos a dotarem-se das "normas estéticas específicas» (Reyes, 1984: 26-7, 40) e das competências de leitura essenciais para que a perceção da heterogeneidade discursiva dos textos literários, plurifacetada e em contínua mutação criativa - nomeadamente no que à reprodução do discurso no discurso diz respeito - seja oportunidade de aprofundamento linguístico, de fruição estética e de maturação reflexiva, que lhes permita um olhar crítico sobre si próprios, sobre o mundo e sobre o(s) outro(s) ${ }^{77}$.

\footnotetext{
75 Emanuel está em Grudemil, dinamizando uma simultânea de xadrez. O DDL está sublinhado.

76 Um excerto ilustrativo em Fantasia... é uma fala de Sandra (49-50), que vai ser referida em 3 .

77 Esta questão vai ser retomada no ponto 2 .
} 


\subsection{O relato de discurso nos programas de ensino de Português e nas gramáticas}

A consulta dos programas de LP/Português surgiu como etapa inevitável, antes da análise das gramáticas. Registando-se ainda uma relativa escassez de orientações pedagógicas especificamente direcionadas para o ensino-aprendizagem de português para não-nativos, esses documentos funcionam como uma bússola para muitos professores, que procedem em seguida às adaptações consideradas necessárias, consoante os discentes e o seu nível de proficiência (com frequência, trata-se do universo de docência de PLNM). Devido à minha formação inicial e experiência profissional, concentrei-me nos $2^{\circ}$ e $3^{\circ}$ Ciclos do EB e no Ensino Secundário (ES).

A análise dos programas do $\mathrm{EB}^{78}$ permitiu-me concluir que houve um nítido progresso de 1991 para 2009: anteriormente adstritos à área do "Conhecimento Explícito da Língua», os mecanismos de reprodução de discurso no discurso surgem enquadrados, nos Novos Programas de Português do Ensino Básico (NPPEB), em diversos domínios de estudo. Os docentes devem operacionalizar as indicações programáticas de modo a orientar os discentes numa abordagem do RD progressiva e integradora, linguística e pragmaticamente correta e, ao mesmo tempo, pedagogicamente proveitosa.

No ES ${ }^{79}$, há uma década já que as orientações do ME preconizam o estudo do RD no âmbito da Pragmática e da Linguística textual. Adivinhando o percurso que a maioria dos alunos terá feito no EB, abordando o RD da forma tradicional já referida, será de suma importância que, nos três anos finais do ensino não superior, a reflexão e a prática pedagógicas permitam colmatar eventuais lacunas na apropriação dos mecanismos de reprodução de palavras.

Visando a didatização que vou apresentar em 3., consultei também os programas do Curso Anual de Português para Estrangeiros (CAPE), que funcionou de Outubro de 2010 a Junho de 2011, na FLUC. Selecionei

\footnotetext{
78 Cf. Anexo 2.

79 Cf. Anexo 2.
} 
esse curso - em detrimento dos intensivos e dos de Língua Portuguesa ERASMUS - porque os objetivos que defino para o meu público-alvo virtual não são compatíveis com uma aprendizagem da língua que pretende responder a necessidades práticas e urgentes da comunicação quotidiana, como acontece nesse tipo de formação intensiva.

No que diz respeito às unidades curriculares que integram esse CAPE, tomei como referência as de Língua Portuguesa I e II (correspondentes ao primeiro e ao segundo semestres letivos, respetivamente) de cada um dos níveis (elementar, intermédio e superior). A pesquisa ${ }^{80}$ permitiu-me concluir que, no nível superior, o RD não está explícito nos programas, uma vez que foi objeto de estudo nos níveis precedentes. Todavia, os conteúdos programáticos previstos para o nível C1 contribuem para que os alunos desenvolvam a capacidade de fazer uma análise discursiva dos mecanismos de reprodução de discurso no discurso e de os enquadrar numa leitura mais ampla e crítica dos textos. A título de exemplo, no nível superior, estuda-se a articulação de subclasses de pronomes com a deixis pessoal, valores aspetuais e modais dos verbos, marcação da subjetividade na enunciação, o implícito, expressões idiomáticas, ironia, adequação do registo ao contexto de comunicação e a normas sociais, matérias linguísticas muito operativas, por exemplo, para a análise da heterodiscursividade em Fantasia...

Como ainda não abundam, no nosso mercado editorial, materiais pedagógicos específicos para o ensino-aprendizagem de PLE, o professor precisa muitas vezes de recorrer aos que foram concebidos para o estudo de português como LM. Por isso, na resenha que apresento sobre a forma como o RD é tratado em cinco gramáticas de português, apenas uma tem como público-alvo específico docentes e estudantes de PLMN (Gramática de Português Língua Não Materna, L. Arruda, 2008). Optei por duas gramáticas de referência - as de Celso Cunha e Lindley Cintra (Nova Gramática do Português Contemporâneo, 1984) e Evanildo Bechara (Moderna Gramática Portuguesa, 2006) - e por duas direcionadas sobretudo para o público do ensino não superior: uma da Porto Editora, que 
anuncia, no subtítulo, tratar-se de uma "Gramática do Discurso e Gramática da Língua» (Itinerário Gramatical, de O. Figueiredo e E. Figueiredo, 2009) e outra da Lisboa Editora (Gramática Prática de Português, de M. O. Azeredo, I. Pinto e C. Lopes, 2009), porque foi atualizada em função do DT e é a única que apresenta um caderno de exercícios, das mesmas autoras (Exercícios - Gramática Prática de Português, 2010).

No DT, o relato de palavras insere-se no domínio $C^{81}$ (âmbito da comunicação e interação discursivas) e contempla cinco formas de reprodução do discurso no discurso - a citação (reprodução de texto com referência obrigatória à fonte), DD, DDL, DI e DIL -, definidas segundo critérios enunciativo-pragmáticos.

Em L. Arruda (2008), a abordagem do RD é feita no âmbito do estudo do verbo. Em duas páginas apenas, DD e DI são apresentados contrastivamente, sendo proposta, como único percurso de análise, a transformação do primeiro no segundo. Referindo-se ao DD, a autora indica que o verbo introduz palavras "tal qual foram produzidas" (177), ressalvando-se a possibilidade de o DI dizer respeito não a falas mas a pensamentos de personagens. São fornecidas aos alunos duas grelhas, que confrontam essas duas formas de citar discurso: a primeira sintetiza as diferenças entre DD e DI, a nível da pontuação, uso de tempos/modos verbais, pronomes e advérbios de lugar e de tempo; a segunda apresenta dois exemplos em DD e os correlatos em DI, assinalando as dissemelhanças entre ambos. Esta gramática não indica o nível de proficiência linguística do seu público-alvo, mas, no prefácio, a autora explica tratar-se de um conjunto de materiais resultante da sua prática letiva junto de estudantes universitários de PLE, realçando o intuito de propor um documento pedagógico sintético, dado existirem no mercado gramáticas de excelência para o estudo aprofundado da sintaxe. Compreende-se a preocupação de Arruda em não oferecer a alunos estrangeiros um instrumento de trabalho com um elevado grau de complexidade: alunos dotados de competências linguísticas de nível superior podem e devem consultar gramáticas mais completas. Todavia, se creio poder justificar-se, por exemplo, a não in-

81 Cf. supra nota 22. 
clusão do DIL nesta obra, parece-me demasiado elementar a abordagem das duas formas canónicas de RD que estão representadas: restrição da análise ao nível da frase; escassez e descontextualização dos exemplos; apresentação da perspetiva transformacional, neste caso de sentido único (DD para DI).

Em C. Cunha e L. Cintra (1984), o RD merece um tratamento mais extenso e refletido, num capítulo intitulado "Discurso directo, discurso indirecto e discurso indirecto livre». Este capítulo 20 vem na sequência do capítulo que aborda as figuras de sintaxe e precede o que diz respeito à pontuação. Na senda da filiação normativa desta gramática, as «Estruturas de reprodução de enunciações» remetem essencialmente para o universo da ficção literária: essas estruturas são definidas como "moldes linguísticos» usados pelo narrador (note-se que, nesta gramática, são assimilados autor e narrador) para dar "a conhecer os pensamentos e as palavras de personagens reais ou fictícios" (629). Todos os exemplos aduzidos provêm de obras literárias de autores consagrados. Na Nova Gramática do Português Contemporâneo, a ênfase é colocada nas questões semântico-sintáticas (na página 633, refere-se a necessidade de se acomodar alguns elementos de uma frase que se transforma de DD em DI "ao novo molde sintáctico») e o relato de palavras remete para o campo da estilística (aliás, "estilo" surge como sinónimo de "discurso"), realçando os "efeitos artísticos»e as «intenções expressivas» que oferece (633). Os exemplos não ultrapassam o nível da frase e pertencem a narrativas literárias. É igualmente assinalada a transformação de DD em DI, embora se observe haver «um esvaecimento das realidades concretas de tempo e lugar a que as pessoas e coisas referidas estariam vinculadas" (633), sendo enumeradas as alterações dos pronomes pessoais e demonstrativos, dos tempos/modos verbais e dos advérbios de lugar. Não existe referência aos advérbios de tempo. O DIL é definido como produto da conciliação de DD com DI, uma "Construção híbrida" (636), oriunda da literatura, que muitas vezes se articula com o DD e o DI e onde o contexto é fulcral para a plena apreensão das falas ou pensamentos das personagens.

Apesar de se constatar, à luz do que foi enunciado anteriormente sobre o RD, alguma inadequação na abordagem da reprodução de palavras 
(sobretudo na afirmação da objetividade dos mecanismos de citação), Cunha e Cintra aduzem elementos de análise que revelam sensibilidade à complexidade da questão: quer para o DD, quer para o DI, quer para o DIL, os linguistas enunciam traços expressivos característicos destes mecanismos de "reprodução textual» de discurso (630) que completam a descrição formal que fazem de cada um, realçando as suas virtualidades estéticas - a teatralidade e função "actualizadora" do DD, por exemplo (632) -, bem como o seu papel como elemento caracterizador das personagens. É ainda sustentada (pelos autores) a possibilidade de utilização deste recurso linguístico na comunicação quotidiana, para além da do universo literário, mas não são apresentados exemplos.

E. Bechara (2006) inclui DD, DI e DIL no estudo da «Estrutura do enunciado ou período. A oração e a frase», mais concretamente no ponto em que são analisados os grupos oracionais e as orações complexas. As referências que faz são sucintas e superficiais, mas afirma que a ideia de fidelidade absoluta do relato de palavras é um pressuposto que pode não ser cumprido. O papel dos verbos sentiendi na construção do retrato psicológico da personagem é também referido. Em nota de pé de página, o linguista considera que um nível mais profundo de análise releva não da gramática mas da linguística do texto (482). Nessa mesma nota, aduz uma referência bibliográfica para os interessados em aprofundar a questão. Esta gramática, por isso, não fornece elementos adicionais ao docente que pretenda uma abordagem do RD mais direcionada para a prática pedagógica.

O Itinerário Gramatical (2009), de O. Figueiredo e E. Figueiredo, insere a "Reprodução do discurso no discurso" no Capítulo 3 ("Escrita") da Parte I ("Gramática do Discurso»). Após a definição de "polifonia», "locutor», "enunciador» e "destinatário» do discurso, convocando o conceito de "dialogismo", procede-se à explicação dos mecanismos que permitem integrar "as falas dos "outros" no discurso do "eu" (63). São apresentadas cinco formas de relato de discurso: DD, DDL, DI, DIL e discurso evocado. Relativamente ao DD, mantém-se a asserção da fidelidade da reprodução de palavras, são assinaladas as marcas tipográficas que o introduzem e apresentadas as três posições possíveis do 
verbo introdutor (apelidado de "verbo relator de discurso") na frase. O DDL é ilustrado com três exemplos (um de texto de imprensa e dois de escritores portugueses contemporâneos - José Saramago e António Lobo Antunes), procedendo-se, em seguida, à explicitação deste modo de RD: é assinalada a ausência de símbolos tipográficos e realçada a presença de deíticos e, eventualmente, de segmentos em itálico. O DI tem direito a um breve parágrafo, onde se destaca a subordinação a um verbo introdutor e a concordância dos tempos verbais, sendo referida a fidelidade não às palavras mas ao "conteúdo de pensamento" (66). Não são apresentados exemplos, restringindo-se à apresentação das suas "regras» juntamente com as do DIL, pois, afirma-se, têm características idênticas. São apresentadas as "transformações" (66) que ocorrem, nomeadamente as alterações dos tempos verbais e a transposição dos deíticos para os anafóricos, sendo salientada a grande diferença entre os dois: no DIL, a conjunção subordinativa está ausente e em geral o mesmo acontece com o verbo relator. O exemplo aduzido pertence a Eça de Queirós ( $O$ crime do Padre Amaro). Finalmente, explica-se que o discurso evocado diz respeito a estratégias de distanciamento do que é dito - «segundo», «diz-se», ... (66).

Como aspetos positivos, assinalam-se o enquadramento da problemática do RD no âmbito da polifonia e do dialogismo (embora este seja escassamente definido, o que se pode compreender tendo em conta o público-alvo) e a ampliação do leque de formas de citação referidas (nomeadamente o DDL). Não obstante, creio existir um desequilíbrio na abordagem das várias formas de relatar palavras (o DI recebe uma atenção mínima), nada é dito sobre a relevância do contexto enunciativo e existem algumas incorreções graves: numa secção consagrada aos verbos introdutores de $\mathrm{RD}$, surgem as frases «Ela tagarelou constantemente que não queria comer» (63), como exemplo de DI, e "Ele refutou não sabia de nada", ilustrando o DIL (63). No primeiro exemplo, há claramente uma incompatibilidade entre o verbo escolhido para relatar palavras e a oração subordinada que ele introduz. No segundo, e tendo em conta que o DIL é um fenómeno discursivo, creio que a frase apresentada é manifestamente insuficiente para atestar a sua presença. Além do mais, 
afirma-se que o DIL é utilizado com muita frequência na língua oral e na língua literária (66). Apesar de se tratar de uma questão controversa, como já foi dito, não me parece que se possa asseverar a existência de um elevado número de ocorrências de DIL, na linguagem oral, sem apresentar dados empíricos. Para atestar a validade dessa afirmação, esperar-se-ia que fosse apresentado pelo menos um exemplo dessa forma de RD. Parece-me também existir uma confusão entre «enunciador»e "locutor»: define-se "locutor» como "a pessoa responsável pelo discurso", que se distingue das "vozes de outros enunciadores" (62); em seguida, surge a noção de "enunciador", no discurso evocado, como aquele que "recorre a meios simples e discretos para indicar que não é responsável pelo enunciado que ele cita” (66).

A Gramática Prática de Português (2009), de M. O. Azeredo, I. Pinto e C. Lopes, trata a "Reprodução do discurso no discurso" no Capítulo VIII ("Análise do discurso. Pragmática e Linguística textual»). Os conteúdos abordados são o DD, o DI, o DIL, o DDL, os verbos introdutores do RD, a citação e a polifonia. Os exemplos são elaborados a partir de um cartoon, o que permite reconstituir o contexto da enunciação. É apresentado um quadro de sistematização das alterações DD-DI, mas é previamente explicado o papel das coordenadas enunciativas, surgindo mesmo um exemplo de DI com o verbo introdutor do RD no Presente do Modo Indicativo. Mantém-se a noção de reprodução textual de palavras no DD. Em relação aos verbos, são aduzidos vários exemplos literários, nomeadamente da autoria de Eça de Queirós, chamando a atenção para a sua carga expressiva e para a função que assumem na caracterização das personagens. O DIL é apresentado como mecanismo quer de enunciados orais quer escritos mas, também aqui, é ilustrado apenas com excertos literários. O DDL é sucintamente caracterizado, registando-se um exemplo de Memorial do Convento, de José Saramago. Finalmente, são definidas "citação" e "polifonia", esta última exemplificada de forma restrita com dois diálogos que o narrador de Viagens na minha terra, de Almeida Garrett, entabula com o seu leitor. O livro que acompanha esta gramática (Exercícios - Gramática Prática de Português), elaborado pelas mesmas autoras, propõe exercícios mais completos e profícuos 
do que os que habitualmente se encontram em materiais pedagógicos. Surge novamente um cartoon para desencadear a reflexão sobre o RD (134), seguido de exercícios que permitem aos alunos manipular os mecanismos de reprodução de palavras, com tarefas de transformação que propõem a variação das coordenadas da enunciação, exigem não apenas a observação das mudanças formais como dos seus efeitos expressivos, solicitam a delimitação de fronteiras (no caso do DDL), apresentam uma frase ambígua em DI para que o discente proponha várias possibilidades em DD (137) e sugerem atividades com um leque variado de verbos introdutores do discurso (141), estratégia fundamental para alargar a competência lexical dos alunos (Duarte, 2001).

Em síntese, as conclusões que decorrem da sucinta análise de três obras com vocação pedagógica corroboram em grande medida as que já foram referidas em estudos prévios (Duarte, 1999: 113; 2003: 417) ${ }^{82}$. Em dois deles, a abordagem do RD fica reduzida à inventariação das mudanças morfossintáticas ocorridas em processos transformacionais (DD-DI e vice-versa), à seleção de exemplos inequívocos e descontextualizados de reprodução de palavras, limitados muitas vezes à frase ou quase exclusivamente literários, sem incidência sobre a relevância das coordenadas enunciativas, o que não encoraja uma apreensão refletida das estruturas de RD e dos seus possíveis efeitos estéticos e pragmáticos. Nesta amostra do mercado editorial, a Gramática Prática de Português destaca-se e o caderno de exercícios que a acompanha pode ser um ponto de partida inspirador para os docentes que pretendem levar a cabo, nas suas aulas, um estudo rigoroso, sistemático e enriquecedor da reprodução de palavras no discurso.

O percurso de reflexão teórica e de aplicação de conceitos relativos ao RD a Fantasia..., que agora concluo, permite asseverar que os mecanismos de reprodução de palavras - manifestação da heterogeneidade da língua, pois convocam duas situações enunciativas -, não podem ser abordados sem que se tenha em conta as marcas da enunciação e o contexto

82 Fora desta apreciação ficam naturalmente as gramáticas de C. Cunha/ L. Cintra e de E. Bechara. 
em que se concretizam, porquanto desempenham um papel decisivo na construção e descodificação, linguística e pragmática, desses mecanismos.

A natureza das palavras relatadas depende do tipo de enunciado em causa. Se, em textos que remetem para o universo da realidade, a fidedignidade das palavras relatadas pode ser fulcral - e.g., instâncias judiciais, académicas ou jornalísticas -, em situações do quotidiano o mais importante pode ser a transmissão do conteúdo proposicional do discurso proferido. Em qualquer dos casos, é fundamental recusar uma perspetiva derivacional, uma vez que não existe um discurso primordial de onde provenham outras formas de citação de palavras.

Tratando-se de universos literários, o pacto ficcional que se firma entre o narrador e o narratário está "assente na duplicidade de um fazer acreditar e de um querer acreditar» (Simões, 2006: 80). Nesse contexto específico, a "representação da voz da personagem", do registo mais mimético conseguido com o DD à "confluência de vozes" do DIL, passando pelo DI (Reis \& Lopes, 2002: 321) - fazendo referência apenas à tríade aqui analisada com mais profundidade -, integra uma retórica específica do texto literário e traduz a subjetividade quer do narrador quer das personagens (Reis \& Lopes, 2002: 209). Por isso, o RD, enquanto sinal de plurivocidade, pode ser um instrumento fundamental na construção de sentidos, relevando o alcance pragmático de quem orquestra as vozes de um texto (cf. supra citação da Poética).

Relativamente à delimitação da citação e à atribuição do discurso, atestou-se ser muitas vezes difícil - senão impossível, em algumas circunstâncias - traçar fronteiras inequívocas entre o dito e o dizer de cada um dos enunciadores em presença.

Apesar destes obstáculos, é muito importante que, em contexto pedagógico, sejam proporcionados aos alunos momentos consistentes de reflexão metalinguística, com componente de aplicação prática variada, que os habilitem a dispor adequadamente de um recurso linguístico de grande valia, quer como usuários da língua que falam/leem/escutam/ escrevem, em situações do quotidiano, quer como leitores precavidos, para que compreendam e apreciem, em cada situação textual concreta, as funcionalidades do RD. Desta forma, poderão constatar como nos textos 
as palavras ganham expressividade e espessura e deixar-se seduzir pelo desafio da polifonia literária, retirando da leitura o prazer que ela pode proporcionar.

Ao terminar esta primeira etapa do meu percurso de investigação, foi apenas possível responder a algumas das questões formuladas inicialmente. Cumpre agora tentar perceber que instrumentos conceptuais podem sustentar a textualização de imagens identitárias nacionais.

A edição de 2003 de Fantasia... orienta de imediato a aproximação do leitor ao romance, pois a Caminho optou por um elemento paratextual a capa - semanticamente saturado: a piscina é, por metonímia, Portugal. Mas como pode um país caber numa obra ficcional? 
(Página deixada propositadamente em branco) 


\section{LITERATURA E CONSTRUÇÃO DE IMAGENS I D E N T I T Á R I A S}

As tuas ficções, se queres causar prazer, devem ficar próximas da realidade e não se pode apresentar tudo aquilo em que a fábula deseja que se creia.

Horácio, Arte Poética

\subsection{Literatura e representação}

No ponto 1., ficou explanado o jogo polifónico que é ativado em cada interação verbal, oral ou escrita, e foi explicitada a falácia da pretensão de fidelidade no processo de reprodução de discurso no discurso, quer se trate de atos comunicativos reais quer diga respeito a universos fictos. Neste domínio, foi evocada a teia de cumplicidades que se tece entre o narrador e o(s) seu(s) narratário(s) - o pacto ficcional - e que autoriza a leitura de um texto literário como configuração de mundos possíveis, não de mundos reais. Esta afirmação exige alguma reflexão adicional sobre o modo como neste trabalho se perspetiva o fenómeno literário e sobre o papel que cumpre a cada uma das entidades envolvidas nesta equação ficcional ${ }^{83}$.

A noção da natureza convencional da representação discursiva (Leerssen, 1991: 166), i.e., de que um texto não reflete o mundo "tal

83 Cf. supra 1.1. 
qual ele é» mas uma perceção particular, única, histórica, sobre esse mundo, é corroborada pela seguinte asserção de J.-M. Grassin, que surge na sequência de uma reflexão sobre a natureza polissémica do vocábulo imagem: "Encore moins que l'image plastique, l'image poétique n'est ni la réalité, ni un calque de la réalité; mais l'évocation d'une réalité perçue, une réalité reconstituée mentalement dans ses traits saillants grâce à l'art de l'écrivain" (Escarpit, s.d.). Concebendo-se a literatura como um sistema modelizante secundário (à semelhança dos outros sistemas culturais), na senda da escola soviética de Tartu, ela tem de ser encarada não como "uma imagem do mundo, mas sim uma visão do mundo" (Silva, 1983: 94), em busca não da verdade mas da verosimilhança - na linha aristotélica $^{84}$ - e instituindo uma coerência e uma coesão próprias nos textos que a materializam. A apropriação e original configuração que cada criador faz dos múltiplos códigos de que se entretece o sistema modelizante literário e que se plasmam nos igualmente pluricodificados corpora - eis a "art de l'écrivain".

Esses códigos que estruturam os textos literários convocam leituras multímodas (Silva, 1983: 100). A este propósito, afirma ainda J.-M. Grassin, também no Dictionnaire International des Termes Littéraires: "L'image littéraire est ainsi un fait de style, effet de texte [...]; si le lecteur-spectateur ne se situe pas dans la bonne position, dans la bonne disposition, il ne voit rien. L'image apparaît à partir des points de vue du texte, celui où l'auteur place son lecteur». Esses pontos de vista não são perspetivas preenchidas que restringem a leitura a um único sentido. Eco fala dos "espaços em branco" que, por duas ordens de razões, todo o autor semeia nas suas produções ficcionais: por um lado, porque cada texto "vive da mais-valia de sentido que o destinatário lhe introduz" e, por outro, porque "pretende deixar ao leitor a iniciativa interpretativa, ainda que habitualmente deseje ser interpretado com uma margem suficiente de univocidade. Um texto quer que alguém o ajude a funcionar. [...] É emitido para que alguém o actualize», i.e., "postula a cooperação do leitor como condição própria da sua actualização",

${ }^{84}$ Cf. supra 1.2.1., nomeadamente a nota 32. 
porquanto "gerar um texto significa actuar segundo uma estratégia que inclui as previsões dos movimentos do outro" (Eco, 1993: 55-7) ${ }^{85}$. Esta condição inerente a todo o texto de ficção não é isenta de riscos, como lembra o teórico italiano, pois existe a possibilidade de se verificar um desfasamento de competências entre quem escreve um texto e quem o pretende descodificar, caso se trate de um leitor "enciclopedicamente carente» (Eco, 1993: 56-8).

A referida modelização secundária operada pelo polissistema literário acarreta uma transmutação do estatuto da língua natural que lhe serve de veículo: torna-se "língua literária» (Silva, 1983: 146). A perspetiva da literatura como desvio da língua-padrão é recusada por E. Coseriu ${ }^{86}$, reiterado por Aguiar e Silva, que considera o texto literário o local de revelação "de todas as virtualidades da língua»(1983: 172). O sistema literário, acrescenta, comporta um "banco de dados do sistema", ou seja, é um dos elos da "tradição literária" de cada língua (1983: 258). É essa memória que permite, por exemplo, a polifonia intertextual e pode ser a sua ausência, ou o escasso conhecimento que dela possui, a causa do desencontro de competências, a que Eco alude, entre um leitor desmemoriado e um narrador que se deixa tocar profunda

85 U. Eco faz uma analogia entre o processo de escrita/leitura e estratégias militares ou de um qualquer jogo, como o xadrez, afirmando depois que «a noção de interpretação supõe sempre uma dialéctica entre a estratégia do autor e a resposta do Leitor-Modelo" (1993: 57-62), ou seja, verifica-se uma interseção de estratégias discursivas. Em Fantasia ..., o leitor que se configura no horizonte de expectativa do narrador é evocado, por exemplo, na p. 61: "Mas eu não sou um escritor manipulador, especioso em ganchos, clif-hangings e outros artifícios para prender a atenção do narratário. [...] Eu sou franco, não há arcas encouradas, digo logo tudo». O leitor vai aperceber-se da ironia desta declaração de intenções que não é cumprida pelo narrador. Para além do mais, a metáfora do xadrez é uma linha de sentido que se pode extrair dos espaços em branco do romance: é personificada por Emanuel Elói, peça determinante que põe em movimento todos os peões que constroem o tabuleiro nacional. O jogo de xadrez, aliás, surge noutras obras de MC, como E se tivesse a bondade de me dizer porquê?, escrito com Clara Pinto Correia (1996: 54-5).

${ }^{86}$ Afirma o linguista romeno que o discurso literário «actualiza todas las posibilidades del lenguaje mientras que otros discursos, al contrario, parcializan y desactualizan posibilidades del lenguaje. El discurso literário debería ser, en realidad, por el hecho de que puede presentar todo tipo de procedimientos, la pauta para considerar otros tipos de discursos en cuanto reducciones del tipo más rico, o del discurso que actualiza virtualmente todas las posibilidades del lenguaje" (1990: 3). 
e profusamente por notas literárias que ecoaram antes dele, como acontece com $\mathrm{MC}^{87}$.

Esta forma de olhar a literatura como lugar textual de plenitude funcional e criativa que autoriza a fuga à ortodoxia do $\mathrm{RD}$, já referida em 1.2.2., não colide com a assunção do particular estatuto ontológico do discurso literário, também já analisado em 1.2.1., a propósito do relato de palavras de carateres ficcionais: sendo de natureza diversa as palavras proferidas em contextos comunicativos reais das que reproduzem falas de personagens criadas por um narrador, ativam mecanismos linguísticos semelhantes. As implicações pedagógicas deste ponto de vista sobre o fenómeno literário serão apresentadas em 3.

Em síntese, os sentidos urdem-se através de um movimento dialético entre o que um texto propõe/oculta e a perceção que cada leitor configura a partir dele, sendo este seu ponto de vista necessariamente circunstancial, ancorado num tempo e num espaço a que a sua mundividência não está imune. Para além disso, a memória literária é alimentada igualmente pelas interpretações plurais que uma mesma obra suscita(ou). Existe, por isso, uma rede semântica polifónica a sustentar toda a análise textual.

A leitura de Fantasia... que vou propor é, por isso, mais uma malha que integra a espessa teia de sentidos que têm sido construídos a partir do romance. Atendendo a que o meu ponto de vista diz respeito à configuração ficcional de imagens identitárias do Portugal do século XXI, é imperioso tentar responder a duas novas questões: como se define identidade nacional e como podem ser textualizados traços identitários de um povo, num romance que procura refletir uma imagem verosímil do país.

87 Cf. infra 2.4. Como se verá em 3., Fantasia... revela com eloquência a força criativa do discurso literário que o distancia das interações verbais quotidianas, nomeadamente no que ao RD diz respeito, e é espaço de explosão polifónica em constante diálogo com a memória literária. 


\subsection{Identidade nacional}

Quando aplicada a nações, a abordagem psicologizante é desagradável. Engraçados, estes estereótipos mais não são do que caricaturas apropriadas para charlas: os belgas seriam maçadores, os franceses chauvinistas, os alemães eficientes, os escoceses forretas, os espanhóis barulhentos, os irlandeses bêbados, os ingleses fleumáticos, os suecos frios, os gregos hirsutos e, segundo a versão pós-modernista, os portugueses teriam medo de existir. Ora, como isto não se me aplica, tenho de concluir estar errada a nacionalidade que o passaporte me atribui. (Mónica, 2009: 88-9)

Estas palavras de F. Mónica, que enumeram traços identitários nacionais estereotipados, lugares-comuns sobre diversos povos, a doxa relativa a vários dos nossos vizinhos europeus ${ }^{88}$, põem em evidência, em registo irónico, a cautela que deve presidir a qualquer pretensão de definir uma nação, um povo, uma identidade nacional. E, no entanto, em Fantasia..., podemos ler:

Entre a poeirada de adversidades que ensombram e inquinam a já de si pequenina qualidade de vida dos portugueses existe uma prática ilegal e, portanto, livremente exercida, chamada "estacionamento em segunda fila”. (53)

Neste país, pelos anos fora, tinha havido tanta guerra e tanta desgraça, que podia acontecer que uma panelita cheia de moedas... (142)

A segunda entrevista foi dada a um alentejano tagarela que, para não desmerecer do nacional portuguesismo falava, falava, falava [...]. (209)

Estas três transcrições do romance - que salientam a escassa "qualidade de vida" nacional, a incivilidade impune, um longo passado comum

88 A característica que nos é atribuída - o "medo de existir» - é um piscar de olho ao título de uma obra de 2005 de J. Gil (Portugal, hoje. O medo de existir). O pensamento deste filósofo sobre o nosso país será abordado em 2.4 . 
de guerras e sofrimentos, a verborreia generalizada...-, reveladoras de pontos de vista do narrador, serão exemplos de traços identitários dos portugueses de 2003? Veicularão uma representação credível de uma suposta identidade nacional? Será possível definir o perfil identitário de todo um povo?

Não se pode tentar delimitar identidade nacional sem ter em conta dois conceitos que lhe estão subjacentes - os de nação e nacionalismo. Nação pode ser encarada de duas formas: a de pendor marcadamente etnicista - para a qual as nações são grupos com continuidade histórica, partilhando uma língua, uma religião, uma cultura - e a de cariz essencialmente modernista que, sem negar o papel aglutinador da etnia e dos laços culturais, identifica como responsáveis pelo surgimento das nações e das ideologias nacionalistas as mudanças operadas na Europa no século XIX, em consequência quer da revolução industrial, quer da difusão de ideias propiciada pela imprensa, quer da ascensão de uma nova classe social - a burguesia. Já o nacionalismo, produto ideológico relativamente recente ${ }^{89}$, postula a integridade da "nação», considerando-a uma entidade homogénea, dotada de identidade própria. Esta perspetiva levanta muitas interrogações, sobretudo nos nossos dias, seja devido ao avanço de estudos interdisciplinares que se têm consagrado a estas matérias seja à diluição das fronteiras - mercê do avanço da globalização e da massificação a vários níveis (economia, cultura, ...).

A primeira corrente acima definida, a que defende a «nação cultural-étnica-orgânica", postula que o nacionalismo surge antes das próprias nações. A segunda, que concebe a "nação" como entidade de natureza "cívica-política-territorial», reitera a convicção de que a nação é um produto político e a identidade nacional um conceito forjado por elites. Estas apresentaram aos seus conterrâneos um património cultural e

89 A. Smith situa-o como ideologia organizada a partir do século XVIII, com as revoluções americana e francesa (1992: 55) e J. Mattoso fala da "construção de Portugal", a partir de 1880 até 1930, com a definição de símbolos identitários, como a bandeira, o hino, a comemoração do Dia de Portugal, o interesse pelo património literário e arquitetónico, configuradores de uma determinada "cultura» coletiva que recebeu a designação de Portugal (1994: 565-7). 
simbólico unificador que, efetivamente, mais não é do que o resultado de construções laboriosas com objetivos muito precisos. Na verdade, são dois pontos de vista que não se excluem mutuamente, antes se complementam (Ribeiro, 2004: 5-10, 13).

Quanto ao complexo conceito de identidade nacional, pode desenhar-se na confluência de algumas dimensões, como a partilha, por uma comunidade, quer de um espaço comum - onde se distribuem tarefas e recursos e onde todos os que o habitam se submetem a um sistema que regula direitos e deveres - quer de mitos fundadores e memórias históricas e culturais (Smith, 1992: 60). Trata-se de vetores tendencialmente estáveis - uma vez que relevam de instâncias como o território, a etnia, a economia, a praxis política e o sistema legislativo que a suporta, bem como de um fundo cultural comum -, que se congregam numa ideologia nacionalista e são transmitidos culturalmente, sobretudo pela família, pela escola e, nas sociedades crescentemente mediatizadas, pelos meios de comunicação social. A definição dessa identidade em função de um coletivo partilhado não obsta a que cada indivíduo que nela se integra assuma, nas suas vivências pessoais quotidianas, múltiplas identidades (Smith, 1992: 60-1, 67)90.

Se uma definição inquestionável de identidade nacional não encontra fundamento científico, reconhece-se a existência, no interior de cada fronteira91, de um património comum, legado centrípeto que é horizonte de referência e integra as imagens que constituem o «imaginário social» (Moura, 1998: 46). Esse imaginário partilhado alimenta a reflexão histórica, filosófica e sociológica, assim como a criação artística - literária ou

90 Acrescenta A. Smith: «(...) Sociologically, human beings have multiple identities, that they can move between them according to context and situation, and that such identities may be concentric rather than conflictual. None of this is to deny the cultural reality and vivid meaning of these identities, which, transmitted through successive generations, are not exhausted by the often fickle volitions and changing perceptions of individuals" (67).

${ }^{91}$ A definição de "fronteira" é sobretudo uma questão política, que não cabe no âmbito deste texto. Para a problemática da identidade nacional, é pertinente assinalar que Portugal é, na Europa, um caso único de nação com fronteiras estabilizadas há mais de setecentos anos, com um povo, uma língua e, até há poucos anos, uma religião comum. 
outras -, sem deixar de ser dinâmico e mutável, porque indissociável do devir histórico de cada nação ${ }^{92}$.

Em 2.4., abordarei algumas das características que parecem configurar o alegado "nacional portuguesismo", com o qual o narrador de Fantasia... mostra não se identificar, uma vez que se distancia das imagens do país que oferece ao leitor e procura despertar nele a cumplicidade de um olhar que deseja igualmente crítico. Mas vejamos, primeiro, algumas das formas como as imagens identitárias podem ser textualizadas em obras literárias.

\subsection{Estereótipo e representação social}

Como tenho vindo a referir, o ponto de partida para a minha reflexão foi Fantasia... e, na questão concreta das representações identitárias, o modo como o romance pretende espelhar os "portugueses", a "alma portuguesa", o nosso "caráter nacional». Numa obra declaradamente polifónica e polissémica, com uma estrutura pulverizada e um final equívoco, o que o leitor vislumbra são instantâneos do quotidiano que põem em evidência alguns traços impressivos do portuguesismo do século XXI, como os citados em 2.2., e que merecem o vitupério do narrador.

Sendo a literatura simultaneamente espaço de representação, de autoconhecimento e de inter-relação ${ }^{93}$, como se podem configurar nela identidades coletivas ("nós») e o confronto entre o «eu» e "os outros» (a alteridade)?

A questão é tão ampla e complexa que me vou restringir a dois conceitos operativos para a análise do romance de MC: estereótipo e representação social.

Conceito postulado por Lippmann, em 1922, na tentativa de perceber como cada ser humano configura a realidade social (Cabecinhas, 2004: 539), o estereótipo apresenta-se como um sistema de esquemas culturais

92 Para me ater a referências que se podem cruzar com o romance em estudo, evoco novamente a instalação de Joana Vasconcelos, "Portugal a Banhos», que apela a esse imaginário comum (cf. supra nota 5).

93 A todo o uso da língua subjaz a noção de um «tu» (cf. supra ponto 1.1., nota 10). 
preexistentes, crenças, atitudes, comportamentos e características de personalidade que se considera configurarem uma determinada categoria de indivíduos ou grupos sociais. Essas estruturas mentais - individuais ou partilhadas, ativas ou adormecidas - são inevitáveis e indispensáveis para categorizar a nossa perceção da realidade e para nos permitir agir sobre ela. Os estereótipos funcionam igualmente como fator de individualização ("eu» em confronto com "o outro») e/ou de coesão grupal («nós» em oposição «aos outros»), pelo que nem sempre constituem perniciosas e redutoras ideias preconcebidas que podem contaminar as relações sociais e as configurações identitárias, como as enumeradas por F. Mónica, em 2.2. Não sendo entidades estáticas, os estereótipos preservam alguma imutabilidade, nomeadamente quando estão em causa crenças étnicas e nacionais, mesmo quando elas não têm nenhuma base factual (Cinnirella, 1997: 37-9, 44-6; Amossy \& Pierrot, 2011: 28-9, 38)94.

Muito fecundo na esfera das ciências sociais e cognitivas, o conceito de estereótipo transmutou-se para o campo dos estudos literários, onde se revela também de grande produtividade no âmbito dos estudos imagológicos. A Imagologia é um domínio da literatura comparada que se consagra à análise da textualização das representações imaginárias do Outro, nomeadamente do estrangeiro. Ainda que o cerne da minha análise não sejam essas figuras estereotipadas, porque não ocupam significativamente o discurso do narrador de Fantasia..., vou recorrer a dois dos conceitos teóricos da Imagologia - estereótipo reprodutivo/produtivo e mito como intertexto -, pois servir-me-ão para uma breve referência à representação dos ciganos e dos imigrantes, bem como à recriação da figura de Mofina Mendes, que se corporizam no romance.

O olhar sobre a alteridade pode ancorar-se num de dois pólos, o ideológico e o utópico, tomados aqui em sentido descritivo. De acordo

94 Amossy \& Pierrot distinguem preconceito - atitude adotada por um indivíduo ou por um grupo em relação a um dado objeto que se revela nos seus comportamentos e tem caráter negativo - de estereótipo - imagem coletiva acerca de um determinado grupo. Enquanto o primeiro releva do campo afetivo, o segundo diz respeito ao campo cognitivo. Qualquer um dos dois pode ou não dar origem a atitudes discriminatórias (2011: 37-8). 
com J.-M. Moura, que fundamenta a sua metodologia de análise imagológica na hermenêutica de P. Ricoeur, a ideologia funciona como força de integração, uma vez que reproduz preconceitos e crenças coletivas sobre o Outro, que surge em contraponto ao grupo/à sociedade. Mantendo a alteridade confinada às expectativas comuns, o grupo/sociedade reafirma o seu próprio valor. A utopia, pelo contrário, revela-se agente de subversão: representando o Outro fora das malhas ideológicas dominantes no seio do grupo, rompe as expectativas partilhadas e encara a alteridade como singular, excêntrica (1998: 50-3). Afirma ainda J.-M. Moura que esta distinção remete para os pronomes latinos alter e alius:

"ALTER est l'autre d'un couple, pris dans une dimension étroitement relative où se définit une identité et donc son contraire. ALIUS est l'autre indéfini, l'autre de l'identité et de tout élément qui s'y rattache, mis à distance de toute association facile, l'autre utopique.»(1998: 53)

Em suma, a alteridade pode ser representada como reflexo da cultura de um grupo - alter - ou como afirmação de uma diferença radical em relação a ela, que configura um horizonte a alcançar - alius -, sendo dois fenómenos que se implicam dialeticamente (Moura, 1998: 53-4).

Como veremos em 3., no romance de MC, a imagem dos ciganos que é veiculada pelo poema recitado à beira da piscina de Bernardes - e que os dois casais assumem como atual - revela uma perceção congelada desse grupo étnico (alter). Esta minha afirmação do valor de reprodução ideológica desse estereótipo confirma a já referida relevância do papel do leitor na construção semântica do discurso literário e é corroborada por R. Amossy - a reconstrução das representações estereotipadas cabe ao leitor, a partir dos elementos disseminados no texto. R. Amossy põe também em relevo a produtividade didática da análise de estereótipos, quer em termos de competências gerais de leitura dos alunos quer no que diz respeito às competências culturais (2011: 73-5, 83-4). Na aula de PLE, a interpretação de estereótipos textualizados pode revelar-se um instrumento muito pertinente para o desenvolvimento da competência 
cultural dos discentes ${ }^{95}$. Em Fantasia..., essa imagem fixada pelo grupo acaba por ser subtilmente invertida pelo narrador ${ }^{96}$. Já no que diz respeito aos imigrantes, a obra confirma as representações coletivas de uma nova realidade social do Portugal de 2003.

Tomo ainda de empréstimo ao campo teórico da literatura comparada a noção de mito - na aceção de "Historia ficticia o personaje literário o artístico que condensa alguna realidad humana", segundo o Diccionario de la Real Academia Española de 2001 - "como un intertexto de referencia” (Cecilia, 2006: 61). Em Fantasia..., o narrador entrega-se a diversas modulações de um mito estereotipado e já literarizado - o da personagem que constrói castelos no ar e vê todos os seus sonhos de grandeza esfumarem-se, mercê da sua imprevidência: são evocados, no romance, as danças arrebatadas da Mofina de Mestre Gil e de Perrette de La Fontaine - que acabam por lançar por terra o azeite e o leite, respetivamente - e o pontapé inadvertido do brâmane que quebra o pote de farinha (14). Em 3., vai ser analisada a reatualização deste estereótipo universal, verdadeiro leitmotiv no romance, com o objetivo de perceber se e de que forma a sua omnipresença decorre da tese inicial do narrador - a da verborreia causadora de múltiplos descasos ${ }^{97}$ - e se, nessa circunstância, se reveste de um "valor simbólico e iluminador» (Cecilia, 2006: 63).

É igualmente necessário convocar a noção de representação social. A fronteira ténue entre este conceito e o de estereótipo (sendo que, para alguns estudiosos, eles se sobrepõem) é assinalada por Maisonneuve,

95 Cf. p. 25 do Quadro: «A língua não é apenas um aspecto fundamental da cultura, mas é também um meio de acesso a manifestações culturais. [...] Na competência cultural de um indivíduo, as várias culturas (nacional, regional, social) às quais esse indivíduo teve acesso não co-existem simplesmente lado a lado. São comparadas, contrastam e interagem activamente para produzir uma competência pluricultural enriquecida e integrada, da qual a competência plurilingue é uma componente que, por seu turno, interage com outras componentes».

96 Cf. J.-M. Moura: "C'est que l'appréhension de la réalité étrangère par un écrivain (ou un lecteur) n'est pas directe, mais médiatisée par les représentations imaginaires du groupe ou de la société auxquels il appartient. D'où la nécessité de travailler sur l'imaginaire social environnant l'image littéraire de l'étranger. A partir de son étude seulement, l'on pourra vérifier si l'auteur a reproduit (consciemment ou non) telle représentation globale ou s'il s'est radicalement éloigné de tout schéma imaginaire collectif pour faire acte de création et, partant, de critique du réel» (1998: 45).

97 Cf. supra Introdução. 
para quem representação social remete para um "univers d'opinions». Segundo crê, revela-se menos conotado negativamente do que estereótipo, já que este, como aliás foi acima definido, se fixa na "cristalização de um elemento" (apud Amossy \& Pierrot, 2011: 52-3).

Uma última nota, necessariamente breve, sobre os provérbios: voz anónima da doxa, condensação de um saber partilhado e enraizado culturalmente (Amossy \& Pierrot, 2011: 98), os adágios podem ajudar a construir um universo social e/ou uma personagem. Voltarei a esta questão quando analisar a personagem Maria das Dores, na terceira parte deste meu texto 98 .

É pois a um "universo de opiniões» que contribui para estruturar as representações sociais portuguesas que aludirei de imediato. Procurando encontrar algumas das linhas de pensamento que apresentam configurações do imaginário social nacional e, consequentemente, do nosso perfil identitário, quis ouvir quem tem pensado sobre estas complexas questões e manifestado publicamente a sua perspetiva crítica fundamentada.

\subsection{Olhares sobre o país}

\section{Imagens do Portugal contemporâneo}

De entre os diversos e possíveis prismas de estudo, no que à identidade nacional diz respeito, J. Medina opta pela abordagem histórico-cultural quando estuda o ethos português, afirmando: "O facto é que o heroísmo nacional e o patriotismo canónico dum dado país, como quase tudo o mais relacionado com o imaginário nacionalista, é efémero, evanescente e datado, transiente, numa palavra: histórico, isto é, sujeito à lei de bronze da metamorfose incessante e imparável dos valores de heroicidade que os povos veneram em dadas fases das suas vidas terrenas» (2006: 35 e 49).

98 Cf. supra nota 69. 
Ao mergulhar no nosso passado histórico para encontrar traços distintivos nacionais, Mattoso faz referência aos "reaportuguesadores", um grupo de intelectuais e artistas de horizontes ampliados por vivências noutros países europeus que, desde os finais do século XIX aos primeiros anos do século XX, desenvolveu uma ação artística e cultural concertada, com o propósito de arrancar o país ao imobilismo e à ignorância herdados do Antigo Regime. Por isso, segundo o historiador, muitos dos traços identitários que hoje em dia assinalamos como especificamente nossos são herança do labor patriótico desses homens, que definiram um novo "portuguesismo", e não manifestação de qualquer essência especificamente lusitana (1994: 570-80) ${ }^{99}$.

Estas duas perspetivas corroboram o que foi dito em 2.2.: a identidade nacional, ou melhor, as identidades nacionais são fluidas, transitórias, mutáveis. No romance de MC, aliás, surgem traços coletivos relativamente recentes (é preciso não esquecer que o ano de publicação foi 2003), que parecem ter começado a reconfigurar a nossa identidade - e.g., a insuportável proliferação de telemóveis (13) ${ }^{100}$, as estações de serviço dos "tempos de agora" (103-4), a invasão do espaço mediático por programas de entretenimento sem qualidade, como a imitação de telenovelas brasileiras (137-9)101.

Sem esquecer a ressalva feita sobre o imaginário coletivo, que ele classifica como "transiente», J. Medina apresenta aquilo a que chama "um certo catálogo de mitos», i.e., algumas das «imagens de marca identitárias lusas» (2006: 64), transmitidas pelas instituições que têm uma função eminentemente socializadora, como a escola e a família. O historiador não deixa de assinalar que essas "marcas totémicas [...] estão fortemente datadas [...], algumas em vias de desaparecimento inexorável da memória

99 Cf. supra 2.2., nomeadamente a nota 89.

${ }^{100} \mathrm{~J}$. Gil considera que os milhões de telemóveis que os portugueses utilizam são sinal de "territorialização gregária» (2005: 52).

101 A questão da mediocridade televisiva, aliás, já tinha sido parodiada pelo escritor, no romance Era bom que trocássemos umas ideias sobre o assunto (cf. pp. 30-1). A leitura dessa obra confirma o apreço de MC pela autorreferencialidade: aí, o narrador refere-se ao "caso do senhor bispo de Grudemil» (pp. 105ss), topónimo inventado pelo escritor e que é revisitado em Fantasia... 
colectiva" (2006: 64-5). De entre esses vários "portuguesismo(s)" (que Medina define como "um mosaico de símbolos, imagens, momentos memoráveis e hábitos de uma certa comunidade nacional, a nossa - a portugalidade», p. 302), refiro apenas, a título de exemplo, alguns dos que têm tido maior ressonância coletiva, como o mito sebastianista, a mitologia da Saudade, o pendor lírico ou o azulejo (herança árabe ou holandesa), a tendência para a sátira e a música popular (2006: 65-100). Em Fantasia..., o narrador evoca esse lastro nacional comum, nomeadamente a presença árabe no Alentejo (130), não abdicando de um humor corrosivo quando revela as novas tendências musicais - de que Soraia Marina é um epítome (21, 46, 126-7) - que causam furor entre muitos portugueses.

Antecipando o discurso directo de $\mathrm{MC}^{102}$, não posso deixar de reforçar a natureza contextual, logo transitória, dos traços identitários, verbalizada pelo escritor:

Depois, está entranhado nos costumes um ódio fanático ao silêncio. Mesmo na lonjura mais retirada, com sobreiros, giestas e estradas desencorajadoras. Lá aparecem aqueles medonhos motociclos e quadriciclos a matraquear os ares e também os rádios dos automóveis aos uivos, os foguetórios de morteirada, os estrondosos decibéis da musiqueta popular, nas festarolas, noite adentro. Creio que há quem faça equivaler o barulho a promoção social, como, aqui há uns anos, o pintalgar berrante e o azulejar das casas a demarcar-se das brancuras da pobreza.» (Carvalho, 2007a: 20)

Os azulejos assinalados por J. Medina como um dos "portuguesismo(s)", que podem carregar um lastro histórico, testemunho cultural da nossa miscigenação, são furiosamente destruídos por Eleutério e Desidério, em Fantasia..., ante a cumplicidade encorajadora de Felismina (128-30). Em tempos menos recuados, na opinião de MC, outros azulejos foram sinal de novo-riquismo nem sempre esteticamente adequado à paisagem ("há uns anos, o pintalgar berrante e o azulejar das casas a

102 Cf. infra 2.4. 
demarcar-se das brancuras da pobreza»), tentativa de afirmação social num país estruturalmente atrasado e fustigado pela indigência quase generalizada.

Reafirmo, em consequência, o caráter movente dos traços identitários de qualquer povo, antes de apresentar pontos de vista sobre a "portugalidade" contemporânea expendidos por alguns dos mais respeitados e intervenientes vultos da vida intelectual, académica, cultural e mediática do país. A necessidade de restringir a escolha é óbvia. Dentro das limitações inerentes a um trabalho desta dimensão, procurei abarcar um leque suficientemente amplo de opiniões que refletissem diversos valores ideológicos, culturais e estéticos sobre imagens identitárias relativamente recentes, de forma a poder desenhar um certo perfil nacional. Realce-se que, em momentos de crise - como o espinhoso período que Portugal, a Europa e o mundo ocidental atravessam -, as questões identitárias costumam ressurgir com particular pujança, muito propícia a distorções exacerbadas.

A abrir esta breve resenha, uma provocação de M. E. Cardoso: "Todas as palavras relevantes começam por P: Portugal; periférico; pequeno poder.». Trata-se da frase que inicia um texto intitulado "Os potentinhos portugueses», onde o autor discorre sobre a nostalgia de uma grandeza perdida e a prepotência em que se comprazem "ditadorzinhos» de trazer por casa. Segundo M.E.C., a receita para lidar com o compatriota que pretende dar-nos «um exemplinho» do que pode fazer de forma legal - o chamado "chico-esperto" (que faz pensar em Januário, de Fantasia...) - é perder o menos tempo possível com essa "pessoinha" e recorrer à dose certa de hipocrisia, pois "A hipocrisia é uma técnica de economia" (2010: 32-4). O habitual olhar corrosivo de M.E.C., sublinhado pela proliferação de diminutivos, não obsta a que ele, meio inglês e assumidamente anglófilo, proclame o seu amor ilimitado a Portugal. Numa carta aberta publicada a 10 de Junho de 2011, onde não deixa de enunciar os principais defeitos do "melhor país do mundo", declara M.E.C.: "Tu não és orgulhoso. Mas muito bem disfarçada, tens uma vaidade sem fim. Dizes-te feio e vestes-te mal mas, quando passas por um espelho, espreitas e achas-te giro" (2011: 5). 
Nas colunas de opinião ou em blogues pessoais, tendo como pretexto situações do dia-a-dia ou ecos de outras vozes, em textos mais contidos ou num registo de derisão, sobressaem as nossas piores características: o desprezo pelos intelectuais ${ }^{103}$, a procrastinação como princípio de vida ${ }^{104}$, a relação esquizofrénica que mantemos connosco próprios, já denunciada por M.E.C. ${ }^{105}$, a incivilidade quotidiana ${ }^{106}$. Como ilustração destes defeitos, no romance de MC, encontramos Bernardes e as suas opiniões sobre os escritores - «nabóides» (15) -, Maria das Dores e a eternamente adiada tese de mestrado (186), Januário como personificação do culto da aparência do novo-rico e da absoluta falta de escrúpulos (55-7 e 188-9).

A problemática da nossa autoimagem tem sido um dos focos de estudo de E. Lourenço, observador lúcido do nosso país e nome incontornável quando se fala sobre imagens do Portugal contemporâneo. "Hermeneuta do imaginário português» (Rodrigues, 2008: 1), deu à estampa, em 1978107, volvidos apenas quatro anos da mudança de regime inaugurada com a Revolução de Abril, uma obra onde se propôs fazer uma «imagologia, quer dizer, um discurso crítico sobre as imagens que de nós mesmos temos forjado» ${ }^{108}$, essencialmente a partir de textos literários (Lourenço, 2005:

103 Cf. M. A. Pina (2009): «Ninguém gosta de intelectuais, principalmente os próprios intelectuais. [...] É gente que não "age", sendo que "agir" [...] tem, ao contrário de "pensar, " enorme prestígio".

104 Cf. Alice Vieira (2009): "Tomar decisões, nem que seja a banalidade de desligar um telefone, é trabalho demasiado hercúleo para os nossos pobres ombros. Por essas e por outras é que eu venho há muito a divulgar por todos os meios ao meu alcance aquela extraordinária canção dos "Deolinda", chamada "Movimento Perpétuo Associativo".

105 Cf. R. Zink (2009): «E continuamos a ser o único povo que, genuinamente, se odeia a si próprio enquanto colectivo nacional, mas se adora enquanto pequena colectividade. No fundo somos uma feliz sociedade recreativa, um país com pés de bairro".

106 Cf. J. M. Tavares (2009): "Portugal está cheio de gajos porreiros. Mas o nacional-porreirismo não é mais do que uma declinação açucarada da velha filhadaputice. Por cada tipo que gosta de se armar em chico-esperto há nove que são obrigados a fazer figura de chicos-parvos".

107 A edição que consultei é de 2005.

108 Cf. E. Lourenço: «Imagens positivas de nós mesmos abundam na nossa memória colectiva e cultural [...]. Imagens negativas também não faltam, sobretudo a partir da crise nacional do século XIX e da descolagem fulgurante da Europa da revolução industrializada. Mas nem uma nem outras, salvo raríssimas excepções, estão isentas de preconceitos passionais» (2005: 74). 
18) ${ }^{109}$. E a descrição que faz de um povo do qual o filósofo se considera parte integrante - usa por regra a $1^{\mathrm{a}}$ pessoa do plural, ao contrário do que acontece em Fantasia..., onde o narrador se distancia da generalidade dos comportamentos dos seus compatriotas - é implacavelmente certeira: nas relações pessoais, sociais, laborais, a nível intelectual, cívico e ético, as nossas idiossincrasias são desmontadas e explanadas, fazendo nascer no leitor um travo de embaraço e impotência, pela acutilante verdade e atualidade do retrato, onde é impossível não reconhecer práticas e respetivos protagonistas.

Causas imputáveis à História nacional, à gestão política e económica da coisa pública, ao acesso à cultura, entre outras, contribuíram para moldar um ethos lusitano que E. Lourenço sintetiza em duas palavras: "hiperidentidade irrealista». Saudosos do passado áureo, ainda que efémero e inconsequente, dos Descobrimentos, o nosso percurso nacional tem oscilado entre a autoimagem hipertrofiada que nos prende a um passado mitificado (24)110 e um latente complexo de inferioridade (25), que se conjugam com uma disseminada incapacidade de agir e de mudar o "destino" coletivo"11. A dissociação de personalidade de que parecemos padecer tem sido uma constante que nem os sucessivos traumas nacionais abalaram (desde o Ultimatum inglês de 1890 à perda súbita, em 1974, de um Império que de facto nunca existiu) ${ }^{112}$. Uma «inconsciência colectiva»

109 Sempre que as citações se referirem a esta obra de E. Lourenço, limitar-me-ei a indicar, entre parênteses, as páginas citadas.

110 Também M. Clemente considera que os Portugueses mantêm com o seu país uma relação "bíblica», na medida em que se sentem eleitos e destinados a "uma missão universal." O declínio de Portugal acabou por gerar "algum auto-ressentimento", sendo que "Todos nos embebemos de um Portugal que não achamos"(2009: 10-1). Acrescenta que "a melhor ideia que temos de nós próprios provém da poesia e não da prosa. Desta última guardamos sobretudo o que nos distancia de nós próprios, entre a ironia e o sarcasmo. Pensamo-nos mais altamente à maneira de Camões do que à maneira de Eça. [...] Quando nos relacionamos bem com Portugal, fazemo-lo com um país mais sentimental do que mentalmente definido, como se a espuma das ondas nos toldasse a visão» (14).

111 Em meados do século XX, escreveu M. Torga: "Eufóricos, porque justificados, vimo-nos por algum tempo legítimos cidadãos do mundo". Depois do apogeu, "esquecemos a lição". Enquanto a Europa tomou o caminho do progresso, nós ficámos «a cantar, ao som duma guitarra, loas à fatalidade» (2007: 98-9).

112 A propósito da reação portuguesa ao Ultimatum inglês de 1890, escreve E. Lourenço: «Passado o momento da aflição patriótica, percorrido até ao absurdo o labirinto sem saída 
(46) que revela um povo ausente de si mesmo e feliz com essa ausência (48) ${ }^{113}$. Bajulação e maledicência sarcástica, arrogância e fragilidade, imprevidência e providencialismo, crendice e imobilismo, conformismo e ignorância, dissimulação e quotidiano ostentatório, provincianismo bacoco que idolatra tudo o que vem do estrangeiro, mesquinhez e inveja, inércia e inépcia. Traços que se revelam no absentismo cívico, numa imprensa acrítica, na res publica à mercê do caciquismo, num desenvolvimento científico e tecnológico incipiente, numa vida cultural reservada a minorias, num modus vivendi onde o Parecer sobreleva o Ser ${ }^{114}$. Afirma E. Lourenço que, se "Nenhum povo [...] pode viver sem uma imagem ideal de si mesmo" (51), é urgente que desmistifiquemos a que inventámos para nós, que nos olhemos no espelho nacional com um "olhar sujeito" (79) e, sem artifícios, assumamos a responsabilidade de mudar. Uma alteração desta natureza - que permita um olhar crítico e a construção de uma sociedade verdadeiramente democrática e não do V Império eternamente almejado mas nunca cumprido ${ }^{115}$-, é indissociável de uma "conversão cultural de fundo"(52).

da nossa impotência, voltámos à costumada e agora voluntária e irrealística pose de nos considerarmos, por provincianice incurável ou despeito infantil, uma espécie de nação idílica sem igual» (2005: 31). É impossível ler estas palavras de uma lucidez extraordinária sem pensar na comoção nacional provocada pela notação da Moody's que, em Julho de 2011, classificou Portugal como "lixo»: depois de várias semanas de desânimo coletivo, devido à grave crise económica e financeira do país, essa avaliação difundida nos mass media do mundo inteiro desencadeou uma forte comoção nacional. Inúmeros grupos de cidadãos mobilizaram-se para mostrar o seu veemente protesto, que se concretizou, e.g., em ataques informáticos e no envio de lixo à agência financeira. A agência de rating americana tornou-se o bode expiatório oportuno, que volatilizou o discurso anterior sobre a nossa responsabilidade cívica, individual e coletiva, na superação dos graves problemas estruturais que nos afetam. Em 2009, L. Jorge encontrou a palavra "lixo» escrita na placa de Portugal, quando chegou da Galiza, e escreveu: «Para nós, identificar a pátria como lixo parece ser uma forma pacífica de nos autodestruirmos» (2009: 16). Já em 2008, M. A. Pina concluíra que somos um "país ciclotímico», uma espécie de "bipolar de Mr. Hide e Dr. Jekyll».

113 Tal como as personagens de Fantasia..., felizes na sua mediocridade ensurdecedora.

114 Dir-se-ia o retrato de Januário (cf. caracterização feita por Lencastre, nas pp. 188-9). Esta questão será retomada em 3.

115 Refletindo sobre questões políticas, depois de afirmar que «Portugal não é um país fácil de governar...», E. Lourenço afirmou, em 2010: «E daí, talvez, que o país esteja sempre em estado sebástico, à espera de um salvador, quer seja um partido, quer seja uma personagem. O Sidónio Pais na República ou o Salazar. É uma espécie de nostalgia perversa que reemerge de cada vez que há uma crise: ah, se estivesse aqui, realmente, um homem forte! 
O essencial desta arguta perceção da imagem dissonante que os portugueses fazem de si próprios mantém-se atual: ainda que, já em 2000, E. Lourenço tenha afirmado que o imaginário cultural português estava em mutação - porquanto a imersão numa cultura padronizada globalmente fez deslocar a nossa "mitologia cultural", antes de "essência literária", para novos domínios criativos como as artes plásticas, as cénicas, a música, entre outras -, é por ele reiterada, nesse mesmo texto, a noção de que a cultura portuguesa "é intrinsecamente desdramatizante» (2000: 20-2). Talvez por isso a desdita de Mofina Mendes ecoe em vários tons no romance de MC sem que nenhuma aprendizagem resulte, para as personagens, de tantos e sucessivos sonhos desfeitos: "O trágico propriamente dito repugna-lhe ou, sabiamente, recalca-o» (Lourenço, 2000: 22)116.

"Sempre saltitando, em trânsito permanente para parte nenhuma" (Gil, 2005: 53)117: esta citação de J. Gil - pensador que também se tem consagrado à reflexão sobre a identidade nacional - resume uma mescla de alheamento, omissão, resignação, por vezes acompanhada de uma "fuga para a frente" que o filósofo, dois anos depois da publicação de Fantasia..., qualificou como "não-inscrição", ausência de ação cívica efetiva, de responsabilidade, autonomia e maturidade: «Nada tem realmente importância, nada é irremediável, nada se inscreve» (18). Este "medo de existir»118, vivência infantilizada e norteada pelo relativismo de valores, contamina os portugueses. É terreno fértil para a proliferação da "esperteza saloia" e do "carapau de corrida" (19) - vícios alimentados pela falta de um espaço público onde se exerça livremente uma ação crítica (25) - e origina a seguinte síntese de J. Gil: «Somos

[...] Não há uma representação simbólica de Portugal à altura da nossa própria História. Quer na ordem interna, quer na ordem externa" (Sousa, 2010: 4-5). Também M. Clemente alude às "saudades do futuro", produto da nossa veia messiânica (2009: 14).

116 A propósito de Era bom que trocássemos umas ideias sobre o assunto, escreve $\mathrm{E}$. Lourenço sobre MC: «Muito à portuguesa, sem traumatismo, muda um dos cenários mais revisitados da nossa ficção [...]. Ninguém como Mário de Carvalho desdramatizou este universal fenómeno do desencanto ideológico, tomando-o como matéria lúdica e até irónica» (2000: 22).

117 Neste ponto, sempre que me referir a esta obra de J. Gil, limitar-me-ei a indicar, entre parênteses, as páginas citadas.

118 Cf. supra nota 88. 
[...] os melhores exemplos europeus de arcaicos pós-modernos" (33). O teor das nossas idiossincrasias que aí são enumeradas não está fundamentalmente longe da perspetiva de E. Lourenço e, creio, pode suscitar em qualquer cidadão responsável e preocupado com o nosso destino comum uma angústia identitária semelhante à desencadeada pelas palavras do ensaísta que observa Portugal do voluntário exílio francês: a falta de um "espaço de dessubjectivação e criação" (32), que esconde um sentimento de inferioridade e se procura compensar com projetos megalómanos (58) - a hiperidentidade diagnosticada por E. Lourenço -; a carência moral, democrática e intelectual; a superficialidade e o gosto pela mediania ${ }^{119}$; a incapacidade de manter um diálogo construtivo, porque os portugueses não sabem ouvir nem aprofundar as questões ${ }^{120}$. É impossível não pensar nos «dez milhões de íncolas a querer saber onde é que os outros param, e a transmitir pensamentos à distância» (Fantasia..., 13), quando se lê J. Gil, que condena "a visão curta" e a "territorialização gregária» (52) que os seus concidadãos revelam ${ }^{121}$.

Duas facetas da nossa identidade denunciadas nesse texto de 2005 - a fuga dissimulada às leis, que fomenta a corrupção, eufemisticamente designada como "desenrasque» (84-5), e o "burgessismo" que tantas vezes lhe está associado (105) - são desenvolvidas no ensaio que o filósofo publica em 2009. Segundo explica, o chico-esperto é, para os lusitanos, sinónimo de esperteza, do descaramento que reverte as situações a favor do protagonista, que acaba por usufruir de uma extraordinária impunidade mercê do silêncio tácito e, frequentemente, da admiração que as suas práticas corruptas acabam por concitar nos outros. Considera J. Gil que se trata de uma característica inerente à

119 Cf. J. Gil: «O português revê-se no pequeno, vive no pequeno, abriga-se e reconforta-se no pequeno" (2005: 51).

120 Cf. J. Gil: «Os portugueses não sabem falar uns com os outros, nem dialogar, nem debater, nem conversar» (2005: 55).

121 Referindo-se aos telemóveis que pululam no país, J. Gil verbera a «algazarra insuportável, com todos a falar ao mesmo tempo, cada um com a sua veemência particular sem dar a devida atenção aos outros, seus "interlocutores" (2005: 56). Esta opinião do filósofo foi já referida (cf. supra nota 100). 
forma como os portugueses se sociabilizam e que acaba por os agrupar em dois universos: o dos chicos-espertos e o dos «idiotas honestos e seguidores estúpidos das leis» (2009: 30-5) ${ }^{122}$. O nosso problema maior, sintetiza, reside no facto de sermos portugueses «antes de sermos homens» (2009: 10).

Nenhum dos dois pensadores portugueses que acabo de referir mais demoradamente se arroga a prerrogativa de proferir juízos inquestionáveis sobre um suposto ethos português. Não obstante, considero que ambos contribuem, com o seu saber informado e amadurecido, para um pensamento crítico sobre questões identitárias e para a configuração de representações sociais portuguesas. Os traços essencialmente negativos que apontam como vícios estruturais dos seus (nossos) conterrâneos não serão exclusivos de Portugal, mas revelam-se fulcrais para a nossa reflexão enquanto comunidade nacional e, eventualmente, para a nossa sobrevivência, enquanto nação ${ }^{123}$.

A encerrar esta resenha sobre imagens identitárias, vou agora focar a minha atenção em MC. Ainda que, para a apreensão semântica de um texto, nos devamos concentrar nas «intenções virtualmente contidas no enunciado» e não nas "intenções do sujeito empírico da enunciação" (Eco, 1993: 66), as coordenadas contextuais em que uma obra foi escrita não podem ser ignoradas ${ }^{124}$. Um escritor atento e informado, como o autor de Fantasia..., que escreve um livro cujo protagonista é Portugal, não está certamente alheado das grandes questões que dizem respeito ao seu país e aos seus concidadãos.

122 Cf. supra nota 106.

123 L. Cunha critica a visão essencialista de identidade nacional e, a propósito de alguns dos textos que a têm refletido (e.g., segundo ele, o de 2005 de Gil), afirma: «Esta projecção uniforme de uma representação do português transporta consigo processos de reificação da identidade nacional [...]. Fortemente auto-referenciais, eles constroem uma narrativa eficaz, quer dizer, reconhecida e reproduzida socialmente», transmutando em traço natural características que são um produto cultural (2006: 5-6).

124 Cf. U. Eco: "Contudo, não pode dissimular-se o peso adquirido pelas circunstâncias da enunciação, contribuindo para a formulação de uma hipótese sobre as intenções do sujeito empírico da enunciação ao determinar a escolha de um Autor-Modelo. [...] A configuração do Autor-Modelo depende dos traços textuais, mas põe em jogo o universo do que está por detrás do texto, do destinatário e, provavelmente, também antes do texto e do processo de cooperação" (1993: 68 e 69-70). 


\section{Mário de Carvalho em discurso direto}

Aquando da publicação de Fantasia..., Mário de Carvalho contava já com mais de dezena e meia de obras publicadas (romance, novela, conto, texto dramático, guiões para televisão e cinema, artigos de opinião) e vários prémios atribuídos. Os seus textos literários foram objeto de recensões críticas e de estudos académicos e o escritor concedeu várias entrevistas, nestes últimos anos, a pretexto da publicação de títulos originais ou da atribuição de novos galardões. Foram alguns desses textos em discurso direto que percorri, com o intuito de perceber o que pensa MC sobre o seu país e os portugueses, uma vez que o próprio escritor confessou, numa entrevista: "As minhas preocupações não podem deixar de estar presentes nos livros que faço» (Cotrim, 1996, p. 46).

Pela relevância do conteúdo para a temática deste trabalho, escolhi catorze textos: dez entrevistas - publicadas na imprensa em papel (generalista ou especializada) ou em suporte digital - concedidas desde 1995, ano da edição de Um deus passeando pela brisa da tarde, romance histórico que viria a ser distinguido com três prémios ${ }^{125}$, até 2010 (duas são anteriores a 2003 e quatro relativas ao romance em estudo); um texto de 2003, publicado na revista Visão, porque incorpora discurso direto do escritor; e três artigos assinados por MC, todos publicados no Jornal de Letras (em 1995, 2007 e 2009).

Os textos em causa abarcam uma amplitude temporal considerável (quinze anos) e, ciente do risco a que se expõe toda a citação que é privada do seu contexto de enunciação - matéria, aliás, explanada em 1. -, tive particular cuidado em não desvirtuar o sentido dos excertos que transcrevo.

$125 \mathrm{MC}$ tinha já sido distinguido com vários prémios literários, atribuídos às obras $O$ Livro Grande de Tebas, Navio e Mariana (1982), A Paixão do Conde de Fróis (1986) e Quatrocentos mil sestércios, seguido de O conde Jano (1991). Fantasia... recebeu, em 2003, o Prémio PEN Clube Português e, em 2004, o Grande Prémio de Literatura ITF/DST.

Estas informações foram colhidas na edição de 2003 do romance e nos seguintes endereços eletrónicos:

http://penclube.no.sapo.pt/pen_portugues/premios/premiados_ficcao.htm

http://www.dstsgps.com/upload/docs/GPL/HistorialGPL10.pdf 
Os textos anteriores a 2003 partilham três eixos temáticos que acabam por se revelar recorrentes na mundividência de MC: uma consciência história aguda, que o leva a valorizar o legado cultural - sobretudo literário - de que se sente depositário ${ }^{126}$, a perceção de que a sociedade está a construir um novo modelo de vida que menospreza a inteligência, a reflexão crítica e essa espessura da tradição ${ }^{127}$ e a convicção de que apenas a cultura humanista pode resgatar o ser humano da obscuridade geradora de violências de vária ordem ${ }^{128}$. A atitude de MC perante este estado de coisas oscila entre algum desencanto e o ponto de fuga que, enquanto escritor, a veia satírica lhe permite (Cotrim, 1996, p. 46).

Após a publicação de Fantasia..., o foco dominante nas entrevistas, ponto de partida recorrente das perguntas dos jornalistas, é o olhar cáustico e desiludido que o romance traduz. MC reconhece-se pouco otimista ao afirmar que "o país está alienado" (M. João Martins, 2003: 10), aproveitando para reiterar a influência deletéria do futebol e da televisão e lamentar a confrangedora pobreza vocabular da maior parte dos seus compatriotas: "Dá impressão que há qualquer coisa de reles, de baixo, avacalhante, ajavardante, que vai impregnando camada social após camada social» (Faria, 2003: 7)129. Neste ambiente - denuncia florescem os velhacos, os patos-bravos e os videirinhos (S. Luís, 2003: 176). A verborreia nacional é causadora de grandes desmandos e,

126 Cf. as seguintes declarações do escritor: "Atrever-me-ia a dizer - embora sempre com a reserva que merecem estas afirmações absolutas - que a pedra-de-toque que permite distinguir, logo ao primeiro contacto, um bom dum mau livro é a ressonância nele destas vozes que vêm de trás" (Carvalho, 1995: 16); “(..) Antes de sermos nação, isto tinha sido um caldeamento muito grande de povos e civilizações. Por detrás de nós, há toda uma estrutura histórica" (Cotrim, 1996: 44); "As minhas deambulações pela história são uma resistência contra a lobotomização, a lembrar que não nascemos ontem» (C. O. Martins, 2004: 40).

127 Cf. o seguinte excerto de uma entrevista que concedeu: «Estamos talvez a atravessar um período de barbarização, em que as consciências são comandadas pelas grandes televisões. Muita gente pensa que está imune a isso, e acaba por não estar» (Venâncio, 1995: 17).

128 Cf. as palavras de MC: "O humanismo é a única forma de nos opormos ao assédio dos monstros e dos fantasmas" (Cotrim, 1996, p. 49). A mudança de paradigma da nossa "mitologia cultural", anteriormente de "essência literária", foi identificada por Lourenço, em 2000, como já salientei.

129 Cf. supra nota 101. Em textos posteriores, a influência perniciosa das televisões não deixou de ser denunciada pelo escritor (e.g., Carvalho, 2009: 27, ou J. Silva, 2010: 55). 
devido à ausência de massa crítica, continuam a vigorar um esquema intelectual e práticas culturais terceiro-mundistas, perpetuados por «uma gigantesca máquina de produção de analfabetos» (C. O. Martins, 2004: 40, 42-3) ${ }^{130}$.

Homem assumidamente de esquerda, consciente da importância do recolhimento reflexivo, Mário de Carvalho milita pelo espírito crítico ${ }^{131} \mathrm{e}$ por uma cidadania empenhada, que ajude a combater o desencanto, nem que seja pela derisão: "Acho que o riso é uma forma de resistência. [...] $O$ riso tem sempre qualquer coisa de desafiante e subversivo" (Marques, 2010: 34).

A obra literária instaura a sua própria referencialidade intratextual, mas não é menos verdade que muitas vezes parece aproximar-se do quotidiano. Já em 1996, fazendo referência à transfiguração da realidade que é sempre operada pelos códigos literários (cf. infra epígrafe de 3.), MC explicava como the era fácil absorver ambientes, gestos, falas do seu quotidiano para depois construir personagens e cenários credíveis e expressivos (Cotrim, 1996: 43-4, 48). E, em 2004, afirmou numa entrevista:

Convém insistir em que não escrevo com uma grelha de símbolos e de efeitos calculados. Deixo as personagens viver dentro da escrita. As intenções do autor pouco contam. Importa muito a maneira como os leitores conformam o texto. De certeza que, se daqui a trinta anos alguém encontrar este livro [...] terá interpretações completamente diferentes sobre aquilo que lê. Também um leitor australiano ou nepalês o leria de maneira surpreendente. (C. O. Martins, 2004: 42)

130 A opinião de MC não parece ter mudado desde a altura em que proferiu essas afirmações: "Lendo os jornais percebe-se que a sociedade é dominada por esta dialéctica malandro-lanzudo, do tipo ao mesmo tempo abrutalhado e chico-esperto. Houve uma série de interesses que abocanharam o país, depois de se ter aberto um período de esperança... Essa moscambilha tem transformado o país num lugar quase inabitável" (L. Duarte, 2010: 12).

131 Cf. o seguinte excerto da já citada entrevista a J. P. Cotrim: «Não gostaria de me apresentar como um pessimista jeremiante e lamuriante. [...] O pessimismo inibe a acção e pode levar a um conformismo muito perigoso" (1996: 45-6). 
$\mathrm{E}$, antes de terminar, lança uma provocação:

Quanto à função do escritor, é escrever, o melhor que for possível. E, a latere, aproveitar as entrevistas para endireitar o mundo.» (C. O. Martins, 2004: 43)

Constatamos, pelas palavras de MC, que o olhar e a voz críticos que mantém sobre Portugal entroncam em vários dos traços identitários referidos anteriormente e convocam novamente a questão da relação entre o texto literário e a realidade, referidas no início desta segunda parte do meu trabalho. O homem com existência empírica, amargamente crítico do seu país ${ }^{132}$, não é ontologicamente assimilável ao narrador de Fantasia..., nem o Portugal aí representado - malgrado as "pontes" que, enquanto leitores, consideremos poder lançar entre o romance e o retângulo lusitano ${ }^{133}$ - é o Portugal de existência real.

Como conciliar, então, todas estas vertentes aparentemente incompatíveis?

Uma identidade nacional que não se pode definir inequivocamente $v s$ um conjunto de traços partilhados - e.g., língua, memórias históricas, tradições culturais - que cimentam a coesão, estimulam a noção de pertença e contribuem para a definição de um perfil identitário, enraizado no espaço e no tempo, que se afirma muitas vezes em contraponto com o de outras comunidades nacionais ${ }^{134}$.

A assunção da diferença entre a realidade (que é resultado da apreensão subjetiva de cada sujeito histórico) ${ }^{135}$ e a imagem que dela se plasma num texto literário, muitas vezes em busca da verosimilhança aristotélica.

132 Cf. palavras do escritor, a propósito de Fantasia...: «A voz dominante é a da alarvidade» (Coelho, 2003: 6). Em 2009, questionado sobre a intenção de criticar o país neste romance, respondeu: "Talvez seja uma forma de devolver uma certa verdade através da ficção" (Palouro, 2009).

133 Cf. entrevista que MC concedeu em 2010: «O facto de se criar um mundo paralelo não quer dizer que não se criem também janelas e pontes para o mundo em que vivemos» (L. Duarte, 2010: 11).

134 Cf., em Fantasia..., os ciganos e as imigrantes de Leste.

$135 \mathrm{Na}$ perspetiva construtivista, cada texto é uma forma de construir e orientar o nosso olhar sobre o mundo pela mediação da linguagem. A abordagem pós-moderna considera ser impossível apreender a realidade: na verdade, é o discurso que confere estrutura ao caos que a realidade configura (sobre esta questão, cf. síntese de A. Rigney, 2007: 415-7). 
A consciência da existência de circunstâncias empíricas que recortam quer o contexto de produção de uma obra literária quer a atividade de receção crítica $v s$ a afirmação de que todo o contexto é "context-free" (Silva, 2010: 231) $)^{136}$.

Em consequência, todo o pensamento crítico apresentado - mesmo o de MC - é contextual e subjetivo, assim como as interpretações de Fantasia... a que vou fazer referência no início do ponto seguinte. Não são chaves inequívocas de leitura, mas constituíram, para mim, referências relevantes para a que vou apresentar e decerto já se influenciaram reciprocamente.

Sobre esta questão essencial para a análise literária, escreve Aguiar e Silva:

Em relação ao texto lido, o leitor não pode elidir, ou colocar entre parênteses, a sua exotopia e a sua exocronia, pois que é nelas e mediante elas que existe como leitor. A compreensão de um texto é sempre um evento histórico e por isso a iteração de um texto (ou de um fragmento textual) gera forçosamente significados distintos. (Silva, 2010: 231-2)

As duas primeiras partes da minha pesquisa visaram fundamentar teoricamente a abordagem crítica que pretendo fazer de Fantasia...

O que vou explanar a seguir é como, na minha ótica, através do movimento dialético entre representação/apreensão subjetiva da realidade e mundo ficcional de contornos verosímeis, o narrador logra demonstrar a tese que enuncia nas primeiras páginas do romance, orquestrando, pela voz, um país que, segundo creio, também se assemelha a Portugal.

136 Cf. Aguiar e Silva: «(...) Nenhum contexto pode ser cerrado ou rigidamente delimitado, nenhuma descrição de contexto pode ser saturada. Qualquer factor contextual remete, em reverberações e difracções intérminas, para outros factores contextuais (e o mesmo se diga dos factores intertextuais). [...] Os contextos, semiosicamente, são sempre contextualizações construídas pelos intérpretes, ou seja, pelo autor e pelo leitor, no âmbito da criatividade dos jogos linguísticos e da sua interacção com formas de vida» (2010: 231). 


\title{
3. MODULAÇÕ ES DE PORTUGAL EM FANTASIA PARA DOIS CORONÉIS E UMA PISCINA, DE MÁRIO DE CARVALHO
}

\author{
Aliâs, os romances não se fazem com realidades, fazem-se com \\ fantasias, não se fazem com "eus" verdadeiros, fazem-se com "eus" \\ falsos.
}

Mário de Carvalho [entrevista a Cotrim, 1996]

Considerada pela crítica como a melhor obra literária publicada em Portugal em 2003 (Besse, 2004) e uma das mais divertidas (Viegas, 2003) ${ }^{137}$, Fantasia... é um romance já profusamente analisado sob diversas perspetivas, que ressaltam a hibridez de género - tributária do pós-modernismo ${ }^{138}$-, a polissemia do título ${ }^{139}$, a espessura intertextual,

137 P. Mexia escreveu, no Diário de Notícias: «(...) Neste livro estamos sempre solidamente no domínio do literário, mesmo se com uma espantosa atenção ao mundo. Não me lembro de nenhum outro romance que mencione Petrónio e o Aki» (s.d.).

138 É pela voz do tio de Emanuel que a questão é chamada ao romance: «De resto, esta é uma narrativa contemporânea - acho eu - que desconfia dos acasos e das causalidades manipuladas..." (Fantasia..., p. 82). M. G. Besse considera que, neste romance, se cruzam características "ao gosto do paradigma pós-moderno" como a militância ideológica, a autorreflexividade, a implosão do conceito de verdade, as interpelações ao leitor e a reflexão metaficcional, o tom paródico e o diálogo intertextual (Besse, 2004: 13-4; cf. também C. O. Martins, 2007: 264). Questionado a este propósito, MC declarou: «Vale o que valem as etiquetas e os carimbos. Servem para comodidade de conversação e de exposição" (Santos, 2009: 268).

139 O escritor reconheceu ter-lhe ocorrido a ressonância musical do título: «Tinha acabado de escrever um livro irrequieto, irregular, rebelde aos preceitos habituais da construção narrativa, cheio de derivas, alçapões, jogos com a perspectiva e o ponto de vista, também 
muitas vezes de ressonância clássica, o diálogo permanente com diversos domínios artísticos (e.g., a pintura, a música e o cinema ${ }^{140}$ ), o caráter simultaneamente irónico, lúdico, paródico e ferozmente satírico, que o transformam num retrato trágico-cómico do país ${ }^{141}$ : «É Portugal ao espelho» (C. O. Martins, 2007: 271), um país que fala sem parar, mas não comunica. A estrutura caleidoscópica do romance é sugerida pelo próprio título - Fantasia... - e reiterada pela classificação de "cronovelema" feita pelo narrador ${ }^{142}$. Trata-se de um conceito cuja paternidade se deve a MC, que o explica da seguinte forma:

(...) Uma narrativa que participa de vários géneros de escrita - novela, crónica, cinema e até poesia [onde abundam] mudanças de plano que sugerem uma montagem cinematográfica.» (M. João Martins, 2003: 12) ${ }^{143}$

Em suma, prefigura-se uma obra estruturalmente polifónica, cujo epicentro se situa algures, no Alentejo, onde o quotidiano de dois coronéis reformados é pretexto para uma viagem de revelação identitária de um

com a própria linguagem, e pareceu-me adequado lembrar as composições musicais fluidas, soltas e livres» (C. O. Martins, 2004: 40).

140 Para além de técnicas cinematográficas, como as mudanças de plano e os flash-backs, e de referências explícitas (cf. infra nota 161), veja-se o "happy ending", em que Nelson se lança nos braços do pai (Piçarra, 2008: 54).

141 Os textos críticos sobre Fantasia... realçam a herança clássica, bem como a crítica social (denúncia do novo-riquismo, do culto pacóvio das aparências, da tagarelice ampliada pelos milhões de telemóveis usados no país, da alarvidade futebolística, da incivilidade generalizada, da inépcia mediática e da mediocridade cultural, da exploração dos imigrantes de Leste), evocando o preceito latino Ridendo castigat mores, e ainda o extraordinário labor linguístico. Sobre esta questão, cf. Guerreiro (2003), Besse (2004), I. M. Duarte (2004), Seixo (2004), Agripina Vieira (2004), Mendes (2005), C. O. Martins (2007) e Santos (2009).

142 Cf. Fantasia..., p. 34: «Este em que flanamos - chamemos-lhe cronovelema - propõe-se narrar».

143 A designação é retomada por MC em A arte de morrer longe (2010) e novamente definida por ele como um texto onde se plasma uma estratégia narrativa do século XXI (Marques, 2010: 35). O peculiar tratamento do tempo que nele se concretiza é sugerido, em Fantasia... - "(...) Mas que é o tempo para nós, viajantes do vocabulário, da semântica e da real fantasia?» (19) -, e configura uma "viagem literária pelo tempo" (Santos, 2009: 150) e pelo espaço, que permite o confronto entre duas realidades culturais bem distintas: a de que somos depositários, cuja memória alguns se esforçam por preservar e transmitir, e a que atualmente prolifera, envenena o espaço público, pujante de mediocridade. Aliás, como conclui Pacheco Pereira, "O mal destes hábitos de frequentar os antigos é ser-se dado à analogia” (Pereira, 2011). 
país outrora conquistador de mares à escala planetária e agora reduzido a "nação estreita e de horizontes apertados" (Santos, 2009: 182-3), de que é símbolo a piscina de Bernardes que desfigura a paisagem. Ao pensar num texto literário para estudar a relevância do RD na configuração de imagens identitárias nacionais, como as referidas no ponto 2.4., e tendo em vista a pretendida aplicação didática, Fantasia... apresentou-se como um desafio, pela premissa anunciada nas páginas iniciais ${ }^{144}$ : a vozearia que domina Portugal multiplica-se, dissemina-se, está na origem de múltiplos descasos, contamina a vida quotidiana e paralisa o país, coarta o espírito crítico e de cidadania, a criatividade, o bom gosto, o verdadeiro progresso. Logo num primeiro contacto com a obra, o leitor mais desprevenido apercebe-se de que essa algazarra, alimentada pela maioria dos habitantes lusos, insuportável apenas para uma minoria (na qual se integra o narrador $)^{145}$, toma corpo numa proliferação de personagens tagarelas ${ }^{146}$. O ruído estéril que elas produzem parece até contagiar a estrutura da obra: o leitor embarca num périplo por vezes vertiginoso, onde lhe é dado assistir a uma inesperada explosão discursiva, formada por pequenos episódios focados pela lente impiedosa do narrador, à maneira de sketches cinematográficos, que não raras vezes surpreendem o leitor e o fazem questionar sobre a sua real função na trama romanesca ${ }^{147}$.

Esta última parte do meu trabalho é consagrada à análise do modo como a tese do narrador se operacionaliza no romance através dos

144 Cf. supra Introdução.

145 Esta tomada de posição do narrador vai ecoando ao longo da obra: por exemplo, depois de, na p. 26, afirmar que o encontro entre dois faladores resulta amiúde na tentativa de se interromperem mutuamente, na p. 88, a propósito do tio de Emanuel, reivindicando "O privilégio autoral", o narrador assume a intenção de denunciar os «empedernidos faladores contra quem esta modesta obra se insurgiu".

146 No início da tarefa de registo das vozes presentes em Fantasia..., recenseei mais de quatro dezenas de personagens diferentes.

147 I. M. Duarte refere o enredo "talvez, com pouco que contar" e a possibilidade de se encarar Fantasia... como um romance "descosido" (2004: 3). Durante a elaboração do trabalho, interroguei-me se essa derrogação da coerência narrativa - eventualmente para além do que seria expectável num "cronovelema" - não teria sido intencional, com o objetivo último de harmonizar forma e conteúdo. Seguindo o conselho avisado do mocho de Fantasia... - "(...) Se perguntas a ti mesmo, responde-te a ti mesmo" (39) -, a única resposta honesta que posso dar é: Não sei, talvez. 
mecanismos de reprodução de palavras, tentando compreender como os "eus" falsos referidos pelo escritor ${ }^{148}$ se revelam pelo discurso e se tornam, por essa via, peças fundamentais do imenso tabuleiro nacional que Fantasia... configura, manipula e critica. A minha perspetiva de análise, consequentemente, é a da voz: procurarei demonstrar como o país barulhento e estéril é também metonimicamente representado por ela e como esse novo traço identitário português do início do milénio se plasma em RD. No fundo, pretendo identificar qual "a palavra exacta» reproduzida por esses mecanismos citacionais e interpretar o valor que adquire no romance, ajuizando dos recursos de que o narrador lança mão para abrir "a caverna do tesouro" (Fantasia..., p. 155) e revelar um país que o desencanta. O cuidado com a linguagem do romance, onde existe "uma proliferação de vozes trabalhadas com realismo apurado", foi salientado por I. M. Duarte, que se confessou seduzida "pela atenção fina ao real da língua nos seus usos concretos». Sobre a apropriação que MC faz dos mecanismos de RD, afirma ainda a linguista estar presente "uma maleabilidade, uma flexibilização máxima [...] que vem de Eça» (Duarte, 2004: 1-2).

Explicitarei primeiro as regras que defini para o levantamento e tratamento dos modos de RD no romance e, em seguida, apresentarei os dados quantitativos obtidos e uma breve apreciação dos casos heterodoxos de relato de palavras; finalmente, farei uma apreciação da funcionalidade das vozes que se soltam na criação de um determinado espaço social e cultural português, tendo em conta a tese da vozearia nacional, já mencionada.

$O$ registo inicial das palavras das personagens foi feito numa grelha com as seguintes entradas: página, personagem, transcrição da fala, tipo de $\mathrm{RD}$, forma do verbo introdutor e infinitivo desse verbo. Sempre que me pareceu relevante para a caracterização das vozes, transcrevi também o discurso atributivo.

Atendendo à profusão de caracteres ficcionais, tive de fazer escolhas para o registo - decorrentes do objetivo de procurar imagens do

148 Cf. epígrafe de 3. 
país nas palavras citadas -, pelo que me restringi às seguintes vozes: como peças fulcrais, a claque de futebol (personagem coletiva), Amílcar Lencastre, Maciel Bernardes, Desidério, Eleutério, Emanuel Elói, Angelina, Felismina, Irina, Januário, Maria das Dores, Maria José, Nelson, Neusa, Sandra, Tiago, o tio de Emanuel, o melro e o mocho. Sob a designação de "Jornalistas", considerei quer as citações de publicações periódicas $(110,113)$ quer os discursos dos dois profissionais da imprensa escrita que interagem com Emanuel - a estagiária Tânia e o jornalista de Beja (208-10) -, pois servem uma intenção crítica do narrador que será oportunamente analisada. Recorrendo à metáfora do xadrez, a que já fiz referência ${ }^{149}$, "Outras vozes" aglutina os peões, personagens indispensáveis na construção do espaço social que o narrador pretende desenhar. Devo acrescentar que tive igualmente em conta o discurso do narrador, sempre que ele cita claramente palavras alheias - em ilhotas textuais ${ }^{150}$ ou em transcrições completas, geralmente entre parênteses e/ou entre aspas ${ }^{151}$-, interpela o narratário ou dialoga com algumas das suas criações ficcionais. O narrador entra no jogo dramático: o seu discurso torna-se caixa de ressonância de várias vozes (anónimas ou não) e entabula uma longa conversa com cada uma das duas principais personagens femininas (175-8, 182-7). Esta dimensão metalética do romance, configurada em DD, vai assumir uma inesperada relevância quando é Maria das Dores que está em cena. Pelo facto de, em Fantasia..., as narrativas encaixadas serem recorrentes, optei por considerar de forma diversa a reprodução de palavras resultante das trocas comunicativas entre personagens ou dos seus pensamentos da que é relativa ao nível hipodiegético, no qual Amílcar Lencastre, Maciel Bernardes, Emanuel Elói e o melro que habita a oliveira do monte dos Lencastre assumem a função de narrador. Se, na primeira situação referida, cada intervenção

149 Cf. supra nota 85.

150 Cf. supra nota 57. Por exemplo, em ocorrências como esta: «O que o homem disse não foi "trá-lo", de acordo com a gramática, mas "trázio!", de acordo com os seus hábitos" (Fantasia..., p. 55).

151 Por exemplo, em ocorrências como esta: «(...) baseados num manual célebre do Dr. Roque Laia, daqueles "em que está lá tudo" (Fantasia..., p. 28). 
de uma personagem originou um registo, pareceu-me mais funcional, na última, considerar cada narração como um todo o que, em consequência, deu origem a um único registo de ocorrência. O mesmo aconteceu com o longo discurso de Nelson (73-5) e com o excerto de um episódio telenovelístico (137-9). Considerei essencial abrir uma exceção a este procedimento sempre que o conteúdo discursivo assumiu relevância para o postulado da verborreia lusitana. A título ilustrativo, refira-se a aventura que Emanuel conta a Angelina ${ }^{152}$ e onde, a dado momento, ele relata as últimas palavras do comandante da escuna a bordo da qual se encontrava, pois elas retomam um leitmotiv do romance que surge acoplado à isotopia do ruído e que será também objeto de estudo ${ }^{153}$.

Quando, numa mesma fala, ocorreu uma mudança de tipo de RD, foram feitos registos separados. Algumas das palavras das personagens resultam de falas conjuntas e assim foram registadas (e.g., nas páginas 218-9, as personagens falam em coro, primeiro o casal Lencastre e Maria das Dores e depois esta última e Maria José). Sempre que não foi possível identificar inequivocamente quem fala (e.g., na página 131, quando há uma referência aos ciganos, não se pode apurar quem reage, se é Lencastre ou a mulher) ou as personagens falam em coro foi feito um registo separado ("Lencastre ou Maria José?» ou «Os dois casais»). Logo, esses enunciados não integram a contagem de ocorrências individuais de RD. No caso em que parece ter existido uma falha na revisão tipográfica, comprometendo a lógica do diálogo - quando Bernardes conta uma história da sua juventude ao vizinho Lencastre (171) ${ }^{154}-$, considerei ser o enunciador o primeiro coronel.

Relativamente ao tipo de RD, considerei as formas definidas em 1.2.2. - DD, DI, DIL - e em 1.2.3. - DDL -, sendo convocadas, na análise dos dados e sempre que oportuno, observações relativas a

152 Cf. supra nota 54.

153 Cf. Fantasia..., p. 119: “Por mais que me enjeite a sorte, é melhor não disparar, um marujo bruto e forte, com o meu altivo porte, há-de dar o corpo ao mar" .

154 Cf. Fantasia..., p. 171: A fala «- Bem, deixa-me lá então contar... Já sabes, não...?» deveria ser atribuída a Bernardes, pela sequência do diálogo, mas pertence a Lencastre se se respeitar as marcas tipográficas de início de discurso (neste caso, o travessão). 
cada um desses modos de relatar palavras expendidas na primeira parte deste trabalho. Os enunciados que não respeitam as regras canónicas do RD foram agrupados sob a designação de Modo híbrido, tendo sido ainda considerada a categoria Reprodução de palavras no discurso do narrador, onde incluí os excertos que configuram as situações de polifonia discursiva acima definidas (ilbotas textuais e transcrições completas).

Relativamente aos verbos introdutores de $\mathrm{RD}^{155}$, entendi ser mais produtivo restringir o registo e a posterior análise às duas categorias semânticas principais: verbos dicendi e verbos sentiendi. Quando o narrador lança mão de outro tipo de verbos, fiz o registo "Sem verbo introdutor». Mais uma vez, considerei necessário abrir uma exceção: a da utilização metafórica do verbo "Rosnar», pela sua carga expressiva e relevância na caracterização das personagens. Foram reportados os verbos que integram expressões cristalizadas da língua (registadas como "Combinatórias fixas", e.g., "fazer conversa») e os que atestam a originalidade de MC (e.g., "emitir falas»), em expressões classificadas como "Combinatórias livres».

Todos estes dados recolhidos no romance perfizeram 832 entradas, lançadas na referida grelha elaborada para esse efeito. Em seguida, os dados foram tratados informaticamente e deram origem a sete relatórios - (1) Relatório Geral (sem citações); (2) Relatório Geral (com citações); (3) Infinitivos (por discurso); (4) Infinitivos (por personagem); (5) Personagem (por discurso); (6) Tipo de discurso (por personagem) e (7) Tipos de discurso -, que me permitiram posteriormente elaborar as tabelas que se encontram nos Anexos 4 a 7 . Os dados relativos a cada um dos aspetos analisados foram aí inseridos por ordem decrescente de ocorrência no romance, tendo sido apenas quantificados, nas tabelas 4 a 9 do Anexo 4, os que são quantitativamente mais relevantes. Por isso, nem todas as vozes selecionadas para registo vão ser objeto de análise.

155 Cf. supra 1.1. 
Pese embora alguma falha na exaustividade ou escolhas menos pertinentes no processo de recolha, organização e interpretação dos dados - até, por exemplo, na classificação de algumas ocorrências ${ }^{156}$-, elas não comprometem as ilações que tirei do papel crucial do RD para a representação identitária, em Fantasia..., uma vez que são sustentadas pelos dados empíricos que passo a apresentar e comentar.

\subsection{Ocorrências e funcionalidades do RD no romance}

\section{Tipos de relato de discurso ${ }^{157}$}

O DD tem uma presença avassaladora em Fantasia... (676 ocorrências, ou seja, $81,3 \%$ de todo o RD). Esta constatação não é inaudita, antes sublinha a coerência do narrador - «Eu, porém, mesmo quando há abuso, não guilhotino a palavra" (88) -, que recorre a este modo de RD para firmar a sua opinião sobre um país que nunca se cala. É um narrador que decide apagar-se diante da força elocutória das suas personagens, a quem atribui o papel principal na encenação cómico-trágica da realidade nacional. Graças ao RD, o narrador materializa o grande tema que o (pre)ocupa - a sonoridade estéril dos seus concidadãos ficcionais -, permitindo que, pela tirania da palavra, as personagens procedam quer à auto quer à heterocaracterização e desenhem, dessa forma, um espaço social português.

Para além do predomínio de falas em DD, esse mecanismo citacional recobre um número elevado de figuras ficcionais: no romance, ecoam 29 vozes diferentes em $\mathrm{DD}^{158}$.

156 Cf. supra 1.2.2.

157 Cf. Anexo 4, Tabela 1.

158 Dados obtidos depois da seleção de entre as mais de quarenta personagens inicialmente recenseadas. Cf. Anexo 4, Tabela 2. 


\section{Vozes que predominam ${ }^{159}$}

De entre as personagens individualizadas em Fantasia..., sobressaem as vozes de Emanuel (14,7\%) e do coronel Bernardes (14,2\%), logo seguidas das de Maria das Dores $(11,8 \%)$ e do coronel Lencastre $(11,5 \%)$.

O jovem Emanuel, que acumula o dom de localizar lençóis freáticos com o de jogar xadrez, é um pólo aglutinador do romance, uma âncora e um déclencheur de quase todas as peripécias narrativas ${ }^{160}$. Personagem peculiar, um pouco fora do seu tempo, aparenta ser um digno sucessor do tio que usa casacos de tweed (82), embora o sobrinho goze de um poder de sedução que o homem do "chapéu tirolês com uma peninha" (185) não parece poder igualar. Percorre o país na sua cúmplice Renault Quatro $^{161}$, sob o olhar benigno dos deuses. Para além das conversas que mantém com as personagens que se cruzam no seu caminho, é dado a efabulações, graças às quais acede aos mundos imaginários que são o seu verdadeiro elemento.

Por seu lado, Bernardes compõe com Lencastre (a quarta voz quantitativamente mais expressiva) um dueto nuclear que se anuncia logo no título. As duas personagens que verberam "deambulações, opiniões, descrições, filosofias, desarrumação..." (15) quando falam sobre livros são, ironicamente, duas das vozes que não se calam em Fantasia..., em grande medida por causa das suas histórias que evocam o passado - os tempos de juventude e a carreira militar na África portuguesa, referência inelidível ao nosso passado colonial.

159 Cf. Anexo 4, Tabela 3. As percentagens apresentadas são relativas à totalidade dos registos de $\mathrm{RD}$ do romance.

160 Cf. supra 1.2.1. e Anexo 1.

161 O mítico modelo da Renault, pela habilidade de que dá provas e pela cumplicidade protetora que o liga ao dono, assemelha-se ao carocha Herbie, protagonista de quatro rodas de filmes saídos dos estúdios da Disney (anos 70, século XX). As referências cinematográficas, a que já aludi (cf. supra nota 140), disseminam-se, das óbvias (183, 187, 215) às sugeridas (e.g., o plano mirabolante de Januário para produzir energia à custa de "quinhentos eslavos a dar ao pedal, numas bicicletas adaptadas», relatado por Lencastre na p. 189, parece dialogar com Les Triplettes de Belleville, o filme de animação de 2002, de Sylvain Chomet). Sobre as influências da $7^{a}$ arte em Fantasia..., veja-se, por exemplo, Piçarra (2008: 51-6). 
No início do romance, encontramos os dois coronéis à beira de uma piscina, que destoa na paisagem alentejana, a discutir literatura (15-6) e é aí, junto deles, que o fio narrativo é retomado quase no final (207), depois de uma dilatada e ruidosa analepse ${ }^{162}$.

Sobretudo pelo peculiar e excessivo discurso que mantém em quase todas as falas, Maria das Dores revela-se uma das presenças mais impressivas do romance, sendo igualmente uma das mais presentes, em termos numéricos.

\section{Discurso direto ${ }^{163}$}

Os dados recolhidos permitem tirar de imediato uma conclusão: as quatro vozes predominantes em Fantasia..., identificadas a partir dos registos da Tabela 3 do Anexo 4, surgem em DD, embora Emanuel passe para segunda voz mais presente neste modo de RD, pois é Bernardes o protagonista. Se este modo de relatar palavras ocupa $81,3 \%$ de todo o RD do romance, Emanuel, Bernardes, Maria das Dores e Lencastre, em conjunto, perfazem $44,6 \%$ das ocorrências. Estas quatro personagens também protagonizam o melodrama que encerra o romance: debaixo do teto que partilha com o marido, Maria das Dores seduz Emanuel. A traição é descoberta por Bernardes, mas a intervenção apaziguadora de Lencastre logrou evitar uma tragédia.

Nestas personagens, o recurso ao DD reveste-se de funcionalidades distintas. Em Maria das Dores - a personagem que «verbaliza muito» (30), acerca da qual é dito ser oriunda de uma família abastada e ter frequentado o "selecto Colégio de Odivelas" (29) -, o DD patenteia o contraste entre as suas origens e o registo vernáculo de língua que lhe é habitual. Tornam-se por isso significativas as inesperadas exceções à linguagem

162 Na rotina diária que se estabelece entre Bernardes e Lencastre, à beira da piscina, há lugar para reflexões mais ou menos filosóficas sobre assuntos da actualidade ou atinentes ao comportamento humano (146-7), para incursões metaliterárias (15-6), para a partilha de histórias de vida (134-6, 169-75).

163 Cf. Anexo 4, Tabela 4. 
desbragada que a caracteriza: quando encena um jogo de sedução com Emanuel (68) ou são reportados os seus pensamentos (70), consegue estancar o descontrolo verbal ${ }^{164}$, esforço testemunhado pelo leitor a partir do DD da personagem e não por indicação do narrador. É ainda em DD que Maria das Dores responde à pergunta do narrador que está a revelar as suas reiteradas infidelidades (184).

Em Lencastre, o DD constitui um recurso indispensável no processo de heterocaracterização de Januário: o narrador dá a palavra a uma das personagens, atribuindo-lhe a tarefa de traçar o perfil dessa figura que desperta no leitor uma antipatia visceral.

Igualmente significativa é a presença do narrador em DD $(7,2 \%)$ e, de entre as sessenta ocorrências recenseadas, encontram-se três interpelações ao leitor (60-1, 216 e 222), que fazem desmoronar de forma paródica a seguinte declaração de intenções proclamada na página 61: "Mas eu não sou um escritor manipulador» ${ }^{165}$. O narrador recorre ainda ao DD nas seguintes situações: como resposta à invetiva do tio de Emanuel (87), tendo o cuidado de se identificar como origo enunciativa ${ }^{166}$; quando lhe responde (também nessa página); quando apostrofa os «senhores prelados", comentando a conversa dos coronéis, a propósito da destruição da estação de serviço pelos claquistas (148); nas entrevistas para as quais convoca as duas principais figuras femininas - Maria José (175-8) e Maria das Dores (182-7) ${ }^{167}$. Observe-se que, sinalizando a rutura ontológica com o estatuto até ali assumido com estas duas personagens, o discurso do narrador não é precedido de travessão ${ }^{168}$. Também nas duas invocações à musa, no início (20) e no final (227), o DD é marcado apenas pelos dois pontos e parágrafo (no primeiro momento) e pelo parágrafo (no

164 O narrador informa que, quando pensa, Maria das Dores é "comedida, a falar é que desbocava" (70).

165 Besse classifica esta estratégia narrativa como "jogo irónico de auto-denegação" (2004: 13).

166 Cf. Fantasia..., p. 93: "Isto agora era eu a falar".

167 MC explica que as entrevistou para «acertar umas contas» e «evitar acusações de misoginia, que surgem sempre" (M. João Martins, 2003: 11).

168 Cf. supra 1.2.2. 
segundo). São exemplos da criatividade que o código literário autoriza e que devem ser explorados em contexto pedagógico.

A categoria "Outras vozes» representa 5\% das ocorrências em DD. A sua relevância será analisada a seguir.

Não posso deixar de fazer uma observação sobre o DD de Nelson: a sua importância decorre não da presença quantitativa (na verdade, as suas falas representam apenas $1,6 \%$ de todas as ocorrências neste modo de relatar palavras), mas da extensão e da expressividade do monólogo que verbaliza perante os pais (73-5). A funcionalidade particular deste DD será comentada mais à frente.

Uma última nota sobre os registos em DD: além das situações excecionais já identificadas, é recorrente a reprodução de palavras em DD sem a utilização de travessão - o narrador pode ou não fazer parágrafo, recorre às aspas para assinalar o locutor (mas inicia o RD com letra minúscula, como nas páginas 12 e 209) e apresenta uma sequência dialogal com os enunciados em DD apenas entre aspas (49 e 118). Trata-se de subversões à utilização dos marcadores gráficos habituais do DD, que devem ser estudadas em sala de aula ${ }^{169}$.

\section{Discurso indireto livre ${ }^{170}$}

Em termos de presença quantitativa em Fantasia..., segue-se o DIL. Sendo numericamente pouco significativo $(6,5 \%)$, traduz mais uma vez a coerência da estratégia narrativa, uma vez que este tipo de reprodução de palavras, pelo efeito mimético que confere ao texto ficcional, contribui para amplificar a voz das personagens e para revelar os seus traços de personalidade. Neste romance, as sequências em DIL são muito curtas,

169 A este respeito, Rosier declara que no DD pode existir sobremarcação. É a ausência de sinais tipográficos que pode levantar obstáculos (1999: 133). Estas estratégias discursivas, que se verificam em escala reduzida no romance em apreço, constituem um desafio para o professor de português (de LM ou LE).

170 Cf. Anexo 4, Tabela 5. 
não excedendo geralmente a frase ${ }^{171}$. Analisando os dados recolhidos, para além de, mais uma vez, se constatar o predomínio do discurso do jovem mestre de xadrez, verifica-se a presença de DIL na reprodução de palavras de Bernardes, de Januário e das «Outras vozes» que tecem a trama narrativa ${ }^{172}$.

\section{Reprodução de palavras no discurso do narrador ${ }^{173}$}

Em terceiro lugar em número de ocorrências de reprodução de palavras, surgem as palavras de outrem no discurso do narrador (4,8\%). Bernardes encabeça a lista de personagens (oito ocorrências); seguem-se, com seis ocorrências, "Outras vozes» e depois Januário e os Jornalistas, cada um com três situações recenseadas. Graças a esta forma de RD, o narrador consegue multiplicar a presença dessas vozes no romance e, simultaneamente, pela natureza das citações, marcar o seu distanciamento relativamente a elas (e.g., 60, 104 e 220)174.

\section{Discurso indireto ${ }^{175}$}

O DI tem um peso inferior ao do DIL $(3,4 \%)$ e representa no romance as vozes de Emanuel, Bernardes e, com número idêntico de ocorrências, Lencastre, Maria José e "Outras vozes». Em último lugar, surgem Januário e Maria das Dores.

${ }^{171}$ A título de exemplo, transcrevo um excerto da p. 52: «Sim, sim, a Sandra tinha passado por ali, mas, pelos vistos, não quisera perder o espectáculo da Soraia Marina».

172 Como já referi, depois desta apresentação essencialmente quantitativa, será feita a interpretação das ocorrências de RD que considero indispensáveis como ilustração da tese defendida no romance.

173 Cf. Anexo 4, Tabela 6.

174 Cf. Fantasia...: "(...) pelo vulgo chamada "catrapila" (60), "(...) ou das chamadas "grandes superfícies" (104) e "(...) para uma conversa sobre "como as pessoas são" (220).

175 Cf. Anexo 4, Tabela 7. 
A escassez de reprodução de palavras em DI é mais um elemento que parece confirmar que, em Fantasia..., o narrador se aproxima do dramaturgo: abdicando de estratégias de mediação discursiva, oferece a boca de cena às suas personagens, essencialmente em DD.

\section{Modo híbrido ${ }^{176}$}

Globalmente, em Fantasia..., o narrador utiliza as formas prototípicas de RD. Classifiquei $2,3 \%$ das falas como modo híbrido, uma vez que, de alguma maneira, representam uma subversão das regras canónicas de RD que expus em 1.2.2. Analisados os dezanove excertos que considerei periféricos ${ }^{177}$, confirma-se, em primeiro lugar e mais uma vez, a atribuição deste tipo de reprodução de discurso no discurso a duas das personagens fulcrais do romance - Emanuel e Maria das Dores (três são relativos a Emanuel, outros três a "Outras vozes» e dois proferidos quer por Maria das Dores quer por Januário); em segundo, que todos os excertos que derrogam as regras de RD incluem traços com grande valor mimético: nove ocorrências resultaram da hibridação de traços de DD com características de DI $(56,66$, $69,112-3,116,122,130,190$ e 209), quatro, de hibridação de DDL com DIL (98, 122, 162 e 210-1) e dois de esbatimento de fronteiras entre DD e DIL (50 e 57). No que diz respeito ao incumprimento da ortodoxia gramatical, constata-se que a subversão mais significativa tem a ver com a elisão da conjunção subordinativa, o desrespeito pelas regras de concordância dos tempos verbais e a inclusão de traços oralizantes em falas onde não deviam marcar presença. Assim, confirma-se de novo que, no romance, é primordial para o narrador transmitir de forma verosímil as vozes das suas personagens, ainda que decida fazê-lo criando casos-fronteira de RD.

\footnotetext{
176 Cf. Anexo 4, Tabela 8.

177 Cf. Anexo 5. Na Tabela 2, estão registadas e comentadas todas as ocorrências.
} 


\section{Discurso direto livre ${ }^{178}$}

É também Emanuel que, com seis ocorrências (0,7\%), concentra em si a maior representatividade desta forma de $\mathrm{RD}$, que ocupa $1,8 \%$ de todas as falas reproduzidas no romance. As outras personagens a quem o narrador atribui esta forma de relatar palavras são, em geral, as já referidas - Bernardes, Januário, Maria José, Lencastre e “Outras vozes» -, à exceção de Sandra e Nelson.

\section{Verbos introdutores de RD ${ }^{179}$}

Como complemento indispensável da análise quantitativa e da distribuição dos vários modos de reproduzir palavras pelas personagens do romance, encontra-se o levantamento e classificação dos verbos introdutores de $\mathrm{RD}^{180}$. É uma tarefa indispensável quer no processo hermenêutico quer numa abordagem pedagógica, porquanto é um dos domínios em que a maior parte dos alunos revela uma considerável pobreza lexical (Duarte, 2001: 126).

Embora não se trate de matéria relativa a mecanismos de citação, parece-me incontornável, em contexto de sala de aula, começar o estudo de Fantasia... pelo discurso do narrador nas páginas iniciais do romance, quando procede à apresentação do seu ponto de vista sobre a tagarelice nacional e apresenta as primeiras personagens. É também a expressão de uma voz, que funciona em contraponto crítico com as outras que enxameiam a trama narrativa. Enuncio alguns exemplos reveladores da sua exuberância e expressividade lexicais, que marcam um nítido contraste com a penúria vocabular do discurso das figuras ficcionais e remetem de imediato para o tema que vai ser tratado - a

178 Cf. Anexo 4, Tabela 9.

179 Cf. Anexo 6.

${ }^{180}$ A análise da transição entre vários modos de RD e da relevância expressiva e crítica dos discursos atributivos será feita aquando do estudo das personagens que melhor ilustram a tese exposta no início do romance. 
vozearia inconsequente, que faria Portugal soçobrar sob o seu peso caso as palavras não fossem levadas pelo vento181: "Assolar» (11), "Ferver» (11), "Falar» - primeiro numa tripla e depois numa dupla enumeração ("Fala-se, fala-se, fala-se", "O país fala, fala», p. 11) -, "Desunhar-se a falar» (11), "Zunzunar do paleio» (11), "Cantar» (12), "Soltar as línguas» (12), "Dar à taramela» (12), "Falajar, falajar, falajar." (12), "Nutrir o paleio" (12), "Falar com os botões" (14), "Palrar» (15), "Tagarelar» (15), "Taramelar» (15), «Irromper» (17), «Varrer» (17), «Atordoar» (17), «Estralejar» (17), «Soltar-se» (20) e "Ricochetear» (20).

Encontra-se ainda uma eloquente variedade de nomes comuns e uma criteriosa seleção de adjetivos de valor hiperbólico, muitas vezes integrando expressões de valor gradativo ascendente, como, por exemplo, "pulsão coloquial»(11), «estado frenético de tagarelice» (11), «multiplicação ansiosa de duos, trios, ensembles, coros» (11), «rumorejos, conversas, vozeios, brados" (11), "falatório" (11), "em todos os tons e decibéis» (11), "tagarelice» (11), "paleio" (11), "afã elocutório" (12), "o país tagarela» (13), "cavaqueira» (16), "clamor» (17), «rugido» (17), «ecos multiplicados» (17), "urros isolados e guinchos agudos» (17), «algazarra» (17 e 20), "falas» (17), "clamor grosso" (17) e "clamor» (20), "repiques de som» (18) e "garganteio selvagem» (20).

As linhas temáticas do ruído, do excesso e da vacuidade ${ }^{182}$ são, assim, definidas nas vinte primeiras páginas de Fantasia..., pelo que creio dever ser a primeira aproximação ao romance a constatação da forma como o narrador chama a si as modulações da voz, numa espécie de antecâmara do espetáculo operático que vai encenar, construindo uma perspetiva narrativa a operacionalizar através da reprodução das palavras das personagens.

No romance, predomina o DD, como já referi, ocorrendo, na sua maioria, sem verbo introdutor (452 ocorrências). Nas duzentas e

181 Cf. Fantasia..., p. 13: «O país pereceria num sufoco, aflito de rouquidões, atafulhado de vocábulos, envenenado de sandices, se a Providência caridosa lhos não disseminasse por desatinadas paragens".

182 Cf. Fantasia..., p. 14: «Enfim, falar com os botões é nisto que redunda, pergunte-se a uma pastora chamada Mofina, uma leiteira chamada Pérrette e ao brâmane, chamado Svabhvakripana». 
vinte e quatro situações em que o narrador lança mão de um verbo introdutor - ainda que os de uso recorrente não sejam particularmente expressivos ou variados ${ }^{183}$-, plasma-se no texto, uma vez mais, a isotopia da sonoridade. Os mais ruidosos são "Bradar", "Ecoar", "Esganiçar-se», "Exclamar», "Flautear», "Gritar», "Protestar», "Ralhar», "Resmonear», "Resmungar», "Trautear» e "Vozeirar», registando-se, igualmente, expressões que classifiquei como "Combinatórias livres", das quais saliento "Emitir falas", "Ouvir uma voz" e "Soltar-se a voz". O DD surge também introduzido por verbos sentiendi (dezassete registos). A diferença quantitativa entre as duas categorias semânticas de verbos (cinquenta e sete verbos dicendi) confirma que, no romance, predomina a voz exterior, que o narrador procura reproduzir de forma verosímil, imitando o discurso oral das personagens, em relação ao qual se distancia criticamente.

Dos verbos/combinatórias que introduzem outras formas de $\mathrm{RD}^{184}$, considero mais expressivos "Vir com uma conversa" (no DIL), "Soltar um garganteio selvagem» (na reprodução de palavras no discurso do narrador), "Perorar» (no modo híbrido) e "Entoar loas» (no DDL).

No romance, como vai ser referido oportunamente, é fulcral o modo como a voz é qualificada, no discurso atributivo (e.g., relativamente às personagens Januário e Nelson).

Uma derradeira observação sobre a produtividade do estudo, em aula de PLE, de outros verbos que integram a tessitura narrativa e que não foram incluídos nos registos. Embora tenha optado pela solução mais económica no que diz respeito à classificação dos verbos introdutores de $\mathrm{RD}$, penso que seria muito fecundo, por exemplo, uma reflexão sobre o uso metafórico de "Rosnar» (59, 120 e 217), a presença de verbos mais incomuns, como "Repristinar» (88) ou recorrentes no idioleto do escritor, como "Casquinar»(36)185. Outra hipótese de trabalho, com o propósito de

183 Os três verbos dicendi mais utilizados, no DD, são "Dizer» (46 vezes), "Responder» (17 vezes) e "Perguntar" (16 vezes). O verbo sentiendi usado mais frequentemente é "Pensar» (13 vezes) e depois, com duas ocorrências cada, "Admirar-se», "Compreender", "Considerar» e "Surpreender-se».

184 Cf. Anexo 6, Tabelas 2 a 6.

185 Também surge no romance o nome "casquinada" (217). 
ampliar o leque de verbos suscetíveis de serem utilizados nos mecanismos de reprodução de palavras, seria encorajar os alunos a manipular a língua e a ousar deixar a zona de conforto oferecida pelo comuns "Dizer» e "Responder» ${ }^{186}$. É igualmente essencial, em contexto pedagógico, haver lugar para a constatação da existência de verbos incompatíveis com mecanismos de $\mathrm{RD}^{187}$.

Em síntese, o recenseamento dos excertos em que surge cada um dos modos de reprodução de palavras considerados faz ressaltar a presença massiva de vozes em DD, no romance, o que nos permite ajuizar da relevância que o narrador confere à apreensão não mediada dos discursos das suas personagens. Sentindo-se importunado pelo ruído avassalador que submerge o país, demonstra, pelo recurso numericamente expressivo ao RD - e sobretudo ao DD - que o vozear que tomou de assalto Portugal é sinal de vacuidade, de falta de espessura, de ignorância, de desconcerto. Essa verborreia alimenta projetos inexequíveis e opiniões inconsequentes e/ou concretiza-se em subprodutos, apresentados ostensivamente como grandes realizações e/ou desfrutados com deleite por gente inculta e incivilizada, que não percebe que o é. Assim, assumindo-se Fantasia... como um texto sobre a verbosidade, oca e limitadora, é a verborreia das personagens que explode na obra.

A obsessão da palavra oralizada e a escassez de conhecimento da palavra escrita, neste Portugal do novo milénio, agravam o "gram trabalho" que "he vyver»188 (9) e conduzem à interrogação desencantada do narrador, no final da obra: «Há emenda para este país?» (227).

Analisemos agora a capacidade representativa do RD na reconfiguração de imagens identitárias.

186 A título de exemplo, cf. infra Anexo 13, Ficha de trabalho 2, exercício B.

187 Cf. supra 1.3., o exemplo de DI encontrado em Itinerário Gramatical - «Ela tagarelou constantemente que não queria comer» (p. 63) -, que podia constituir um ponto de partida, em aula de PLE.

188 Cf. epígrafe de Fantasia... (9). 


\subsection{Notas dissonantes}

\section{Maria das Dores}

Como já foi referido, Maria das Dores é a terceira voz mais presente em Fantasia... e uma das que lidera as ocorrências em DD. Além disso, é a figura mais interessante do romance, quer do ponto de vista da construção da personagem quer especificamente do discurso ${ }^{189}$.

Herdeira abastada - personificação do velho Portugal latifundiário que sobreviveu aos ventos revolucionários e se adaptou às novas regras democráticas, mantendo intocadas as prerrogativas de outrora ${ }^{190}-$, tudo nela é excesso e desconcerto: recebeu uma educação esmerada, mas mantém-se refratária às normas do decoro social e "verbaliza muito" (30); interessa-se pelo estudo, por arte e literatura ${ }^{191}$, porém permitiu a instalação do "monumento» ${ }^{192}$, manifestação de novo-riquismo pseudo-intelectual193; é abastada e voluntariosa, contudo, surge quase sempre dominada pelo azedume, protagonizando uma luta surda com o marido (111), o que no fundo apenas sublinha os sentimentos que o seu nome deixa adivinhar e que a própria personagem

189 Cf. as palavras de MC sobre esta sua criação ficcional: «A Maria das Dores partilha das características da Magda [personagem de O Livro Grande de Tebas Navio e Mariana] na medida em que é senhora de uma completa desinibição. A Maria José, pelo contrário, é uma mulher pacata que procura que tudo esteja harmonioso. Temos, pois, uma oposição entre o espírito apolíneo e o espírito dionisíaco. Uma, cheia de energia, vive no meio de trapalhadas várias; a outra é contemplativa” (M. João Martins, 2003: 11).

190 Cf. Fantasia..., p. 27: «(...) Uma latifundiária de alto lá com ela, ainda por cima absentista e grande tiradora de cortiça". E ainda: "O pai tinha dois "de" e um "e" no apelido e possuía úberes terras de sobro, a perder de vista e tresmalhadas" (30). Sobre os privilégios de que usufrui o casal Bernardes, escreveu M. A. Seixo: «(...) Monte evocador, por antítese, das eras da Reforma Agrária” (2004: 112).

191 Formou-se em História de Arte (29), ocupa-se "com os seus jornais, as suas revistas, as suas fichas, os seus álbuns, o seu computador» e prepara uma tese de mestrado (32).

192 Cf. Fantasia..., p. 10: "Maria José chamava monumento a uma justaposição de livros de mármore, todos do escritor José Saramago, que se empilhavam, sabiamente desalinhados, quase à altura de um homem, com exagero na grossura de uns tomos e avareza na lombada de outros".

193 A argúcia demolidora de MC é confirmada por dados estatísticos: numa sondagem realizada em Maio de $2001,54 \%$ dos inquiridos revelaram não ter nenhum escritor português da sua preferência; dos $45 \%$ que indicaram um nome, 10,9\% referiram Saramago (Sá \& Reto, 2002: 179). Os Bernardes não conheciam decerto nem os livros nem as posições ideológicas do escritor. 
confessa, no extenso diálogo que tem com o narrador ${ }^{194}$. As suas imagens de marca são a brusquidão de gestos e a agressividade verbal, o registo popular e a licenciosidade da linguagem - esta última outrora fator de sedução (30), convertida mais tarde em embaraço para o marido (29), que anseia por vê-la "exprimir-se como gente crescida»(111) e, para alguns, motivo de desagrado no convívio social (177). Ocasionalmente, surpreendemos nela alguns lampejos de humanidade e de ternura (29).

O comportamento da personagem é qualificado pelo discurso do narrador: revela uma passividade cruel em relação ao marido ("respondeu fleumaticamente», p. 64; “imperturbável», p. 132), por vezes uma gentileza interesseira ("muito doméstica», p. 139; "estava a dar-lhe para perguntas", p. 142), uma raiva mal contida ("com alguma brusquidão", p. 206; "atirou a resposta", p. 213), que pode transformar-se num tom claramente ameaçador, como acontece quando se apercebe de que Maria José também se sente atraída por Emanuel ("rosnou», p. 217). Por isso, chama a atenção a mudança de atitude da personagem sempre que se encontra junto do jovem xadrezista ("numa simpatia sorridente para com Emanuel», p. 218; "fartou-se de fazer perguntas amáveis», p. 221; despediu-se de Emanuel "com um discreto "boa noite" ", p. 221). Em contrapartida, o discurso grosseiro e de registo eminentemente popular da personagem, herança das suas origens rurais que nenhum colégio seleto ou tese de mestrado conseguiram(ão) burilar, é revelado em toda a sua força impressiva e expressiva195. Assim, a caracterização da personagem que apenas é moderada quando pensa (70) e quando se refere, com ironia trágica, às justificações psicológicas expendidas pelas revistas femininas sobre a sua «brusquidão de maneiras» (183) faz-se quase exclusivamente pelo DD. Este modo de relato de discurso é também escolhido pelo narrador

194 Cf. Fantasia..., p. 186: "- Sou um bocado pró infeliz, sabe?» (186).

195 Cf. Anexo 8. O levantamento foi feito com uma dupla finalidade: por um lado, averiguar a expressividade das falas de Maria das Dores; por outro, tentar perceber o grau de dificuldade de compreensão para alunos de PLE. A questão do vernáculo na sala de aula dirime-se com um argumento que me parece irrefutável: o público-alvo virtual é constituído por jovens adultos em imersão, ou seja, expostos a níveis de língua menos vigiados. Para além de os ajudar a discernir qual o registo adequado para cada situação (vertente da competência pragmática essencial numa LE), o discurso de Maria das Dores possibilitaria, e.g., o estudo de expressões feitas ou do campo semântico do insulto. 
para revelar um lado oculto do comportamento de Maria das Dores: se, no início do romance, o narrador apenas lança um indício ${ }^{196}$ e sugere depois alguma leviandade da personagem ${ }^{197}$, a revelação do adultério é concretizada apenas em DD, quando o narrador interpela Maria das Dores ${ }^{198}$, que tenta justificar-se com o provérbio «- A cabra puxa sempre para o monte» (184): para além da ironia do recurso a um vocábulo que tem, em português, um sentido figurado pejorativo (é a mulher infiel e sem escrúpulos), "cabra» evoca a ascendência rural e burgessa da personagem. A mesma imagem, acrescida de novas ambiguidades, é verbalizada, pelo narrador, quase no final do romance, a propósito do jogo de xadrez que Emanuel deverá disputar de olhos vendados ${ }^{199}$. A mulher de Bernardes utiliza ainda dois outros provérbios ${ }^{200}$, que sublinham as suas duas principais características - ruralidade e libertinagem de palavras e costumes - e que poderiam ser explorados na aula de PLE, por exemplo em confronto com máximas populares dos países de origem dos alunos com idêntico conteúdo proposicional e valor pragmático.

As falas de Maria das Dores noutros modos de RD não são significativas. Registo duas exceções de reprodução de palavras em modo híbrido ${ }^{201}$ : uma em que se mesclam características do DD com traços do $\mathrm{DI}^{202}$ e que surge integrada no discurso do narrador, sem nenhum tipo de marcação tipográfica - esta escolha do narrador introduz ritmo e articula-se

196 Cf. Fantasia..., pp. 30-1: "Já o matrimónio ia adiantado, o coronel começou a tratar Dores por "a baronesa" [...] após um incidente que mais tarde se mencionará e que o coronel Bernardes apreciou muito de esguelha".

197 Maria das Dores tenta moderar a linguagem, na presença de Emanuel, substituindo o mau humor habitual por um sorriso "carregado de afecto" (67-8).

198 Cf. Fantasia..., p. 184: «Porque é que você engana o seu marido?» e «O coronel só soube do tenente, não foi?».

199 Cf. Fantasia..., p. 221: «Maria das Dores, muito cabra-cega, foi a correr buscar a pala de dormir". A expressão do narrador sublinha a leviandade da personagem, que irrefletidamente tenta o destino na sua própria casa. Recorde-se que, momentos antes, Lencastre adverte Bernardes de que tem "uma melga na testa", enunciado apresentado em DD que é um indício da traição que vai ocorrer debaixo do teto do próprio marido enganado (218).

200 Cf. Fantasia..., pp. 184 - «Tudo como dantes, quartel-general em Abrantes» - e 218 - "Quem não presta para comer...".

201 Cf. Anexo 5, Tabela 2.

202 Cf. Fantasia..., p. 69: «Se não ficava para jantar?, perguntou». 
naturalmente com a narração, que prossegue de imediato ${ }^{203}$; e uma outra em que se verifica a elisão do verbo dicendi ${ }^{204}$, o que também permite manter a cadência narrativa - depois do jantar, os dois casais bombardeavam Emanuel com perguntas e comentários ("Era uma galhofa», p. 219).

A mulher de Bernardes é ainda caracterizada por Maria José, quando esta se encontra com o narrador. Em DD, Maria José reitera os traços de carácter de Maria das Dores já assinalados (linguagem desbragada, autoritarismo, estatuto económico, vaidade) ${ }^{205}$.

Os verbos introdutores de $\mathrm{RD}$ mais utilizados com esta personagem são "Dizer» e "Perguntar», sendo de salientar uma ocorrência de "Rosnar» (217), sinal do confronto surdo com Maria José (por causa de Emanuel e contribuindo para a caracterização da personagem).

Sintetizando, Maria das Dores dá-se a conhecer sobretudo através de falas em DD, suas e do narrador, sendo a peculiaridade do discurso o seu traço mais individualizador. A infidelidade é revelada igualmente em DD, mas pelo narrador, porquanto os códigos morais e sociais do ambiente em que se movimenta não autorizariam a personagem a fazer uma revelação desse teor. A singularidade e variedade do seu discurso oferecem amplas hipóteses de exploração pedagógica.

\section{Januário}

Personagem de duas caras ${ }^{206}$, típico chico-esperto português ${ }^{207}$, a sua voz recobre todos os modos de RD recenseados 208 - DD (26), DIL (5),

203 Aliás, logo após a pergunta da personagem, o narrador conta: «Mas, de súbito, Emanuel desatou a tremer [...]»(69).

204 Cf. Fantasia..., p. 219: "O pai tinha-lhe ensinado, em miúda".

205 Cf. Fantasia..., p. 177: “(...) ela é mais nova, mais desinibida. Usa uma linguagem que não liga muito com o meu estilo. É mandona, menina rica, está toda envaidecida por estar a fazer a tese...».

206 Como Jano. Cf. a polidez afetada da personagem em público (52-3) com a grosseria e a violência, física e verbal, que revela em privado (57-60).

207 Cf. supra 2.4.

208 Entre parênteses, está o número de ocorrências de cada modo de RD. 
reprodução de palavras no discurso do narrador (3), DI e modo híbrido (2 cada), DDL (1) -, o que comprova a relevância que o narrador lhe atribui enquanto figurante da opereta rumorosa e desencantada que compõe no romance.

A voz de Januário é significativamente qualificada desde que ele entra em cena. Num crescendo que expõe a boçalidade e a irascibilidade da personagem, depois da queda da máscara que afivela socialmente, o leitor escuta o seguinte: "uma voz tranquila, levemente enfadada» (52) - o advérbio sublinha a presunção; «em voz alta para que todos ouvissem» (52) e "com voz grave e intensa" (53) - a oração final e a dupla adjetivação atestam a preocupação com a imagem e a encenação que leva a cabo; «um enérgico “Tá dito!” que não admitia mais conversas» (55) - o adjetivo indicia o carácter autoritário; "a voz já se lhe entaramelava»(58), "Aquela voz, à medida que enferrujava, tornava-se cada vez mais autoritária» (59) e «E que voz, roufenha, hesitante, formada debaixo da língua!» (60) - ilustram o crescendo de embriaguez e violência; "o vozeirão do Januário» (60) - o grau aumentativo traduz a agressividade da personagem. É o culminar de um processo (de "Voz tranquila» a "vozeirão») que expõe a verdadeira face de Januário, estalado o frágil verniz que ostenta em contextos sociais. Também no discurso atributivo se expressa essa gradação ascendente: "(...) agarrou Emanuel por um braço, gentilmente» (52), "com um rijo aperto de mão" (55), "muito seguro de si" (59), "com um ar torvo" (59), "com a mão em cutelo" (60).

O pretensiosismo e a vulgaridade da personagem são sublinhados em DD, pelo tom enfatuado das palavras que profere, onde ressaltam as redundâncias ${ }^{209}$, as frases exclamativas supostamente de grande efeito retórico ${ }^{210}$, a típica fórmula de tratamento entre empresários de sucesso de baixo estatuto social, a sugerir grande cumplicidade ${ }^{211}$, os diminutivos

209 Cf. Fantasia..., pp. 52: «- Meu caro professor, saiba que eu nutro, nutro e cultivo, a maior admiração por si e bem assim por todos os praticantes dessa nobre arte que é o xadrez que desenvolve o intelecto e o espírito», 53: «- Continue! Sobretudo, não desista!» e 55: "Foi decorada pela Xuxu Montevedro e Castro, a própria, em pessoa».

210 Cf. Fantasia..., p. 53: «- Continue! Sobretudo, não desista!».

211 Cf. Fantasia..., p. 55: «O meu amigo vem cear lá a casa». 
abundantes insinuando intimidade com o interlocutor ${ }^{212}$, a linguagem grosseira que se intensifica à medida que Januário fica sob o efeito do álcool $^{213}$. O mau gosto deste novo-rico bem-sucedido e sem escrúpulos 214 é mostrado logo na descrição da indumentária ${ }^{215}$, sendo o descomedimento - quer do espaço que habita ${ }^{216}$ quer do próprio carater ficcional217 - sublinhado pelo discurso do narrador.

São significativas as formas verbais introdutoras de RD que acompanham Januário, pois, mais uma vez, sublinham a sua prosápia e crescente agressividade: «confessou» (52), «aconselhou» (53), «explicou» (55 e 56), "declarou» (55), «segredou» (57), «mostrou» (58), «observou» (58), "tinha garantido" (58) e "rosnou», em sentido metafórico (59).

Numa nítida estratégia de distanciamento, o narrador recorre à citação, no seu discurso, de falas de Januário que revelam a sua iliteracia ${ }^{218}$ e completam a caracterização da personagem pela voz: primeiro, as próprias, sobretudo em DD, mas também em DI e em DIL ${ }^{219}$. O narrador subverte uma vez as regras canónicas do DD, numa estratégia que, combinando esse tipo de RD com DI, mantém a sugestão de proximidade com a voz da personagem que fala ${ }^{220}$.

Januário reaparece no romance pela voz de Lencastre. A heterocaracterização é feita pelo coronel em DD, quando relata ao vizinho Bernardes

212 Em DD, «joguinho» e «Sandroca», em DI, «cadeirinha» e, em DIL, «voltinha» (pp. 55-6).

213 Cf. Fantasia..., pp. 58-60.

214 Cf. Fantasia..., pp. 57: «- Não faz mal - respondeu o homem -, os bombeiros depois apagam» e 57-8: «Está aqui o passaporte dela, quer ver?».

215 Cf. Fantasia..., p. 52: «Era um homem baixo, a rondar os cinquenta anos, vestido de blaser preto, com botões redondos de lata dourada, calça amarelo-torrado, e camisa cor-de-rosa, duma marca anunciada na televisão".

216 Cf. a descrição da sala, na p. 56: "profusamente», «descomunal», «fazia lembrar o átrio de um hotel", "com muitos sofás [...], muitas cortinas malva, muitos embutidos dourados $[\ldots]$ enormes $[\ldots]$ profusas $[\ldots]$..

217 Para além da roupa (cf. supra nota 215), cf. pp. 52: os olhos «muito esbugalhados", 57: "atirava-se a uma pratada de gambas.» e 58: «ia no terceiro copázio de uísque».

218 Cf. Fantasia..., pp. 55 e 57: “O que o homem disse [...] “trázio!”, de acordo com os seus hábitos.» e "(ele dizia "orientava")".

219 As curtas sequências em DIL surgem sobretudo depois de DI (55, 56 e 58), mas também depois de DD (57) e de uma sequência de discurso narrativizado (58).

220 Cf. Fantasia..., p. 57: "Aquela, segredou, era a Natacha, uma russa que trabalhava num estabelecimento nocturno que explorava». 
uma ida a Lisboa: Januário "agora está bem na vida" (188) e "anda armado em cacique» (188). A enumeração dos cargos que acumula ${ }^{221}$ parodia o fura-vidas sem princípios, que se vangloria de ganhar dinheiro à margem da lei, explorando mulheres ${ }^{222}$, e que, como ponto culminante de um percurso de sucesso, acredita "que já tem condições para se meter a sério na política»(188). Lencastre recorre também ao DI223 e sobretudo ao DIL ${ }^{224}$. Esta opção que permite mimetizar o discurso do empresário desonesto e fanfarrão multiplica a sua voz no romance, não só confirmando todos os vícios que já tinham sido desenhados no desastrado serão com Emanuel - prosápia, prepotência, mau gosto, destempero no consumo de álcool - como alargando o rol de defeitos de que enferma a personagem (caciquismo). As escolhas linguísticas do coronel-narrador não são inócuas (e.g., verbos "Armar" e "Mamar»), porquanto denunciam a sua opinião sobre Januário ${ }^{225}$.

Em suma, a personagem é caracterizada pelo discurso do narrador (sobretudo, pela qualificação da voz), pelo DD (na interação com Emanuel) e em DI e DIL, pelos dois coronéis que o conheciam das campanhas militares africanas 226 .

A descrição disfórica de Januário contrasta surpreendentemente com o sucesso clamoroso da personagem. Estereótipo do chico-esperto que

221 Cf. Fantasia..., p. 188: «É presidente do clube de bola, vereador da Câmara, sócio honorário dos bombeiros, tem uma padaria, uma fábrica de louças, três oficinais de automóveis, quatro lojas de electrodomésticos, duas casas de alterne, um bar e um bordel clandestino e mais não sei quê».

222 Cf. Fantasia..., p. 188: «(...) bordel clandestino [...]. Pelo que me deu a entender, está total e absolutamente isento de impostos».

223 Cf. Fantasia..., p. 189: «Diz que tem uma casa com quatro elevadores e uma arca frigorífica sempre a abarrotar de marisco».

224 Cf. Fantasia..., p. 189: "Se pusesse quinhentos eslavos a dar ao pedal, numas bicicletas adaptadas, não conseguiria gerar energia suficiente para a vender com lucro à EDP?».

225 Cf. Fantasia..., p. 188: «Segundo percebi, anda armado em cacique duma vilória [...]. O gajo estava a fazer tempo, ofereceu-me uma cerveja, tratou de uns negócios pelo telemóvel e mamou dois uísques. Ficou muito desinibido".

${ }^{226}$ Em DD, Bernardes faz a caracterização física de Januário: «(...) um pitorra de olhos muito arregalados [...]» (188). Os dois coronéis comentam a desonestidade de Januário, antes de estourarem «de riso». Diz Bernardes: «- Andámos nós na tropa a formar estes homens, a dar-lhes educação, princípios, horizontes, para isto. Onde é que nós falhámos?» (190). 
não olha a meios para atingir fins ${ }^{227}$, acaba por ser o único verdadeiro empreendedor e vencedor do romance, o único cujo discurso «não dá em terra» e que parece não sentir a canseira de viver, proclamada por Anrique da Mota 228 .

Entre Maria das Dores, representante do velho Portugal reconvertido aos novos tempos, e Januário, o parasita que medra nos interstícios da lei e da civilidade, o "garganteio selvagem" (20) que atroa os ares e alastra a todo o país.

\section{Os claquistas}

Entidade coletiva que surge logo nas primeiras linhas de Fantasia..., numa citação incluída no discurso do narrador que descreve hiperbolicamente o ruído avassalador que ecoa em todo o retângulo nacional ${ }^{229}$, estes adeptos são a encarnação do Portugal alarve, acéfalo, que se compraz em atos gratuitos de violência e destruição ${ }^{230}$. Ressurgem no discurso do narrador (105-10) e finalmente num diálogo entre Bernardes e Lencastre, a propósito da notícia do jornal que dá conta das consequências da passagem da claque pela estação de serviço (146-7). Ainda que seja escassa a configuração desta personagem coletiva pelo $\mathrm{RD}$, não pode deixar de ser considerada, por duas ordens de razão: em primeiro lugar, porque representa metonimicamente todos aqueles que se metamorfosearam devido à obsessão futebolística, sendo uma das representações do Portugal contemporâneo ${ }^{231}$; em segundo, pela assombrosa focalização de Emanuel,

227 Cf. Gil (2009), referido em 2.4.

228 Cf. supra nota 188.

229 Cf. Fantasia..., p. 20: «(...) Solta-se um garganteio selvagem, "Olá, olá, olá, olá”, vem de regresso a algazarra do campo de futebol que já deu volta ao país, ricocheteou nas serras do Barroso e nos passa agora em cima, a querer submergir e apoucar".

230 Sobre estes hooligans, disse MC: «São um bando de quadrúpedes. Não são muito diferentes disso. E é a mentalidade dos "reality shows" das televisões. E de quem anda nas televisões e de quem manda nas televisões" (Coelho, 2003: 5-6).

231 Quando o romance foi publicado, Portugal preparava-se, com grande frémito, para acolher o Campeonato Europeu de Futebol de 2004. 
personagem aglutinadora no romance. Todo o episódio está configurado como se de uma representação dramática se tratasse, assumindo Emanuel, involuntariamente, o papel de espetador-testemunha da "grande orgia devastatória” (107)232. A torrente discursiva, da responsabilidade do narrador $^{233}$, convoca a audição e a visão e realça, em tom desmesurado, as isotopias do ruído, da bestialidade e da violência ${ }^{234}$. Através de recursos expressivos como a hipérbole (presente em todo o episódio), verbos onomatopaicos («tilintar», p. 107), aliterações («estalava em estrondeio», p. 106; «soou o silvo», p. 198), pleonasmos («enormes bocarras», p. 107), enumeração assindética ( aglomeraram-se, empurraram-se, ganiram, lá conseguiram entrar num rodilhão", p. 109) e de uma seleção lexical primorosa, o leitor confronta-se com a ruína que os claquistas semeiam e que contrasta com a placidez revelada pelo motorista (107 e 108), sinal chocante da naturalidade com que aqueles comportamentos animalescos são olhados por quem com eles convive.

A funcionalidade das falas em DD das personagens que estão em cena - o segurança e Angelina - é, em primeiro lugar, permitir contrapor a estranheza do olhar de Emanuel à indiferença cobarde quer do primeiro 235 quer da empregada da estação de serviço ${ }^{236}$; em seguida, permite perceber que, apesar de a invasão dos hooligans ser uma prática recorrente ${ }^{237}$, encontra sempre caminho livre, seja devido à passividade de quem lá trabalha, que recusa participar o incidente à polícia ${ }^{238}$, seja

232 Cf. Fantasia..., pp. 106: “(...) estavam agora, ele e a rapariga, acaçapados entre arbustos, numa elevação que escorria para as bombas de gasolina e donde podiam assistir, menos mal, ao que se ia passar» e 107: "Do sítio em que espreitava, ao reflexo das luzes, Emanuel conseguia distinguir, soltados por alguns dos indivíduos, gordos cordões de baba [...]».

233 Cf. Anexo 9, Tabela 1 (Transcrições do romance) e Tabela 2 (Classes de palavras).

234 Cf. Anexo 9, Tabela 1.

235 Cf. Fantasia..., p. 106: "Anunciou, com lealdade: "Eu ponho-me mas é na alheta" e cumpriu, escapulindo-se pela porta do fundo".

236 Cf. Fantasia..., p. 106: «- Esteja quieto, não se mexa! - A rapariga puxou-o com força. E segredou-lhe: - Pois, viam-no ir, e ficavam logo a saber que eu estou aqui. Olhe para aquilo!».

237 Cf. Fantasia ..., p. 107: «- Meu Deus, outra vez! - sussurrou a rapariga chegando-se mais a Emanuel. - E hoje perderam o jogo. Vai ser pior!».

238 Cf. Fantasia..., p. 110: «- O quê? Parece que é parvo, o raio do moço! - E a rapariga, pisando o pé de Emanuel, calcou o acelerador com força». 
por causa da inoperância das forças da ordem ${ }^{239}$. O narrador nada diz sobre o desfecho da investida claquista. É apenas quando Bernardes, cumprindo o tranquilizador ritual diário que partilha com Lencastre, lê no jornal a notícia do ataque ${ }^{240}$ que o leitor confirma a existência de um padrão destrutivo que permanece impune, protagonizado pelos adeptos, e fica a conhecer a dimensão do incidente (que incluiu «um segurança desaparecido", p. 147 ${ }^{241}$. O narrador abdica, mais uma vez, da sua prerrogativa de voz omnisciente, preferindo que dados ficcionais relevantes para a economia narrativa sejam aduzidos pelo DD das suas personagens, estratégia que redunda num acréscimo estrondoso de ruído.

\subsection{Variações sobre Mofina Mendes}

São dois os eixos temáticos que MC convoca no romance em análise, cujo objetivo é esboçar um retrato de um país que, no limiar do século XXI, se aliena pelo ruído: a voz e o queixume, ambos recorrentes, excessivos, improdutivos. Foi já feita uma aproximação global ao primeiro. Cumpre agora debruçar-me sobre o segundo ${ }^{242}$.

A irrupção das palavras de Mofina Mendes pela voz de Eleutério, numa versão atualizada que lamenta prosaicamente a queda do seu bidão de mel, introduz uma nota de estranheza no romance. Em seguida, é o próprio narrador quem convoca a pastora vicentina, que aliás partilha com a leiteira de La Fontaine e o brâmane de uma fábula indiana uma característica muito humana: o sonhar acordado. Todavia, estas personagens imprudentes veem os seus projetos de riqueza e sucesso esfumar-se,

239 Cf. Fantasia..., p. 109: «E nisto, ainda muito sumidas ao longe, ouvem-se, enfim, as sirenes da polícia”.

240 Cf. Fantasia..., p. 146: "- Já viste que o grupo de adeptos do... [...] passou pela estação de serviço de ...[...] E deixou aquilo tudo numa lástima? Outra vez!».

241 Os coronéis postulam "uma guerra para dar vazão» à violência revelada pelos claquistas. "E chanfalhada! Chanfalhada pra cima!» (147).

242 A propósito dos dois coronéis, M.A. Seixo refere «a dissonância dos projectos de vida e do seu confronto com o recente passado de evolução gloriosa deslustrada e de pechisbeque» (2004: 112). 
acabando por permanecer de mãos vazias ${ }^{243}$. O discurso de Mofina torna-se um segundo vetor do leitmotiv declinado em vários tons ao longo de Fantasia...: primeiro é Eleutério, que entorna o bidão de mel porque atende o telemóvel244; depois, Emanuel, cujos pensamentos surgem na sequência da narração que Irina faz da anterior desgraça de Eleutério com o negócio da areia ${ }^{245}$; em seguida, é a vez do taberneiro de Pias que assiste à tagarelice do pastor trapaceiro, o qual, enquanto se vangloria de ter enganado os Lencastre, vai «sonhando alto e bebendo. E quando acabou de beber, acabou também de sonhar» (43) ${ }^{246}$. É então a vez de Emanuel perceber o desvario da sua ambição (inventar uma extraordinária abertura de xadrez) e descer "ao real", na sequência de uma torrente de pensamentos irrealistas $(100)^{247}$; Maria José quase se deixa seduzir pelo discurso do locutor de rádio ${ }^{248}$; pela voz de Emanuel-narrador, num dos planos hipodiegéticos frequentes no romance, são relatadas as palavras finais do comandante da escuna, que se vai lançar ao mar, "amarrado a uma bigorna" (119) ${ }^{249}$; finalmente, verbalizando o desalento de não ter encontrado nenhum pote de ouro no monte dos Lencastre, Felismina sublinha a diferença entre o tempo do afortunado lavrador do Monte

243 Vendo o seu pote de azeite caído no chão, devido à atitude incauta de bailar enquanto o transportava à cabeça, diz Mofina Mendes: "Por mais que a dita m'engeite,/ pastores, não me deis guerra;/ que todo o humano deleite,/ como o meu pote d'azeite,/ há-de dar consigo em terra" (Vicente, 1984, vol. I: 116).

244 Cf. Fantasia..., pp. 13-4: (em DD) "Sendo-me a dita cruel, senhores, não me deis guerra: que todo o humano aranzel, como o meu bidão de mel, há-de dar consigo em terra"».

245 Cf. Fantasia..., p. 37: (em DD) «Pensou o rapaz: "Por mais que a dita o descreia, senhora, não lhe deis mágoa. Que a humanal verborreia, como o camião de areia, há-de dar consigo n'água." ". Antes, pressentindo o desfecho, Emanuel tinha suplicado a Irina que suspendesse a narração: «- Não, por favor, pare, não me diga...» (37).

246 No discurso do narrador, com duas ilhotas textuais: «Nesta matéria, reflectiu soturnamente o taberneiro que seria boa ocasião para uns versos em que "mossa" rimasse com "dar consigo na fossa"” (43).

247 Cf. Fantasia..., p. 100: (em DD) «(...) Suspirando e pensando, "se me ferir a ventura, mestres não me deis mais guerra, que toda a humanal candura, como esta minha abertura, há-de dar consigo em terra"”. Neste caso, a voz não funciona como gatilho.

248 Cf. Fantasia..., p. 102: (em DD) «Se eu fosse dar-lhe ouvidos, onde é que esses projectos me levariam? Davam comigo em terra, seguramente».

249 Cf. Fantasia..., p. 119: (em DD) "Mas antes disso ainda conseguiu ganir: "Por mais que me enjeite a sorte, é melhor não disparar, um marujo bruto e forte, com o meu altivo porte, há-de dar o corpo ao mar"». 
dos Chocalhos e o tempo atual, em que "é só desgraças» (130). O mesmo parece sentir Figueiredo, cujo desatado pranto, incompreensível para Emanuel (e também para o leitor...) parece confirmar essa máxima (152-4): o infortúnio toca a todos. Graças ao DD, o narrador demonstra que é a voz - verbalizada, interior ou escrita - que desencadeia a desgraça, ou seja, a maldição de Mofina comprova o efeito deletério da loquacidade.

A reprodução direta das palavras das personagens sublinha a vacuidade dos discursos palavrosos, uma suposta característica identitária portuguesa: incapazes de sermos empreendedores, embalamo-nos em sonhos desmesurados que redundam sistematicamente em fracassos, sublinhados por lamentações inconsequentes. Assim, em Fantasia..., o narrador recupera um mito literarizado que pertence à nossa memória coletiva como "intertexto de referência» ${ }^{250}$, recriando-o sobretudo através dos mecanismos de reprodução de palavras, visto que a causadora dos descasos nacionais é essa voz excessiva e omnipresente.

Para além das desafortunadas personagens acima enumeradas, que verbalizam a desdita de ver esboroar-se os seus planos de grandeza, praticamente nenhuma outra no romance leva um projeto até ao fim nem parece aperceber-se da inércia que a paralisa: Bernardes entrega-se diariamente a um ócio estéril; Lencastre, vendo gorados os sonhos pessoais de vastidão oceânica (168-9), desfaz todas as manhãs, à maneira de Penélope, o trabalho que no dia anterior tinha consagrado à miniatura do Galeão Grande (146); os dois passam os dias a comentar a atualidade, mas nenhum deles foi nem é modelo de conduta; sobre a tese que está a elaborar, afirma Maria das Dores que vai "encanando a perna à rã» (186); Emanuel, o andarilho de boa índole, prefere o registo onírico à realidade $(113-9)^{251}$.

As figuras ficcionais que acabei de referir, para quem viver se torna um "gram trabalho», habitam num país ruidoso e inepto, mas não de-

250 Cf. supra 2.3.

251 A incapacidade de autocrítica da personagem - quiçá devido à sua juventude - está patente nas palavras que profere quando começa a contar mais uma das suas aventuras a Angelina: "A minha disposição é acima de tudo empreendedora, do estilo: o que é que eu faço disto, ou com isto, ou apesar disto?» (113). 
têm o monopólio da infelicidade nem da vozearia. De entre a multidão de personagens de Fantasia..., passo a evocar aquelas que, em meu entender, dão um contributo indispensável à tese do narrador, ajudando a construir pelo discurso imagens disfóricas de um certo Portugal contemporâneo.

\subsection{Acordes de um país tagarela}

Entre a geração que experimentou o regime salazarista e agora está acomodada (os coronéis e respetivas esposas) e a que enriqueceu rapidamente, tirando partido da nova realidade nacional pós-revolucionária (Januário), encontram-se os jovens do Portugal do novo milénio. O retrato que deles oferece o narrador não é muito abonatório: Sandra, Angelina, Nelson, Neusa, Tiago, Soraia Marina e Tânia são os rostos de uma geração que nasceu depois de Abril de 74 (não tendo tido, por isso, a experiência da ditadura nem da guerra colonial) e que enferma já de muitos dos males que o narrador denuncia nos adultos: a loquacidade, a inépcia, a ignorância, a presunção, a incivilidade.

A voz de Sandra, a jovem da província, surge no romance em todas as formas de RD (à semelhança do que acontece com o pai, Januário), sendo a presença em DD a mais representativa. Se é graças ao discurso do narrador que ficamos a saber que masca pastilha elástica com pouca elegância (47), cuspindo-a sem cerimónia (47), e conduz o seu Smart - de acordo com a descrição demolidora do narrador - "com a perícia volteadora duma profissional de carrinhos de feira» (47), é pela reprodução das suas próprias palavras que a personagem se revela plenamente: em DD, mostra ser adepta das aféreses («- 'bora!», p. 47) e dos bordões de linguagem da moda («- É assim», p. 48), da música popular de Soraia Marina (48) e dos relógios do rato Mickey (49). É de Sandra a voz de um excerto que testemunha a vitalidade criativa de $\mathrm{MC}$, no que ao $\mathrm{RD}$ diz respeito. Querendo vangloriar-se perante o mestre de xadrez acabado de chegar a Grudemil, o seu discurso começa em DIL (49), passa para DD, sem parágrafo nem travessão (50), 
continua em DDL (50) e em modo híbrido (50), terminando em DD canónico $(50)^{252}$ :

E Sandra continuou: o grande entusiasta ali de Grudemil era o Nunes Norberto, o Nonó, que até tinha livros e tudo. Conhecia? Ah, não? Pois fora ele quem tinha mandado a carta. E concebera toda a organização da simultânea, as consultas de astrologia, enfim, "os momentos culturais", mas fora impedido de vir, por causa dum assunto de computadores e da net. O rapaz tirava músicas e distribuía-as, a um preço simbólico. Tinha boas aparelhagens em casa, um grande investimento, e em se querendo, ia-se lá e trazia-se. Mas a Judiciária apareceu, fez buscas, incomodou toda a gente, apreendeu o material e levou o Nonó. Está em Caxias. O pai de Sandra tinha metido uns empenhos, e tal, mas até agora, nada. O rapaz atrás das grades e a mãe dele chorosa. Injustiça!, concluía Sandra, as canções, a música deviam ser de toda a gente, como as esferográficas, os clips e os isqueiros. O primeiro que chegar pega e leva. Agora esta coisa de estar a proteger o egoísmo duns tipos que lá por serem autores só querem é lucro, ganhuça, ganhuça, é que, francamente, não estava certo. Sandra rematava, com um suspiro:

- Ainda há muita coisa a aperfeiçoar na nossa democracia...

Esta avalanche verbal revela uma jovem pretensiosa e ignorante, imbuída das características de uma sociedade que assimila a astrologia a eventos culturais, recorre ao suborno e despreza ostensivamente a propriedade intelectual (50).

Nelson e as duas figuras-satélite Neusa e Tiago revelam uma outra faceta da juventude portuguesa. A voz do filho de Lencastre e Maria José surge em cinco das formas de $\mathrm{RD}$ recenseadas (apenas está ausente no discurso do narrador) e protagoniza dois momentos fundamentais do romance. No mais extenso DD de Fantasia... (73-5), a personagem revela

252 Para as ocorrências em modo híbrido, cf. Anexo 5, Tabela 2. 
as idiossincrasias de uma certa camada populacional adultescente ${ }^{253}$. Com mais de quarenta anos, mantém tiques linguísticos («linguagem viva», p. 73), comportamentais e ideológicos de um jovem pretensamente revolucionário ${ }^{254}$ : bordões de linguagem ("É assim», p. 73), traços de linguagem oral ("tá", "ó", p. 73), registos de linguagem não vigiados ("caraças", p. 75) e desrespeitadores das regras gramaticais ("quem é que liga a isso da gramática», p. 75) 255; usa roupa de couro, rabo-de-cavalo, piercings e fuma substâncias ilícitas; cultor do $h i p$ - $h o p$, considera-se vanguardista («eu é que não fossilizei no tempo», p. 73), iconoclasta (contesta as ideias burguesas e a sua arte tradicionalista, defende ideias de esquerda e aprecia os revolucionários da América Latina, p. 74), criativo ("lá está o meu tag", p. 74; "é tudo do simbólico", p. 74). Ferozmente crítico do sistema e das suas regras, vive de expedientes e do dinheiro que vai conseguindo obter da mãe, às escondidas do patricarca. E, no final do longo discurso que profere ante os pais, ameaça denunciá-los, na televisão, por causa da agressão de que foi alvo. Também a voz de Nelson se metamorfoseia, de "vozeirão cavernoso» em soluços (75). A estratégia escolhida pelo narrador - deixar Nelson revelar-se, pelas suas próprias palavras, dando simultaneamente eco das reações dos progenitores - confere verosimilhança à personagem e oferece ao leitor um texto riquíssimo, quer do ponto de vista linguístico quer social e cultural.

Este discurso oco, inconsequente, que sublinha a incoerência entre o que diz e o que faz a personagem ${ }^{256}$, repleto de lugares-comuns sobre as relações familiares, a política, a sociedade e a arte, é retomado no diálogo que se estabelece entre Nelson, a nova namorada e Tiago. Aliás, é também

253 Decalque de um neologismo inglês, cunhado em 2004, que designa os jovens adultos incapazes de se autonomizarem. Esta tendência em crescimento configuraria mesmo uma situação de “Peter Pandemic» (Tierney: 2004). Entre nós, surgiu a designação "geração-canguru».

${ }^{254}$ M. Alzira Seixo descreve a personagem como um «quarentão esquerdista de rabo de cavalo" (2004: 112).

255 Sobre o discurso de Nelson, diz C. O. Martins constituir «uma peça admirável de realismo e de cómico, pelo poder de captação de um certo registo urbano e marginal da linguagem» (2007: 269).

256 Cf. Fantasia..., p. 78 : "Mas por onde começar, se Nelson fazia gestos com o garfo na mão direita, à americana, e palitava os dentes com a unha, à antiga portuguesa?». 
em DD que Nelson evoca, junto dos companheiros de viagem, o confronto com o pai (159). Neusa, a artista amante do "ready-made», que transfigura «caricas» e «caracóis» (162) em instalações artísticas, surge sobretudo em DD. Os verbos introdutores do RD sublinham o destempero das suas reações ("entusiasmou-se», p. 163; "quase gritava de entusiasmo», p. 164; "'gritou», p. 224). As inconsistências da personagem são reveladas pelo narrador (guarda a espada gótica que usa no nariz "numa caixinha de gel cor-de-rosa», p. 161; ressona "num falsete gaiteiro», p. 167; produz uma arte supostamente iconoclasta, mas pensa que a deusa que lhe aparece é «a Nossa Senhora"e está disposta a converter-se e a tirar partido mediático disso, p. 224).

Tiago tem uma presença numericamente pouco significativa, mas completa o trio de jovens urbanos contemporâneos. A sua voz ecoa sobretudo em DD e duas vezes em DIL, revelando traços comuns aos dos amigos (bordões de linguagem, registo não vigiado, frases sentenciosas, vazio de conteúdo). A intervenção mais impressiva da personagem (163-4) não se enquadra em nenhuma das formas de RD definidas, como aliás já foi referido ${ }^{257}$ : o narrador assume a responsabilidade de resumir o discurso de Tiago, que é fundamental porquanto sintetiza as ideias que ele esboçou para guiões cinematográficos que finalmente deem ao cinema português aquilo de que precisa - «acção, pá» (163)²58.

Este rapaz de cabelo oxigenado, vaidoso e aparentemente seguro de si (mas, na verdade, "procurando numa obsessão doentia o exclusivo da atenção", p. 158), completa o trio de artistas que, à semelhança dos adultos, se deleita a debitar opiniões, mas leva uma vida completamente improdutiva. A opinião crítica do narrador sobre estes três pseudoartistas é sugerida, por exemplo, em discurso narrativizado 259 ou declarada em DD, quando conversa com Maria José 260 .

257 Cf. supra 1.2.2.

258 Os três parágrafos dedicados ao enredo revelam a sua indigência, a imitação inane do cinema norte-americano (com dez referências a serial killers e três flash-backs, perseguições policiais e facas ensanguentadas).

259 Cf. Fantasia..., p. 162: «E Nelson, entre vapores odoríficos [...] como a conversa tocava o artístico".

260 Cf. Fantasia..., p. 178: “[Neusa] Dedica-se agora às instalações e ao efémero. O efémero é uma forma muito hábil de fugir à crítica porvindoura. Creio que é bacharel em 
Tânia, a jornalista estagiária, tem um emprego, mas a sua conduta não é profissional (208-9) e, apesar da presunção (em DI, "declarou que, na sua opinião", p. 208), revela uma extraordinária ignorância no texto que redige depois de entrevistar Emanuel. A sua classe profissional, representada também por outro colega de Beja, surge no romance como impreparada, presunçosa e néscia (209-10), características reveladas essencialmente em $\mathrm{DD}^{261}$.

Em síntese, os jovens que percorrem o romance são fruto de uma sociedade que está a perder a memória cultural, desrespeita a sua herança linguística e se compraz na preguiça, no imediatismo e no mediatismo ${ }^{262}$.

A submissão do país à tirania mediática é parodiada no episódio da telenovela que Bernardes vê na televisão (137-9): no discurso do narrador, são sublinhados a impreparação das atrizes e da equipa técnica, o mau gosto do cenário e o deficiente domínio da língua portuguesa. Mas é em DD que o leitor se apercebe da indigência quer das falas quer da trama narrativa, intrincada até ao inimaginável com a intenção de alongar o programa e, deste modo, rendibilizar o investimento feito, prática comum desse tipo de lixo televisivo.

A omnipresença mediática no país - materializada em Fantasia... na ameaça de Nelson de "telefonar pràs televisões" a queixar-se do pai (75), na novela que, aparentemente, Bernardes se farta "de papar» (139), nos pensamentos de Neusa, quando vê a deusa que ela toma por Nossa Senhora (224) - expressa-se ainda no DD de Bernardes quando, a propósito de uma das histórias narradas por Lencastre, faz referência a Benjamim, um sem-abrigo que surgiu numa reportagem televisiva (170): o narrador mostra, assim, que a TV se interessa por aquilo que é suscetível de captar a atenção (o tal sem-abrigo, comenta Bernardes, "até tinha uma casa

psicologia criativa, ou coisa assim». O narrador concede ainda a palavra ao tio de Emanuel que, em DD, reprova a vandalização das placas de sinalização, da autoria de Tiago e Nelson: "Ele já não há mão nisto...» (165).

261 Cf. supra nota 73.

262 Este narrador que traça um retrato tão sombrio da juventude coeva faz pensar em Rupert, o especialista em "Tensões etárias" de $E$ se tivesse a bondade de me dizer porquê?, que se confronta com jovens que pretendem exterminar os velhos e pertencem a uma geração "Desenvolta, palavrosa, azougada, sentenciosa... mas iletrada..." (1996: 96). 
de cartão jeitosa", p. 170), mas desdenha do seu papel de denúncia e de promoção da transformação social ${ }^{263}$, num país a tirar plenamente partido do progresso do início do século XXI (telemóveis, grandes superfícies, piscinas no Alentejo), onde há contudo quem não tenha um lar.

Não posso deixar de voltar a chamar, a este texto, Felismina, a empregada do casal Bernardes já evocada por causa das variações a partir de Mofina Mendes. A velha alentejana surge sobretudo em DD (dez ocorrências) e assume particular relevância por ser a única interlocutora de Eleutério e Desidério, aquando da escavação da piscina, e a única testemunha da destruição das ânforas e mosaicos árabes, que aliás encoraja, depois de uma negociação renhida com os dois trabalhadores: é em DD que assistimos quer à revelação da descoberta que Eleutério e Desidério haviam feito, quer à primeira apreciação do achado, quer à sua subsequente desvalorização e ao queixume final ${ }^{264}$. Mais uma vez, a estratégia do narrador é deixar a cena às suas personagens que, neste episódio, devido à ignorância e à ganância, destroem com grande entusiasmo um vestígio arquitetónico seguramente de grande valor histórico e patrimonial.

As "Outras vozes» intervêm em todas as formas de RD, no romance, predominando o DD (quarenta e duas ocorrências). Vou referir sucintamente as falas que se revelam mais produtivas para a ilustração da tese do país verborreico, néscio, vulgar e dado às lamentações: em primeiro lugar, Soraia Marina, a cantora popular (dita "pimba"), cujas canções de rima em "ar», apresentadas em DD, agradam tanto aos seus compatriotas (21, 54, 126); depois, o comum empregado português («Costuma acontecer que o pessoal não está todo disponível», p. 122), em modo híbrido, cujo discurso sublinha a inoperância, a desresponsabilização e a vitimização habituais de quem tem um serviço a prestar («solene e mártir», p. 122); finalmente, Irina, a namorada moldava de Eleutério, cujas palavras são

263 MC acredita na responsabilidade social dos jornalistas, considerando que o ensino, o jornalismo e as elites devem ser espaços de crítica. Infelizmente, considera o escritor, isso não acontece (L. M. Faria, 2003: 47).

264 Cf. Fantasia..., pp. 128: "Se o coronel desconfia que vocês deram cabo dos potes dos mouros vai praí um vendaval que ai ninos!»; 129: "Isto é que vai para aqui um tesouro..."; 129: "- Sacanas dos mouros tinham tempo pra tudo. Não deixaram foi nada prà gente»; 130: "Agora aqui é só desgraças". 
reproduzidas num DD verosímil (que procura reproduzir as dificuldades linguísticas da rapariga, pp. 36 e 38) e depois em DI e em DIL, sendo a organização discursiva da responsabilidade do narrador (36). A relevância desta personagem na obra decorre de um facto atestado em Portugal, a partir da década de 90 do século passado: o país tornou-se destino de imigração, sobretudo para populações oriundas dos países de Leste recém-saídos da órbita soviética.

Essa nova realidade social surge no romance com Irina e Natacha, a empregada de Januário. Ambas se encontram em situação de fragilidade social e económica. No entanto, se Irina, a moldava cujo discurso em português nos é dado ouvir, parece ter conquistado alguma autonomia e integração social no bordel onde abundam "construtores civis»e "mulheres fatais»(36), a russa Natacha, pelo contrário, foi levada por Januário do prostíbulo que ele "orientava» (57) para o cativeiro da sua mansão decorada pela Xuxu Montevedro e Castro (55): sem passaporte, sem domínio da língua (a situação é relatada em DD por Januário, que explora a imigrante), apesar de alegadamente ser juíza (57), encontra-se à margem da lei, completamente à mercê do empresário sem escrúpulos. Um país que, durante décadas, conheceu a sangria da emigração em grande escala parece, em 2003, ter esquecido a lição, replicando com os estrangeiros recém-chegados os comportamentos desumanos que os outrora expatriados veementemente verberavam.

Antes de passar à proposta de didatização, não posso deixar de referir uma última questão, evocada em 2.3.: a referência aos ciganos, em Fantasia...

O Outro estrangeiro - caro objeto de estudo da Imagologia - surge representado de duas formas, no romance. Por um lado, nos imigrantes, personificados em Irina e Natacha: ainda que caracterizadas sucintamente, configuram-se como um alter (Moura, 1998: 53), uma vez que as duas mulheres se encaixam no perfil dos imigrantes de Leste: gente em grande medida com habilitações elevadas e abnegada capacidade de trabalho, habituada a sobreviver em condições duríssimas; chegada a este $E l$ Dorado acalentando sonhos de sucesso pessoal e social, viu-se frequentemente confrontada com situações de exploração e marginalidade, devido ao 
insuficiente domínio do português e a dificuldades legais. Estas duas figuras femininas, portanto, reproduzem o estereótipo do imigrante, bem distinto da imagem que países como a França ou a Alemanha tinham do imigrante português.

Já os ciganos desempenham um papel diferente. Eles são evocados, em DD (aparentemente por Lencastre), o que vai desencadear a recitação, por todos os elementos dos dois casais, de um poema de António de Macedo Papança (131-2)265. O texto poético, aprendido por todos na juventude - sinal inequívoco da vitalidade do estereótipo, mesmo nas lonjuras de Pangim (132) -, condensa a imagem forjada pelo grupo sobre esse alter: a sociedade gregária e nómada, a lazeira, as feiras, o exotismo, bem como a discriminação de que são alvo. A suposta presença desse grupo étnico perto do monte suscita grande inquietação na intrépida Maria das Dores (134), que teme a concretização da profecia poética: "Hás-de ver tudo, se os maltratares,/ lambido em chamas por esses ares ", (132). No entanto, a ameaça latente que os ciganos corporizam acaba por não se concretizar. De certa forma, o narrador subverte o estereótipo (que em vez de confirmar uma ideologia abre caminho a uma visão utópica desse grupo social266) e derroga as expectativas criadas, pois a destruição pelo fogo não é causada por eles, mas pela claque portuguesa ${ }^{267}$ : afinal, o vandalismo tem a sua génese entre nós - as chamas foram ateadas pelos claquistas quadrúpedes.

$\mathrm{O} \mathrm{RD}$, como acabo de demonstrar com alguns dos inesgotáveis exemplos do romance, contribui inequívoca e expressivamente para desenhar uma nova paisagem social portuguesa, da qual o narrador se distancia criticamente. Os falsos «eus» saídos da pena de MC ${ }^{268}$ - jovens urbanos

265 António de Macedo Papança, Conde de Monsaraz (1852-1913). Alentejano cultor das artes poéticas.

http://forumpatria.com/cultura-e-patrimonio-portugues/antonio-de-macedo-papanca-conde-de-monsaraz/

266 Cf. J.-M. Moura, 1998.

267 Cf. Fantasia..., pp. 109: «(...) o crepitar das chamas e incertos clarões rubros» e 146: "Tudo derrubado, tudo partido, um fogaréu tremendo» (DD de Bernardes).

268 Expressão do escritor em entrevista a Cotrim (1996), sobre a relação entre realidade e ficção. É a epígrafe de 3. 
ou da província, mão-de-obra assalariada, chicos-espertos, jornalistas, atores de telenovela, imigrantes, sem-abrigo, representantes da "velha guarda” - compõem uma fantasia musical que muito sintomaticamente se sustenta pela sonoridade ensurdecedora e obsessiva da palavra, sob a forma de DD, DI, DIL, DDL e reprodução de palavras no discurso do narrador, confirmando as hipóteses de partida desta investigação: os mecanismos de reprodução de palavras, em Fantasia..., são o sustentáculo da tese de um narrador que não se identifica com o país em que vive. No entanto, ele não se restringe ao papel de maestro da orquestra dissonante que ecoa em Portugal, compondo, ele mesmo os seus acordes: basta atentar na descrição antológica da festa em Grudemil (44-54) - com os seus "medonhos arcos de madeira", as "farpelas domingueiras de marca", os «medonhos balões das crianças choronas», os «vozeiros alegrotes», as «musiquetas mais semiscarúnfias das sete partidas do mundo» (exemplos da página 44), o aviso "que irradiava brilhozinhos furta-cores» (46), os copos que são transportados em sacos de plástico (47), os tabuleiros de xadrez comprados nos chineses (51), a detenção do "responsável cultural» (54) - para percebermos o seu olhar reprovador ante o que considera ser um aviltamento generalizado do país.

Quando questionado sobre que livro recomendaria para introduzir a sua literatura num curso de Letras, MC respondeu, muito justamente:

"Talvez a Fantasia para Dois Coronéis e uma Piscina, porque esse romance (eu chamei-lhe "cronovelema") lida, parodiando, com a narrativa e as suas categorias, com a prosa portuguesa, os seus ritmos e as suas espessuras, com camadas de águas geladas ou mornas, ensolaradas ou sombrias, no que procurou ser um desconcertante festival de ilusionismo» (Santos, 2009: 266).

Poderá esse «ilusionismo", exigente até para um falante nativo ${ }^{269}$, ser compreendido e fruído por alunos estrangeiros? Será pertinente estudar

269 M. A. Seixo é de opinião de que o romance é acessível a todos, pois quem não conhece as referências cultas «diverte-se com uma interpretação mais à letra, seguindo o 
um texto literário deste grau de dificuldade num curso de PLE e, com ele, desencadear uma reflexão metalinguística sobre o RD? Como concretizar o estudo do papel da reprodução de palavras na configuração de imagens identitárias, sem instrumentalizar nem sacralizar o romance, concedendo aos alunos a possibilidade de exercerem a sua função de recetores críticos consistentes e, dessa forma, darem o seu contributo único para novas leituras de Fantasia...? ${ }^{270}$

\subsection{Proposta de didatização}

\subsubsection{Alguns pressupostos teóricos}

O ensino de línguas - nomeadamente, estrangeiras - envolve alguns pressupostos teóricos que nortearam as minhas opções pedagógico-didáticas fundamentais, pelo que passo a expô-los sucintamente.

\section{Língua e literatura na aula de línguas}

Aprender uma língua - materna ou estrangeira - significa não apenas saber utilizá-la, nas interações diárias, mas igualmente saber como ela funciona. No que diz respeito à aprendizagem da LM, partilho da convicção de que uma dimensão instrumental no ensino é fulcral (Costa, 2009:

percurso das personagens bizarras que volteiam em torno dos alapardados coronéis» (2004: 112). Uma das epígrafes do já citado romance Era bom que trocássemos umas ideias sobre o assunto é retirada do Orto do Esposo: "Lea per este livro o estudioso e achará com que se deleite, lea o enfadado e achará com que se demova, lea o simplis e achará com que se entenda, lea o triste e achará com que se alegre» (p. 7). Estas palavras poderiam aplicar-se também a Fantasia...

270 Cf. Silva: «(...) Aprendemos, enfim, a retirar ao texto literário certa aura de sacralidade, sabendo que, sem a nossa leitura, ele terá sempre uma existência defectiva, pois que nenhum texto fala por si. [...] O leitor tem de se apropriar do texto - não há outro modo de ler, pese embora aos defensores ortodoxos do método histórico-literário -, mas não pode nem deve expropriar o texto a seu bel-prazer» (2010: 182-3). 
36), sendo que uma reflexão abrangente e integradora sobre as regras de funcionamento e de uso da língua é essencial para o desenvolvimento das competências linguísticas e comunicativas dos alunos (A. M. Lopes, 2006: 76). Este mesmo princípio encontra-se enunciado no Quadro relativamente às línguas estrangeiras ${ }^{271}$. No processo de ensino-aprendizagem de línguas, portanto, o conhecimento explicitado da gramática revela-se um instrumento valioso no percurso de aprendizagem dos discentes.

Outra questão pertinente prende-se com os materiais que devem entrar na sala de aula. Considero que, na aula de PLE, se deve utilizar a mesma estratégia que A. M. Lopes preconiza para a de LM: aos alunos deve ser facultado um leque variado de textos de diferentes matrizes discursivas - dos que têm fins utilitários aos que estimulam, nos discentes, competências de natureza filosófica, científica e estética como, e.g., os textos literários (2006: 77).

Como articular então a imprescindível abordagem metalinguística com o estudo de textos literários? Gramática e literatura têm estado muitas vezes de costas voltadas, mas vários teóricos concordam no repúdio de uma separação considerada artificial e estéril entre o ensino-aprendizagem da língua materna e o da literatura. A essa falsa dicotomia contrapõem uma interdisciplinaridade ancorada na relação indissociável e reciprocamente fecunda que existe entre os dois domínios. O já referido postulado de Coseriu, retomado por Aguiar e Silva - o texto literário é o espaço onde a língua revela todas as suas potencialidades expressivas e criativas $^{272}$-, conduz necessariamente à assunção de que, na LM, a literatura deve fazer parte de todo o percurso de estudos (F. I. Fonseca, 2000: 41; Duarte, 2003: 400-2). Sem negar as funcionalidades pedagógicas de que se revestem os textos de valência predominantemente utilitária, a obra literária oferece não apenas a possibilidade de uma "relação autotélica

271 Cf. p. 191 do QECRL: «Nalguns casos, a aprendizagem de uma língua estrangeira tem como finalidade, acima de tudo, dotar o aprendente de um conhecimento declarativo (p. ex.: da gramática ou da literatura, ou de certas características culturais de um país estrangeiro)». O meu público-alvo procura um ensino formal da LP numa universidade e, por isso, integra-se no perfil definido.

272 Cf. supra 2.1. 
com a língua" (F. I. Fonseca, 2000: 42) como também de um percurso de autognose e de relação crítica com os outros e com o mundo. No caso específico da polifonia discursiva, o texto ficcional é o local por excelência onde se cruzam inúmeras vozes (F. I. Fonseca, 2000: 39; Duarte, 2003: 22), devendo por isso integrar as várias etapas de aprendizagem dos alunos 273 .

Arredada durante muito tempo da aula de LE - quer substituída por documentos autênticos ou textos eminentemente funcionais quer frequentemente subalternizada à abordagem de conteúdos gramaticais e culturais ${ }^{274}$ -, a literatura recuperou aí um lugar de pleno direito ${ }^{275}$ : autêntico - i.e., não elaborado especificamente com fins pedagógicos (Sequeira, 2003: 65; Bizarro, 2008: 359; Takahashi, 2008: 22; Puren, 2010) -, veículo de um amplo, variado e enriquecedor input linguístico e cultural (Fillola, 2004: 3), polissémico e criativo (Bolaños \& González, 2004: 226), o texto literário permite pôr em marcha conhecimentos prévios dos alunos e promover diferentes estratégias de leitura, congregando a possibilidade de desenvolver não apenas competências comunicativas, culturais e estéticas (Bizarro, 2008: 360; Fillola, 2004: 3, 34) como também a cooperação e a interação entre os discentes (Sequeira, 2003: 72)276.

273 Cf. F. I. Fonseca: «Para além de uma reconhecida função catártica, a ficção tem uma capacidade heurística fundamental na sua qualidade de intensificar a capacidade de acesso, através da linguagem, a "mundos possíveis" alternativos" (2000: 42). Cf. ainda Silva: "A literatura é também jogo, catarse, evasão, terapêutica, mas é, conjuntamente com tudo isto e acima de tudo isto, forma de conhecimento" (2010: 186).

274 Esta instrumentalização do texto literário é criticada por vários teóricos. Sobre esta questão, veja-se, e.g., Puren (2006: 8-9), Cruz \& Jouët-Pastré (2000, 405) e Takahashi (2008: 72-3).

275 A abordagem comunicativa, a poética do texto, as teorias da receção do discurso literário e a valorização das estratégias de receção e de produção em contexto pedagógico permitiram à literatura voltar à aula de línguas (Fillola, 2004: 1-5).

276 Refletindo sobre o ensino de Espanhol LE, Fillola considera que ler é uma experiência simultaneamente linguística, estética e pragmática. A personalidade do recetor-leitor entra em interação com o texto e permite a expressão de opiniões, reações e sentimentos (2004: 28). Também Puren salienta a importância de um trabalho de projeto em LE, orientado para uma apropriação pessoal do texto literário e para a discussão de pontos de vista entre os alunos (Puren, 2006). Mais tarde, Puren retoma esta temática e realça o "valor seguro» que o texto literário constitui, porque congrega autenticidade e qualidade. Para além disso, segundo afirma, as atuais perspetivas acionais que orientam o ensino-aprendizagem de línguas estrangeiras têm por principal objetivo preparar os alunos para uma coabitação 
Quer se trate de LM quer de LE, é indispensável um diálogo permanente entre linguística e literatura (Bizarro, 2008: 362), ressalvando-se a imprescindibilidade de garantir o estudo do texto literário tendo em conta as suas particularidades expressivas e criativas:

Todo o texto literário, na sua textura, na sua micrologia [...], nos seus significados, no seu ritmo, na sua música, é linguagem verbal, plasmada por norma numa determinada língua natural e regulada pela respectiva gramática (deixo agora de lado as regulações e convenções de ordem não gramatical). Ler, entender, explicar e interpretar um texto pressupõe necessariamente por conseguinte o conhecimento dessa língua - ou da língua das suas eventuais traduções, com as perdas e transformações que são conhecidas -, utilizando as ferramentas linguísticas ou gramaticais adequadas.

O texto literário, porém, co-envolve, na sua produção e na sua recepção [...], múltiplas articulações dialógicas com outros textos, com outras vozes, com outros modelos do mundo, com multiformes forças, tensões e conflitos sociais. Ora o dialogismo textual não pode ser integralmente dilucidado por nenhuma ciência linguística e por isso Bakhtine se referiu reiteradamente à translinguística como o horizonte necessário à leitura e à compreensão dos textos literários. [...] O conceito de translinguística, porém, não é pensável sem o conceito de linguística. (Silva, 2010: $168-9)^{277}$

permanente com pessoas de línguas e culturas diferentes. Os textos literários permitem harmonizar as vertentes intercultural e metacultural (2010).

277 A propósito da referência de Aguiar e Silva às inevitáveis "perdas» e "transformações" decorrentes de qualquer tradução, deixo uma observação que não pode ser aqui desenvolvida: na edição francesa de Fantasia..., cuja imagem de capa vou utilizar na proposta de didatização, pude constatar que nem sempre se mantêm as características que mesclam os diferentes modos de RD no texto original. Confrontei apenas as dezanove ocorrências recenseadas em modo híbrido (cf. Anexo 5, Tabela 2) com as respetivas traduções. Em oito dos exemplos franceses, houve alterações significativas (cf. Fantaisie pour deux colonels et une piscine, 2007, pp. 71, 73, 74, 197, 199, 232, 255, 268). A necessária conformação de um discurso original a uma língua diferente exige o recurso a novas estratégias discursivas, o que pode alterar a sonoridade polifónica dos textos. Esta mudança no registo criativo próprio de um escritor (refiro-me ao caso concreto do RD, que comprovei) parece-me ser um poderoso argumento motivador para a aprendizagem de línguas estrangeiras. Para além disso, poderia ser objeto de reflexão em contexto de aula, caso o público-alvo fosse exclusivamente francófono. 


\section{Competências de leitura em língua estrangeira}

No domínio da leitura em LE, é indispensável uma referência breve ao alcance dessa competência e ao que o QECRL preconiza.

Vários estudos levados a cabo sobre esta área do ensino-aprendizagem de línguas atestaram que a capacidade de ler e de compreender o que se lê se adquire e desenvolve na primeira língua em que se é escolarizado (a LM ou uma LS) ${ }^{278} \mathrm{e}$, por esse motivo, durante muito tempo foi esse o campo preferencial da investigação (Grabe, 2002: 276-7). Relativamente a L2, supunha-se que o aluno, leitor fluente na sua L1, transpusesse essa competência para a nova língua-alvo, no âmbito da qual a leitura era encarada como uma ferramenta e não como objeto de aprendizagem. Os avanços na área da psicologia cognitiva foram determinantes para a didática das línguas, pois permitiram perceber que se adquire uma $\mathrm{L} 1$ recorrendo a mecanismos da memória processual ou implícita e se aprende uma L2 fazendo apelo a mecanismos da memória declarativa ou explícita (Gaonac'h, 2005). Em consequência, é fundamental que, nas atividades de leitura que propõe em L2, o professor tenha em consideração a consciência metalinguística do aluno, bem como as estratégias de aprendizagem que ele já desenvolveu ${ }^{279}$, para o auxiliar a tirar partido dessas competências (Grabe, 2002: 277). Treinar a compreensão da leitura em L2 é fundamental, até porque, para muitos alunos, esse é o fim primeiro que os conduz a uma sala de aula - aprender para ler por imperativos profissionais/académicos ou por puro prazer. Se o grau de proficiência dos alunos é determinante na seleção de estratégias de leitura - alunos mais proficientes variam essas estratégias e, consequentemente, obtêm mais sucesso -, ler muito é determinante para adquirir proficiência.

278 Cf. supra nota 2.

279 Segundo Janzen, estratégias de leitura são "plans for solving problems encountered in constructing meaning" (2002: 287). 
Aprende-se a ler melhor, naturalmente, quando se está exposto a input de qualidade e em quantidade significativa ${ }^{280}$, o que suscita novamente a questão da escolha dos materiais didáticos a utilizar, desta feita nas aulas de L2. Os alunos devem ser confrontados com textos completos, de tipologia variada, que exijam compreensão global, para que desenvolvam estratégias de leitura adequadas e fortaleçam a confiança nas suas capacidades de antecipação e de interpretação ${ }^{281}$ - no fundo, os critérios são essencialmente idênticos aos evocados para a aula de LM.

Na aula de LE, o docente deve propor aos alunos textos com um grau de dificuldade ligeiramente superior ao seu nível de proficiência, para que eles se sintam desafiados e motivados para a leitura ${ }^{282}$. As competências discursivas e literárias que cada um desenvolveu na sua L1 sustentam a construção e consolidação desses novos saberes e ajudam-no a tornar-se um leitor funcional, crítico e criativo, capaz de fruir da leitura de textos escritos na LE que estuda.

A consulta do QECRL, no que diz respeito ao perfil de aprendentes de nível C1, parece-me confirmar que o grau de dificuldade de Fantasia... é compatível com as competências expectáveis em cada uma das vertentes que constituem a competência comunicativa de um utilizador proficiente da língua portuguesa ${ }^{283}$.

280 É um dos argumentos invocados em favor quer da leitura extensiva - que decorre em grande medida fora da sala de aula - quer da que é baseada em conteúdos ou integrada em projetos. Day e Bamford defendem que a leitura intensiva desenvolve competências, mas não promove hábitos de leitura (apud Renandya \& Jacobs, 2002: 299).

281 Brown apresenta os três critérios definidos por Christine Nuttall para escolher textos para os alunos: adequação do conteúdo, explorabilidade, lisibilidade (2001: 314).

282 Segundo Grellet, a simplificação de textos pode torná-los mais difíceis para os alunos, porque lhes extrai mecanismos de redundância essenciais para a compreensão e os inibe de recorrer a sinais não linguísticos para lograr a interpretação: "Reading is a constant process of guessing, and what one brings to the text is often more important than what one finds in it». O que é fundamental é a adequação do grau de complexidade das atividades a propor - que devem ser variadas e flexíveis - e a explicação inequívoca dos objetivos que se pretende alcançar (1981: 7).

283 Cf. Anexo 10, onde estão reproduzidos os principais descritores do Quadro referentes ao nível C1 de proficiência. Sobre o QECRL e os conceitos relativos ao ensino-aprendizagem de línguas, cf. supra 1.1., nomeadamente as notas 27 e 28. 


\subsubsection{Abordagem do RD na aula de PLE de nível C1}

Uma vez que tomei como referência os programas do CAPE de 2010/ 2011, considerei ser coerente preparar a didatização dos conteúdos tendo como possível público-alvo os alunos do nível C1 que frequentaram o referido curso da FLUC nesse ano letivo.

De todos os 118 inscritos, onze fizeram-no no nível superior e concluíram o curso 284 . Não me foi possível apurar as línguas maternas desses discentes. Apenas me foram fornecidos dados sobre as nacionalidades: belga, checa, chinesa, croata, espanhola, francesa, holandesa, indiana, inglesa, japonesa e russa. Na minha aula virtual, portanto, teria de me confrontar com onze alunos e outras tantas nacionalidades, havendo previsivelmente alguns nativos de línguas geneticamente muito longínquas do português. É certo que, em geral, estudantes com este grau de proficiência já dominam outras línguas de alfabeto latino - nomeadamente o inglês - e desenvolveram conhecimentos declarativos facilitadores de novas aprendizagens. Isso, porém, não invalida o enorme esforço exigido a um docente para responder a tamanho desafio com eficácia científica e pedagógica, bem como com sensibilidade para as diferenças culturais ante um público tão heterogéneo.

É chegado o momento de apresentar a minha proposta de didatização, que desenvolvi em cinco etapas. O objetivo geral de partida foi promover a leitura integral do romance e o estudo da forma como a tese do país tagarela se ancora nos mecanismos discursivos de reprodução de palavras. O roteiro da unidade didática encontra-se no Anexo 11.

${ }^{284}$ As informações sobre estes discentes foram-me facultadas pela Secretaria de Assuntos Académicos - Relações Internacionais, via correio eletrónico, a 29 de julho de 2011 . No nível elementar, inscreveram-se 51 alunos e 56 frequentaram o nível intermédio. 


\section{Etapa 1}

Num primeiro momento, seriam desenvolvidas, como motivação para a leitura, as seguintes atividades preparatórias:

- projeção da imagem da capa da tradução francesa (de 2007) de Fantasia...285, ocultando o título, para espoletar o levantamento de hipóteses sobre o tema do livro; depois, registo no quadro do título (bem como do ano de nascimento do escritor), sua explicação (para perceber o grau de apreensão, pelos alunos, da polissemia do nome fantasia) e (eventual) reformulação das hipóteses iniciais;

- projeção da capa da edição portuguesa ${ }^{286}$ e explicação/confronto das duas mensagens icónicas; (eventual) nova reformulação de expectativas de leitura.

Os alunos seriam então convidados a fazer autonomamente a leitura integral da obra, sendo acordado um prazo considerado adequado para todos. A única orientação para essa tarefa seria a preparação de um pequeno comentário oral, para apresentar na aula, sobre as duas capas e o título: os alunos deveriam indicar a que consideravam mais conseguida, explicando a razão, e/ou propor uma capa diferente (apresentando uma fotografia ou um desenho, reproduzido ou original), justificando a opção; deveriam ainda manifestar-se sobre a pertinência do título escolhido pelo autor, tendo em conta a leitura pessoal que tinham feito do romance.

285 As imagens das capas de todas as edições estrangeiras estão disponíveis na página de Mário de Carvalho:

http://www.mariodecarvalho.com/estrangeiro.

286 A imagem da capa da edição da Caminho de 2003 também está disponível na página do escritor:

http://www.mariodecarvalho.com/obras. 


\section{Etapa 2}

Na data fixada, os alunos deveriam começar por pôr em comum os resultados das tarefas realizadas - apresentações orais sobre as capas e o título, assim como propostas para uma nova edição do romance, hipoteticamente nos seus próprios países - e, após a partilha de comentários e opiniões, seriam ainda mostradas e comentadas as capas das edições croata (de 2008) e castelhana (de 2011)287. Um dos objetivos desta atividade seria sensibilizar os alunos (entre os quais estariam falantes de nacionalidades francesa, belga, espanhola e croata) para a relevância dos elementos paratextuais na criação de expectativas de leitura, bem como para o facto de esses elementos resultarem, eles próprios, de escolhas editoriais e eventualmente decorrerem de diferentes sensibilidades culturais.

Discutido o tema central do livro - as personagens que não se calam (possivelmente, alguns alunos fariam referência à atitude crítica do narrador face ao seu país) -, seriam estudadas, em grande grupo, as primeiras páginas do romance ${ }^{288}$, para se atestar onde e de que forma, fazendo ouvir a sua própria voz, o narrador apresenta inicialmente a tese da verborreia e faz uma primeira aproximação à modulação das vozes nacionais. A leitura em voz alta e a análise de texto realçariam as sonoridades, a riqueza e expressividade do léxico e a isotopia essencial - o ruído excessivo e oco das vozes portuguesas ${ }^{289}$.

A transição para o RD far-se-ia pela intermediação de Emanuel, uma voz presente em todo o romance e essencial para a consistência do tecido narrativo. A ficha de trabalho $1^{290}$, a realizar em pares e com posterior correção e discussão em grande grupo, teria dois propósitos essenciais:

287 Cf. supra nota 285.

288 Seriam lidas e comentadas as páginas 11 (linha 1) a 20 (até "e a nutrir triliões de moscas, moscardos e vespas").

289 Sempre que, na proposta de didatização, evoquei linhas de sentido já explanadas (nos pontos 3.1. a 3.4.), optei por não as reproduzir aqui, pois seria redundante.

290 Cf. Anexo 12. Uma das tarefas pedagógicas mais produtivas consiste em partir de atividades práticas para a reflexão metalinguística. Para a elaboração das duas fichas de trabalho, tive em conta sugestões para exploração didática do RD apresentadas por I. M. Duarte (2003: 431ss.). 
convocar conhecimentos prévios dos discentes sobre o DD e o $\mathrm{DI}^{291}$ e promover uma reflexão sobre a indispensabilidade das coordenadas da enunciação quando estão em causa mecanismos de reprodução de palavras. A variação contextual proposta na ficha, a partir de um exemplo do romance, não é exaustiva e funcionaria como ponto de partida para um trabalho conjunto com os alunos, que poderiam, eles próprios, propor diferentes coordenadas enunciativas e encontrar a adequada transposição DD-DI (Duarte, 1999: 116-7). Poderiam ainda ser consultadas gramáticas de português (e.g., de entre as analisadas em 1.3.), tarefa que permitiria desenvolver a autonomia e a capacidade de seleção crítica de materiais de estudo.

A partir dos exercícios propostos nos quadros A., B. e C. da referida ficha de trabalho, seria então feita uma análise do comportamento dos deíticos pessoais, espaciais e temporais, respetivamente, assim como da inviabilidade de reprodução ipsis verbis de um enunciado em DD (e.g., interjeição "ala" proferida por Emanuel); poderiam ainda ser abordadas questões como as fórmulas de tratamento em português - nomeadamente, no diálogo entre Emanuel e Eleutério, onde as personagens poderiam recorrer ao tratamento de $2^{\mathrm{a}}$ pessoa formal ("você» ou "senhor», com a flexão verbal formalmente idêntica à da $3^{\text {a }}$ pessoa do singular), a concordância dos tempos e a substituição, em situações de uso corrente, do Condicional pelo Imperfeito e do Futuro pelo Presente (F. I. Fonseca, 1994: 317).

\section{Etapa 3}

A iniciar o terceiro momento de exploração didática, os alunos seriam levados a notar a presença massiva de enunciados em RD e a articular esse dado com a tese identificada anteriormente. Após um diálogo orientado

291 O RD consta dos programas do CAPE dos níveis elementar e intermédio (cf. Anexo 3). Mesmo que os alunos não tenham frequentado esses níveis na FLUC, será expectável que no nível $\mathrm{C} 1$ dominem este conteúdo. 
sobre a multiplicação de caracteres ficcionais e um rápido percorrer das duzentas e vinte e sete páginas de Fantasia..., já por eles lidas, creio que os discentes conseguiriam concluir que o narrador explora quantitativa e qualitativamente os mecanismos de reprodução do discurso no discurso (sobretudo o DD), como estratégia linguística e narrativa ao serviço da sua intenção crítica. Seria nesse momento resolvida a ficha de trabalho $2^{292}$, em grupos (dois de quatro e um de três alunos), com o auxílio de dicionários. O objetivo seria ampliar o repertório lexical dos discentes e desenvolver as competências de análise/interpretação/manipulação do texto literário, explorando a expressividade da língua portuguesa, sempre em articulação com a mensagem que o narrador veicula no romance. Procurei que os excertos transcritos reproduzissem discurso de personagens relevantes para a configuração de imagens identitárias. A correção coletiva da ficha permitiria trabalhar diferentes possibilidades de introduzir palavras em $\mathrm{RD}^{293}$, confrontar perspetivas de leitura e estilos/sensibilidades de escrita, assim como constatar a importância da voz para a caracterização das personagens - Emanuel, uma voz anónima de Grudemil, Sandra, Januário, Maria das Dores (quer no registo habitual quer tentando moderar os impulsos vernáculos), Angelina, Felismina, Bernardes, Neusa, Nelson e Tiago -, possibilitando a articulação com a etapa seguinte: o exercício relativo a Felismina (para o qual propus o verbo "Lamuriar-se») seria a porta de entrada para a identificação do segundo vetor temático identitário - a lamúria constante, presentificada no romance pelas variações a partir de Gil Vicente ${ }^{294}$. Partindo da fala de Felismina - "Agora aqui é só desgraças» (130) -, seria lida, contextualizada e explicada a fala da pastora Mofina Mendes 295 e, em seguida, proceder-se-ia à leitura e comentário dos excertos de Fantasia... que

292 Cf. Anexo 13.

293 A opção de considerar apenas os verbos dicendi e sentiendi não obsta a que, em contexto pedagógico, fossem explorados verbos com diferentes cargas semânticas.

294 Cf. supra 3.3.

295 Cf. supra nota 243. Em Quando o diabo reza, que MC publicou em 2011, o escritor recria novamente a figura de Mofina na personagem Cíntia: construindo na sua imaginação um futuro radioso, começa a dançar e deixa cair um garrafão de azeite, espalhando-se pelo apartamento "um cheiro a azeitum» (p. 102). 
constituem variações do discurso vicentino (13-4, 37, 43, 100, 102, 119, 152-4). Os alunos seriam convidados a pronunciar-se sobre o grau de consecução dos objetivos de vida das personagens cujo discurso está mais presente no romance. Constatariam que todos falham, à exceção de Januário, o chico-esperto.

\section{Etapa 4}

Far-se-ia, então, um segundo momento de análise textual conjunta. O excerto selecionado começa na página 52 ( $(-\mathrm{O}$ senhor professor desculpe, mas a minha filha Sandra não estava consigo?») e termina na página 60 ( $"$ Volta para trás, malandro! Sê homem, sê homem»)"296. Numa abordagem que atentasse na extraordinária riqueza linguística e expressiva do texto, constatar-se-ia a relevância do RD na configuração da personagem, fazendo a imprescindível articulação com a heterocaracterização verbalizada quer por Lencastre quer por Bernardes (188-9). Creio que os alunos já estariam aptos a relacionar esse retrato com a tese inicial e a intenção crítica do narrador, que se distancia da voz e dos comportamentos de Januário.

Como já referi, ainda que não releve do $\mathrm{RD}$, parece-me essencial a leitura com os alunos do episódio dos claquistas, analisado em 3.2. (cf. Anexo 9).

\section{Etapa 5}

A última fase do estudo de Fantasia... compreenderia dois momentos:

(i) um trabalho em grupo, para analisar a construção das seguintes personagens, graças ao RD 297: Sandra (47-50), Nelson/Neusa/Tiago (158-9 e 1615) e o eletricista da Tubos e Jardins (121-3); a apresentação e discussão dos trabalhos, para revisão (ou lecionação) do DIL e do DDL, constatação das regras canóni-

\footnotetext{
296 Em contexto de aula, recorreria à análise da personagem feita em 3.2.

297 Entre parênteses, as páginas que os alunos deveriam analisar.
} 
cas de reprodução de palavras, levantamento e análise das formas periféricas uma vez que nas falas de todas estas personagens foram recenseados exemplos de modo híbrido; finalmente, preparação e realização de um debate sobre as imagens identitárias de Portugal plasmadas no romance, em confronto com as diferentes mundividências e conceções identitárias nacionais dos alunos;

(ii) uma produção escrita individual - comentário crítico do romance, com referência à experiência pessoal do contacto com portugueses, na situação de imersão em que os alunos se encontram, e confronto da realidade orquestrada no romance com imagens identitárias do país de origem de cada aluno; os textos, depois de corrigidos, seriam lidos e debatidos na aula e seriam pedidas aos alunos sugestões de obras de temática idêntica da autoria de escritores das respetivas nacionalidades; caso houvesse traduções em português dessas propostas de leitura, os alunos poderiam tomar contacto com esses livros também nesta língua.

Naturalmente, estas propostas não esgotam as potencialidades de exploração pedagógica do romance de MC. O discurso de Maria das Dores, e.g., poderia ser ponto de partida para o estudo de expressões feitas ou do campo semântico do insulto (cf. Anexo 8). Bernardes e Lencastre, protótipos do militar, convidam à reflexão sobre as imagens do passado colonial em confronto com a realidade pós-revolucionária. Seria ainda produtivo estabelecer pontes com diferentes configurações discursivas, nomeadamente seguindo a sugestão de Alice Vieira (cf. supra nota 104) e levando para a aula de PLE a canção "Movimento Perpétuo Associativo", dos Deolinda, com a finalidade de traçar o retrato do país que, também pela voz, nela é evocado, ou promovendo o visionamento e posterior discussão de filmes como "Aquele querido mês de Agosto", de Miguel Gomes (2008), ou «Fantasia Lusitana», de João Canijo (2010).

A unidade didática poderia ter sido concluída com a presença dos alunos numa sessão com o escritor, que esteve na Livraria Almedina, em Coimbra, no dia 15 de dezembro de 2011. A possibilidade de participar numa tertúlia literária, interagindo com o autor do romance estudado nas aulas de PLE, poderia certamente ter-se tornado num estímulo para a leitura de outras obras de Mário de Carvalho. 


\section{O N C L US Ã O}

No final deste percurso de estudo do RD balizado pela Linguística da enunciação/textual e por conceitos que relevam da configuração literária de imagens identitárias, visando uma aplicação didática com estudantes de PLE de nível C1 de proficiência, cumpre fazer o balanço de todas as etapas e uma síntese das conclusões a que cheguei.

O ponto de partida foi o relato de discurso, i.e., as várias formas de reproduzir palavras, com o propósito de perceber a funcionalidade desses mecanismos de citação em Fantasia para dois coronéis e uma piscina, o romance que Mário de Carvalho publicou em 2003 e se apresenta como um manifesto denunciador de um novo traço nacional que, segundo o narrador, está a contaminar a identidade lusa: as falas torrenciais e ocas dos portugueses. Assim, formulei duas questões: que formas de RD tomam corpo numa obra narrativa que parte da verberação da palavra excessiva e qual o posicionamento crítico do narrador perante a realidade ficcional que plasma no seu texto. A minha hipótese latente, formulada após a releitura do romance, era a de que a homologia proposta pela capa da edição da Caminho Portugal transmutado em piscina, ou seja, o universo dos dois coronéis que figuram no título, por metonímia, a representar todo um país - se textualizava preferencialmente mediante os mecanismos de citação. Por isso mesmo, como tarefa prévia, procedi ao registo e à classificação das vozes e dos discursos que atravessam o romance. Os dados obtidos surpreenderam-me pela expressividade numérica e confirmaram a premissa: no romance, é pela representação discursiva da voz que ela se revela em toda a sua vacuidade imoderada. 
Os dois primeiros pontos deste texto foram consagrados ao enquadramento teórico. Em 1., debrucei-me sobre a vertente linguística, assumindo, no início, a heterogeneidade intrínseca da língua e do discurso - a língua tem uma matriz dialogal indissociável da enunciação. Todo o uso linguístico é, de facto, uma reutilização. Em consequência, para além do dialogismo inerente às línguas naturais, sustenta-as e satura-as uma pluralidade de vozes, (re)alimentada em cada situação de atualização. O RD, na verdade, é a marcação da presença de outro(s) no discurso - da dimensão dialógica e polifónica da língua -, pois visa sinalizar quem fala e quem cita. Esta constatação fundamenta a ancoragem teórica escolhida - a Linguística da enunciação/textual -, bem como a subsequente definição dos conceitos operatórios, que recobriram áreas dos três domínios que este trabalho abarca - a Linguística, a Literatura e o ensino de PLE. O DT funcionou como horizonte de referência teórica.

Foram depois balizadas algumas etapas que tem percorrido o complexo caminho do estudo da presença de outras vozes no discurso, desde Platão e Aristóteles até à gramática normativa, desembocando na multiplicidade de correntes atuais, que continuam a abrir linhas de investigação sobre esta problemática. Duas das conclusões dessas referências necessariamente sucintas são as seguintes: a heterogeneidade discursiva revelada pelo RD continua a constituir um desafiante potencial linguístico, pragmático e estético; é um domínio que funciona como interface dos estudos linguísticos e dos estudos literários.

Pensando na aula de PLE, optei em seguida por me ater à definição e exemplificação das formas prototípicas de RD, e.g., DD, DI e DIL. Cada um destes modos de citação de palavras foi definido e ilustrado com exemplos claros retirados de Fantasia... . Sem negar a viabilidade e produtividade da entrada na aula de casos periféricos, considero que a reflexão metalinguística, nesse espaço, deve partir da regra para a exceção. A questão da utilização de exemplos literários - ontologicamente diversos dos fenómenos linguísticos comunicativos - para atestar supostos usos linguísticos mereceu-me duas observações: por um lado, não seria viável fazê-lo de outro modo, uma vez que o objetivo traçado era estudar a presença e a função do RD num romance; por outro, de acordo com 
vários teóricos, os mecanismos de citação funcionam de forma idêntica, num e noutro caso. Cumpre lembrar que as trocas orais quotidianas, em contexto informal, se caracterizam pela escassa estruturação, o que coloca dificuldades acrescidas ao docente que pretenda fazer delas objeto de estudo no âmbito do RD.

A definição da tríade canónica - DD, DI e DIL - permitiu-me concluir o seguinte: não é cientificamente correto nem pragmaticamente produtivo alienar a reprodução de palavras das suas coordenadas enunciativas, sendo por isso redutora toda a definição teórica que se limite às particularidades sintáticas de cada um dos modos de RD, ressalva a ter em conta em contexto pedagógico; em geral, o DD e o DI oferecem-se à análise sem maiores dificuldades de interpretação, enquanto no DIL - encarado neste trabalho como fenómeno discursivo de cariz literário - se torna por vezes difícil delimitar e identificar as vozes que ressoam nos textos; é essencial proscrever os postulados gramaticais do suposto discurso original e da alegada fidelidade de dicto na reprodução de discurso, mesmo que se trate de DD, o que exige uma abordagem pedagógica liberta desses constrangimentos incorretos; sem esquecer que a funcionalidade dos modos de RD decorre do contexto particular em que cada um se atualiza, em geral o DD e o DIL, porque permitem a inclusão de traços oralizantes, revestem-se de especial força mimética e expressiva e, por isso, assumem particular relevo na caracterização de personagens ficcionais.

Os exemplos encontrados no romance exigiram que, logo nessa etapa do trabalho, fossem assinaladas algumas subversões ao cânone (e.g., DD sem travessão), sendo remetidos para análise posterior os casos que classifiquei como modo híbrido. No entanto, chamei ao meu texto um excerto de Fantasia... que me pareceu derrogar completamente todas as formas de citação previamente dilucidadas (o discurso de Tiago sintetizado pelo narrador), exemplo de práticas literárias contemporâneas renitentes ao espartilho da ortodoxia. Como consequência dessa constatação, pareceu-me essencial convocar, de entre o continuum dos fenómenos de citação que muitos linguistas atualmente preferem à rigidez da tripartição normativa tradicional, duas outras formas de RD que marcam presença no romance de MC: a ironia e o DDL. 
Ainda em 1, a leitura dos $N P P E B$, que começaram a entrar em vigor no ano letivo de 2011/2012, permitiu-me constatar que têm já em conta a dimensão plural do $\mathrm{RD}$, encarando-o como mecanismo discursivo e textual indissociável do contexto enunciativo, na senda do que é preconizado pelo programa de Português do ES, a vigorar desde 2001/2002. A consulta de gramáticas de português e de uma de PLNM revelou que, em geral, as propostas pedagógico-didáticas dos materiais de apoio disponíveis no nosso mercado editorial enfermam de uma visão congelada ou restrita, que perspetiva o RD como fenómeno meramente gramatical ou se coíbe de tirar partido pleno da afirmação da sua natureza enunciativo-discursiva. Os programas do CAPE permitem concluir que, na FLUC, os conceitos básicos relativos ao RD são adquiridos nos níveis elementar e intermédio do estudo de PLE. Mesmo considerando que nem todos os alunos (ou nenhum aluno) terão(rá) frequentado o CAPE em anos letivos transatos, tratando-se de discentes de nível C1, os conhecimentos sobre esta matéria são um pré-requisito.

Em síntese, reproduzir palavras de outros locutores é uma prática quotidiana que, fora do contexto pedagógico, académico, jornalístico e judicial, não merece habitualmente particular atenção, pois não nos detemos nas implicações linguísticas, pragmáticas, expressivas, ontológicas e éticas que lhe estão associadas.

A análise dos excertos colhidos no romance de MC comprovou o postulado atual maioritário dos teóricos do RD: se as formas canónicas (exceção feita ao DIL, que potenciou a rigidez descritiva do par DD-DI) - cuja marcação tipográfica e estrito cumprimento das regras definidas asseguram a idoneidade física e interpretativa - permitem uma tranquilizadora interpretação de quem diz o quê, a realidade da produção discursiva revela múltiplos usos, sobretudo no registo escrito e, particularmente, literário, refratários aos ditames gramaticais e que patenteiam a vitalidade expressiva das línguas. Em consequência, nem sempre é possível delimitar rigorosamente a reprodução de palavras de outrem no discurso nem identificar inequivocamente o(s) locutor(es), tornando-se aliás essa possibilidade fonte de ambiguidade polifónica de grande potencial estético, explorada criativamente sobretudo na literatura contemporânea, como o comprova 
Fantasia... Uma pista a desenvolver com alunos francófonos ou alunos falantes de Castelhano - eventualmente, de nível C2 - seria a questão da tradução do romance em francês ou castelhano. Um rápido cotejo dos exemplos portugueses de modo híbrido com as respetivas traduções em língua francesa revelou alguma diluição da subversão enunciativa. Seria interessante avaliar a intensidade polifónica de cada uma das versões do romance (portuguesa, francesa e castelhana). Não proponho idêntico trabalho para a edição croata porque não domino a língua.

Outra questão fulcral do RD é a sua inelidível ancoragem num contexto. Assumindo-se que os mecanismos de citação relevam da tríade enunciativa - «eu/tu», num espaço e num tempo determinados -, configura-se pragmaticamente incorreto e pedagogicamente infecundo estudar o RD como se estivessem em análise enunciados acrónicos e atópicos, proferidos por um emissor e dirigidos a um recetor de contornos inamovíveis. Compreende-se a inevitabilidade de estruturar regras mínimas e, sobretudo, de adequar a reflexão sobre estas matérias tão complexas às características do público-alvo. Em contexto de LE - e tomando como referência a heterogeneidade linguística dos alunos do CAPE de 2010/2011, público-alvo da minha proposta de didatização -, podem revelar-se inexequíveis estratégias de linguística comparativa, tão vantajosas no ensino-aprendizagem formal de uma LE, onde o conhecimento declarativo é instrumento fundamental. Nas aulas virtuais que concebi, esse obstáculo ficaria minimizado, porquanto conteúdos essenciais para o estudo do RD - como o complexo sistema temporal da língua portuguesa - deverão estar consolidados no nível C1 de proficiência.

Em 2., lancei mão de conceitos que relevam da análise literária. Em primeiro lugar, o de literatura como sistema modelizante secundário, depositário dinâmico de uma memória propiciadora de polifonia intertextual. Cada obra literária transporta não o mundo mas uma determinada visão do mundo - noção essencial para prevenir a tentação de decalques apressados entre o universo literário e o da realidade -, que é lida de modo único por cada leitor. A este cabe saturar, consoante a sua mundividência particular e a dimensão da sua enciclopédia, os espaços em branco que todo o texto comporta. A leitura, por conseguinte, é um 
processo irrepetível, dialético e sempre inacabado, que resulta de cada encontro entre um texto e o seu destinatário. Sendo na linguagem literária que a língua revela todas as suas potencialidades criativas, segundo o postulado coseriano, são inegáveis as virtualidades da sua entrada na sala de aula de línguas.

Em seguida, atendendo ao objetivo de encontrar em Fantasia... representações identitárias moduladas pela voz, abordei sucintamente as noções de identidade nacional, nação e nacionalismo. Apresentadas as duas principais perspetivas teóricas que estabelecem um diálogo fecundo entre si - a que destaca, na configuração de nação, a vertente cultural, étnica e orgânica e a que sobreleva os aspetos cívicos, políticos e territoriais -, foi possível concluir que o conceito de identidade nacional é, também ele, indissociável de coordenadas contextuais. Todavia, neste trabalho, a negação de uma visão essencialista desta questão e a correlativa assunção da transitoriedade dos traços de qualquer suposto perfil identitário nacional não obstam a que, em cada momento histórico, alegadas marcas caracterizadoras de um povo ou de uma comunidade sejam alvo de reflexão teórica, de criação artística ou de comentários críticos.

Seguidamente, convoquei dois conceitos do âmbito da Imagologia como instrumentos de análise do romance de MC: estereótipo (que alguns teóricos aproximam do de representação social) e mito como intertexto. O primeiro traduz uma imagem fixa sobre o Outro - alter -, que se torna fator de afirmação interna e de coesão grupal. Surge, no romance, corporizado nos ciganos e nos imigrantes de Leste. O segundo diz respeito ao diálogo intertextual que decorre da já referida memória do sistema literário. Em Fantasia..., o narrador recria, atualizando-a, uma figura literária - a Mofina Mendes vicentina -, como estratégia que complementa a configuração discursiva da voz.

Ainda em 2., dei a palavra a dois dos mais conceituados pensadores do Portugal contemporâneo - Eduardo Lourenço e José Gil -, bem como a outros vultos do universo cultural, académico, literário e mediático. A intenção foi perceber o que pensam do país e dos portugueses que o habitam, tendo sempre presente que se trata de pontos de vista historicamente marcados. Lourenço destaca a imagem dissonante - que ele 
classifica como hiperidentidade - que os seus compatriotas mantêm de si mesmos e Gil define o conceito de não-inscrição que, do seu ponto de vista, subjaz à desresponsabilização infantil que mina um precário espaço público. A perceção tendencialmente negativa que os dois intelectuais manifestam é multiplicada pelas outras vozes que convoquei para a segunda parte deste trabalho. Cumpre dizer que as procurei: tendo estabelecido a minha linha de interpretação do romance em apreço - uma representação demolidora do Portugal de 2003 -, acabei por procurar pontos de vista coincidentes com esta visão. Não foi tarefa árdua. O próprio escritor tem vindo a manifestar, ao longo da última década e meia, o seu desencanto ante o caminho que o país tem trilhado.

Na última parte do trabalho, comecei por proceder à apresentação quantitativa dos dados recolhidos no romance, fazendo em seguida a sua interpretação, o que me permitiu confirmar a hipótese de partida: em Fantasia..., registei 832 ocorrências de RD, sendo a esmagadora maioria de DD (81,3\%). Foi igualmente possível atestar que as vozes mais presentes são as das principais personagens da trama narrativa (Emanuel Elói, Bernardes, Maria das Dores e Lencastre). Levei depois a cabo o levantamento e o comentário das várias formas de RD - inclusivamente das que derrogam as regras canónicas e foram classificadas como modo bíbrido - e avaliei a sua funcionalidade na configuração da já referida tese do narrador. Procedi igualmente à análise da riqueza e exuberância expressivas da linguagem, características reconhecidas do estilo de MC e manancial de extraordinária potencialidade pedagógica. Pude assim concluir que, recorrendo aos mecanismos de citação - sobretudo ao DD e ao DIL, cujas virtualidades miméticas já foram enunciadas -, o narrador oferece o palco às suas personagens que, pela voz, se auto e heterocaracterizam, declinando os dois eixos temáticos fulcrais do romance: a verborreia que torna o país inoperante e traduz um aviltamento generalizado - nos costumes, no convívio social, na criação artística, na cultura televisiva - e o queixume reiterado e paralisante. Figuras como Maria das Dores, os dois coronéis, a claque de futebol, Nelson e os seus amigos, Sandra e Januário, entre outras, oferecem ao leitor representações de um Portugal sem espessura e caricato, onde vinga o mau gosto 
e a desonestidade, e onde os portugueses se comprazem a lamentar os potes de azeite derramados.

Finalmente, defini os pressupostos teóricos essenciais do ensino-aprendizagem de LE que orientaram a minha proposta de didatização - a produtividade da reflexão metalinguística; a articulação entre abordagem linguística e literária, cumprindo, aliás, as pistas do Quadro europeu comum de referência para as línguas; a relevância da leitura extensiva do texto literário no desenvolvimento das competências comunicativas e culturais dos alunos de LE - e apresentei as cinco etapas da unidade didática que concebi. As propostas de trabalho visaram uma reflexão sobre as características enunciativo-pragmáticas dos mecanismos de reprodução de palavras, o alargamento lexical - nomeadamente no que diz respeito aos verbos introdutores de RD - e o desenvolvimento da competência de análise literária e linguística. Sem esquecer o objetivo último - o estudo da textualização pelo RD da verbosidade e do lamento nacionais no romance -, foram também pensadas tarefas visando a promoção da leitura crítica e a discussão inter e metacultural que uma aula de LE proporciona.

A fechar o meu texto, transcrevo uma afirmação de MC alusiva à memória literária, tema caro ao escritor:

Eu não inventei isto. A literatura foi-me entregue. Tenho o dever de a devolver sem estragos. (Coutinho, 208: 29)

Ao convocar, para uma aula de PLE de nível C1, o RD e Fantasia para dois coronéis e uma piscina, o meu objetivo seria desafiar os alunos estrangeiros a descobrir como se pode configurar a heterodiscursividade enunciativa num texto literário português, na expectativa de que se deixassem seduzir pelo universo intrinsecamente polifónico de Mário de Carvalho.

A possível temeridade da empresa faz-me pensar na responsabilidade de, em hipotéticas concretizações, devolver tudo, RD e romance, "sem estragos». 


\section{Referências}

AgualuSA, J. E. (2010). Milagrário pessoal. Alfragide: D. Quixote, 13.

Amossy, Ruth e Anne H. PIERrot (2011). Stéréotypes et clichés - Langue, discours, société. Paris: Armand Colin.

ANSCOMBRE, J.-C. (2006). "Stéréotypes, gnomicité et poliphonie : la voix de son maître», in Laurent Perrin (dir.), Le sens et ses voix. Dialogisme et polyphonie en langue et en discours. Recherches linguistiques 28. Metz: Université Paul Verlaine, 349-78.

ARISTÓTEles (2008). Poética. Trad. Ana Maria Valente. Lisboa: Fundação Calouste Gulbenkian.

ARRUdA, Lígia (2008). Gramática de Português Língua Não Materna. s/l: Porto Editora, 176-7.

AUTHIER-REVUZ, J. (2004). "La représentation du discours autre: un champ multiplement hétérogène», in Juan Manuel Lopez Muñoz, Sophie Marnette et Laurence Rosier (eds.), Le discours rapporté dans tous ses états. Paris: L'Harmattan, 35-53.

AZEREDo, M. Olga, M. Isabel PINTO e M. Carmo LOPES (2009). Gramática Prática de Português. Lisboa: Lisboa Editora, 343-9.

----- (2010). Exercícios - Gramática Prática de Português. Lisboa: Lisboa Editora, 134-41.

BEBIANO, Rui (2009). "A Terceira Noite» (blogue), disponível em http://aterceiranoite.org/ (consultado em 08.12.2009).

BECHARA, Evanildo (2006). Moderna Gramática Portuguesa. $37^{\mathrm{a}}$ ed., Rio de Janeiro: Editora Lucerna, 481-3.

BESSE, M. Graciete (2004). “Há emenda para este país?" - a propósito de "Fantasia para Dois Coronéis e Uma Piscina”, de Mário de Carvalho». Latitudes 22 (Dez. 2004), 12-4, disponível em http://www.revues-plurielles.org/_uploads/pdf/17_22_3.pdf (consultado em 12.08.2011).

BIZARRO, Rosa (2008). "Linguística e Literatura: uma relação produtiva na aula de LE», in O Fascínio da Linguagem. Actas do Colóquio de Homenagem a Fernanda Irene Fonseca. Porto: Faculdade de Letras da Universidade do Porto, 355-64, disponível em http://ler. letras.up.pt/uploads/ficheiros/6716.pdf (consultado em 10.08.2011).

BOLAÑos, Aimée G. e Elena P. GonZÁLEZ (2004). «Literatura y lengua en diálogo». Glosas Didacticas. Revista Electrónica Internacional 11 (Primavera 2004), 221-9, disponível em http://www.um.es/glosasdidacticas/doc-es/20gonzalez.pdf (consultado em 12.09.2011).

Brown, H. Douglas (2001). Teaching by principles - An interactive approach to langage pedagogy. New York: Longman, 232-46, 298-333.

CABEcinhas, Rosa (2004). "Processos cognitivos, cultura e estereótipos sociais", in Actas do II Congresso Ibérico de Ciências da Comunicação, vol. IV. Covilhã: Universidade da 
Beira Interior, 539-49, disponível em http://bocc.ubi.pt/pag/cabecinhas-rosa-processos-cognitivos-cultura-estereotipos-sociais.pdf (consultado em 02.09.2011).

CAPA DA EDIÇÃo CASTELHANA de Fantasía para dos coroneles y una piscina (2011), de Mário de Carvalho, disponível em http://www.mariodecarvalho.com/estrangeiro (consultado em 25.11.2013).

CAPA DA EDIÇÃo CROATA de Fantazija Za Dva Pukvnika I Jedan Bazen (2008), de Mário de Carvalho, disponível em http://www.mariodecarvalho.com/estrangeiro (consultado em 25.11.2013).

CAPA DA EDIÇÃo FRANCESA de Fantaisie pour deux Colonels et Une Piscine (2007), de Mário de Carvalho, disponível em http://www.mariodecarvalho.com/estrangeiro (consultado em 25.11.2013).

CAPA DA EDição portuguesa de Fantasia para dois coronéis e uma piscina (2003), de Mário de Carvalho, disponível em http://www.mariodecarvalho.com/obras (consultado em 25.11.2013).

CARDOSO, Miguel E. (2010). "Os potentinhos portugueses». Expresso 1956 - Única, 24/04/2010, pp. 32-4.

----- (2011). «Desculpa lá dizer-te isto, Portugal, mas amar-te é coisa simples». PÚBLICO - P2, 10/06/2011, pp. 4-5.

Carvalho, Mário de e Clara Pinto Correia (1996). E se tivesse a bondade de me dizer porquê? Lisboa: Relógio D’Água [1 ${ }^{a}$ ed., 1986].

CARVAlHo, Mário de (1995). ¿O romance está em aberto». Jornal de Letras, Artes e Ideias 647, p. 16.

----- (1996). Era bom que trocássemos umas ideias sobre o assunto. Lisboa: Caminho.

----- (1999). O Livro Grande de Tebas Navio e Mariana. Lisboa: Caminho [1 $1^{\mathrm{a}}$ ed., 1982].

----- (2003). Fantasia para dois coronéis e uma piscina. Lisboa: Caminho.

----- (2007a). “Dá mais no Verão...”. Jornal de Letras, Artes e Ideias 960, p. 20.

----- (2007b). Fantaisie pour deux colonels et une piscine. Trad. Marie-Hélène Piwnik. Paris: Christian Bourgois Editeur.

----- (2009). "Coitado do Jack». Jornal de Letras, Artes e Ideias 1000, pp. 26-7.

----- (2010). A arte de morrer longe. Lisboa: Caminho.

----- (2011). Quando o Diabo reza. Lisboa: Tinta-da-China.

CECILIA, Juan H. (2006). "El mito como intertexto: la reescritura de los mitos en las obras literarias". Çédille. Revista de estudios franceses, $\mathrm{n}^{\circ} 2$ (Abril 2006), 58-76, disponível em http://webpages.ull.es/users/cedille/dos/cedille-dos.pdf (consultado em 02.10.2011).

CINNIRELLA, Marco (1997). "Ethnic and national stereotypes: a social identity perspective", in Barfoot, C. C. (ed.), Beyond Pug's Tour: National and Ethnic Stereotyping in Theory and Literary Practice. Amsterdam/ Atlanta: Rodopi, 37-51.

Clemente, M. (2009). Portugal e os Portugueses. Lisboa: Assírio \& Alvim, 9-17.

COELHo, Tereza (2003). "Mário de Carvalho. O livro do país patusco». PÚBLICO - Mil Folhas, 10/06/2003, pp. 4-7.

CONSELHO DA EUROPA (2002). Quadro europeu comum de referência para as línguas. Aprendizagem, ensino, avaliação. Trad. M. Joana P. do Rosário e Nuno V. Soares. Ministério da Educação/ GAERI (coord. da ed.). Porto: Asa Editores, 25, 53-8, 96-8, 103-5, 107-10, 112, 158, 160-1, 163, 167-8, 173, 191. 
COSERIU, Eugenio (1990). "Información y literatura». Conferência proferida na Universidade de Navarra, Março de 1990, disponível em www.unav.es/fcom/comunicacionysociedad/.../ pdf/20091115141715.pdf (consultado em 10.01.2010).

CosTA, João (2009). "A gramática na sala de aula: o fim das humanidades?». Palavras 36, 33-45.

COTRIM, J. P. (1996). "Mário de Carvalho, "Alguma coisa me perturba" . Ler. Livros \& Leitores 34, pp. 38-49.

COUTINHO, Isabel (2008). «Devolver a literatura sem estragos». PÚBLICO - Ípsilon, 28/03/2008, pp. 28-9.

CRUZ, Celene M. e Clémence JOUËT-PASTRÉ (2000). "O texto literário em uma classe de língua estrangeira", in Carlos Reis et al. (org.), Didáctica da Língua e da Literatura, Actas do V Congresso Internacional de Didáctica da Língua e da Literatura, vol. I, Coimbra: Almedina/ Instituto de Língua e Literatura Portuguesas da Faculdade de Letras de Coimbra, 401-6.

CUnha, Celso e Luís Filipe Lindley CinTra (1984). Nova Gramática do Português Contemporâneo. Lisboa: Sá da Costa, 451, 457-8, 629-37.

CUNHA, Luís (2006). "A identidade da nação: encenação e narrativa", in Joana Miranda e M. Isabel João. Identidades Nacionais em Debate. Lisboa: Celta, disponível em http:// bbdo.no.sapo.pt/documentos/identidade.pdf (consultado em 21.10.2011).

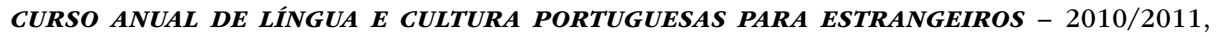
disponível em http://www.uc.pt/fluc/ensino/cpe/calcp_10_11 (consultado em 28.07.2011).

CURSO ANUAL DE PORTUGUÊS - 2010/ 2011 (níveis elementar, intermédio e superior), disponível em https://woc.uc.pt/fluc/course/coursesByDegree.do?degreeId=15 (consultado em 28.07.2011).

CURSO ANUAL DE PORTUGUêS - 2010/ 2011 (nível elementar), disponível em https://woc. uc.pt/fluc/course/infocurso.do?idcurso=538\&studiesPlanMain=false (consultado em 28.07.2011).

CURSO ANUAL DE PORTUGUês - 2010/ 2011 (nível intermédio), disponível em https://woc.uc.pt/fluc/course/infocurso.do?idcurso=547\&studiesPlanMain=false (consultado em 28.07.2011).

CURSO ANUAL DE PORTUGUês - 2010/ 2011 (nível superior), disponível em https://woc.uc.pt/fluc/course/infocurso.do?idcurso=550\&studiesPlanMain=false (consultado em 28.07.2011).

Dendale, Patrick e Danielle Coltier (2006). «Éléments de comparaison de trois théories linguistiques de la polyphonie et du dialogisme», in Laurent Perrin (dir.), Le sens et ses voix. Dialogisme et polyphonie en langue et en discours. Recherches linguistiques 28. Metz: Université Paul Verlaine, 271-99.

DICIONÁRIO TERMINOLÓGICO, disponível em http://dt.dgidc.min-edu.pt/ (consultado em julho e agosto de 2011).

DUARTE, Isabel M. (1999). "As vantagens de uma gramática do texto para o estudo do relato de discurso", in C. Mello (org.), I Jornadas Científico-Pedagógicas de Português. Instituto de Língua e Literatura Portuguesas da Faculdade de Letras da Universidade de Coimbra. Coimbra: Livraria Almedina, 113-20.

(2001). "Do saber ao ensinar: em torno dos verbos introdutores de discurso relatado", in Fernanda Irene Fonseca, Isabel Margarida Duarte e Olívia Figueiredo (orgs.), $A$ Linguística na Formação do Professor de Português. Porto: Centro de Linguística da Universidade do Porto, 125-34. 
----- (2003). O relato de discurso na ficção narrativa. Contributos para a análise da construção polifónica de Os Maias de Eça de Queirós. Lisboa: Fundação Calouste Gulbenkian/Fundação para a Ciência e a Tecnologia [1999, Tese de doutoramento, Faculdade de Letras da Universidade do Porto].

----- (2004). "A primeira vez que eu li Fantasia para dois coronéis e uma piscina, de Mário de Carvalho». Primeir@ Prova - Revista Electrónica de Linguas e Literaturas Modernas - Departamento de Estudos Portugueses e Estudos Românicos da FLUP, $n^{\circ} 0$ (Abril 2004), disponível em http://repositorio-aberto.up.pt/bitstream/10216/23649/2/ isabelduarteprimeiraprova000096437.pdf (consultado em 03.08.2011).

DUARTE, Luís R. (2010). "Mário de Carvalho. Um romance do tempo». Jornal de Letras, Artes e Ideias 1032, pp. 10-3.

ECO, Umberto (1993). Leitura do texto literário - lector in fabula. Lisboa: Editorial Presença, 53-70.

FARIA, L. M. (2003). "Mário de Carvalho. Muitas palavras, pouca conversa». EXPRESSO 1621 - Actual, 22/11/2003, pp. 46-7.

FIGUEIREDO, Olívia M. e Eunice B. de FIGUEIREDO (2009). Itinerário gramatical. Gramática do Discurso e Gramática da Língua. Porto: Porto Editora, 63-6.

FILlOLA, A. Mendoza (2004). "Los materiales literarios en la enseñanza de ELE: funciones y proyección comunicativa”. Red ELE - Revista Electrónica de Didáctica/Español Lengua Extranjera, $\mathrm{n}^{\circ} 1$ (2004), 1-49, disponível em http://www.mec.es/redele/revista1/pfds1/ mendoza.pdf (consultado em 23.12.2007).

FONSECA, F. I. (1994). Gramática e Pragmática - Estudos de Linguística Geral e de Linguística Aplicada ao Ensino do Português. Porto: Porto Editora, 9-103, 117-82.

----- (2000). "Da inseparabilidade entre o ensino da língua e da literatura», in Carlos Reis et al. (org.), Didáctica da Língua e da Literatura, Actas do V Congresso Internacional de Didáctica da Língua e da Literatura, vol. I, Coimbra: Almedina/ Instituto de Língua e Literatura Portuguesas da Faculdade de Letras de Coimbra, 37-45.

FONSECA, J. (1991). "Heterogeneidade na Língua e no Discurso". Revista da Faculdade de Letras da Universidade do Porto. Série "Línguas e Literaturas", Vol. VIII. Porto: Universidade do Porto. Faculdade de Letras, 261-304, disponível em http://ler.letras.up.pt/uploads/ ficheiros/2626.pdf (consultado em 22.11.2009).

GAlisson, R. e D. Coste (1983). Dicionário de Didáctica das Línguas. Coimbra: Almedina, 134-5, 442-5.

GAONAC'H, Daniel (2005). "La lecture en langue étrangère : un tour d'horizon d'une problématique de psychologie cognitive». Acquisition et Interaction en Langue Étrangère, disponível em http://aile.revues.org/document970.html (consultado em 02.02.2008).

GIL, J. (2005). Portugal, hoje. O medo de existir. Lisboa: Relógio D’Água. (2009). Em busca da identidade - o desnorte. Lisboa: Relógio D’Água.

GRABE, William (2002). "Dilemmas for the development of second language reading abilities", in Willy A. Renandya e J. Richard (eds.), Methodology in Language Teaching: An Anthology of Current Practice. Cambridge: University Press, 276-86.

GRANDE PRÉMIO DE LITERATURA ITF/ DST, disponível em http://www.dstsgps.com/upload/ docs/GPL/HistorialGPL10.pdf (consultado em 29.07.2011).

GRASSIN, J.-M. (s/d). "Image», in Robert Escarpit (org.), Dictionnaire International des Termes Littéraires, disponível em http://www.ditl.info/arttest/art2241.php (consultado em 13.07.2008). 
GRELLET, Françoise (2001). Developing Reading Skills. Cambridge: University Press, 2-25 [1 ${ }^{\mathrm{a}}$ ed., 1981].

GUERREIRO, A. (2003). "Quase uma comédia». EXPRESSO 1621 - Actual, 22/11/2003, pp. 46-7.

HORÁCIO (2001). Arte Poética. Trad. R. M. Rosado Fernandes. Mem Martins: Editorial Inquérito.

JANZEN, Joy (2002). «Teaching strategic reading», in Willy A. Renandya e J. Richard (eds.). Methodology in Language Teaching: An Anthology of Current Practice. Cambridge: University Press, 287-94.

JORGE, Lídia (2009). Contrato sentimental, Lisboa: Sextante Editora.

KUYUMCUYAN, Annie (2006). "Les narrations comme mentions " - Polyphonies et narration", in Laurent Perrin (dir.), Le sens et ses voix. Dialogisme et polyphonie en langue et en discours. Recherches linguistiques 28. Metz: Université Paul Verlaine, 143-64.

LEERSSEN, Joep (1991). "Mimesis and Stereotype», in J. Leerssen e Spiering (eds.), Yearbook of European Studies 4, Amsterdam: Rodopi, 165-75.

LEIRIA, I. (2004). "Português língua segunda e língua estrangeira : investigação e ensino", in Idiomático. Revista Digital de Didáctica de PLNM, $\mathrm{n}^{\circ} 3$, Centro Virtual Camões (2004), disponível em http://crc.instituto-camoes.pt/idiomatico/03/01.html (consultado em 22.07.2011).

LIMA, J. Pinto de (2007). Pragmática linguística. Lisboa: Caminho, 57-65.

LOPES, A. C. Macário (2006). "O "conhecimento sobre a língua" no ensino do Português", in Inês Duarte e Paula Morão (org.), Ensino do Português para o século XXI. Departamento de Linguística Geral e Românica e Departamento de Literaturas Românicas/FLUL. Lisboa: Edições Colibri, 75-81.

LOPES, Óscar (1971). Gramática simbólica do Português (um esboço). Lisboa: Centro de Investigação Pedagógica, 256-67.

LOURENÇO, Eduardo (2000). "O imaginário português neste fim de século". Jornal de Letras, Artes e Ideias 763 , pp. 20-3.

(2005). O Labirinto da Saudade. Psicanálise mítica do destino português. Lisboa: Gradiva, 11-79, 127-35, 173-80 [1 $1^{\mathrm{a}}$ ed., 1978].

Luís, Sara B. (2003). "Que raio de país é este?». Visão 561, 04/12/2003, pp. 174-8.

MARQUES, C. Vaz (2010). "Mário de Carvalho. "A literatura nunca foi um fenómeno democrático". Ler 91, pp. 32-7, 86-8.

MARTINS, C. Oliveira (2004). "Mário de Carvalho. Pátria lusitana. O retrato, a ironia e o desencanto". Os Meus Livros 19, pp. 38-43.

MARTINS, C. Oliveira (2007). "Mário de Carvalho e o retrato melancólico de um país: ironia, paródia e desencanto". Comunicação apresentada na Conferência Internacional Diálogos com a Lusofonia: um Encontro na Polónia. Colóquio Comemorativo dos 30 anos da Secção Luso-Brasileira do Instituto de Estudos Ibéricos e Ibero-Americanos da Universidade de Varsóvia, Polónia, 10-11 de Dezembro, 255-72, disponível em http://iberystyka-uw. home.pl/pdf/Dialogos-Lusofonia/Coloquio_ISIiI-UW_17_MARTINS-J.Candido-OLIVEIRA_ Mario-de-Carvalho-e-o-retrato-melancolico-de-um-pais.pdf (consultado em 17.08.2011).

MARTINS, M. João (2003). "Mário de Carvalho: crónica do aturdimento". Jornal de Letras, Artes e Ideias 864, pp. 10-2.

MatToso, J. (1994). "A invenção de Portugal», in História de Portugal, Vol. 6, José Mattoso (dir.), Lisboa: Editorial Estampa, 565-95. 
MEDINA, João (2006). Portuguesismo(s) - (Acerca da Identidade Nacional). Lisboa: Centro de História da Universidade de Lisboa - Faculdade de Letras da Universidade de Lisboa, 35-84, 203-15, 301-6.

MENDES, A. M. Gonçalves (2005). «Trimalquião, os coronéis e a piscina: retrato impiedoso de um país em crise». Ágora. Estudos Clássicos em Debate 7 (2005), 129-50, disponível em http://www2.dlc.ua.pt/classicos/Trimalquiao.pdf (consultado em 02.08.2011).

MEXIA, Pedro (s.d.), in Nova cultura, Janeiro de 2004, disponível em http://www.novacultura. de/0401carvalho.html (consultado em 07.03.2009).

MóNICA, Maria Filomena (2009). Nós, os portugueses. Vila Nova de Famalicão: Quasi, 88-90.

MOURA, J.-M. (1998). L'Europe littéraire et l'ailleurs. Paris: Presses Universitaires de France, 35-55.

NOVOS PROGRAMAS DE PORTUGUÊS DO ENSINO BÁSICO, disponíveis em http://sitio.dgidc. min-edu.pt/linguaportuguesa/Documents/Programas\%20de\%20Português\%20homologado.pdf (consultado em 01.08.2011).

P.E.N. CLUbE PORTUGUÊS - Prémios Literários do P.E.N. Clube Português - Poesia, Ensaio, Ficção e Primeira Obra, disponível em http://penclube.no.sapo.pt/pen_portugues/premios/ premiados_ficcao.htm (consultado em 29.07.2011).

PAlouro, Ricardo (2009). "Entrevista a Mário de Carvalho - Sob o peso da palavra». A.23 On line (Jan. 2009), disponível em http://www.a23online.com/2009/08/10/ entrevista-a-mario-de-carvalho-sob-o-peso-da-palavra/ (consultado em 07.03.2009).

PAPANÇA, António de Macedo, disponível em http://forumpatria.com/cultura-e-patrimonio-portugues/ antonio-de-macedo-papanca-conde-de-monsaraz/ (consultado em 07.10.2011).

PEREIRA, J. Pacheco, Abrupto (blogue), disponível em http://abrupto.blogspot.com/ search?q=analogia (consultado em 17.08.2011).

PERRIN, Laurent (2006). "Introduction», in Laurent Perrin (dir.), Le sens et ses voix. Dialogisme et polyphonie en langue et en discours. Recherches linguistiques 28. Metz: Université Paul Verlaine, 5-17.

PEYTARD, Jean (1995). Mikhaïl Bakhtine. Dialogisme et analyse du discours. Paris: Bertrand-Lacoste.

PIÇARRA, Sandra (2008). Estratégias Paródicas e o Pacto de Leitura na Obra Fantasia para Dois Coronéis e uma Piscina de Mário de Carvalho. Universidade de Évora, disponível em http://www.ensino.uevora.pt/mclc/Tese\%20Sandra\%20Picarra.pdf, (consultado em 08.10.2011) [Dissertação de Mestrado em Literatura Portuguesa].

PINA, Manuel A. (2008). "Um país ciclotímico". Jornal de Notícias, 27/02/2008, disponível em http://bracosaoalto.blogspot.com/2008/02/imprensa-jn-porto.html (consultado em 27.02.2008).

----- (2009). «Más companhias». Jornal de Notícias, 07/08/2009, disponível em http://jn.sapo. pt/Opiniao/default.aspx?opiniao=Manuel\%20Ant\%F3nio\%20Pina (consultado em 08.08.2009).

PlATÃo (2007). A República. Trad. Maria Helena da Rocha Pereira. Lisboa: Fundação Calouste Gulbenkian, 392d-398e, 595a-621d.

PROGRAMA DE LÍNGUA PORTUGUESA Do $2^{\circ}$ CiClo, disponível em http://sitio.dgidc.minedu. pt/recursos/Lists/Repositrio\%20Recursos2/Attachments/155/programa_LPortuguesa_2-Ciclo02.pdf (consultado em 01.08.2011).

PROGRAMA DE LÍNGUA PORTUGUESA Do $3^{\circ}$ CICLO, disponível em http://sitio.dgidc.minedu. pt/recursos/Lists/Repositrio\%20Recursos2/Attachments/171/programa_LPortuguesa_3Ciclo.pdf (consultado em 01.08.2011). 
PROGRAMA DE PORTUGUÊS $\left(10^{\circ}, 11^{\circ}\right.$ e $12^{\circ}$ anos dos Cursos Científico-Humanísticos e Cursos Tecnológicos), disponível em http://sitio.dgidc.min-edu.pt/recursos/Lists/Repositrio\%20 Recursos2/Attachments/280/portugues_10_11_12.pdf (consultado em 01.08.2011).

PUREN, Christian (2006). "Explication de textes et perspective actionnelle: la littérature entre le dire scolaire et le faire social". Association des professeurs de langues vivantes, disponível em http://www.aplv-languesmodernes.org/spip.php?article389 (consultado em 20.08.2010).

----- (2010). "Compétence culturelle et nouvelle perspective actionnelle», in Les (nouveaux?) enjeux de FLE: implication, interaction et motivation. 5ème Rencontre Difusión-FLE. 26 e 27 de Novembro, Instituto Francês de Barcelona, disponível em http://rencontre-fle. com/ (consultado em 04.12.2010) [Conferência áudio].

RABATEL, Alain (2004). "Les verbes de perception, entre point de vue représenté et discours représentés", in Juan Manuel Lopez Muñoz, Sophie Marnette et Laurence Rosier (eds.), Le discours rapporté dans tous ses états. Paris: L'Harmattan, 81-93.

(2006). "Genette, les voix du texte littéraire et les phénomènes d'hétérogénéité discursive", in Laurent Perrin (dir.), Le sens et ses voix. Dialogisme et polyphonie en langue et en discours. Recherches linguistiques 28. Metz: Université Paul Verlaine, 165-88.

REIS, Carlos e A. C. M. LOPES (2002). Dicionário de Narratologia. Coimbra: Almedina, 39-42, 100-5, 122-4, 207-10, 217-9, 237-9, 257-9, 314-22, 329-35.

RENANDYA, W. e G. M. JACOBS (2002). "Extensive reading: why aren't we all doing it?", in Willy A. Renandya e J. Richard (eds.). Methodology in Language Teaching: An Anthology of Current Practice. Cambridge: University Press, 295-302.

REYES, Graciela (1984). Polifonía textual. La citación en el relato literario. Madrid: Editorial Gredos.

(1993). Los procedimientos de cita: estilo directo y estilo indirecto. Madrid: Arco/ Libros.

(1994). Los procedimientos de cita: citas encubiertas y ecos. Madrid: Arco Libros.

(1995). El abecé de la pragmática. Madrid: Arco Libros, 38-52.

RIBEIRO, Rita (2004). "A nação na Europa - breve discussão sobre identidade nacional, nacionalismo e supranacionalismo". Cadernos do Noroeste. Série Sociologia (2004). Instituto de Ciências Sociais da Universidade do Minho, 85-96, disponível em http:// repositorium.sdum.uminho.pt/handle/1822/5646?mode=full\&submit_simple=Mostrar+registo+em +formato+completo (consultado em 07.08.2011).

RIGNEY, Ann (2007). "Representation", in Manfred Beller and Joep Leerssen (eds.), Imagology: the cultural construction and literary representation of national characters: a critical survey. New York: Rodopi, 405-7.

RODRIGUES, M. Teresa (2008). «Eduardo Lourenço, hermeneuta do imaginário português». Comunicação apresentada no Congresso Internacional - Eduardo Lourenço 85 anos. Lisboa, Fundação Calouste Gulbenkian. Lisboa, 6 e 7 de Outubro de 2008, 1-16, disponível em http://www.eduardolourenco.com/6_oradores/oradores_PDF/Maria_Teresa_Rodrigues.pdf (consultado em 05.08.2011).

ROSIER, Laurence (1999). Le discours rapporté. Histoire, théories, pratiques. Bruxelles: Duculot.

----- (2006). "Polyphonie: les "dessous” d'une métaphore ?», in Laurent Perrin (dir.), Le sens et ses voix. Dialogisme et polyphonie en langue et en discours. Recherches linguistiques 28. Metz: Université Paul Verlaine, 189-211.

SÁ, Jorge de e Luís RETo (2002). Vox populi . O estado da opinião em Portugal. Lisboa: Bertrand, 175-203. 
SANTos, Rosana B. dos (2009). Aspectos da Herança Clássica em Mário de Carvalho. Faculdade de Letras da UFMG, Belo Horizonte, 149-201, 264-8, disponível em http:// www.bibliotecadigital.ufmg.br/dspace/handle/1843/ECAP-7QUJ7S (consultado em 16.08.2011) [Tese de Doutoramento].

SEIXO, M. Alzira (2004). "O Alentejo do nosso contentamento». Visão 570, 05/02/2004, p. 112.

SEQUEIRA, Rosa (2003). O poder e o desejo. O ensino da literatura a estrangeiros na universidade. Lisboa: Ministério da Educação, 55-82, 187-238, 261-5.

SILVA, João Céu e (2010). "A tartaruga como protagonista". Diário de Notícias - Notícias Sábado 224 - Suplemento IN', 24/04/2010, pp. 54-5.

SILVA, V. M. Aguiar e (1983). Teoria da Literatura. Coimbra: Livraria Almedina, 43-4, 90-107, 112-3, 144-50, 171-3, 258-65, 300-29.

----- (2010). As Humanidades, os Estudos Culturais, o ensino da Literatura e a política da língua portuguesa. Coimbra: Almedina, 147-169, 181-90, 227-32.

SIMÕES, M. João (2006). "Jogo ficcional : personagens desbordantes em Mário de Carvalho", in Carlos Reis (coord.), Figuras da ficção. Coimbra : Centro de Literatura Portuguesa/ Faculdade de Letras, 79-91.

SMITH, Anthony (1992). "National Identity and the Idea of European Unity", in International Affairs (Royal Institute of International Affairs 1944), Blackwell Publishing on behalf of the Royal Institute of International Affairs, vol. 68, $\mathrm{n}^{\circ}$ 1, 55-76, disponível em http:// www.clas.ufl.edu/users/ckostopo/GreekIdentity/2620461.pdf (consultado em 07.08.2011).

SOUSA, Teresa de (2010). "Eduardo Lourenço - Portugal não é um país fácil de governar.». PÚBLICO - P2, 05/04/2010, pp. 4-6.

TAKAHASHI, Neide (2008). Textos literários no ensino de Português-Língua Estrangeira (PLE) no Brasil. São Paulo: Universidade de São Paulo, 18-82, disponível em www.teses. usp.br/.../DISSERTACAO_NEIDE_TOMIKO_TAKAHAS (consultado em 03.08.2011) [Dissertação de Mestrado].

TAVARES, João M. (2009). "Por isso é que isto está como está». Jornal i, 01/08/2009, disponível em http://www.ionline.pt/conteudo/16182-por-isso-e-que-isto-esta-como-esta (consultado em 01.08.2009).

TIERNEY, Jonh (2004). "2004: In a Word; ADULTESCENT". New York Times, 26/12/2004, disponível em http://query.nytimes.com/gst/fullpage.html?res=9D04EEDD1E30F935A15751C1 A9629C8B63 (consultado em 08.10.2011).

TORGA, Miguel (2007). Portugal. Lisboa: Dom Quixote, 97-9 [1 a ed., 1950].

VASCONCELOS, Joana (2010). «Portugal a Banhos», disponível em http://www.joanavasconcelos. com/ (consultado em 15.01.2011).

VENÂNCIO, Fernando (1995). "Mário de Carvalho. "Não há crítica literária em Portugal”». Jornal de Letras, Artes e Ideias 647, p. 17.

VICENTE, Gil (1984). Compilaçam de todalas obras de Gil Vicente. Vol. I, Lisboa: Imprensa Nacional/ Casa da Moeda, 102-24.

VIEGAS, F. José (2003). "Retrato da comédia portuguesa». Grande Reportagem 155, p. 68.

VIEIRA, Agripina C. (2004). "Realidade tornada ficção». Jornal de Letras, Artes e Ideias 874, pp. 22-3.

VIEIRA, Alice (2009). "Depois logo se vê». Jornal de Notícias, 28/03/2009, disponível em http://jn.sapo.pt/Opiniao/default.aspx?opiniao=Alice\%20Vieira (consultado em 29.03.2009). 
VINCENT, Diane (2006). "Polyphonie et interaction", in Laurent Perrin (dir.), Le sens et ses voix. Dialogisme et polyphonie en langue et en discours. Recherches linguistiques 28. Metz: Université Paul Verlaine, 127-142.

VION, Robert (2006). "Modalisation, Dialogisme et Polyphonie», in Laurent Perrin (dir.), Le sens et ses voix. Dialogisme et polyphonie en langue et en discours. Recherches linguistiques 28. Metz: Université Paul Verlaine, 105-125.

ZINK, Rui (2009). "Manual para chocar Portugueses Felizes», disponível em http://ruizink. com/ (blogue) (consultado em 04.07.2009). 
(Página deixada propositadamente em branco) 
ANEXOS 
(Página deixada propositadamente em branco) 
ANEXO 1 - TEIA DE PERSONAGENS - FANTASIA PARA DOIS CORONÉis E UMA PISCINA, DE MÁrio DE CARVALHO ( 20003$)^{298}$

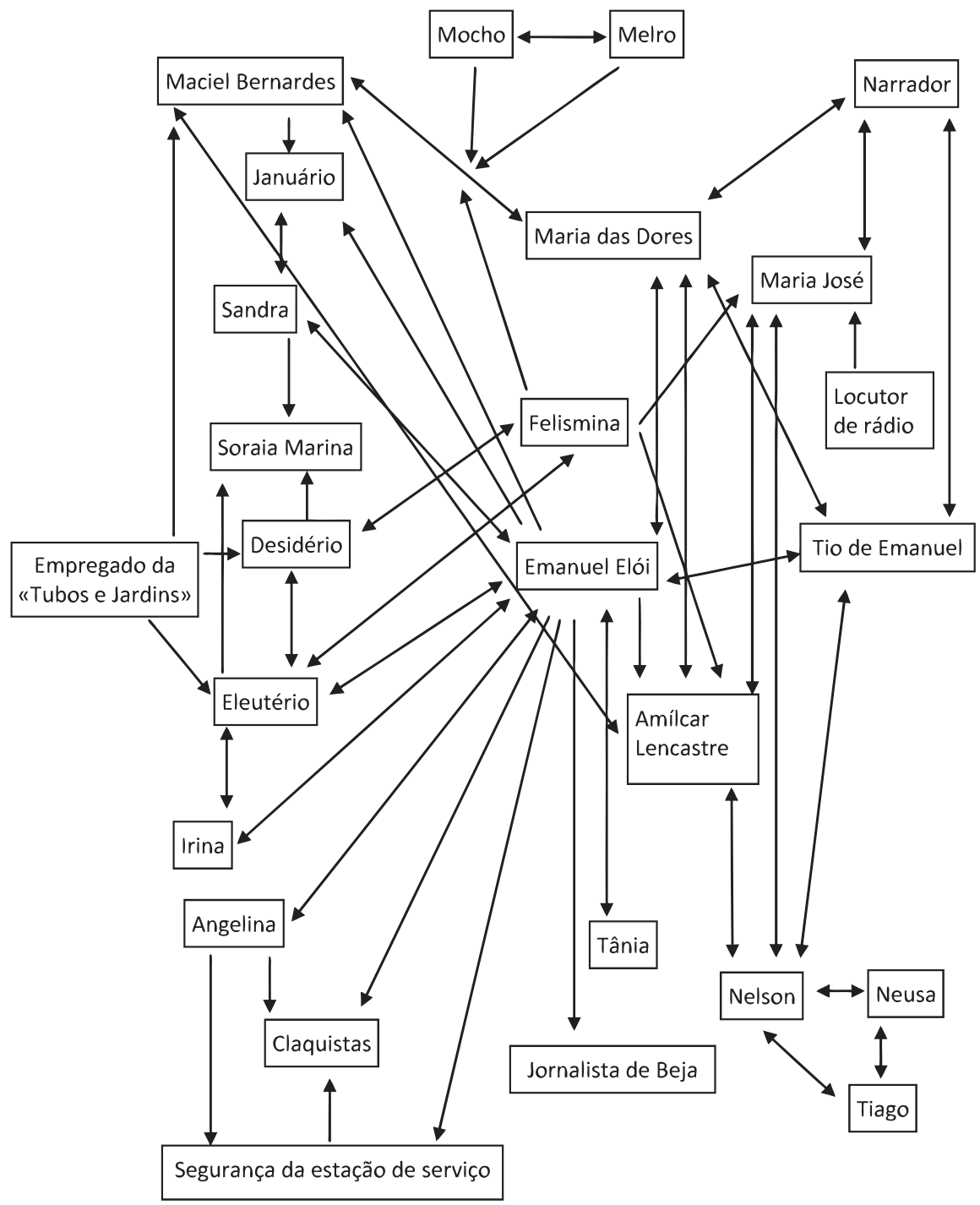

298 As setas simples indicam o sentido principal da relação entre as personagens; as setas duplas assinalam a reciprocidade. 


\section{ANEXO 2 - O RELATO DE DISCURSO NOS PRO- \\ GRAMAS OFICIAIS DE LínguA PORTUGUESA/ \\ PORTUGUÊ S}

PROGRAMAS DE 1991299

\section{$\mathbf{2}^{\circ}$ Ciclo}

\begin{tabular}{|c|c|c|}
\hline $\begin{array}{l}\text { Ano de escola- } \\
\text { ridade }\end{array}$ & $\begin{array}{l}\text { Domínio: Funcionamento da Língua } \\
\text { Conteúdo programático }\end{array}$ & Página \\
\hline $5^{\circ}$ & "Identificar o discurso directo" & 41 \\
\hline $6^{\circ}$ & $\begin{array}{l}\text { "Identificar diferentes modos de representação do discurso (discur- } \\
\text { so directo e indirecto)» }\end{array}$ & 41 \\
\hline
\end{tabular}

\section{$3^{\circ}$ Ciclo}

\begin{tabular}{|c|c|c|}
\hline $\begin{array}{l}\text { Ano de escola- } \\
\text { ridade }\end{array}$ & $\begin{array}{c}\text { Domínio: Funcionamento da Língua } \\
\text { Conteúdo programático }\end{array}$ & Página \\
\hline $7^{\circ}$ & $\begin{array}{l}\text { "Identificar e utilizar diferentes modos de representação do discurso } \\
\text { (directo e indirecto): transformar discurso directo em indirecto e } \\
\text { vice-versa." }\end{array}$ & 49 \\
\hline $8^{\circ}$ & $\begin{array}{l}\text { "Identificar e utilizar diferentes modos de representação do discurso } \\
\text { (citação).» }\end{array}$ & 49 \\
\hline $9^{\circ}$ & $\begin{array}{l}\text { "Identificar e utilizar diferentes modos de representação do discurso } \\
\text { (indirecto livre).» }\end{array}$ & 49 \\
\hline
\end{tabular}

299 Programas do $2^{\circ}$ e $3^{\circ}$ Ciclos do Ensino Básico, homologados em 1991, pelo Ministério da Educação, ainda em vigor no ano letivo de 2010/2011.

Programa de Língua Portuguesa do $2^{\circ}$ Ciclo:

http://sitio.dgidc.minedu.pt/recursos/Lists/Repositrio\%20Recursos2/Attachments/155/programa_ LPortuguesa_2-Ciclo02.pdf.

Programa de Língua Portuguesa do $3^{\circ}$ Ciclo:

http://sitio.dgidc.minedu.pt/recursos/Lists/Repositrio\%20Recursos2/Attachments/171/programa LPortuguesa_3Ciclo.pdf. 
PROGRAMAS DE 2009300

\section{$2^{\circ}$ Ciclo}

\begin{tabular}{|c|c|c|c|}
\hline Competência & Descritor de desempenho & Conteúdo programático & Página \\
\hline $\begin{array}{l}\text { LEITURA } \\
\text { «Ler para apreciar } \\
\text { textos variados» }\end{array}$ & $\begin{array}{l}\text { "Distinguir diferentes "vozes" (pers- } \\
\text { pectivas) no interior de um mesmo } \\
\text { texto e valores (socioculturais, éti- } \\
\text { cos, estéticos ou outros) que veicu- } \\
\text { lam.» }\end{array}$ & «Polifonia» & 86 \\
\hline $\begin{array}{l}\text { CONHECIMENTO } \\
\text { EXPLÍCITO DA } \\
\text { LÍNGUA } \\
\text { «Plano discursivo e } \\
\text { textual» }\end{array}$ & $\begin{array}{l}\text { «istinguir modos de reprodução } \\
\text { do discurso no discurso, quer no } \\
\text { modo oral quer no modo escrito } \\
\text { (3).» }\end{array}$ & $\begin{array}{l}\text { «Discurso directo/indirecto } \\
\text { Discurso directo livre; dis- } \\
\text { curso indirecto livre»301 } \\
\text { Nota: } \\
\text { "(3) Transformação do dis- } \\
\text { curso directo em discurso } \\
\text { indirecto e vice-versa. Expli- } \\
\text { citação dos indicadores grá- } \\
\text { ficos usados na escrita para } \\
\text { a representação do discurso } \\
\text { próprio ou de outrem (cita- } \\
\text { do e relatado).» }\end{array}$ & 98 \\
\hline
\end{tabular}

300 Os Novos Programas de Português do Ensino Básico - NPPEB -, que começaram a entrar em vigor no ano letivo de 2011/2012, estão disponíveis no seguinte endereço:

http://sitio.dgidc.min-edu.pt/linguaportuguesa/Documents/Programas\%20de\%20Português\%20 homologado.pdf.

301 Estas duas últimas referências destinam-se unicamente aos docentes. 


\section{$3^{\circ}$ Ciclo}

\begin{tabular}{|c|c|c|c|}
\hline Competência & Descritor de desempenho & Conteúdo programático & Página \\
\hline $\begin{array}{l}\text { PARTICIPAR EM SITU- } \\
\text { AÇÕES DE INTERAC- } \\
\text { ÇÃO ORAL }\end{array}$ & $\begin{array}{l}\text { «Explorar os processos de } \\
\text { construção do diálogo e o } \\
\text { modo como se pode agir atra- } \\
\text { vés da fala (5) (6).» }\end{array}$ & $\begin{array}{l}\text { "Diálogo; dialogismo» } 302 \\
\text { "(5) P. ex., relações de po- } \\
\text { der e processos de mani- } \\
\text { pulação que se estabele- } \\
\text { cem através da fala. } \\
\text { (6) P. ex., participação em } \\
\text { dramatizações, simula- } \\
\text { ções, improvisações." }\end{array}$ & 122 \\
\hline $\begin{array}{l}\text { ESCREVER PARA CONS- } \\
\text { TRUIR E EXPRESSAR } \\
\text { CONHECIMENTO(S) }\end{array}$ & $\begin{array}{l}\text { «Seleccionar tipos e formatos } \\
\text { de textos adequados a inten- } \\
\text { cionalidades e contextos es- } \\
\text { pecíficos (5): } \\
\text { - narrativos (reais ou ficcionais; } \\
\text { [...] } \\
\text { - dialogais e dramáticos; } \\
{[\ldots], 303}\end{array}$ & $\begin{array}{l}\text { "Reprodução do discurso } \\
\text { no discurso" }\end{array}$ & 126 \\
\hline $\begin{array}{l}\text { ESCREVER EM TERMOS } \\
\text { PESSOAIS E CRIATI- } \\
\text { VOS }\end{array}$ & $\begin{array}{l}\text { "Explorar diferentes vozes e } \\
\text { registos para comunicar vi- } \\
\text { vências, emoções, conheci- } \\
\text { mentos, pontos de vista, uni- } \\
\text { versos no plano do imaginá- } \\
\text { rio (1)." }\end{array}$ & $\begin{array}{l}\text { Texto/ textualidade } \\
\text { Polifonia»304 } \\
\text { "Intertexto/ Intertextua- } \\
\text { lidade» } \\
\text { Nota: } \\
\text { "(1) P. ex.: diário, auto- } \\
\text { biografia, memória, carta, } \\
\text { retrato, auto-retrato, co- } \\
\text { mentário crítico, narrati- } \\
\text { vas imaginárias, poemas.» }\end{array}$ & 128 \\
\hline $\begin{array}{l}\text { PLANO DISCURSIVO } \\
\text { E TEXTUAL }\end{array}$ & $\begin{array}{l}\text { "Distinguir modos de repro- } \\
\text { dução do discurso no discur- } \\
\text { so e sua produtividade." }\end{array}$ & $\begin{array}{l}\text { "Discurso indirecto livre } \\
\text { (4) } \\
\text { Deixis (pessoal, temporal, } \\
\text { espacial); anáfora } 305 \\
\text { Nota: } \\
\text { "Exploração da fusão de } \\
\text { fronteiras entre a voz do } \\
\text { enunciador-relator e do } \\
\text { primeiro enunciador e dos } \\
\text { procedimentos sintácticos } \\
\text { que lhe estão associados." }\end{array}$ & 134 \\
\hline
\end{tabular}

302 Esta última referência destina-se unicamente aos docentes.

303 De entre outros igualmente relevantes.

304 Estas duas últimas referências destinam-se unicamente aos docentes.

305 Os conceitos relativos aos deíticos e aos anafóricos destinam-se unicamente aos docentes. 
Ensino Secundário 306

\begin{tabular}{|c|c|c|}
\hline Ano de escolaridade & $\begin{array}{c}\text { Domínio: Funcionamento da Língua } \\
\text { Conteúdo programático }\end{array}$ & Página \\
\hline $10^{\circ}$ & $\begin{array}{l}\text { «Pragmática e Linguística textual } \\
{[\ldots]} \\
\text { - Reprodução do discurso no discurso } \\
\text {. modos de relato do discurso } \\
\text {. verbos introdutores de relato do discurso» }\end{array}$ & 13 \\
\hline $\mathbf{1 1}^{\mathbf{0}}$ & Não há referência a este conteúdo. & - \\
\hline $\mathbf{1 2}^{\mathbf{o}}$ & «- Consolidação dos conteúdos dos $10^{\circ}$ e $11^{\circ}$ anos» & 15 \\
\hline
\end{tabular}

306 O programa de Português para os $10^{\circ}, 11^{\circ}$ e $12^{\circ}$ anos dos Cursos Científico-Humanísticos e Cursos Tecnológicos, homologado em 2001 ( $10^{\circ}$ ano) e 2002 ( $11^{\circ}$ e $12^{\circ}$ anos), está disponível em http://sitio.dgidc.min-edu.pt/recursos/Lists/Repositrio\%20Recursos2/Attachments/280/portugues_10_11_12.pdf. 


\section{ANEXO 3 - O RELATO DE DISCURSO NOS PROGRAMAS DO CURSOANUAL DE PORTUGUES PARA ESTRANGEIROS( 2010 O}

Nível Elementar 307

\begin{tabular}{|l|l|l|l|}
\hline \multicolumn{2}{|c|}{$1^{\text {' Semestre }}$} & \multicolumn{2}{|c|}{$\mathbf{2}^{\circ}$ Semestre } \\
\hline A1 & $\begin{array}{l}\text { O RD não consta do programa da uni- } \\
\text { dade curricular. }\end{array}$ & A2 & $\begin{array}{l}\text { «. Conteúdos gramaticais } \\
\text { [... Sintaxe [...] } \\
\text { Discurso indirecto } \\
\text { (de acordo com tempos e modos ver- } \\
\text { bais estudados)». }\end{array}$ \\
\hline A2 & $\begin{array}{l}\text { «Discurso indirecto (de acordo com } \\
\text { tempos e modos verbais estudados)». }\end{array}$ & A2+ & $\begin{array}{l}\text { O RD não consta do programa da uni- } \\
\text { dade curricular. }\end{array}$ \\
\hline A2+ & $\begin{array}{l}\text { O RD não consta do programa da uni- } \\
\text { dade curricular. }\end{array}$ & B1 & $\begin{array}{l}\text { O RD não consta do programa da uni- } \\
\text { dade curricular. }\end{array}$ \\
\hline
\end{tabular}

Nível Intermédio 308

\begin{tabular}{|c|c|c|c|}
\hline \multicolumn{2}{|r|}{$1^{\circ}$ Semestre } & \multicolumn{2}{|r|}{$2^{\circ}$ Semestre } \\
\hline B1 & $\begin{array}{l}\text { "B. Conteúdos gramaticais: }[\ldots] \\
\text { 5. Discurso indirecto: particularidades } \\
\text { desta forma de reprodução do discurso } \\
\text { no discurso; sua relação com o discurso } \\
\text { directo.» }\end{array}$ & B1+ & $\begin{array}{l}\text { "B. Conteúdos gramaticais: } \\
\text { [...] } \\
\text { 5. Discurso directo e indirecto." }\end{array}$ \\
\hline B2 & $\begin{array}{l}\text { "2. Conteúdos gramaticais: } \\
\text { [...] } \\
\text { b) Sintaxe: } \\
\text { Subordinação } \\
\text { [...] } \\
\text {. discurso directo vs. discurso indirecto } \\
\text { (consolidação)». }\end{array}$ & B2+ & $\begin{array}{l}\text { "2. Conteúdos gramaticais: } \\
{[\ldots]} \\
\text { Sintaxe: } \\
{[\ldots]} \\
\text {. discurso directo vs. discurso indirecto } \\
\text { (consolidação)". }\end{array}$ \\
\hline
\end{tabular}

307 Programas disponíveis na woc: https://woc.uc.pt/fluc/course/infocurso.do?idcurso=538\&studiesPlan Main=false.

308 Programas disponíveis na woc: https://woc.uc.pt/fluc/course/infocurso.do?idcurso=547\&studiesPlan Main=false. 
Nível Superior ${ }^{309}$

\begin{tabular}{|l|l|l|l|}
\hline \multicolumn{2}{|c|}{$1^{\circ}$ Semestre } & \multicolumn{2}{c|}{$2^{\circ}$ Semestre } \\
\hline C1 & $\begin{array}{l}\text { O RD não consta do programa da unidade } \\
\text { curricular. }\end{array}$ & C1+ & $\begin{array}{l}\text { O RD não consta do programa da unida- } \\
\text { de curricular. }\end{array}$ \\
\hline
\end{tabular}

309 Programas disponíveis na woc: https://woc.uc.pt/fluc/course/infocurso.do?idcurso $=550 \&$ studiesPlanMain $=$ false . 
ANEXO 4 - O RELATO DE DISCURSO EM FANTASIA PARA Dois CORONÉIS E UMA PISCINA, DE MÁrio DE CARVALHO

TABELA 1 - TIPO DE RELATO DE DISCURSO

\begin{tabular}{|l|c|c|}
\hline \multicolumn{1}{|c|}{ Tipo de RD } & $\begin{array}{c}\text { Número de ocorrências } \\
\text { (em 832 registos) }\end{array}$ & $\begin{array}{c}\text { \% } \\
\text { (na totalidade do romance) }\end{array}$ \\
\hline DD & 676 & $81,3 \%$ \\
\hline DIL & 54 & $6,5 \%$ \\
\hline $\begin{array}{l}\text { Reprodução de palavras no } \\
\text { discurso do narrador }\end{array}$ & 40 & $4,8 \%$ \\
\hline DI & 28 & $3,4 \%$ \\
\hline Modo híbrido & 19 & $2,3 \%$ \\
\hline DDL & 15 & $1,8 \%$ \\
\hline
\end{tabular}

TABELA 2 - NÚMERO DE VOZES DIFERENTES POR TIPO DE RD

\begin{tabular}{|l|c|}
\hline \multicolumn{1}{|c|}{ Tipo de RD } & Número de vozes diferentes no romance \\
\hline DD & $29^{310}$ \\
\hline DIL & 17 \\
\hline DI & 13 \\
\hline Modo híbrido & 13 \\
\hline $\begin{array}{l}\text { Reprodução de palavras no discur- } \\
\text { so do narrador }\end{array}$ & 11 \\
\hline DDL & 8 \\
\hline
\end{tabular}

TABELA 3 - VOZES QUE PREDOMINAM NO ROMANCE

\begin{tabular}{|l|c|c|}
\hline \multicolumn{1}{|c|}{ Voz citada } & $\begin{array}{c}\text { Número total de falas da } \\
\text { personagem }^{311}\end{array}$ & $\begin{array}{c}\% \\
\text { (na totalidade do romance) }\end{array}$ \\
\hline Emanuel Elói & $99+23$ & $11,9 \%+2,8 \%=14,7 \%$ \\
\hline
\end{tabular}

310 Este número contempla as vozes dos narradores das histórias encaixadas (Bernardes, Lencastre e Emanuel), bem com as falas em coro (e.g., os dois coronéis, os dois casais).

311 Os números que surgem adicionados, em algumas personagens, dizem respeito à sua função de narrador das histórias encaixadas 


\begin{tabular}{|l|c|c|}
\hline Maciel Bernardes & $95+23$ & $11,4 \%+2,8 \%=14,2 \%$ \\
\hline Maria das Dores & 98 & $11,8 \%$ \\
\hline Amílcar Lencastre & $86+10$ & $10,3 \%+1,2 \%=11,5 \%$ \\
\hline Narrador & 72 & $8,7 \%$ \\
\hline Outras vozes & 61 & $7,3 \%$ \\
\hline
\end{tabular}

\section{TABELA 4 - DISCURSO DIRETO}

\begin{tabular}{|l|c|c|}
\hline \multicolumn{1}{|c|}{ Voz citada } & Falas em DD ${ }^{312}$ & $\begin{array}{c}\% \\
\text { (na totalidade do discurso da personagem) }\end{array}$ \\
\hline Maciel Bernardes & $75+23=98$ & $9 \%+2,8 \%=11,8 \%$ \\
\hline Emanuel Elói & $77+18=95$ & $9,3 \%+2,2 \%=11,5 \%$ \\
\hline Maria das Dores & 89 & $10,7 \%$ \\
\hline Amílcar Lencastre & $78+10=88$ & $9,4 \%+1,2 \%=10,6 \%$ \\
\hline Narrador & 60 & $7,2 \%$ \\
\hline Outras vozes & 42 & $5 \%$ \\
\hline
\end{tabular}

TABELA 5 - DISCURSO INDIRETO LIVRE

\begin{tabular}{|l|c|c|}
\hline \multicolumn{1}{|c|}{ Voz citada } & Falas em DIL & $\begin{array}{c}\% \\
\text { (na totalidade do discurso da personagem) }\end{array}$ \\
\hline Emanuel Elói & 12 & $1,4 \%$ \\
\hline Outras vozes & 6 & $0,7 \%$ \\
\hline Maciel Bernardes & 5 & $0,6 \%$ \\
\hline Januário & 5 & $0,6 \%$ \\
\hline Maria das Dores & 4 & $0,5 \%$ \\
\hline Amílcar Lencastre, Sandra & $3^{313}$ & $0,4 \%$ \\
\hline
\end{tabular}

312 Cf. supra nota 311.

313 A partir de agora, sempre que for indicada mais do que uma voz citada, nas tabelas, o número de ocorrências diz respeito a cada uma das personagens. 
TABELA 6 - REPRODUÇÃo DE PALAVRAS NO DISCURSO DO NARRADOR

\begin{tabular}{|l|c|c|}
\hline \multicolumn{1}{|c|}{ Voz citada } & $\mathbf{N}^{\mathbf{0}}$ de ocorrências & $\begin{array}{c}\% \\
\text { (na totalidade do discurso da personagem) }\end{array}$ \\
\hline Narrador & $\mathbf{1 2}$ & $\mathbf{1 , 4 \%}$ \\
\hline Maciel Bernardes & 8 & $1,0 \%$ \\
\hline Outras vozes & 6 & $0,7 \%$ \\
\hline Januário, Jornalistas & 3 & $0,4 \%$ \\
\hline Maria José & 2 & $0.2 \%$ \\
\hline
\end{tabular}

\section{TABELA 7 - DISCURSO INDIRETO}

\begin{tabular}{|l|c|c|}
\hline \multicolumn{1}{|c|}{ Voz citada } & Falas em DI & $\begin{array}{c}\% \\
\text { (na totalidade do discurso da personagem) }\end{array}$ \\
\hline Emanuel Elói & $1+5^{314}$ & $0,1 \%+0,6 \%=0,7 \%$ \\
\hline Maciel Bernardes & 4 & $0,5 \%$ \\
\hline $\begin{array}{l}\text { Amílcar Lencastre, Maria } \\
\text { José, Outras vozes }\end{array}$ & 3 & $0,4 \%$ \\
\hline Januário, Maria das Dores & 2 & $0,2 \%$ \\
\hline
\end{tabular}

TABELA 8 - MODO HÍBRIDO

\begin{tabular}{|l|c|c|}
\hline \multicolumn{1}{|c|}{ Voz citada } & $\begin{array}{c}\text { Falas em modo } \\
\text { híbrido }\end{array}$ & $\begin{array}{c}\% \\
\text { (na totalidade do discurso da personagem) }\end{array}$ \\
\hline Emanuel Elói & 3 & $0,4 \%$ \\
\hline Outras vozes & 3 & $0,4 \%$ \\
\hline Maria das Dores, Januário & 2 & $0,2 \%$ \\
\hline
\end{tabular}

314 As cinco ocorrências adicionadas são relativas a Emanuel Elói como narrador de histórias encaixadas. 
TABELA 9 - DISCURSO DIRETO LIVRE

\begin{tabular}{|l|c|c|}
\hline \multicolumn{1}{|c|}{ Voz citada } & Falas em DDL & $\begin{array}{c}\% \\
\text { (na totalidade do discurso da personagem) }\end{array}$ \\
\hline Emanuel Elói & 6 & $0,7 \%$ \\
\hline Maciel Bernardes, Sandra & 2 & $0,2 \%$ \\
\hline $\begin{array}{l}\text { Januário, Maria José, } \\
\text { Nelson Lencastre, Outras } \\
\text { vozes }\end{array}$ & 1 & $0,1 \%$ \\
\hline
\end{tabular}




\section{ANEXO 5 - O MODO HÍBRIDO EM FANTASIA PARA Dois CORONÉIS E UMA PISCINA, DE MÁrio DE CA R V A L H O}

\section{TABELA 1 - OCORRÊNCIAS EM MODO HíBRIDO}

\begin{tabular}{|l|c|c|}
\hline \multicolumn{1}{|c|}{ Voz citada } & $\begin{array}{c}\text { Falas em modo híbrido } \\
\text { (em 19 ocorrências) }\end{array}$ & $\begin{array}{c}\% \\
\text { (na totalidade do discurso da personagem) }\end{array}$ \\
\hline Emanuel Elói & 3 & $0,4 \%$ \\
\hline Outras vozes & 3 & $0,4 \%$ \\
\hline Maria das Dores & 2 & $0,2 \%$ \\
\hline Januário & 2 & $0,2 \%$ \\
\hline Amílcar Lencastre & 1 & $0,1 \%$ \\
\hline Angelina & 1 & $0,1 \%$ \\
\hline Jornalista de Beja & 1 & $0,1 \%$ \\
\hline Maciel Bernardes & 1 & $0,1 \%$ \\
\hline Maria José & 1 & $0,1 \%$ \\
\hline Melro & 1 & $0,1 \%$ \\
\hline Nelson Lencastre & 1 & $0,1 \%$ \\
\hline Sandra & 1 & $0,1 \%$ \\
\hline Tio de Emanuel & 1 & $0,1 \%$ \\
\hline
\end{tabular}

\section{TABELA 2 - OCORRENCIAS E CARACTERÍSTICAS DO MODO HÍBRIDO NO ROMANCE 315}

\begin{tabular}{|l|l|l|l|}
\hline Voz citada & \multicolumn{1}{|c|}{ Transcrição da fala da personagem } & Página & Descrição da ocorrência \\
\hline Sandra & $\begin{array}{l}\text { «Injustiça!, concluía Sandra, as canções, a } \\
\text { música deviam ser de toda a gente, como } \\
\text { as esferográficas, os clips, os isqueiros. O } \\
\text { primeiro que chegar pega, e leva. Ago- } \\
\text { ra esta coisa de estar a proteger o egois- } \\
\text { mo duns tipos que lá por serem autores } \\
\text { só querem é lucro, ganhuça, ganhuça, } \\
\text { francamente, não estava certo.» }\end{array}$ & 50 & $\begin{array}{l}\text { Coexistência de traços de } \\
\text { DD (Presente e traços ora- } \\
\text { lizantes) com traços de DIL } \\
\text { (Imperfeito) }\end{array}$ \\
\hline
\end{tabular}

315 Os exemplos seguem a ordenação por página. As ocorrências em modo híbrido estão sublinhadas. 


\begin{tabular}{|c|c|c|c|}
\hline Voz citada & Transcrição da fala da personagem & Página & Descrição da ocorrência \\
\hline Januário & $\begin{array}{l}\text { "Chamava-se Januário e assim declarou } \\
\text { com um rijo aperto de mão, por cima do } \\
\text { banco, a um atónito Emanuel que seguia } \\
\text { atrás, onde Sandra o tinha deposto, aban- } \\
\text { donada pelo espanto qualquer resistên- } \\
\text { cia." }\end{array}$ & 55 & $\begin{array}{l}\text { DI com elisão da conjunção } \\
\text { subordinativa }\end{array}$ \\
\hline $\begin{array}{l}\text { Emanuel } \\
\text { Elói }\end{array}$ & $\begin{array}{l}\text { "Que não, fazia-se tarde, disse Emanuel, } \\
\text { sem saber como explicar que não era } \\
\text { professor - tomara ele aprender - e que } \\
\text { o título de mestre no xadrez não tinha } \\
\text { que ver com graus académicos." }\end{array}$ & 56 & $\begin{array}{l}\text { Coexistência de traços de } \\
\text { DD (verbo dicendi) com } \\
\text { traços de DI (conjunção su- } \\
\text { bordinativa + Imperfeito) }\end{array}$ \\
\hline Januário & $\begin{array}{l}\text { "Enfiava as gambas inteiras na boca, mas- } \\
\text { tigava-as e cuspia os tegumentos esmaga- } \\
\text { dos para um prato. [...] } \\
\text { Aquela, segredou, era a Natacha, uma } \\
\text { russa que trabalhava num estabeleci- } \\
\text { mento nocturno que explorava (ele dizia } \\
\text { "orientava") para ai." }\end{array}$ & 57 & $\begin{array}{l}\text { Coexistência de traços de } \\
\text { DD (verbo dicendi) com } \\
\text { traços de DIL (Imperfeito e } \\
\text { traços oralizantes) }\end{array}$ \\
\hline $\begin{array}{l}\text { Maciel } \\
\text { Bernardes }\end{array}$ & $\begin{array}{l}\text { "Se trazia uma varinha de freixo, inqui- } \\
\text { riu o coronel, com ar de quem não acre- } \\
\text { ditava muito na coisa, mas estava a ceder } \\
\text { ao preconceito por instigação alheia, su- } \\
\text { postamente da mulher." }\end{array}$ & 66 & $\begin{array}{l}\text { Coexistência de traços de } \\
\text { DD (verbo dicendi) com } \\
\text { traços de DI (conjunção } \\
\text { subordinativa + Imperfeito, } \\
\text { próprios da interrogativa in- } \\
\text { direta e, consequentemente, } \\
\text { ausência do ponto de inter- } \\
\text { rogação) }\end{array}$ \\
\hline $\begin{array}{l}\text { Maria das } \\
\text { Dores }\end{array}$ & $\begin{array}{l}\text { "Maria das Dores esperava-os junto do } \\
\text { Renault Quatro. Se não ficava para jan- } \\
\text { tar?, perguntou." }\end{array}$ & 69 & $\begin{array}{l}\text { Coexistência de traços de } \\
\text { DD (verbo dicendi e ponto } \\
\text { de interrogação) com traços } \\
\text { de DI (conjunção subordi- } \\
\text { nativa e Imperfeito) }\end{array}$ \\
\hline Maria José & $\begin{array}{l}\text { "Pela estrada fora, em bem diversas maté- } \\
\text { rias ia congeminando Maria José: chegara } \\
\text { o momento de aprender a semear e plan- } \\
\text { tar verduras úteis. Beringelas, couve de } \\
\text { Bruxelas, espargos, etc. Há por aí imen- } \\
\text { sos livros, cobertos de figuras coloridas. A } \\
\text { internet mais ajuda. Um investimento em } \\
\text { informação, sacos de sementes, adubos, } \\
\text { umas luvas, um avental, um sacho e um } \\
\text { ancinho, e pronto, viessem os calores e os } \\
\text { frios, as secas e as inundações, os pássa- } \\
\text { ros e os coelhos, que havia ali vocação de } \\
\text { lavradora..." }\end{array}$ & 98 & $\begin{array}{l}\text { Coexistência de traços de } \\
\text { DDL (Presente) com traços } \\
\text { de DIL (traços oralizantes e } \\
\text { Imperfeito) }\end{array}$ \\
\hline
\end{tabular}




\begin{tabular}{|c|c|c|c|}
\hline Voz citada & Transcrição da fala da personagem & Página & Descrição da ocorrência \\
\hline $\begin{array}{l}\text { Emanuel } \\
\text { Elói }\end{array}$ & $\begin{array}{l}\text { "Ambos olhavam para o céu livre, em } \\
\text { frente, que dera para se fechar e só dei- } \\
\text { xar ver a lua por uma nesga que mais } \\
\text { parecia um rasgão nas nuvens. [...] Sem- } \\
\text { pre era mais interessante, convinha Ema- } \\
\text { nuel, olhar para lá que para o carcomido } \\
\text { e violentado tablier do automóvel.» }\end{array}$ & $112-3$ & $\begin{array}{l}\text { Coexistência de traços do } \\
\text { DD (verbo introdutor) com } \\
\text { traços do DI (Imperfeito) }\end{array}$ \\
\hline Angelina & $\begin{array}{l}\text { "Suspiro de Angelina, que tocou ao de } \\
\text { leve com os dedos na cara de Emanuel. } \\
\text { Estava a ficar cansada, confessou." }\end{array}$ & 116 & $\begin{array}{l}\text { Coexistência de traços do } \\
\text { DD (verbo dicendi) com } \\
\text { traços do DI (Imperfeito) }\end{array}$ \\
\hline $\begin{array}{l}\text { Outras } \\
\text { vozes: } \\
\text { eletricista }\end{array}$ & $\begin{array}{l}\text { "Costuma acontecer que o pessoal não } \\
\text { está todo disponível, de maneira que só } \\
\text { lá para o fim do ano, além disso da Ale- } \\
\text { manha tardam com uma encomenda e } \\
\text { o guarda-livros ainda não tem o preçá- } \\
\text { rio pronto, quanto a pedreiros, ninguém } \\
\text { sabe, não, havia um, morava naquela } \\
\text { rua, ou na do lado, ou noutra, mas pare- } \\
\text { ce que foi à Austrália, ao casamento dum } \\
\text { afilhado, e o electricista, solene e mártir, } \\
\text { abre os largos portões de lata canelada } \\
\text { da oficina [...]." }\end{array}$ & 122 & $\begin{array}{l}\text { Coexistência de traços de } \\
\text { DDL (ausência de marca- } \\
\text { dores tipográficos, Presente } \\
\text { do Indicativo, hesitações no } \\
\text { discurso) com traços de DIL } \\
\text { (Imperfeito) }\end{array}$ \\
\hline $\begin{array}{l}\text { Outras } \\
\text { vozes: } \\
\text { eletricista }\end{array}$ & $\begin{array}{l}\text { "[...] e declara que, ui!, pá, é só, só traba- } \\
\text { lho, anda estafadíssimo e ainda por cima } \\
\text { o pessoal foi de férias, não, não pode ser } \\
\text { nada, mesmo que tivesse toda a boa von- } \\
\text { tade, vejam bem, não é de todo possível, } \\
\text { mesmo sendo para o Presidente da Repú- } \\
\text { blica, salvo seja e com todo o respeito pelo } \\
\text { meu coronel." }\end{array}$ & 122 & $\begin{array}{l}\text { Coexistência de traços de DI } \\
\text { (verbo introdutor + conjun- } \\
\text { ção subordinativa, Imperfei- } \\
\text { to) com traços de DD (inter- } \\
\text { jeição, ponto de exclamação, } \\
\text { repetições, determinante pos- } \\
\text { sessivo de } 1^{a} \text { pessoa) }\end{array}$ \\
\hline $\begin{array}{l}\text { Amílcar } \\
\text { Lencastre }\end{array}$ & $\begin{array}{l}\text { "Baixou-se um pouco e deixou que lhe } \\
\text { molhasse as mãos a água lançada para a } \\
\text { piscina pela enorme cornucópia de barro } \\
\text { vermelho. De quem fora a ideia?" }\end{array}$ & 130 & $\begin{array}{l}\text { Coexistência de traços de } \\
\text { DD (ponto de interrogação) } \\
\text { com traços de DI (Pretérito } \\
\text { Mais-que-Perfeito) }\end{array}$ \\
\hline $\begin{array}{l}\text { Tio de } \\
\text { Emanuel }\end{array}$ & $\begin{array}{l}\text { "O telemóvel de Emanuel emitia um uivo } \\
\text { de cão à lua, na ausência dos donos, } \\
\text { quando se tratava de gente menos che- } \\
\text { gada. E aí estava ele a tocar e o tio arre- } \\
\text { piado. Que era melhor não atender, que } \\
\text { era proibido, que desfalcava a atenção." }\end{array}$ & 161 & $\begin{array}{l}\text { DI com elisão do verbo } d i \text { - } \\
\text { cendi }\end{array}$ \\
\hline
\end{tabular}




\begin{tabular}{|c|c|c|c|}
\hline Voz citada & Transcrição da fala da personagem & Página & Descrição da ocorrência \\
\hline Nelson & $\begin{array}{l}\text { "E Nelson, entre vapores odoríficos, co- } \\
\text { meçou a desconfiar de que aquele Tia- } \\
\text { go estava a ser demasiado aprovativo } \\
\text { e aproximativo da sua Neusa. Mas não } \\
\text { disse nada, apenas baforou. Também, se } \\
\text { a levasse, paciência, há mais Marias na } \\
\text { terra. O problema é que a caravana tinha } \\
\text { sido comprada a meias e só havia uma } \\
\text { prestação paga.» }\end{array}$ & 162 & $\begin{array}{l}\text { Coexistência de traços de } \\
\text { DIL (Imperfeito e interjei- } \\
\text { ção) com DDL (Presente) }\end{array}$ \\
\hline Melro & $\begin{array}{l}\text { "À noitinha, havia de se queixar ao melro. } \\
\text { Mudasse-se, veio a dizer o outro." }\end{array}$ & 190 & $\begin{array}{l}\text { Coexistência de traços de DD } \\
\text { (verbo introdutor) com traços } \\
\text { de DI (Imperfeito) }\end{array}$ \\
\hline $\begin{array}{l}\text { Jornalista } \\
\text { de Beja }\end{array}$ & $\begin{array}{l}\text { "A entrevista acabou por ser engrolada à } \\
\text { pressa, em cinco minutos, e começou por } \\
\text { uma questão inesperada. Se o xadrez era } \\
\text { muito difícil..." }\end{array}$ & 209 & $\begin{array}{l}\text { Coexistência de traços do } \\
\text { DI (conjunção subordinativa } \\
\text { + Imperfeito) com traços de } \\
\text { DD (sugestão de pergunta } \\
\text { em DD, embora sem os dois } \\
\text { pontos) }\end{array}$ \\
\hline $\begin{array}{l}\text { Outras } \\
\text { vozes: } \\
\text { conferen- } \\
\text { cista de } \\
\text { Beja }\end{array}$ & $\begin{array}{l}\text { "Emanuel foi deambulando pelas bran- } \\
\text { cas ruas de Beja, metendo o nariz aqui } \\
\text { e além. Havia uma conferência, no Po- } \\
\text { litécnico. Entrou. Numa sala à cunha, } \\
\text { uma matrona muito loura e desenvolta } \\
\text { perorava sobre psicologia canina, como } \\
\text { anunciava no átrio, um papel tratado a } \\
\text { computador, coberto de perfis de cães. } \\
\text { Da porta, Emanuel aprendeu que os rot- } \\
\text { tweiler são excelentes companheiros e } \\
\text { adoram crianças. Quanto aos pitbull, não } \\
\text { há melhor nem mais meiga presença. [...] } \\
\text { Ficassem todos sabendo que não existem } \\
\text { maus cães, existem é maus donos... de } \\
\text { resto para alguma coisa haviam de servir } \\
\text { as companhias de seguros." }\end{array}$ & $210-1$ & $\begin{array}{l}\text { Coexistência de traços de } \\
\text { DDL com traços de DIL (Im- } \\
\text { perfeito) }\end{array}$ \\
\hline $\begin{array}{l}\text { Maria das } \\
\text { Dores }\end{array}$ & $\begin{array}{l}\text { "Maria José confessou que não sabia se- } \\
\text { quer mexer as pedras. Maria das Dores } \\
\text { fazia uma vaga ideia. O pai tinha-lhe } \\
\text { ensinado, em miúda. Ficou de dar uma } \\
\text { ajuda solta, ao marido e ao vizinho." }\end{array}$ & 219 & $\begin{array}{l}\text { DI com elisão do verbo } d i \text { - } \\
\text { cendi e da conjunção subor- } \\
\text { dinativa }\end{array}$ \\
\hline $\begin{array}{l}\text { Emanuel } \\
\text { Elói }\end{array}$ & $\begin{array}{l}\text { "Emanuel deu aos coronéis uns rudimen- } \\
\text { tos de notação, abcissas e coordenadas, } \\
\text { numa linguagem simplificada. Maria das } \\
\text { Dores ajudou. E o moço, que se sentia } \\
\text { como um principiante de natação que ti- } \\
\text { vesse de pôr uns principiantes a nadar } \\
\text { crawl com palavras aladas, propôs que, } \\
\text { então, já agora, jogasse ele de costas, re- } \\
\text { constituindo mentalmente os movimen- } \\
\text { tos." }\end{array}$ & $220-1$ & $\begin{array}{l}\text { Coexistência de traços de } \\
\text { DI (conjunção subordinati- } \\
\text { va + Imperfeito) com traços } \\
\text { de DIL (Imperfeito e traços } \\
\text { oralizantes) }\end{array}$ \\
\hline
\end{tabular}




\section{ANEXO 6316 - VERBOS INTRODUTORES POR TIPO \\ DE RD EM FANTASIA PARA DOIS CORONÉIS E UMA PISCINA, DE MÁRIO DE CARVALHO}

TABELA 1 - VERBOS INTRODUTORES DE DISCURSO DIRETO

\begin{tabular}{|c|c|}
\hline Total de ocorrências em DD & 676 \\
\hline Sem verbo introdutor & 452 \\
\hline Com verbo introdutor & 224 \\
\hline $\begin{array}{l}\text { Total de verbos diferentes } \\
\text { utilizados }\end{array}$ & 74 \\
\hline Verbos dicendi: 57 & $\begin{array}{l}\text { Aconselhar (2) })^{317} \text {, acrescentar, advertir, alegar, } \\
\text { anunciar (2), apelar, atalhar, bradar (4), chamar, } \\
\text { concluir (2), confessar (3), confessar-se, contar (3), } \\
\text { discutir, dizer (46), ecoar, elucidar, esclarecer, esga- } \\
\text { niçar-se, exclamar, explicar (3), explicitar (2), filo- } \\
\text { sofar, flautear, gabar-se, garantir, gritar (5), indagar, } \\
\text { informar, insistir (4), interrogar-se, interromper (2), } \\
\text { ironizar, murmurar (2), observar (5), obtemperar, } \\
\text { ordenar, perguntar (16), perguntar-se, proclamar, } \\
\text { propor, protestar (2), queixar-se (2), ralhar, recitar, } \\
\text { relatar (2), rematar (2), resmonear, resmungar, res- } \\
\text { ponder (17), resumir, segredar (5), sentenciar, suge- } \\
\text { rir, sussurrar (4), trautear, vozeirar }\end{array}$ \\
\hline Verbos sentiendi: 17 & $\begin{array}{l}\text { Admirar, admirar-se (2), ameaçar, aprovar, assus- } \\
\text { tar-se, brincar, comover-se, compreender (2), consi- } \\
\text { derar (2), desconfiar, entusiasmar-se, exultar, pensar } \\
\text { (13), preocupar-se, reflectir, sobressaltar-se, surpre- } \\
\text { ender-se (2) }\end{array}$ \\
\hline Combinatórias fixas: 5 & $\begin{array}{l}\text { Desejar bons dias, fazer conversa, mudar de tom, } \\
\text { querer saber (2), resumir-se com duas palavras }\end{array}$ \\
\hline Combinatórias livres: 11 & $\begin{array}{l}\text { Aparecer a prosa, aplicar-se a prestar consolação, } \\
\text { atirar a resposta, emitir falas, estar a dar para as per- } \\
\text { guntas, ouvir uma voz, produzir discurso, produzir } \\
\text { opiniões literárias, repristinar a declaração, soltar-se } \\
\text { a voz, vir com uma teoria }\end{array}$ \\
\hline Uso metafórico de verbos: 1 & Rosnar (3) $)^{318}$ \\
\hline
\end{tabular}

316 As tabelas foram hierarquizadas de acordo com o peso que cada um dos modos de RD tem no romance.

317 O número de ocorrências de cada verbo, em todos os tipos de RD, está registado entre parênteses. Por defeito, não havendo nenhuma indicação, trata-se de uma única ocorrência.

318 Este verbo é utilizado com as seguintes personagens: Emanuel, Januário e Maria das Dores. 
TABELA 2 - VERBOS INTRODUTORES DE DISCURSO INDIRETO LIVRE

\begin{tabular}{|l|l|}
\hline Total de ocorrências em DIL & 54 \\
\hline Sem verbo introdutor & 50 \\
\hline Com verbo introdutor & 4 \\
\hline Total de verbos diferentes utilizados & 2 \\
\hline Verbos dicendi: $\mathbf{1}$ & Prever \\
\hline Verbos sentiendi: $\mathbf{1}$ & Pensar \\
\hline Combinatórias fixas: $\mathbf{1}$ & Estar de acordo \\
\hline Combinatórias livres: $\mathbf{1}$ & Vir com uma conversa \\
\hline
\end{tabular}

\section{TABELA 3 - VERBOS INTRODUTORES NA REPRODUÇÃO DE PALAVRAS NO DISCURSO DO NARRADOR}

\begin{tabular}{|l|l|}
\hline Total de ocorrências no discurso do narrador & 40 \\
\hline Sem verbo introdutor & 30 \\
\hline Com verbo introdutor & 10 \\
\hline Total de verbos diferentes utilizados & 2 \\
\hline Verbos dicendi: $\mathbf{2}$ & Chamar (4), dizer (4) \\
\hline Combinatórias fixas: $\mathbf{1}$ & Tratar por \\
\hline Combinatórias livres: $\mathbf{1}$ & Soltar um garganteio selvagem \\
\hline
\end{tabular}

TABELA 4 - VERBOS INTRODUTORES DE DISCURSO INDIRETO

\begin{tabular}{|l|l|}
\hline Total de ocorrências em DI & 29 \\
\hline Total de verbos diferentes utilizados & 17 \\
\hline Verbos dicendi: $\mathbf{1 5}$ & $\begin{array}{l}\text { Afiançar, anunciar, avisar, confessar, confiden- } \\
\text { ciar, declarar, dizer (2), explicar (3), indagar, } \\
\text { inquirir, interrogar-se, jurar, perguntar (4), pro- } \\
\text { por-se, responder (3) }\end{array}$ \\
\hline Verbos sentiendi: $\mathbf{2}$ & Considerar, reflectir \\
\hline Combinatórias fixas: $\mathbf{3}$ & Fazer perguntas, fazer notar, querer saber \\
\hline
\end{tabular}


TABELA 5 - VERBOS INTRODUTORES DE MODO HÍBRIDO

\begin{tabular}{|l|l|}
\hline Total de ocorrências em modo híbrido & 18 \\
\hline Sem verbo introdutor & 6 \\
\hline Com verbo introdutor & 12 \\
\hline Total de verbos diferentes utilizados & 10 \\
\hline Verbos dicendi: 9 & $\begin{array}{l}\text { Confessar, convir, declarar (2), dizer (2), in- } \\
\text { quirir, perguntar, perorar, propor, segredar }\end{array}$ \\
\hline Verbos sentiendi: $\mathbf{1}$ & Congeminar \\
\hline Combinatórias livres: $\mathbf{1}$ & Começar por uma questão \\
\hline
\end{tabular}

TABELA 6 - VERBOS INTRODUTORES DE DISCURSO DIRETO LIVRE

\begin{tabular}{|l|l|}
\hline Total de ocorrências em DDL & 15 \\
\hline Sem verbo introdutor & 11 \\
\hline Com verbo introdutor & 4 \\
\hline Total de verbos diferentes utilizados & 3 \\
\hline Verbos dicendi: 2 & Contar, relatar \\
\hline Verbos sentiendi: 1 & Preocupar-se \\
\hline Combinatórias livres: 1 & Entoar loas \\
\hline
\end{tabular}




\title{
ANEXO 7 - VERBOS INTRODUTORES POR PERSONAGEM EM FANTASIA PARA DOIS CORONEIS E UMA PISCINA, DE MÁRIO DE CARVALHO
}

\begin{abstract}
TABELA 1 - VERBOS INTRODUTORES DE RD, POR PERSONAGEM 319
\end{abstract}

\begin{tabular}{|l|l|}
\hline \multicolumn{1}{|c|}{ Voz } & \multicolumn{1}{c|}{ Verbos } \\
\hline Amílcar Lencastre & Dizer (4), perguntar (3) \\
\hline Emanuel Elói & Dizer/ pensar (8), responder (4) \\
\hline Januário & Dizer/ explicar (2) \\
\hline Maciel Bernardes & Dizer (7), pensar/ perguntar (3) \\
\hline Maria das Dores & Dizer (6), perguntar (4) \\
\hline Maria José & Dizer (6) \\
\hline Neusa & Gritar (2) \\
\hline Outras vozes & Dizer (3), insistir (2) \\
\hline Tiago & Dizer (2) \\
\hline
\end{tabular}

\section{TABELA 2 - VERBOS/COMBINATÓRIAS DA ISOTOPIA DO RUÍDO, POR PERSONAGEM}

\begin{tabular}{|l|l|}
\hline \multicolumn{1}{|c|}{ Verbo } & \multicolumn{1}{c|}{ Voz } \\
\hline Bradar & $\begin{array}{l}\text { Amílcar Lencastre, Eleutério, Maria José, Ou- } \\
\text { tras vozes }\end{array}$ \\
\hline Ecoar & Emanuel narrador \\
\hline Entoar loas & Maciel Bernardes \\
\hline Esganiçar-se & Outras vozes \\
\hline Flautear & Amílcar Lencastre \\
\hline
\end{tabular}

319 Foram registados apenas os dois verbos mais utilizados para cada uma das personagens mais relevantes no romance. Entre parênteses, está o número de ocorrências. Quando se verifica apenas uma ocorrência, o verbo não é contabilizado nesta tabela. 


\begin{tabular}{|l|l|}
\hline Gritar & $\begin{array}{l}\text { Jornalistas, Emanuel narrador, Neusa, Outras } \\
\text { vozes }\end{array}$ \\
\hline Recitar & Amílcar Lencastre \\
\hline Rosnar & Januário \\
\hline Soltar um garganteio selvagem & Claquistas \\
\hline Soltar-se a voz & Outras vozes \\
\hline Trautear & Sandra \\
\hline Vozeirar & Maciel Bernardes \\
\hline
\end{tabular}




\section{ANEXO 8 - FALAS DE MARIA DAS DORES}

\begin{tabular}{|c|c|}
\hline Verbos & $\begin{array}{l}\text { Ginjar-se (29), desamanhar (29), amandar (29), acalcar (30), esfalper- } \\
\text { rar (30), lixar (30 e 139), desembuchar (40), desbocar (111), gramar } \\
\text { (111), bispar (131), papar (139), marrar (139), enrolar (184), fornicar } \\
\text { (184), empernar (217) }\end{array}$ \\
\hline Nomes & $\begin{array}{l}\text { Pardalada (9), mânfio (30), tusto (111), treta (139), copázio (140), } \\
\text { gajo (186) }\end{array}$ \\
\hline Adjetivos & Pifado (132), choninhas (140), ralado (183) \\
\hline Advérbios & «Népias» (186) \\
\hline Linguagem popular & «mai-la» (87) \\
\hline Insultos & $\begin{array}{l}\text { "não me fodam" (29), merda (29, } 32 \text { e 139), sacanas (30), camandro } \\
\text { (30), porra (63), puta (63 e 132), caraças (63 e 136), cabrão (111), } \\
\text { dum raio (139), o tanas (183), catano (183), ir encher-se de moscas } \\
\text { (186), abécula (186), sonso (217) }\end{array}$ \\
\hline Expressões feitas & $\begin{array}{l}\text { Abafar os gargarejos (30), fechar o quiosque (30), mangar com a tro- } \\
\text { pa (30), «Lavradora era a sua tia» (40), (a)mandar um tiro nos cornos } \\
\text { (63), "Macacos me mordam» (87), fornicar a vida (111)/ fornicar o } \\
\text { juízo (139), «Essa não engravida" (111), cheio de nove horas (111), } \\
\text { mandar bugiar à espanhola (112), caixa dos pirolitos (142), vir de } \\
\text { carrinho (182), fazer frenicoques (182), mata e esfola (183), ter a faca } \\
\text { e o queijo na mão (183), tirar o tapete (183), dar de frosques (184), } \\
\text { estar de trombas (184), pianinho (184), mostrar cagança (184), en- } \\
\text { cher o paiol (185), encanar a perna à rã (186), fazer o ninho atrás da } \\
\text { orelha (186), tratar às três pancadas (186), não perceber peva (186), } \\
\text { jogar nesse tabuleiro (186), estar-se nas tintas (186), dar tempo de } \\
\text { antena (186) }\end{array}$ \\
\hline Provérbios & $\begin{array}{l}\text { A cabra puxa sempre para o monte (184) } \\
\text { Tudo como dantes, quartel-general em Abrantes (184) } \\
\text { Quem não presta para comer... (218) }\end{array}$ \\
\hline
\end{tabular}




\section{ANEXO 9 - CLAQUE DE FUTEBOL}

TABELA 1 - TRANSCRIÇÕES DO ROMANCE

\begin{tabular}{|c|c|}
\hline Página 105 & $\begin{array}{l}\text { "clamor", "inusitado", "brutalmente abafada", "ruído [...] a avantajar-se, medo- } \\
\text { nho", "grande ronco", "espessa algazarra", "gritada", "energia já enrouquecida", } \\
\text { "ressoar", "gana e estrépito" }\end{array}$ \\
\hline Página 106 & $\begin{array}{l}\text { "disparava vibrações", «estremecer os ares» «berrar mais estridente", "rugido [...] } \\
\text { arrasador", "alarido que atroava os ares", "barulho do vozeio", "aos altos e bai- } \\
\text { xos", «estalava em estrondeio", "som de pancadas em cadência que ecoavam } \\
\text { fortemente» }\end{array}$ \\
\hline Página 107 & 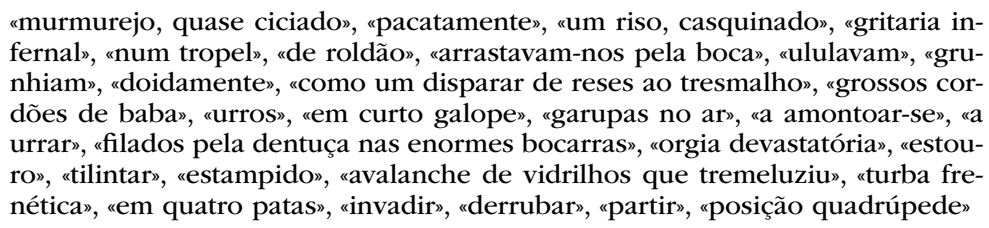 \\
\hline Página 108 & $\begin{array}{l}\text { "escoucinhar à doida", "Soou o silvo do alarme", "destroços [...] que se acumu- } \\
\text { lavam uns sobre os outros, esfarrapados", "grande lixeira", "ruído de pancadas", } \\
\text { "vidros quebrados", "restolhar", "atirados para fora", "Tranquilamente", "trope- } \\
\text { ava", "posição tetrápode", "lançar com força", "que traziam nuns saquitéis ao } \\
\text { pescoço", "desferindo num rápido movimento", "fincando-se firmes nos joelhos } \\
\text { e pés posteriores", "Excelentes catapultas vivas", "vidros desirmanados", "turba", } \\
\text { "que se precipitou", "quebrou", "arremessou", "num estardalhaço tremendo", "os } \\
\text { primeiros fogaréus", "farripas de chamas saltavam e revolviam-se", "derrame de } \\
\text { lume [...] foi-se apoderando" }\end{array}$ \\
\hline Página 109 & $\begin{array}{l}\text { "Altearam-se com o fogo", "puxados por ele", "clamor", "vociferações", «buzina", } \\
\text { "tocava insistentemente", "OS mutantes", "despojos", "galoparam", "aglomera- } \\
\text { ram-se, empurraram-se, ganiram", "num rodilhão", "crepitar das chamas", "in- } \\
\text { certos clarões rubros" }\end{array}$ \\
\hline
\end{tabular}

TABELA 2 - CLASSES DE PALAVRAS

\begin{tabular}{|l|l|}
\hline Nomes & $\begin{array}{l}\text { clamor, ruído (2x), ronco, algazarra, energia, gana, estrépito, vibração, rugido, } \\
\text { alarido, barulho, vozeio, som, pancada, murmurejo, gritaria, tropel, rês, baba, } \\
\text { urro, galope, garupa, dentuça, bocarra, orgia, estouro, estampido, avalanche, } \\
\text { turba (2x), silvo, destroço, lixeira, pancada, catapulta, estardalhaço, fogaréu, } \\
\text { chama (2x), derrame, lume, fogo, clamor, vociferação, buzina, mutante, despojo, } \\
\text { crepitar, clarão }\end{array}$ \\
\hline Adjetivos & $\begin{array}{l}\text { inusitado, abafado, medonho, grande (3x), espesso, gritado, enrouquecido, ar- } \\
\text { rasador, ciciado, casquinado, infernal, devastatório, frenético, filado, quadrúpe- } \\
\text { de, esfarrapado, quebrado, atirado, tetrápode, rápido, desirmanado, tremendo, } \\
\text { puxado, incerto, rubro }\end{array}$ \\
\hline
\end{tabular}




\begin{tabular}{|l|l|}
\hline Verbos & $\begin{array}{l}\text { avantajar-se, ressoar, disparar, estremecer (2x), atroar, ondular, estalar, ecoar, } \\
\text { arrastar, ulular, grunhir, disparar, amontoar-se, urrar, tilintar, tremeluzir, invadir, } \\
\text { derrubar, partir, escoucinhar, soar, acumular, restolhar, tropear, lançar, desferir, } \\
\text { precipitar-se, quebrar, arremessar, saltar, revolver-se, apoderar-se, altear-se, to- } \\
\text { car, galopar, aglomerar-se, empurrar-se, ganir }\end{array}$ \\
\hline Advérbios & $\begin{array}{l}\text { brutalmente, fortemente, doidamente, insistentemente } \\
\text { vs } \\
\text { pacatamente, tranquilamente }\end{array}$ \\
\hline Locuções & $\begin{array}{l}\text { aos altos e baixos, em estrondeio, em cadência, num tropel, de roldão, ao tres- } \\
\text { malho, em curto galope, em quatro patas, à doida, com força, ao pescoço, num } \\
\text { rodilhão }\end{array}$ \\
\hline
\end{tabular}




\section{ANEXO 10 - AS COMPETENCIAS DO NíVELCI DE \\ PROFICI ÊNCIA NOQUADRO EUROPEU COMUM DE \\ REFERÊECIA PARA AS LÍNGUAS}

\section{TABELA 1 - GRELHA PARA AUTOAVALIAÇÃo}

\begin{tabular}{|c|c|c|}
\hline \multirow{2}{*}{ Compreender } & $\begin{array}{c}\text { Compreensão } \\
\text { do oral }\end{array}$ & $\begin{array}{l}\text { Sou capaz de compreender uma exposição longa, mesmo } \\
\text { que não esteja claramente estruturada ou quando a articu- } \\
\text { lação entre as ideias esteja apenas implícita. } \\
\text { Consigo compreender programas de televisão e filmes sem } \\
\text { grande dificuldade. }\end{array}$ \\
\hline & Leitura & $\begin{array}{l}\text { Sou capaz de compreender textos longos e complexos, li- } \\
\text { terários e não literários, e distinguir estilos. Sou capaz de } \\
\text { compreender artigos especializados e instruções técnicas } \\
\text { longas, mesmo quando não se relacionam com a minha } \\
\text { área de conhecimento. }\end{array}$ \\
\hline \multirow[t]{2}{*}{ Falar } & $\begin{array}{l}\text { Interacção } \\
\text { oral }\end{array}$ & $\begin{array}{l}\text { Sou capaz de me exprimir de forma espontânea e fluen- } \\
\text { te, sem dificuldade aparente em encontrar as expressões } \\
\text { adequadas. } \\
\text { Sou capaz de utilizar a língua de maneira flexível e eficaz } \\
\text { para fins sociais e profissionais. Formulo ideias e opiniões } \\
\text { com precisão e adequo o meu discurso ao dos meus inter- } \\
\text { locutores. }\end{array}$ \\
\hline & Produção oral & $\begin{array}{l}\text { Sou capaz de apresentar descrições claras e detalhadas } \\
\text { sobre temas complexos que integrem subtemas, desenvol- } \\
\text { vendo aspectos particulares e chegando a uma conclusão } \\
\text { apropriada. }\end{array}$ \\
\hline Escrever & Escrita & $\begin{array}{l}\text { Sou capaz de escrever textos num estilo fluente e apro- } \\
\text { priado. } \\
\text { Sou capaz de redigir de forma estruturada cartas comple- } \\
\text { xas, relatórios ou artigos que apresentem um caso com } \\
\text { uma tal estrutura lógica que ajude o leitor a aperceber-se } \\
\text { dos pontos essenciais e a memorizá-los. Sou capaz de fa- } \\
\text { zer resumos e recensões de obras literárias e de âmbito } \\
\text { profissional. }\end{array}$ \\
\hline
\end{tabular}

QECRL (2002: 53-5) 
TABELA 2 - ASPETOS QUALITATIVOS DOUSO ORAL DA L I N G U A G E M

\begin{tabular}{|l|l|}
\hline Âmbito & $\begin{array}{l}\text { Tem um bom controlo de uma ampla gama de linguagem, permitindo-lhe } \\
\text { seleccionar determinada formulação para se exprimir num estilo claro sobre } \\
\text { um vasto conjunto de tópicos gerais, académicos, profissionais ou recreativos, } \\
\text { sem ter que restringir aquilo que quer dizer. }\end{array}$ \\
\hline Forrecção & $\begin{array}{l}\text { Mantém de modo consistente um alto grau de correcção gramatical: os erros } \\
\text { são raros, difíceis de detectar e, geralmente, corrigidos à medida que ocor- } \\
\text { rem. }\end{array}$ \\
\hline Interacção & $\begin{array}{l}\text { É capaz de se exprimir de modo fluente e espontâneo, quase sem esforço. } \\
\text { Apenas um assunto conceptualmente difícil pode fazer abrandar o débito } \\
\text { natural de linguagem. }\end{array}$ \\
\hline Coerência & $\begin{array}{l}\text { É capaz de seleccionar uma expressão de uma gama disponível de funções } \\
\text { discursivas como preâmbulo das suas observações, de modo a conservar, } \\
\text { falantente, a palavra e relacionar as suas contribuições com as dos restantes }\end{array}$ \\
\hline $\begin{array}{l}\text { É capaz de produzir um discurso claro, fluente e bem estruturado, demons- } \\
\text { trando um uso controlado de fórmulas organizativas, conectores e dispositi- } \\
\text { vos coesivos. }\end{array}$ \\
\hline
\end{tabular}

QECRL (2002: 56-8)

\section{TABELA 3 - PRODUÇÃO ESCRITA}

\begin{tabular}{|l|l|}
\hline Produção escrita geral & $\begin{array}{l}\text { É capaz de escrever textos bem estruturados, com clareza, sobre } \\
\text { assuntos complexos, sublinhando as questões relevantes e mais } \\
\text { salientes, desenvolvendo e defendendo pontos de vista, acrescen- } \\
\text { tando informações complementares, razões e exemplos pertinen- } \\
\text { tes, e concluindo adequadamente. }\end{array}$ \\
\hline Escrita criativa & $\begin{array}{l}\text { É capaz de escrever descrições claras e pormenorizadas, bem es- } \\
\text { truturadas, desenvolvidas com clareza, e textos criativos num esti- } \\
\text { lo seguro, pessoal, natural e adequado ao leitor visado. }\end{array}$ \\
\hline $\begin{array}{l}\text { Relatórios e ensaios/ } \\
\text { composições }\end{array}$ & $\begin{array}{l}\text { É capaz de escrever exposições claras e estruturadas, sobre assun- } \\
\text { tos complexos, sublinhando as questões pertinentes e salientes. } \\
\text { É capaz de desenvolver e defender pontos de vista, de forma re- } \\
\text { lativamente extensa, acrescentando informações complementares, } \\
\text { razões e exemplos pertinentes. }\end{array}$ \\
\hline
\end{tabular}

QECRL (2002: 96-8) 
TABELA 4 - COMPREENSÃO ORAL

\begin{tabular}{|c|c|}
\hline Compreensão do oral geral & $\begin{array}{l}\text { É capaz de compreender o suficiente para seguir um discurso } \\
\text { longo sobre assuntos complexos e abstractos estranhos à sua } \\
\text { área, embora necessite de confirmar pormenores ocasionais, } \\
\text { especialmente se o sotaque não lhe for familiar. } \\
\text { É capaz de reconhecer um vasto leque de expressões idiomá- } \\
\text { ticas e de coloquialismos, notando as mudanças de registo. } \\
\text { É capaz de seguir um discurso longo, mesmo quando ele } \\
\text { não está claramente estruturado e quando as relações entre } \\
\text { as ideias se encontram implícitas e não são marcadas expli- } \\
\text { citamente. }\end{array}$ \\
\hline $\begin{array}{l}\text { Compreensão da interacção } \\
\text { oral entre falantes nativos }\end{array}$ & $\begin{array}{l}\text { É capaz de seguir com facilidade interacções complexas en- } \\
\text { tre terceiros numa discussão ou num debate de grupo, mes- } \\
\text { mo sobre assuntos abstractos, complexos ou que não lhe são } \\
\text { familiares. }\end{array}$ \\
\hline $\begin{array}{l}\text { Audição ao vivo como } \\
\text { membro de um auditório }\end{array}$ & $\begin{array}{l}\text { É capaz de seguir a maior parte das conferências, discussões } \\
\text { e debates com relativa facilidade. }\end{array}$ \\
\hline $\begin{array}{l}\text { Audição de anúncios e de } \\
\text { instruções }\end{array}$ & $\begin{array}{l}\text { É capaz de extrair informações específicas de anúncios pu- } \\
\text { blicitários com má qualidade sonora e acústica distorcida, p. } \\
\text { ex., numa estação de comboios, num estádio, etc. } \\
\text { É capaz de compreender informações técnicas complexas, } \\
\text { como instruções de utilização, especificações de produtos e } \\
\text { serviços conhecidos. }\end{array}$ \\
\hline $\begin{array}{l}\text { Audição de meios de } \\
\text { comunicação áudio e de } \\
\text { gravações }\end{array}$ & $\begin{array}{l}\text { É capaz de entender uma ampla gama de material áudio gra- } \\
\text { vado ou transmitido, incluindo os usos que não são padrão, } \\
\text { e identificar minúcias, incluindo atitudes implícitas e relações } \\
\text { entre falantes. }\end{array}$ \\
\hline
\end{tabular}

QECRL (2002: 103-5)

TABELA 5 - COMPREENSÃO ESCRITA (LEITURA)

\begin{tabular}{|l|l|}
\hline $\begin{array}{l}\text { Compreensão na } \\
\text { leitura geral }\end{array}$ & $\begin{array}{l}\text { É capaz de entender em pormenor textos longos e complexos relacio- } \\
\text { nados ou não com a sua área de especialidade, desde que possa voltar } \\
\text { a ler as secções difíceis. }\end{array}$ \\
\hline $\begin{array}{l}\text { Leitura de } \\
\text { correspondência }\end{array}$ & $\begin{array}{l}\text { É capaz de entender qualquer correspondência, utilizando pontual- } \\
\text { mente o dicionário. }\end{array}$ \\
\hline
\end{tabular}




\begin{tabular}{|l|l|}
\hline $\begin{array}{l}\text { Leitura para orien- } \\
\text { tação }\end{array}$ & $\begin{array}{l}\text { É capaz de percorrer rapidamente um texto longo e complexo, locali- } \\
\text { zando pormenores relevantes. } \\
\text { É capaz de identificar rapidamente o conteúdo e a relevância de novas } \\
\text { questões, artigos e relatórios acerca de um vasto leque de assuntos } \\
\text { profissionais, decidindo se vale a pena um estudo mais aprofundado. }\end{array}$ \\
\hline $\begin{array}{l}\text { Leitura para obter } \\
\text { informações e argu- } \\
\text { mentos }\end{array}$ & $\begin{array}{l}\text { É capaz de entender em pormenor um vasto leque de textos longos } \\
\text { e complexos, passíveis de ocorrerem na vida social, profissional ou } \\
\text { acadéca, identificando pequenos pormenores que incluem atitudes e } \\
\text { opiniões implícitas ou abertamente expressas. }\end{array}$ \\
\hline $\begin{array}{l}\text { Leitura de instru- } \\
\text { ções }\end{array}$ & $\begin{array}{l}\text { É capaz de entender em pormenor instruções longas e complexas acer- } \\
\text { ca de uma nova máquina ou de um novo procedimento, quer essas } \\
\text { instruções se relacionem com a sua área de especialização quer não, } \\
\text { desde que possa voltar a ler as secções mais difíceis. }\end{array}$ \\
\hline
\end{tabular}

QECRL (2002: 107-9)

\section{TABELA 6 - COMPETÊNCIAS LINGUÍSTICAS}

\begin{tabular}{|c|l|}
\hline Âmbito linguístico geral & $\begin{array}{l}\text { É capaz de seleccionar uma formulação apropriada a partir de } \\
\text { um vasto repertório linguístico para se exprimir com clareza } \\
\text { sem ter que restringir aquilo que quer dizer. }\end{array}$ \\
\hline Amplitude do vocabulário & $\begin{array}{l}\text { Domina um repertório alargado que lhe permite ultrapassar } \\
\text { dificuldades/lacunas com circunlocuções; não é evidente a pro- } \\
\text { cura de expressões ou de estratégias de evitação. Bom domínio } \\
\text { de expressões idiomáticas e coloquialismos. }\end{array}$ \\
\hline Domínio do vocabulário & $\begin{array}{l}\text { Pequenas falhas ocasionais, mas sem erros vocabulares signi- } \\
\text { ficativos. }\end{array}$ \\
\hline Correcção gramatical & $\begin{array}{l}\text { Mantém um nível elevado de correcção gramatical de forma } \\
\text { constante; os erros são raros e difíceis de identificar. }\end{array}$ \\
\hline Domínio fonológico & $\begin{array}{l}\text { É capaz de diversificar a entoação e colocar correctamente o } \\
\text { acento da frase de forma a exprimir subtilezas de significado. }\end{array}$ \\
\hline Domínio ortográfico & $\begin{array}{l}\text { A disposição do texto, os parágrafos e a pontuação são lógicos } \\
\text { e úteis. A ortografia é correcta, apesar de ser possível encontrar } \\
\text { alguns lapsos. }\end{array}$ \\
\hline
\end{tabular}




\begin{tabular}{|l|l|}
\hline \multirow{3}{*}{ Adequação sociolinguística } & $\begin{array}{l}\text { É capaz de reconhecer um vasto leque de expressões idiomá- } \\
\text { ticas e de coloquialismos, e de perceber mudanças de registo; } \\
\text { poderá, todavia, necessitar de confirmar pormenores esporádi- } \\
\text { cos, especialmente se o sotaque não lhe for familiar. } \\
\text { É capaz de utilizar a língua flexivelmente e com eficácia para } \\
\text { fins sociais, incluindo os usos afectivos, os humorísticos e as } \\
\text { subtilezas. }\end{array}$ \\
\hline
\end{tabular}

QECRL (2002: 158, 160, 161, 163, 167, 168, 173)

\section{TABELA 7 - RECEÇÃO DE AUDIOVISUAL}

Ver televisão e filmes

É capaz de seguir filmes que utilizem um grau considerável de calão e de expressões idiomáticas.

QECRL (2002: 110)

TABELA 8 - ESTRATÉGIAS GERAIS DE RECEÇÃO

Identificar indícios e fazer inferências (oral e escrito)

QECRL (2002: 112)
É hábil no uso de indícios contextuais, gramaticais e lexicais de forma a poder inferir atitudes, humores e intenções e prever o que vem a seguir. 


\section{ANEXO 11 - ROTEIRO DE UNIDADE DIDÁTICA}

\section{RELATO DE DISCURSO E IMAGENS IDENTITÁRIAS PORTUGUESAS}

Público-alvo: Alunos de nível C1 de proficiência em Português do Curso Anual de Português para Estrangeiros de 2010/2011 da FLUC

\section{Cadeira: Língua Portuguesa I OBJETIVOS GERAIS}

- Fomentar a competência comunicativa em língua portuguesa (nas suas vertentes linguístico-pragmática, sociocultural, discursiva, estratégica e estético-literária).

- Desenvolver, de forma integrada, as quatro competências linguísticas básicas (Ouvir/ Falar/Ler/Escrever), a partir do estudo do relato de discurso numa obra literária.

- Aprofundar a reflexão metalinguística sobre os mecanismos de reprodução de palavras no discurso.

- Promover a reflexão sobre a realidade social e cultural portuguesa, em confronto com as diferentes mundividências dos discentes.

- Estimular a leitura de textos literários em língua portuguesa.

- Divulgar escritores contemporâneos portugueses.

- Encorajar a autonomia e a responsabilidade do discente na construção progressiva da sua competência comunicativa em português.

\section{CONTEÚDOS}

(i) Linguísticos:

Relato de discurso - formas prototípicas (discurso direto, discurso indireto, discurso indireto livre) e periféricas (discurso direto livre, hibridação de formas); configurações linguísticas e valor expressivo/alcance pragmático. 
(ii) Temáticos:

Imagens do Portugal contemporâneo em Fantasia para dois coronéis e uma piscina, de Mário de Carvalho:

(iii) Nocionais-funcionais ${ }^{320}$ :

Exprimir e descobrir atitudes (acordo/ desacordo, intenções, preferências, emoções)

Persuadir/ argumentar

Estruturar o discurso

Narrar/ descrever

Explicar/comentar/ interpretar

\section{ESTRATÉGIAS/ATIVIDADES}

- Tempestade de ideias, para levantamento de expectativas e hipóteses de interpretação, a partir de materiais icónicos.

- Diálogo alunos-professora e aluno-aluno (trabalho de pares e em grande grupo).

- Leitura e comentário de excertos textuais.

- Resolução e correção de fichas de trabalho.

- Trabalho de grupo.

- Apresentação oral de trabalhos.

- Produção de textos escritos.

\section{MATERIAIS}

- Fantasia para dois coronéis e uma piscina, de Mário de Carvalho.

- Dicionários e gramáticas da língua portuguesa.

- Imagens das capas das edições portuguesa, francesa, croata e espanhola do romance. 
- $\quad$ Fichas de trabalho 321

\section{MODALIDADES DE AVALIAÇÃO}

- Autoavaliação e heteroavaliação (observação direta pela professora).

- Avaliação formativa escrita.

321 Cf. Anexos 12 e 13. 


\section{ANEXO 12 - FICHA DE TRABALHO 1 - RELATO DE D I S C U R S O}

Recorde o que aprendeu sobre reprodução de discurso no discurso e atente no seguinte exemplo, extraído do romance Fantasia para dois coronéis e uma piscina, de Mário de Carvalho, que acabou de ler:

- Pois eu - disse o moço [Emanuel] - fico esta noite em Reguengos, falo com a sua rapariga [de Eleutério, o apicultor] e amanhã, ala, para o Grudemil. (p. 35)

Tendo em conta as coordenadas contextuais apresentadas na segunda coluna dos quadros A., B. e C., reescreva, em discurso indireto (DI), os excertos da fala em discurso direto (DD) de Emanuel Elói, respeitando as indicações.

Compare cada frase de partida com a de chegada e registe, na última coluna, as semelhanças/diferenças entre elas, no que diz respeito às marcas linguísticas de pessoa, tempo e espaço.

A.

\begin{tabular}{|c|c|c|c|}
\hline DD & $\begin{array}{l}\text { Coordenadas contextuais: quem } \\
\text { fala, a quem fala, de quem fala }\end{array}$ & DI & Observações \\
\hline \multirow{3}{*}{$\begin{array}{l}\text { Emanuel dirige-se a } \\
\text { Eleutério: } \\
\text { " - Pois eu [...] fico } \\
{[\ldots] \text { em Reguengos, }} \\
\text { falo com a sua rapa- } \\
\text { riga [...]." }\end{array}$} & $\begin{array}{l}\text { O dono do restaurante de Reguengos } \\
\text { conta à mulher a conversa que ouviu. }\end{array}$ & & \\
\hline & $\begin{array}{l}\text { Emanuel reproduz a Eleutério as pala- } \\
\text { vras que ele próprio proferiu. }\end{array}$ & & \\
\hline & $\begin{array}{l}\text { Eleutério reproduz perante Emanuel } \\
\text { as palavras que este lhe dirigiu. }\end{array}$ & & \\
\hline
\end{tabular}


B.

\begin{tabular}{|c|c|c|c|}
\hline DD & $\begin{array}{c}\text { Coordenadas contextuais: quem fala, a } \\
\text { quem fala, onde fala }\end{array}$ & DI & Observações \\
\hline \multirow{3}{*}{$\begin{array}{l}\text { Emanuel dirige-se a } \\
\text { Eleutério: } \\
\text { "- Pois eu [...] fico } \\
{[\ldots] \text { em Reguengos, }} \\
\text { falo com a sua rapa- } \\
\text { riga e }[\ldots] \text { ala, para o } \\
\text { Grudemil.» }\end{array}$} & $\begin{array}{l}\text { O dono do restaurante, em Reguengos, } \\
\text { conta à mulher a conversa que ouviu. }\end{array}$ & & \\
\hline & $\begin{array}{l}\text { Em Grudemil, alguém conta a um interlo- } \\
\text { cutor as palavras que Emanuel dirigiu a } \\
\text { Eleutério. }\end{array}$ & & \\
\hline & $\begin{array}{l}\text { Em Reguengos, Eleutério reproduz as pala- } \\
\text { vras que Emanuel lhe dirigiu. }\end{array}$ & & \\
\hline
\end{tabular}

C.

\begin{tabular}{|c|c|c|c|}
\hline DD & $\begin{array}{c}\text { Coordenadas contextuais: quem fala, a } \\
\text { quem fala, quando fala }\end{array}$ & DI & Observações \\
\hline \multirow{3}{*}{$\begin{array}{l}\text { Emanuel dirige-se a } \\
\text { Eleutério: } \\
\text { " - Pois eu [...] fico } \\
\text { esta noite em Re- } \\
\text { guengos, falo com a } \\
\text { sua rapariga e ama- } \\
\text { nhã, ala, para o Gru- } \\
\text { demil.» }\end{array}$} & $\begin{array}{l}\text { O dono do restaurante de Reguengos } \\
\text { conta à mulher a conversa que está a ou- } \\
\text { vir naquele momento. }\end{array}$ & & \\
\hline & $\begin{array}{l}\text { Em Grudemil, no dia seguinte, Emanuel } \\
\text { conta a alguém as palavras que dirigiu } \\
\text { a Eleutério. }\end{array}$ & & \\
\hline & $\begin{array}{l}\text { Em Grudemil, uns dias depois, alguém } \\
\text { conta as palavras que Emanuel tinha diri- } \\
\text { gido a Eleutério. }\end{array}$ & & \\
\hline
\end{tabular}


CHAVE DE CORREÇÃO:

A.

\begin{tabular}{|c|c|c|c|}
\hline DD & $\begin{array}{l}\text { Coordenadas contextu- } \\
\text { ais: quem fala, a quem } \\
\text { fala, de quem fala }\end{array}$ & DI & Observações \\
\hline \multirow{3}{*}{$\begin{array}{l}\text { Emanuel diri- } \\
\text { ge-se a Eleu- } \\
\text { tério: } \\
\text { "- Pois eu }[\ldots] \\
\text { fico }[\ldots] \text { em } \\
\text { Reguengos, } \\
\text { falo com a sua } \\
\text { rapariga }[\ldots . . . \text {." }\end{array}$} & $\begin{array}{l}\text { O dono do restaurante de } \\
\text { Reguengos conta à mulher } \\
\text { a conversa que ouviu. }\end{array}$ & $\begin{array}{l}\text { Emanuel disse } \\
\text { a Eleutério que } \\
\text { ficava/fica }^{322} \\
\text { em Reguengos e } \\
\text { falava/fala com } \\
\text { a rapariga de } \\
\text { Eleutério/dele. }\end{array}$ & $\begin{array}{l}\text { DD: } \\
\text { "eu»; "fico"; "Reguengos»; } \\
\text { "falo"; "a sua rapariga" } \\
\text { DI: } \\
\text { [ele] "ficava/fica»; } \\
\text { [ele] "falava/fala»; "rapariga } \\
\text { de Eleutério/dele" }\end{array}$ \\
\hline & $\begin{array}{l}\text { Emanuel reproduz a Eleu- } \\
\text { tério as palavras que ele } \\
\text { próprio proferiu. }\end{array}$ & $\begin{array}{l}\text { Eu disse-lhe que } \\
\text { ficava/fico em } \\
\text { Reguengos e } \\
\text { falava/falo com } \\
\text { a sua rapariga. }\end{array}$ & $\begin{array}{l}\text { DD: } \\
\text { "eu»; "fico"; "Reguengos"; } \\
\text { "falo"; «a sua rapariga" } \\
\text { DI: } \\
\text { [eu] "ficava/fico"; } \\
\text { [eu] "falava/falo»; "a sua ra- } \\
\text { pariga" }\end{array}$ \\
\hline & $\begin{array}{l}\text { Eleutério reproduz peran- } \\
\text { te Emanuel as palavras } \\
\text { que este lhe dirigiu. }\end{array}$ & $\begin{array}{l}\text { Você disse-me } \\
\text { que ficava/fica } \\
\text { em Reguengos, } \\
\text { falava/fala com } \\
\text { a minha rapa- } \\
\text { riga. }\end{array}$ & $\begin{array}{l}\text { DD: } \\
\text { "eu»; "fico"; "Reguengos"; } \\
\text { "falo"; "a sua rapariga" } \\
\text { DI: } \\
\text { [você] "ficava/fica»; } \\
\text { [você] "falava/fala»; } \\
\text { "a minha rapariga" }\end{array}$ \\
\hline
\end{tabular}

322 Seria explicado aos alunos que a forma sublinhada, do Pretérito imperfeito do Indicativo, é a mais correta, sendo contudo aceitável o Presente, em registo informal. Esta observação aplica-se a todos os exemplos que apresentam duas possibilidades de resposta. 
B.

\begin{tabular}{|c|c|c|c|}
\hline DD & $\begin{array}{l}\text { Coordenadas contex- } \\
\text { tuais: quem fala, a } \\
\text { quem fala, onde fala }\end{array}$ & DI & Observações \\
\hline \multirow{3}{*}{$\begin{array}{l}\text { Emanuel diri- } \\
\text { ge-se a Eleutério: } \\
\text { "- Pois eu [...] } \\
\text { fico [...] em Re- } \\
\text { guengos, falo } \\
\text { com a sua rapari- } \\
\text { ga e }[\ldots] \text { ala, para } \\
\text { o Grudemil." }\end{array}$} & $\begin{array}{l}\text { O dono do restaurante } \\
\text { de Reguengos conta à } \\
\text { mulher a conversa que } \\
\text { ouviu. }\end{array}$ & $\begin{array}{l}\text { Emanuel disse a Eleu- } \\
\text { tério que ficava/fica } \\
\text { em Reguengos/aqui, } \\
\text { falava/ fala com a } \\
\text { rapariga de Eleuté- } \\
\text { rio e } i a / v a i / i r i a ~ p a r a \\
\text { o Grudemil. }\end{array}$ & $\begin{array}{l}\text { DD: } \\
\text { "eu»; "fico"; "Reguengos»; } \\
\text { "falo"; "a sua rapariga"; } \\
\text { "Grudemil» } \\
\text { Nota: Elisão de um verbo } \\
\text { de movimento ("Ir», "Se- } \\
\text { guir", "Partir») } \\
\text { DI: } \\
\text { [ele] "ficava/fica»; "Re- } \\
\text { guengos/aqui»; } \\
\text { [ele] «falava/fala»; «a rapari- } \\
\text { ga de Eleutério/dele»; [ele] } \\
\text { "ia/vai/iria"; "Grudemil» }\end{array}$ \\
\hline & $\begin{array}{l}\text { Em Grudemil, alguém } \\
\text { conta as palavras que } \\
\text { Emanuel dirigiu a Eleu- } \\
\text { tério. }\end{array}$ & $\begin{array}{l}\text { Emanuel disse a Eleu- } \\
\text { tério que ficava/ } \\
\text { fica em Reguengos/ } \\
\text { lá, falava/fala com } \\
\text { a rapariga de Eleu- } \\
\text { tério/dele e vinha/ } \\
\text { vem/viria para o } \\
\text { Grudemil/para cá. }\end{array}$ & $\begin{array}{l}\text { DD: } \\
\text { "eu»; "fico"; "Reguengos"; } \\
\text { "falo"; "a sua rapariga"; } \\
\text { "Grudemil" } \\
\text { Nota: Elisão de um verbo } \\
\text { de movimento ("Ir", "Se- } \\
\text { guir", "Partir») } \\
\text { DI: } \\
\text { [ele] "ficava/fica»; "Re- } \\
\text { guengos/lá»; } \\
\text { [ele] ufalava/fala»; "a rapa- } \\
\text { riga de Eleutério/dele»; } \\
\text { [ele] "vinha/vem/viria"; } \\
\text { "Grudemil/cá" }\end{array}$ \\
\hline & $\begin{array}{l}\text { Em Reguengos, Eleu- } \\
\text { tério reproduz as pala- } \\
\text { vras que Emanuel lhe } \\
\text { dirigiu. }\end{array}$ & $\begin{array}{l}\text { Você disse-me que } \\
\text { ficava/fica em Re- } \\
\text { guengos/aqui, fala- } \\
\text { va/fala com a minha } \\
\text { rapariga e ia/vai/irá } \\
\text { para o Grudemil. }\end{array}$ & 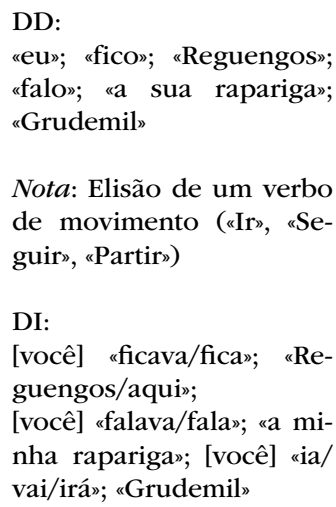 \\
\hline
\end{tabular}


C.

\begin{tabular}{|c|c|c|c|}
\hline DD & $\begin{array}{l}\text { Coordenadas } \\
\text { contextuais: quem } \\
\text { fala, a quem fala, } \\
\text { quando fala }\end{array}$ & DI & Observações \\
\hline \multirow{3}{*}{$\begin{array}{l}\text { Emanuel diri- } \\
\text { ge-se a Eleuté- } \\
\text { rio: } \\
\text { "- Pois eu [...] } \\
\text { fico esta noite } \\
\text { em Reguen- } \\
\text { gos, falo com } \\
\text { a sua rapariga } \\
\text { e amanhã, ala, } \\
\text { para o Grude- } \\
\text { mil.» }\end{array}$} & $\begin{array}{l}\text { O dono do restaurante } \\
\text { de Reguengos conta à } \\
\text { mulher a conversa que } \\
\text { está a ouvir naquele } \\
\text { momento. }\end{array}$ & $\begin{array}{l}\text { Emanuel está a dizer } \\
\text { a Eleutério que fica } \\
\text { esta noite em Re- } \\
\text { guengos/aqui, fala } \\
\text { com a rapariga de } \\
\text { Eleutério/dele e vai/ } \\
\text { irá amanhã para o } \\
\text { Grudemil. }\end{array}$ & $\begin{array}{l}\text { DD: } \\
\text { "eu»; "fico»; "esta noite»; } \\
\text { "Reguengos"; "falo»; "a sua } \\
\text { rapariga»; "amanhã»; "Gru- } \\
\text { demil» } \\
\text { Nota: Elisão de um verbo } \\
\text { de movimento ("Ir», "Se- } \\
\text { guir», "Partir») } \\
\text { DI: } \\
\text { [ele] «está a dizer»; [ele] } \\
\text { "fica»; "esta noite»; "Re- } \\
\text { guengos/aqui"; } \\
\text { [ele] "fala»; "a rapariga de } \\
\text { Eleutério/dele»; [ele] "vai/ } \\
\text { irá»; "amanhã»; "Grudemil» }\end{array}$ \\
\hline & $\begin{array}{l}\text { Em Grudemil, no dia } \\
\text { seguinte, Emanuel con- } \\
\text { ta a alguém as palavras } \\
\text { que dirigiu a Eleutério. }\end{array}$ & $\begin{array}{l}\text { Eu disse a Eleutério } \\
\text { que ficava ontem em } \\
\text { Reguengos/lá, falava } \\
\text { com a rapariga dele e } \\
\text { vinha/viria hoje para } \\
\text { o Grudemil/para cá. }\end{array}$ & $\begin{array}{l}\text { DD: } \\
\text { "eu»; "fico»; "esta noite»; } \\
\text { "Reguengos"; "falo"; "a sua } \\
\text { rapariga»; "amanhã»; "Gru- } \\
\text { demil» } \\
\text { Nota: Elisão de um verbo } \\
\text { de movimento ("Ir", «Se- } \\
\text { guir», "Partir») } \\
\text { DI: } \\
\text { [eu] "ficava»; "Ontem», "Re- } \\
\text { guengos/lá»; [eu] "falava»; } \\
\text { "a rapariga dele»; [eu] } \\
\text { "vinha/viria"; "hoje»; "Gru- } \\
\text { demil/cá" }\end{array}$ \\
\hline & $\begin{array}{l}\text { Em Grudemil, uns dias } \\
\text { depois, alguém conta } \\
\text { as palavras que Ema- } \\
\text { nuel tinha dirigido a } \\
\text { Eleutério. }\end{array}$ & $\begin{array}{l}\text { Ele disse a Eleutério } \\
\text { que ficava naquela } \\
\text { noite em Reguengos/ } \\
\text { lá, falava com a rapa- } \\
\text { riga dele e vinha/ } \\
\text { viria no dia seguin- } \\
\text { te para o Grudemil/ } \\
\text { para cá. }\end{array}$ & $\begin{array}{l}\text { DD: } \\
\text { «eu»; "fico»; "esta noite»; } \\
\text { "Reguengos»; "falo»; "a sua } \\
\text { rapariga»; "amanhã»; "Gru- } \\
\text { demil» } \\
\text { Nota: Elisão de um verbo } \\
\text { de movimento ("Ir», «Se- } \\
\text { guir», "Partir») } \\
\text { DI: } \\
\text { [ele] "ficava»; "naquela noi- } \\
\text { te», "Reguengos/lá»; [ele] } \\
\text { "falava»; "a rapariga dele»; } \\
\text { [ele] "vinha/viria»; "no dia } \\
\text { seguinte»; "Grudemil/cá» }\end{array}$ \\
\hline
\end{tabular}




\section{ANEXO 13 - FICHA DE TRABALHO 2 - VERBOS IN- TRODUTORES DE RELATO DE DISCURSO}

A. Releia os seguintes excertos do romance Fantasia para dois coronéis e uma piscina, de Mário de Carvalho.

Tendo em conta a leitura que fez da obra, reescreva cada um deles, utilizando um verbo que possa introduzir o DD das personagens que o produzem.

\begin{tabular}{|c|c|}
\hline Excerto do romance & Reescrita do excerto \\
\hline $\begin{array}{l}\text { [DD de Emanuel, p. } 35] \\
\text { O automóvel patinou na massa de areia, deu-se a uns ziguezagues } \\
\text { perigosos, mas Emanuel firmou-se bem ao volante. } \\
\text { - Quer vossemecê que eu fale com ela? }\end{array}$ & \\
\hline $\begin{array}{l}\text { [DD do organizador da festa de Grudemil, p. 47] } \\
\text { O homem segurou familiarmente o braço de Emanuel, e para a ra- } \\
\text { pariga: } \\
\text { - Sandra, minha amiga, bem vês, vais fazer um favor à organização: } \\
\text { conduzes aqui o professor à tenda dos ranchos. Já vamos atrasados, } \\
\text { bem vês. É para começar às cinco, não é, professor? }\end{array}$ & \\
\hline $\begin{array}{l}\text { [DD de Sandra, p. 47] } \\
\text { Sandra parou, deixou que o associativo bigodudo lhe arrebatasse os } \\
\text { sacos, deu uma volta à pastilha elástica que tinha na boca, cruzou os } \\
\text { braços e sorriu para Emanuel: } \\
\text { - 'bora! }\end{array}$ & \\
\hline $\begin{array}{l}\text { [DD de Januário, p. 60] } \\
\text { O homem avançava para ele: } \\
\text { - Anda cá, meu cabrão, que eu vou-te mostrar o que faço aos bato- } \\
\text { teiros - passou pela mesa e agarrou num candelabro. }\end{array}$ & \\
\hline $\begin{array}{l}\text { [DD de Maria das Dores, p. 63] } \\
\text { Nem assim o coronel, todo torto e quase a pé-coxinho, deixou de } \\
\text { se levantar, gemendo, para ir procurar a Uzi no armário e trazê-la } \\
\text { para o aconchego da almofada. "Você nem doente larga essa porra. } \\
\text { Parece que casou com a puta da metralhadora, ou o caraças. Ao me- } \\
\text { nos se amandasse um tiro nos cornos acabavam-se-lhe as chatices.» }\end{array}$ & \\
\hline $\begin{array}{l}\text { [DD de Maria das Dores, p. } 68 \text { ] } \\
\text { Maria das Dores riu: } \\
\text { - Mas é amoroso... e para além de encontrar a pu... ou melhor, a } \\
\text { mer... quer dizer, a... água, que outros talentos tem? }\end{array}$ & \\
\hline $\begin{array}{l}\text { [DD de Angelina, p. 110] } \\
\text { - O quê? Parece que é parvo, o raio do moço! - E a rapariga, pisan- } \\
\text { do o pé de Emanuel, calcou o acelerador com força. }\end{array}$ & \\
\hline
\end{tabular}




\begin{tabular}{|c|c|}
\hline Excerto do romance & Reescrita do excerto \\
\hline $\begin{array}{l}\text { [DD de Felismina, p. 130] } \\
\text { Felismina estava desconsolada: } \\
\text { - Era eu moça pequena, e o lavrador do Monte dos Chocalhos } \\
\text { encontrou um pote dos mouros que havia debaixo duma oliveira e } \\
\text { aquilo eram só libras de ouro a correr. }\end{array}$ & \\
\hline $\begin{array}{l}\text { [DD de Bernardes, p. 143] } \\
\text { - Olhe, Maria das Dores. Tomáramos nós! } \\
\text { Fechou a luz e voltou-se para o outro lado. }\end{array}$ & \\
\hline $\begin{array}{l}\text { [DD de Neusa, p. 158] } \\
\text { E a rapariga que ia sentada ao lado de Nelson, nova namorada em } \\
\text { folha: } \\
\text { - Eu queria é que esta noite nenhum de vocês ressonasse, senão } \\
\text { amanhã não estou em condições de guiar e alombam os dois sozi- } \\
\text { nhos com a condução. }\end{array}$ & \\
\hline $\begin{array}{l}\text { [DD de Nelson, p. 159] } \\
\text { - Tudo preto é que eu não concordo - impôs-se Nelson. Um gajo } \\
\text { vem aqui deixar o tag, porreiro, tudo bem, agora borrar a merda da } \\
\text { placa de preto é que, francamente, pá. }\end{array}$ & \\
\hline $\begin{array}{l}\text { [DD de Tiago, p. 164] } \\
\text { Tiago fez-se modesto: } \\
\text { - Ora, isto comparado com aquela tua ideia da instalação toda feita } \\
\text { de patas de coelho e uma pipa vermelha lá dentro... - abanou a } \\
\text { cabeça por não encontrar palavras. }\end{array}$ & \\
\hline
\end{tabular}

B. Substitua cada uma das expressões sublinhadas da coluna da esquerda por um único verbo com o mesmo significado.

\begin{tabular}{|l|l|}
\hline «entoar loas» (p. 32) & \\
\hline «a prestar consolação» (p. 34) & \\
\hline «está a produzir o seguinte [...] discurso» (p. 73) & \\
\hline «olhou para mim [...] numa imploração» (p. 93) & \\
\hline «Foi fazendo conversa» (p. 94) & \\
\hline «vinha com uma teoria» (p. 147) & \\
\hline "produziram opiniões» (p. 207) & \\
\hline
\end{tabular}




\section{CHAVE DE CORREÇÃO}

A.

\begin{tabular}{|c|c|}
\hline Excerto do romance & $\begin{array}{c}\text { Reescrita do } \\
\text { excerto }^{323}\end{array}$ \\
\hline $\begin{array}{l}\text { [DD de Emanuel, p. } 35] \\
\text { O automóvel patinou na massa de areia, deu-se a uns ziguezagues perigo- } \\
\text { sos, mas Emanuel firmou-se bem ao volante. } \\
\text { - Quer vossemecê que eu fale com ela? }\end{array}$ & Retorquir \\
\hline $\begin{array}{l}\text { [DD do organizador da festa de Grudemil, p. 47] } \\
\text { O homem segurou familiarmente o braço de Emanuel, e para a rapariga: } \\
\text { - Sandra, minha amiga, bem vês, vais fazer um favor à organização: condu- } \\
\text { zes aqui o professor à tenda dos ranchos. Já vamos atrasados, bem vês. É } \\
\text { para começar às cinco, não é, professor? }\end{array}$ & Rogar \\
\hline $\begin{array}{l}\text { [DD de Sandra, p. 47] } \\
\text { Sandra parou, deixou que o associativo bigodudo lhe arrebatasse os sacos, } \\
\text { deu uma volta à pastilha elástica que tinha na boca, cruzou os braços e } \\
\text { sorriu para Emanuel: } \\
\text { - 'bora! }\end{array}$ & Convidar \\
\hline $\begin{array}{l}\text { [DD de Januário, p. 60] } \\
\text { O homem avançava para ele: } \\
\text { - Anda cá, meu cabrão, que eu vou-te mostrar o que faço aos batoteiros - } \\
\text { passou pela mesa e agarrou num candelabro. (p. 60) }\end{array}$ & Vociferar \\
\hline $\begin{array}{l}\text { [DD de Maria das Dores, p. 63] } \\
\text { Nem assim o coronel, todo torto e quase a pé-coxinho, deixou de se levan- } \\
\text { tar, gemendo, para ir procurar a } U z i \text { no armário e trazê-la para o aconchego } \\
\text { da almofada. «Você nem doente larga essa porra. Parece que casou com a } \\
\text { puta da metralhadora, ou o caraças. Ao menos se amandasse um tiro nos } \\
\text { cornos acabavam-se-lhe as chatices.» }\end{array}$ & Admoestar \\
\hline $\begin{array}{l}\text { [DD de Maria das Dores, p. } 68 \text { ] } \\
\text { Maria das Dores riu: } \\
\text { - Mas é amoroso... e para além de encontrar a pu... ou melhor, a mer... } \\
\text { quer dizer, a... água, que outros talentos tem? }\end{array}$ & Titubear \\
\hline $\begin{array}{l}\text { [DD de Angelina, p. 110] } \\
\text { - O quê? Parece que é parvo, o raio do moço! - E a rapariga, pisando o pé } \\
\text { de Emanuel, calcou o acelerador com força. }\end{array}$ & Objetar \\
\hline $\begin{array}{l}\text { [DD de Felismina, p. 130] } \\
\text { Felismina estava desconsolada: } \\
\text { - Era eu moça pequena, e o lavrador do Monte dos Chocalhos encontrou } \\
\text { um pote dos mouros que havia debaixo duma oliveira e aquilo eram só } \\
\text { libras de ouro a correr. }\end{array}$ & Lamuriar-se \\
\hline
\end{tabular}

323 Proponho apenas um exemplo de verbo no Infinitivo para cada um dos exercícios. Em contexto de aula, todas as propostas dos alunos seriam analisadas e aceites, se viáveis. A indicação das páginas de cada transcrição tem também como objectivo permitir a releitura contextualizada de cada um dos excertos. 


\begin{tabular}{|l|c|}
\hline \multicolumn{1}{|c|}{ Excerto do romance } & \multicolumn{1}{|c|}{$\begin{array}{c}\text { Reescrita do } \\
\text { excerto } 323\end{array}$} \\
\hline $\begin{array}{l}\text { [DD de Bernardes, p. 143] } \\
\text { - Olhe, Maria das Dores. Tomáramos nós! } \\
\text { Fechou a luz e voltou-se para o outro lado. }\end{array}$ & Lamentar \\
\hline $\begin{array}{l}\text { [DD de Neusa, p. 158] } \\
\text { E a rapariga que ia sentada ao lado de Nelson, nova namorada em folha: } \\
\text { - Eu queria é que esta noite nenhum de vocês ressonasse, senão amanhã } \\
\text { não estou em condições de guiar e alombam os dois sozinhos com a con- } \\
\text { dução. }\end{array}$ & Enfatizar \\
\hline $\begin{array}{l}\text { [DD de Nelson, p. 159] } \\
\text { - Tudo preto é que eu não concordo - impôs-se Nelson. Um gajo vem aqui } \\
\text { deixar o tag, porreiro, tudo bem, agora borrar a merda da placa de preto é } \\
\text { que, francamente, pá. }\end{array}$ & Retrucar \\
\hline $\begin{array}{l}\text { [DD de Tiago, p. 164] } \\
\text { Tiago fez-se modesto: } \\
\text { - Ora, isto comparado com aquela tua ideia da instalação toda feita de } \\
\text { patas de coelho e uma pipa vermelha lá dentro... - abanou a cabeça por } \\
\text { não encontrar palavras. }\end{array}$ & Relativizar \\
\hline
\end{tabular}

B.

\begin{tabular}{|l|l|}
\hline «entoar loas» (p. 32) & louvar \\
\hline «a prestar consolação» (p. 34) & consolar \\
\hline «está a produzir o seguinte [...] discurso» (p. 73) & a discursar \\
\hline «olhou para mim [...] numa imploração» (p. 93) & implorou \\
\hline «Foi fazendo conversa» (p. 94) & Foi conversando \\
\hline «vinha com uma teoria» (p. 147) & teorizou \\
\hline «produziram opiniões» (p. 207) & opinaram \\
\hline
\end{tabular}


(Página deixada propositadamente em branco) 
Série Investigação

Imprensa da Universidade de Coimbra

\section{Coimbra University Press}

2014

- $\mathbf{U}$

C •

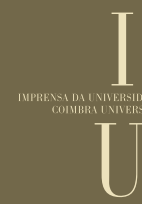

